\title{
Alojzy Z. Nowak
}

\section{POLSKIE DYLEMATY ROZWOJOWE}

\section{W POSZUKIWANIU KONKURENCYJNOŚCI STRUKTURALNEJ}

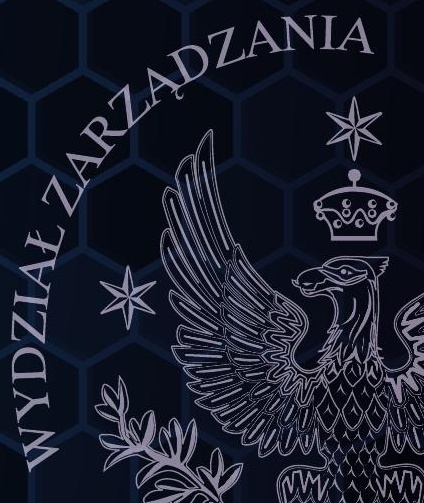




\title{
POLSKIE DYLEMATY ROZWOJOWE
}

\author{
W poszukiwaniu \\ konkurencyjności \\ strukturalnej
}


Alojzy Z. Nowak

\section{POLSKIE DYLEMATY ROZWOJOWE \\ W poszukiwaniu
konkurencyjności strukturalnej}

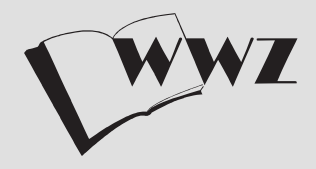

Wydawnictwo Naukowe Wydziału Zarządzania Uniwersytetu Warszawskiego

Warszawa 2020

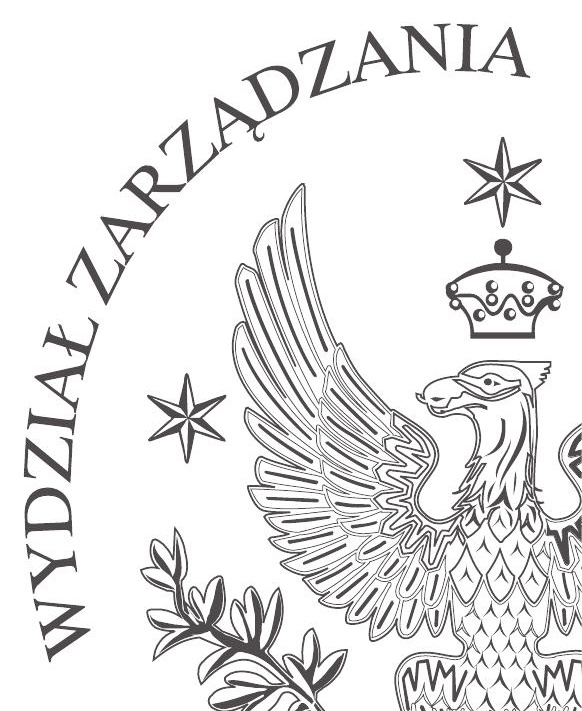


Recenzent: prof. dr hab. Zofia Wysokińska

Katedra Gospodarki Swiatowej i Integracji Europejskiej

Uniwersytet Łódzki

Redakcja: Teresa Pawlak-Lis

Projekt okładki: Agnieszka Miłaszewicz

(C) Copyright by Alojzy Z. Nowak \& Uniwersytet Warszawski, Warszawa 2020

ISBN 978-83-66282-32-2

e-ISBN 978-83-66282-33-9

DOI: 10.7172/978-83-66282-33-9.wwz.7

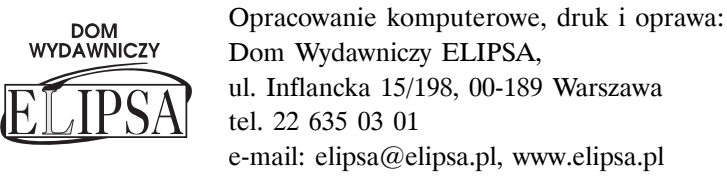


Pamięci Profesora Kazimierza Rycia, wybitnego ekonomisty, wspóttwórcy Wydziatu Zarzadzania Uniwersytetu Warszawskiego, madrego i pogodnego cztowieka, życzliwego Kolegi i Przyjaciela. 



\section{Spis treści}

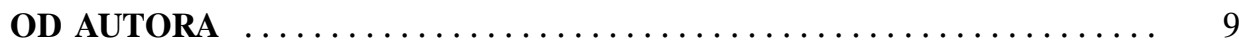

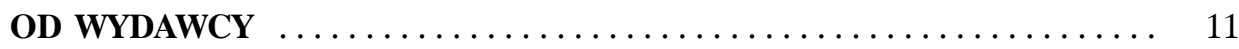

\section{Część I}

WOBEC NOWYCH WYZWAŃ GLOBALIZACJI $\ldots \ldots \ldots \ldots \ldots \ldots \ldots \ldots$

\section{Rozdzial 1.}

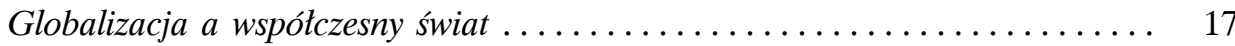

Rozdzial 2.

Przyczyny ekonomicznej i spotecznej kontrrewolucji antyliberalnej ......... 32

Rozdzial 3.

Wyzwania $w$ czasie i po pandemii Covid-19. Kapitalizm do korekty ........ 43

Rozdzial 4.

Co dla polityki przemystowej wynika $z$ trylematu Rodrika ............ 53

\section{Rozdzial 5.}

Zagadnienia ryzyka na międzynarodowych rynkach finansowych ........ 69

Rozdzial 6.

Экономическая политика после кризиса

\section{Część II}

POLSKIE DYLEMATY ROZWOJOWE

\section{Rozdzial 7.}

Strategia na rzecz Odpowiedzialnego Rozwoju dla polskiej gospodarki 


\section{Rozdzial 8.}

Nowa Ekonomia Strukturalna z polskiej perspektywy ............... 130

\section{Rozdzial 9.}

Kontrola kapitału przeciw putapce średniego dochodu ................ 140

Rozdział 10.

Profil ryzyko-dochód funduszy inwestycyjnych matych i średnich spótek ..... 151

\section{Rozdzial 11.}

Kadry stoja za sukcesem polskiej bankowości

(fragmenty wywiadu pt. Czy roboty zastapia finansistów w bankach?) . .. 171 


\section{Od Autora}

Chciałbym z okazji tej publikacji wspomnieć znakomitego ekonomistę, wieloletniego Kolegę i Przyjaciela z Wydziału Zarządzania Uniwersytetu Warszawskiego, niestety nie żyjącego już, Profesora Kazimierza Rycia, który pozwolił mi, a jestem przekonany, że wielu osobom na Wydziale, lepiej zrozumieć i poznać reguły i zasady makro i mikroekonomii, meandry gospodarki globalnej, mechanizmy polityki sektorowej, czy rolę państwa w gospodarce i z pasją oraz zaangażowaniem zarazić nas do analiz i badań w tych kluczowych dziedzinach współczesnej ekonomii.

Zawsze podkreślałem, iż w seminariach prowadzonych przez lub przy współudziale Profesora Rycia liczyła się przede wszystkim rzetelność badawcza, otwartość poznawcza oraz sposób argumentacji. Tymi podstawami wybitnego naukowca zarażał nas nieustannie, i jestem przekonany, że z dobrymi rezultatami. W efekcie powstawały prace, które były bądź dziełami Profesora, bądź monografiami wspólnymi. Dla mnie uosabiał On zawsze Człowieka Uniwersytetu, uczelni tworzącej, otwartej, tolerancyjnej, szanującej różne poglądy i preferencje badawcze.

Nigdy nie był także Profesor Ryć zazdrosny o sukcesy naukowe swoich współpracowników czy wychowanków, a wręcz przeciwnie cieszył się z ich osiągnięć, niejednokrotnie również wspierał je swoim autorytetem. Doświadczyłem tego wielokrotnie. Obecna publikacja w znacznej mierze nawiązuje do naszych wspólnych badań i zainteresowań ekonomiczno-społecznych. 



\section{Od wydawcy}

Idea niniejszej książki powstała wokół refleksji nad nowymi, bardzo aktualnymi, czasami dramatycznymi wyzwaniami i zagrożeniami, pojawiającymi się w szczególności w końcu ostatniej dekady XXI wieku. Obecnie, większość polskich ekonomistów zapewne zgodziłaby się z Autorem, iż epidemia koronawirusa stanowi dla całego świata nie tylko problem medyczny. Skala zagrożenia, które wywołał wirus sprawia, że stał się nie tylko wyzwaniem o charakterze medycznym, ale problemem politycznym, gospodarczym i społecznym w skali całego globu.

Autor w wielu prezentowanych rozdziałach tej publikacji próbuje odpowiedzieć na pytanie: dlaczego - biorąc nawet pod uwagę obecny stan pandemiczny - koronawirus tak dramatycznie paraliżuje wszystkie kraje nim dotknięte, nawet te najbogatsze. Jest przekonany, iż warto kontynuować analizę w kwestii zasadniczej i rozważyć, czy być może jest coś nie tak z wolnorynkową gospodarką kapitalistyczną i systemami ochrony zdrowia oraz opieki społecznej w większości rozwiniętych krajach świata. Nie chodzi o podważenie także wielu zalet gospodarki rynkowej. Autorowi tej książki raczej idzie o powrót do głębszej i pozbawionej ideologicznych stereotypów roli i miejsca państwa w kreowaniu polityki gospodarczej i społecznej. W szczególności, kiedy rola państwa w gospodarce i model społeczeństwa XXI wieku zasadniczo zostały oparte na czterech filarach globalizacji gospodarczej: prywatyzacji, liberalizacji, deregulacji i integracji.

Jak się wydaje, Autorowi tej publikacji bliski jest pogląd, iż rola państwa w gospodarce i model społeczeństwa XXI wieku nie może wyłącznie zależeć od dominujących tendencji na rynkach światowych. Jak podkreśla wzrost nierówności społecznych jest w dużej mierze wynikiem działania samonakręcającej się finansyzacji gospodarki światowej. Dzisiaj to rozwinięta społeczna gospodarka rynkowa wydaje się być najbardziej pożądanym modelem rozwojowym. Choć z drugiej strony określanie celów strategicznych państwa, czy ich realizacja nie może całkowicie abstrahować od realiów gospodarki światowej. Nie idzie więc o to, aby rachunek ekonomiczny odstawić na bok, a kategorię zysku wyrzucić na śmietnik historii gospodarczej. Natomiast nie można zignorować konsekwencji i doświadczeń wynikających także z obecnej pandemii. 
W jednym z kluczowych rozdziałów publikacji Wyzwania w czasie $i$ po pandemii Covid-19. Kapitalizm do korekty, pojawia się konkluzja Autora: „W kwestiach systemowych, obecny model kapitalizmu jest daleki od ideału, trzeba go zrewidować i naprawić. Może być i cudowny, i okropny. Potrzebuje więcej etyki, uczciwych zasad i dobrych praktyk. Jeżeli chcemy go poprawić, to musimy rozwijać firmy oparte na wartościach. A w rozwiązaniach systemowych powinniśmy skorzystać w większym stopniu z dorobku zarówno Johna Maynarda Keynesa, jak i Josepha Aloisa Schumpetera”.

Po raz pierwszy w historii, Polska ma taki sam lub bardzo podobny problem rozwojowy jak duża grupa wysoko rozwiniętych krajów Zachodu. Jak, i za sprawą jakiej polityki ekonomicznej i społecznej przezwyciężyć wielorakie negatywne skutki pandemii, między innymi ograniczenie produkcji i konsumpcji, załamanie aktywności społecznej i gospodarczej i jak spowodować, aby możliwie najszybciej powrócić na ścieżkę odbudowy własnego potencjału gospodarczego i społecznego. Ma to istotne konsekwencje dla perspektyw dalszego rozwoju ekonomicznego, społecznego i cywilizacyjnego naszego kraju - doganiania rozwiniętych krajów Zachodu. W tej kwestii poglądy Autora publikacji są wyraziste, będące rezultatem Jego badań naukowych i analiz, podjętych w szczególności w drugiej dekadzie XXI wieku.

Polska gospodarka w ostatniej dekadzie rozwija się dynamicznie na tle całej Unii Europejskiej. Istnieją dobre perspektywy dla dalszego szybkiego i stabilnego jej rozwoju, bowiem coraz lepsze efekty przynosi Strategia na rzecz Odpowiedzialnego Rozwoju, realizowana przez polski rząd. Co może okazać się decydujące dla sukcesu modernizacyjnego Polski? Szansę na ten sukces należy upatrywać przede wszystkim w innowacyjności polskiej gospodarki. Profesor Alojzy Z. Nowak pisze, iż rozwój gospodarczy powinien dokonywać się raczej poprzez wchodzenie na wyższe poziomy w łańcuchu tworzenia wartości dodanej produktu oraz dzięki szybszej zamianie struktury gospodarki, w której coraz większy udział miałyby sektory o większej produktywności i unikalności. $\mathrm{Z}$ tego punktu widzenia Autor publikacji przywiązuje dużą wagę do kontynuacji polityki strukturalnej w polskiej gospodarce. I w ogóle znaczenia aktywnej polityki strukturalnej w modelu rozwojowym dla Polski.

Te poglądy bliskie są Autorowi koncepcji teoretycznej Nowej Ekonomii Strukturalnej, profesorowi Uniwersytetu Pekińskiego, w latach 2008-2012 głównemu ekonomiście i wiceprezesowi Banku Światowego, Justinowi Yifu Linowi. Od roku 2017 Wydział Zarządzania Uniwersytetu Warszawskiego, w okresie kiedy Profesor Alojzy Z. Nowak pełnił funkcję dziekana, podjął współpracę naukową i publikacyjną z Profesorem Linem, czego rezultatem były dwie monografie, wydane przez Wydawnictwo Naukowe Wydziału Zarządzania Uniwersytetu Warszawskiego: „New Structural Economics for Less Advanced Countries” i „Nowa polityka strukturalna $w$ warunkach otwartej gospodarki rynkowej”. 
Niniejsza publikacja jest aktualizacją i rozwinięciem wielu analiz prezentowanych we wcześniejszych publikacjach Autora. Teksty większości rozdziałów (w trzech przypadkach $\mathrm{w}$ formie współautorstwa) były również publikowane w różnych wydawnictwach, zarówno książkowych, jak i na użytek czasopism polskich i zagranicznych. Wielką zaletą i wartością tej książki pt. Polskie dylematy rozwojowe. W poszukiwaniu konkurencyjności strukturalnej jest integralny charakter refleksji naukowej Autora oraz Jego wyraziste poglądy na tematy nurtujące dziś środowisko ekonomistów i badaczy nauk społecznych. Wydaje się, że najnowsza książka Autora, obecnie Rektora Uniwersytetu Warszawskiego, powinna stanowić dobrą sposobność do dyskusji naukowej i rozważań na tematy tak bardzo nurtujące, zresztą nie tylko, środowiska naukowe. 

Część I

\section{Wobec nowych wyzwań globalizacji}





\title{
Rozdział 1 \\ Globalizacja a współczesny świat
}

\begin{abstract}
Streszczenie
Artykuł podejmuje zasadnicze kwestie związane z obecnym etapem globalizacji. Analizuje między innymi główne przyczyny ekonomicznej i społecznej kontrrewolucji antyliberalnej oraz podkreśla jej wpływ na nowo rodzący się kształt światowego ładu gospodarczego. Finansyzacja gospodarki światowej, będąca w dużej mierze rezultatem niekontrolowanych dostatecznie rynków finansowych, a także bardzo dotkliwe dla społeczeństw działania spekulacyjne i narastające rozwarstwienie społeczne przyczyniły się między innymi do zakwestionowania modelu rozwojowego opartego głównie na rynkach, bez należytego wsparcia regulacyjnego i kontrolnego ze strony państwa. Skoro istnieje coraz powszechniejsze przekonanie, że na obecnym etapie rozwoju gospodarczego globalizacja oparta wyłącznie na neoliberalnych zasadach powinna być gruntownie przemyślana, to w jakim kierunku powinny nastąpić korekty lub zmiany obecnego stanu rzeczy.
\end{abstract}

Słowa kluczowe: globalne dylematy, modele rozwojowe, konsensus waszyngtoński, finansyzacja gospodarki, innowacje, Unia Europejska.

\section{Globalization and the Present World}

\section{Summary}

The article deals with basic issues related to the current stage of globalization. Among others, it analyzes main causes of the economic and social anti-liberal counter-revolution, and emphasizes its influence on the newly emerging shape of the world economic order. The financialisation of the world economy, which is largely the result of insufficiently and uncontrolled financial markets, as well as speculative activities, which are still very severe for societies and for social stratification put into question the predominantly market-driven development model without proper regulatory and control support from the state. There is

Tekst ten jest zaktualizowaną i rozszerzoną wersją artykułu pt. Wspótczesny świat $w$ erze turbulencji. W: J. Bogdanienko, W. Piotrowski (red.). (2013). Zarzqdzanie: tradycja i nowoczesność. Warszawa: PWE. 
a growing coviction that at the present stage of economic development, globalization based solely on neo-liberal principles should be carefully thought out, and then to consider in what direction should the current state of globalization be corrected or changed.

Keywords: global dilemmas, development models, washington consensus, financialisation of the economy, innovations, European Union.

\subsection{Globalne dylematy XXI wieku}

Pytanie, które należy zadać brzmi: czym na początku XXI wieku jest globalizacja? W zależności od specjalizacji konkretnego badacza definicja tego pojęcia jest zróżnicowania. Inaczej jest definiowana przez socjologów, inaczej przez środowiska politologów, a jeszcze inaczej przez ekonomistów. Przyjmijmy więc zróżnicowane definicje w literaturze przedmiotu za Johnem Ravenhillem (2005, s. 45). Zatem globalizacja to:

- intensyfikacja relacji społecznych w wymiarze światowym (Anthony Giddens);

- integracja światowej gospodarki (Robert Gilpin);

- deterytoryzacja lub wzrost ponadnarodowych relacji między ludźmi (Jan Aart Scholte);

- globalna gospodarka, w której narodowe gospodarki, a więc narodowe strategie gospodarcze i zarządzania, tracą w dużej mierze na znaczeniu (Paul Hirst, Grahame Thompson).

Te ogólne definicje, opisujące pojęcie globalizacji, nie są obecnie - jak się wydaje - wystarczające, zwłaszcza w odniesieniu do takich obszarów ekonomii, jak: nowoczesne koncepcje organizacji i metody zarządzania, a w szczególności wpływu wielkiego rozwoju najnowszych technologii na działania rynku w skali globalnej, jak skutki megatrendów w gospodarce globalnej na długofalowe funkcjonowanie rynków, w tym rynków finansowych (Krugman, 2008).

Jednak pytania, jakie przynosi globalizacja mają wymiar bardziej ogólny, ponieważ dotyczą kwestii tak zasadniczych, jak (zob. Nowak, 2013, s. 46):

- rola państwa w gospodarce i model społeczeństwa XXI wieku;

- wartości i cele, które utrzymują społeczeństwa jako całość i integrują wspólnoty.

Te zasadnicze wartości opierają się na wyborze takich rozwiązań, które odnoszą się między innymi do:

- poczucia sprawiedliwości (mniejsze lub większe rozwarstwienie społeczne);

- systemów wartości, stylu życia, dylematów wobec różnego rodzaju mniejszości (etnicznych, zjawisk genderowych itd.);

- suwerenności jednostki, narodów i państw. 
Chodzi również o poziom świadomościowy, ponieważ odpowiedź na pytanie: gdzie i jak daleko posunęła się globalizacja? - zależy w części od tego, czego się od niej oczekuje. Wizje globalizacji współokreślają jej realny kształt, ponieważ globalizacja jest właśnie częściowo konstruowana według wizji, stanowiąc wypadkową konfrontacji sił „losu” i sił „wyboru”, sama nie będąc, ani tylko „losem”, zdeterminowanym niezależnymi od nas czynnikami, ani tylko rezultatem naszych decyzji - „wyborem” (Morawski, 2004, s. 22).

Jeśli chodzi o wybór w procesie globalizacji, to dotyczy on wielu pytań i dylematów, odnoszących się choćby do modelu i granic modernizacji. Jednak można przyjąć, że modernizacja stwarza szansę na (Nowak, 2013, s. 47):

- wzrost dobrobytu jednostek i narodów;

- wzmocnienie prestiżu i pozycji państwa, a także społeczności lokalnych oraz rodziny;

- wzbogacanie wartości duchowych i intelektualnych.

Jednak najwyraźniej te szanse są inaczej rozumiane i interpretowane ze względu na zasadnicze zróżnicowanie ekonomiczne i kulturowe narodów i państw. Dlatego poszerzanie, a niekiedy narzucanie systemu wartości i postaw typowych dla świata Zachodu, takich jak: konsumpcjonizm, wiara w samoczynny, pozytywny skutek rynku, czy prawa człowieka, spotkały się z krytyką, a nierzadko odrzuceniem modelu modernizacji, typowego dla głównych aktorów globalnego rynku, takich jak Stany Zjednoczone, czy państwa europejskie.

Można więc mówić, że poza głównym nurtem, a przynajmniej w pewnej opozycji do dominującego modelu modernizacji, znalazły się (Nowak, 2013):

- Świat islamu, który przyjął ograniczone dobrodziejstwa gospodarki globalnej, ale wyraźnie zaznacza swoją odrębność kulturową. Poprzez nagromadzone zasoby kapitałów finansowych wzmacnia realne światowe procesy gospodarcze, ale zarazem może stać się potencjalnym czynnikiem regionalnej destabilizacji ekonomicznej i politycznej.

- Świat południa globu, w szczególności świat krajów słabo rozwiniętych, głównie afrykańskich, wykluczonych w dużej mierze z pożytków i korzyści, jakie niosą ze sobą procesy globalizacji.

- Świat cywilizacji chińskiej. Specyfika przypadku Chin kontynentalnych i innych państw azjatyckich, w których wpływ kulturowy Państwa Środka jest oczywisty, polega na tym, że stały się one jednym z największych beneficjentów globalizacji, a zarazem pozostają, głównie w przypadku Chin, odrębnym wzorcem rozwojowym. Mamy bowiem tutaj - jak się wydaje - przykład udanej (w sensie ekonomicznym) modernizacji antyliberalnej, a więc modelu, opierającego się głównie nie tyle na sprawdzonych wzorach, zaczerpniętych z doświadczeń wysoko rozwiniętych państw Zachodu, ile między innymi na dziedzictwie kulturowym, wynikającym z filozofii Konfucjusza. 
Osiągnięcia Chin, a zarazem największy po II wojnie światowej globalny kryzys finansowy i jego kulisy, a także wychodzenie $\mathrm{z}$ epidemii koronawirusa, skłaniają wielu ekonomistów i politologów do daleko idącej, ale nie wyłącznie futurologicznej konstatacji, że oto jesteśmy świadkami kresu dominacji cywilizacji zachodniej (Ferguson, 2010).

Laureat Nagrody Nobla w dziedzinie ekonomii Joseph E. Stiglitz idzie jeszcze dalej i twierdzi, że przede wszystkim światowy kryzys gospodarczy w pierwszej dekadzie XXI w., spowodowany w dużej mierze przez zachowanie Stanów Zjednoczonych Ameryki, wyrządził więcej szkód podstawowym wartościom świata cywilizacji zachodniej i gospodarce niż jakikolwiek system totalitarny. Pogląd ten dalece kontrowersyjny, w formie bardziej oględnej jest często formułowany przez środowiska naukowe nie tylko w Stanach Zjednoczonych.

Jednak istota słabnięcia pozycji cywilizacji zachodniej nie jest wyłącznie związana z turbulencjami w globalnej gospodarce, spowodowanymi przez koronawirusa, czy wcześniej światowym kryzysem finansowym i rolą, jaką odegrały w nim Stany Zjednoczone. Wiąże się to także z bardziej ogólnymi tendencjami występującymi w wielu najbardziej rozwiniętych krajach świata, ale jednocześnie z rosnącym znaczeniem Chin, jak i wielu państw Azji. Tak więc przyczyny tego stanu rzeczy wydają się być znacznie poważniejsze (Nowak, 2013, s. 49).

- Słabnie konkurencyjność gospodarek głównych państw Zachodu. W coraz większym stopniu szala w tej dziedzinie przechyla się na korzyść państw całej strefy azjatyckiej. I choć nadal gospodarka amerykańska oraz niektóre gospodarki państw strefy euro, wykazują się wysoką innowacyjnością i zdolnością adaptacyjną, to jednak ich przewaga w tych dziedzinach zdecydowanie maleje. Rewolucja w wydobywaniu gazu łupkowego i osiągnięcia w tym zakresie dokonane przez Stany Zjednoczone, czy nadal amerykański potencjał innowacyjny poprawiły nieco pozycję konkurencyjną USA, ale to nie oznacza, że ta tendencja utrzyma się w przyszłości.

Pandemia koronawirusa dotknęła w bardzo dużym stopniu bogate i dobrze rozwinięte kraje, takie jak Włochy, Hiszpania, Wielka Brytania czy USA. To w tych krajach do niedawna wydawało się znaleziono i praktykowano fundamenty i reguły rozwojowe, gwarantujące realizację aspiracji i potrzeb społecznych większości obywateli. A jednak mamy w tym względzie teraz uzasadnione wątpliwości, czy rzeczywiście tak jest.

- Uszczerbku doznaje dotychczasowy etos społeczeństwa konsumpcyjnego, oparty na trzech filarach:

- intensywnej pracy,

- wyższej stopie oszczędności,

- trwałej akumulacji kapitału. 
To także dzięki temu etosowi zostały zbudowane zręby wysoko rozwiniętych państw kapitalistycznych, o wysokim poziomie dobrobytu i opieki społecznej (Nowak, 2013).

- Etyka pracy przestaje być bezwzględnym priorytetem. Czynnikiem, który destrukcyjnie wpływa na ten stan rzeczy jest między innymi rosnące przekonanie o coraz mniejszym związku zachodzącym pomiędzy sensem dodatkowego wysiłku a stosowną gratyfikacją finansową z tego tytułu. Niezwykle szkodliwy wpływ na świadomość społeczną w zakresie etyki i moralności miały i nadal mają między innymi wynaturzenia na rynkach finansowych. W coraz większym stopniu rośnie przekonanie, że dochodów z pracy nie można w najmniejszym stopniu porównać z zyskami na giełdzie, czy poprzez różnego rodzaju zachowania spekulacyjne (Nowak, 2013).

- Pojawia się na masową skalę zjawisko cyberterroryzmu. Polega on głównie na posługiwaniu się zdobyczami technologii informacyjnej w celu wyrządzenia szkody z pobudek politycznych, ideologicznych oraz coraz częściej ekonomicznych państwu, jego infrastrukturze technologicznej, szczególnie tej, mającej istotne znaczenie dla gospodarki.

- Następuje zarazem niebezpieczny kryzys autorytetu władz i praworządności w wielu krajach cywilizacji zachodniej. Dotychczas powszechnie uznawano, że demokracja liberalna, państwo prawa oraz społeczeństwo obywatelskie, to najlepsze lekarstwa na pokusę destabilizacji politycznej. Jednak w szczególności ostatni kryzys finansowy, bardzo demoralizujące przykłady bezradności, a czasami współodpowiedzialności władz politycznych za stan państwa i najważniejszych jego instytucji, także instytucji, które wymknęły się spod kontroli, sprawiły, że pojawiły się na dużą skalę protesty społeczne kwestionujące autorytet władz i podstawy ładu prawnego (Nowak, 2013, s. 50).

\subsection{Nowe wzorce rozwojowe - koniec konsensusu waszyngtońskiego?}

Coraz większe grono ekonomistów uważa, że wiele problemów, które pojawiły się w skali globalnej powinno doprowadzić do poszukania nowych rozwiązań oraz nowego ładu i porządku ekonomicznego, opartego już nie tylko na Stanach Zjednoczonych czy Unii Europejskiej, ale także na Japonii, jak również na interesach i sile nowych potęg gospodarczych takich, jak między innymi: Chinach, Indiach, Brazylii, Meksyku, a więc na tzw. gospodarkach wschodzących. Zachodzące coraz bardziej poważne, inne zmiany systemowe miałyby odwrócić dotychczasowe wzorce rozwojowe w światowej gospodarce.

Przez wiele ostatnich dekad $w$ teorii ekonomii dominował konsensus waszyngtoński. Wyrastał on nie tylko z naukowych badań, ale także z realnych 
tendencji, występujących $\mathrm{w}$ procesie globalizacji. Te megatrendy $\mathrm{w}$ gospodarce światowej to przede wszystkim (Nowak, 2013):

\section{Deregulacja.}

2. Liberalizacja.

3. Prywatyzacja.

4. Integracja.

Te cztery główne tendencje występujące w gospodarce światowej, czyli: deregulacja, liberalizacja, prywatyzacja i integracja stały się zasadniczym kanonem polityki ekonomicznej wielu państw.

W tej kwestii do niedawna dominował wspomniany wcześniej tzw. konsensus waszyngtoński. Twórcą tego pojęcia był John Williamson, dyrektor Instytutu Gospodarki Światowej (Institute for International Economics) w Waszyngtonie. Te cztery mega trendy miały w założeniu sprzyjać przede wszystkim (Nowak, 2013):

1. Utrzymaniu dyscypliny finansowej, tak aby deficyt budżetowy był stosunkowo niewielki lub najlepiej zrównoważony.

2. Przeprowadzeniu reformy podatkowej, tak, aby stała się również istotnym bodźcem do rozwoju ekonomicznego.

3. Liberalizacji finansowej (której ostatecznym celem jest określanie stóp procentowych przez rynek).

4. Ujednoliceniu kursów walut, przynajmniej dla transakcji handlowych oraz ustaleniu ich na poziomie umożliwiającym rozwój nowych sektorów gospodarki, aby zapewnić jej trwałą konkurencyjność.

5. Zliberalizowaniu zasad handlu światowego.

6. Zniesieniu przeszkód dla bezpośrednich inwestycji zagranicznych, tak aby firmy zagraniczne konkurowały z krajowymi na równych zasadach.

7. Przeprowadzeniu prywatyzacji i w węższym zakresie - komercjalizacji.

8. Dokonaniu deregulacji, usuwającej przepisy blokujące wejście na rynek i ograniczające konkurencję z powodów innych niż bezpieczeństwo.

9. Ograniczeniu nadzoru nad instytucjami finansowymi i rynkami finansowymi.

10. Ochronie praw własności przez system prawny tak skonstruowany, aby posiadanie nie wiązało się z nadmiernymi kosztami.

Te podstawowe wytyczne dla polityki gospodarczej z czasem ulegały pewnym modyfikacjom, jednak ich główny trzon nie podlegał zmianom. Stały się one głównym wzorcem rozwojowym dla wielu krajów. Przyniosły bowiem w licznych przypadkach pozytywne rezultaty. Były ważnym składnikiem transformacji systemowej, w szczególności w gospodarkach rozwijających się lub negatywnie doświadczonych systemem centralnego planisty.

Momentem przełomowym weryfikującym ustalenia tzw. konsensusu waszyngtońskiego stał się niespodziewany co do skali i rozmiarów światowy kryzys finansowy w latach 2007-2009. Jego negatywne skutki miały wielki wpływ na gospodarkę światową. Pewne założenia teoretyczne teorii ekonomicznych, 
opartych na wierze w samoczynne mechanizmy naprawcze wolnego rynku, nie sprawdziły się. System, pozbawiony mechanizmów regulacji, zaczął ,produkować" różnego rodzaju wynaturzenia. Szczególnie dotkliwe dla gospodarki, ale także dla zwykłych obywateli, okazały się błędy i wypaczenia, które pojawiły się na rynkach finansowych.

Nowe instrumenty finansowe wytworzone na rynku amerykańskich nieruchomości (subprime) okazały się gigantyczną bańką spekulacyjną. To one zapoczątkowały narastanie kryzysu finansowego w Stanach Zjednoczonych. Z kolei deregulacja w systemie bankowym spowodowała, poza pozytywnymi rezultatami, także wielce negatywne skutki. Reakcją banków na poszukiwanie przez kapitał aktywów było rozbudowywanie niebankowych obszarów działalności bankowości inwestycyjnej i usług zarządzania aktywami (Dewatripont, Rochet, Tirole i Tribe, 2010, s. 76). Te nowe obszary działalności sektora bankowego, nastawione na szybki i duży zysk, przyczyniły się do wyprodukowania tzw. toksycznych aktywów, które doprowadziły w Stanach Zjednoczonych niektóre wielkie banki, instytucje ubezpieczeniowe i firmy zarządzające kapitałem do bankructwa. Kluczowy w Stanach Zjednoczonych rynek nieruchomości ucierpiał najbardziej. Koszt tych zawirowań ponieśli głównie podatnicy amerykańscy (Nowak, 2013, s. 54).

\subsection{Globalizacja a finansyzacja gospodarki światowej}

Gdybyśmy popatrzyli na obecny świat z punktu widzenia ekonomicznego i społecznego, to można dostrzec nade wszystko ogromną dyferencjację w kształtowaniu dochodów. Potwierdzają to wyniki badań przeprowadzonych w Akademii Biznesu Międzynarodowego na Uniwersytecie Harvarda. Tendencję tę najlepiej obrazuje rysunek 1.1 .

Rysunek 1.1. Dywersyfikacja w kształtowaniu dochodów

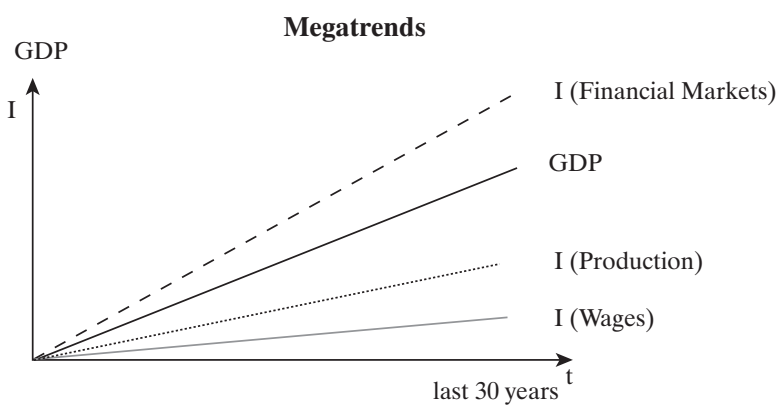

Źródło: Na podstawie badań przeprowadzonych w Akademii Biznesu Międzynarodowego Uniwersytetu Harvarda w 2010 roku. 
Produkt krajowy brutto jest takim punktem odniesienia w okresie ostatnich 30 lat. Zauważa się wyraźnie, że w tym okresie powstawały duże różnice (disparity) pomiędzy dochodami $\mathrm{z}$ operacji finansowych a dochodami $\mathrm{z}$ produkcji, a także z pracy. Znacznie powyżej tempa wzrostu gospodarczego produktu krajowego brutto (PKB) kształtowały się dochody $\mathrm{z}$ operacji finansowych na rynkach finansowych, czyli, inaczej mówiąc, ze sprzedaży papierów wartościowych, które były w szczególności tworzone po rozpadzie systemu walutowego z Bretton Woods w 1972 roku.

Joseph E. Stiglitz liczbę różnorodnych instrumentów finansowych, funkcjonujących w gospodarce światowej, oceniał na kilkaset, a nawet do półtora tysiąca. W oparciu o dane Deutsche Bundesbanku, czy na podstawie prestiżowego dziennika brytyjskiego Financial Times, Joseph E. Stiglitz stwierdzał, że ilość instrumentów finansowych, będących w obiegu, czyli poza systemem bankowym, a więc znajdujących się w przedsiębiorstwach i gospodarstwach domowych, była znacznie wyższa niż wynikałoby to z potrzeb wielkości światowego produktu krajowego brutto. Relacja instrumentów finansowych, będących do dyspozycji podmiotów gospodarczych w stosunku do PKB, jest właśnie przyczyną finansyzacji gospodarki światowej. Ta tendencja jeszcze bardziej pogłębiła się pod koniec drugiej dekady XXI wieku.

Co wynika także z obecnych doświadczeń i wiedzy na temat przebiegu ogólnoświatowej pandemii koronawirusa i ogólnoświatowego kryzysu, który ona wywołuje? Z punktu widzenia społeczno-gospodarczego nabieramy przekonania, iż nie da się zbudować nowoczesnej, ale i bardziej stabilnej gospodarki XXI wieku bez próby uwzględnienia zmieniających się warunków, aspiracji i uzasadnionych, nowych potrzeb społecznych. Po prostu nie można zignorować skutków ekonomicznych, ale może w jeszcze większym stopniu społecznych, które wywołuje pandemia koronawirusa. Są to zresztą obszary spraw mocno ze sobą powiązane.

\subsection{Globalizacja a "nowa gospodarka”}

Globalizacja, obok liberalizacji przepływów kapitałowych, jest jednym z głównych procesów, które mają wpływ na kształtowanie się współczesnych rynków finansowych. Silne zbliżenie reguł rynku, podobieństwo wykorzystywanych instrumentów oraz występowanie globalnych aktorów wskazuje, że międzynarodowy rynek finansowy ma charakter globalny. Globalizacja rynku i liberalizacja przepływów kapitałowych oraz rozwój technologii telekomunikacyjnych spowodowały zwiększenie natężenia międzynarodowych przepływów kapitałowych oraz zmiany w horyzoncie inwestycyjnym.

Możliwe stały się szybkie i jednocześnie bardzo gwałtowne zmiany alokacji geograficznej inwestycji przez podmioty rynkowe. Dla części inwestorów zmie- 
nił się też horyzont analiz. Coraz donioślejszą rolę zaczęła odgrywać nie tyle ocena krótkoterminowa, ile zdolność reakcji na krótkoterminowe wahania, już nie tylko mierników ekonomiczno-finansowych, jak stopy procentowe, czy kurs walutowy, ale zmiany sytuacji politycznej (na przykład kryzysy rządowe). Pojawia się więc pytanie, czy procesy te nie miały wplywu na powstawanie i przebieg wcześniejszych, ale i obecnych kryzysów finansowych (Kozioł, 2004, s. 141).

$\mathrm{Na}$ to pytanie należy odpowiedzieć twierdząco. Kluczowa wątpliwość polega na tym, czy ostatnie kryzysy gospodarcze, które w dużej mierze były rezultatem światowego kryzysu finansowego, to już raczej historia. To prawda, że interwencja na szeroką skalę ostatecznych pożyczkodawców (rządów i banków centralnych) zakończyła dalszą eskalację utraty płynności finansowej przez podstawowe podmioty gospodarcze i finansowe (banki komercyjne, fundusze inwestycyjne, fundusze ubezpieczeniowe itp.), oraz że spowodowało to wzrost optymizmu w gospodarce realnej, co powinno przełożyć się na bardziej trwały wzrost gospodarczy i powolne, ale konsekwentne wychodzenie z kryzysu.

Inny punkt widzenia wszakże wskazuje, że ze względu na wielkość i różnorodność środków finansowych, a wśród nich tak zwanych aktywów toksycznych, będących wciąż w obiegu, obecny kryzys został tylko ograniczony, czy przyhamowany.

Obecnie widzimy, że tradycyjne metody wychodzenia z kryzysu podejmowane przez rządy to, z jednej strony:

- dyscyplina budżetowa oraz fiskalna;

- ograniczenia wydatków publicznych;

- podnoszenie podatków.

A z drugiej zaś:

- pobudzanie gospodarki, między innymi poprzez luzowanie fiskalne;

- powrót do „konwencjonalnej mądrości z okresu kryzysu finansowego z lat 2007-2009, zgodnie z którą polityka stóp procentowych banków centralnych sama powinna wystarczyć do utrzymania stabilności makroekonomicznej" jest niemożliwy. Obecnie sami szefowie banków centralnych przekonują rządy o korzyściach płynących ze śmielszego wykorzystywania budżetów do pobudzania wzrostu gospodarczego;

- działania interwencyjne na rzecz zwiększania konsumpcji i ograniczania bezrobocia. Jednocześnie poszukiwanie nowych sposobów powrotu do możliwie pełnego zatrudnienia staje się ponownie głównym priorytetem niektórych rządów. Tym niemniej dominuje wciąż przekonanie, iż dzisiejszy model kapitalizmu będzie jednak bardzo trudno zdemokratyzować i ucywilizować, czyli przebudować w kierunku zmniejszania nierówności społecznych, które on generuje;

- wspieranie eksportu i zachęty dla inwestorów zagranicznych i kapitału obcego. 
W okresie kryzysu obserwujemy jednak, że niektóre rządy wykraczają nieco poza działania standardowe i np. zwiększają lub nie ograniczają wydatków publicznych na obsługę potrzeb ludzi starszych, w takich dziedzinach, jak: biomedycyna, odnowa zdrowia, opieka społeczna, gdyż w rozwoju tych specjalności niektóre rządy widzą także potencjalne źródło powstawania nowych, perspektywicznych produktów, czy technologii innowacyjnych.

Nie przekreślając zasadności, czy konieczności takich poczynań w dłuższym okresie, kluczem do bardziej stabilnego rozwoju gospodarczego wydają się być systematyczne działania na rzecz podniesienia konkurencyjności i produktywności firm oraz tworzenie warunków do rozwoju nowych, innowacyjnych gałęzi i sektorów gospodarki.

Innowacje stają się więc, w szczególności w okresie kryzysu:

- siłą napędową współczesnej gospodarki;

- ważnym czynnikiem promodernizacyjnym, podnoszącym efektywność gospodarczą;

- buduja podwaliny pod trwały wzrost ekonomiczny, wzmacniają potencjał gospodarczy i,

- mają zasadniczy wpływ nie tylko na rozwój przedsiębiorstw, ale również na standardy życia konsumentów.

Dlatego rządy, stawiający na ten model rozwojowy dążą do:

- poszerzania obszaru gospodarki i usług, opartych na wiedzy;

- wdrożenia takiego systemu edukacji, w którym priorytet nadaje się kreatywności i tworzeniu nowych kompetencji;

- reformy wyższych uczelni, aby były powiązane w większym stopniu z potrzebami i wyzwaniami lokalnej i globalnej gospodarki oraz budowaniem solidnych podstaw do wyzwalania kapitału intelektualnego;

- wspierania edukacji publicznej, gdzie istotną rolę w propagowaniu postaw innowacyjnych mogą odegrać media elektroniczne, Internet oraz E-edukacja;

- tworzenia ram prawnych i instytucjonalnych dla sprawnego państwa, przyjaznego dla polityki innowacyjnej.

Złożoność, koszt oraz ryzyko, jakie pojawiają się w procesie innowacji sprawiają, że państwo staje się ważnym podmiotem (współautorem) w tworzeniu systemowych uwarunkowań, sprzyjających, powstawaniu nowych produktów i modeli biznesowych. Choć rola państwa w tych kwestiach jest niepodważalna, to jednak ostatecznie klucza do wzrostu konkurencyjności i przewagi na rynkach należy szukać w samych podmiotach gospodarczych i finansowych oraz w ich podejściu do innowacji.

Obecnie nie trudno uchwycić główne tendencje w ich polityce innowacyjnej:

1. Odchodzenie od dotychczasowego modelu kreacji polityki innowacyjnej, opartej na jednej firmie na rzecz modelu opartego na współpracy licznych firm, działających na wielu komplementarnych obszarach przedsiębiorczo- 
ści. Coraz bardziej powszechne staje się tworzenie klastrów, także ponad granicami państw nowych technologii, czy konsorcjów, których wspólpraca opiera się nie tylko na zbliżonych poziomach naukowych, czy technologicznych, ale także na lepszym rozeznaniu specyfiki danego, lokalnego rynku, również w wymiarze kulturowym.

2. Region staje się coraz częściej miejscem interakcji potrzebnych do zaistnienie procesów modernizacyjnych, a jego cechy i specyficzny potencjał sprzyja redukcji ryzyka innowacyjnego, ułatwia absorbcję różnego rodzaju wiedzy, daje możliwość interaktywnego uczenia się i wymiany doświadczeń.

3. W coraz większym stopniu małe i średnie przedsiębiorstwa (MŚP) będą osiągały znaczący udział w innowacjach, bowiem ich głównym motorem nie jest tylko poziom wydatków na badania, lecz także kreatywność i możliwość wykorzystania wysokiego poziomu rozwoju nauk ścisłych, które mogą być spożytkowane przez jednostki i stosunkowo niewielkie grupy osób. Stąd rosnące znaczenie na rynku innowacyjnych przedsiębiorstw rodzinnych. Mariana Mazzucato w książce: Przedsiębiorcze państwo. Obalić mit o relacji sektora publicznego i prywatnego na podstawie badań twierdzi, iż najsolidniejsze, dostępne dowody pokazują, jak ważne dla gospodarki są nie tyle małe firmy ile te firmy nowe, rozwijające się. Tak więc znaczenie ma nie tyle wielkość firmy, co wysoki wzrost odnotowany przez nią i że najlepsze co może zrobić państwo to zapewnić warunki dla takiego wzrostu za pomocą strategii politycznych ożywiających innowacyjność (Mazzucato, 2016, s. 68,70$)$.

4. Rosnąca złożoność oraz koszty i ryzyko innowacji będą sprawiać, że coraz bardziej wartościowe będą się stawać powiązania pomiędzy podmiotami, wykraczającymi poza zwykłe relacje rynkowe. Chodzi o związki firm z wyższymi uczelniami, laboratoriami badawczymi, dostawcami usług doradczych i technicznych.

5. Znaczącą metodą wdrażania innowacji, nastawioną na kreowanie nowych pomysłów i rozwiązań, staje się koncepcja popytowego podejścia do innowacji (PARP, 2012). Opiera się ona na lepszym zrozumieniu i poznaniu jawnych oraz ukrytych wymagań - oczekiwań - potrzeb konsumentów. Jej realizacja następuje poprzez tworzenie skutecznych mechanizmów pozyskiwania i wykorzystania informacji płynących od konsumentów, a także bardzo często przez wykorzystywanie ich pomysłów oraz gotowych rozwiązań.

6. Działalność innowacyjna przedsiębiorstw w XXI wieku nie będzie wyłącznie zorientowana na maksymalizację zysku, ale także i to w większym stopniu na określone, zmieniające się w czasie potrzeby człowieka. Te oczekiwania mogą spełniać także małe i średnie przedsiębiorstwa. Zatem należy oczekiwać nowej dynamiki w rozwoju takich dziedzin, w których istotne znaczenie będą odgrywać: 
- tzw. zielone technologie,

- technologie medyczne,

- technologie informatyczne,

- biotechnologie i nanotechnologie,

- sztuczna inteligencja.

7. Na poziom innowacyjności przedsiębiorstw i gospodarek będą wpływać w jeszcze większym wymiarze czynniki kulturowe, tradycje, wysoki poziom kultury organizacyjnej oraz modele rozwoju gospodarczego.

Doświadczenia dwóch różnych krajów: Stanów Zjednoczonych oraz Japonii, dotyczące poziomu i charakteru innowacji pozwalają na stwierdzenie, że nie ma gotowych i tych samych recept na podstawowe sily sprawcze, warunkujące sukces potencjału innowacyjnego. W obu wspomnianych krajach występują nierzadko różne uwarunkowania i mechanizmy tworzenia innowacji jako czynniki rozwoju gospodarczego. Z kolei Chiny z sukcesem przeszły od etapu kopiowania wzorców technologicznych i systemowych do etapu rozwoju wysoko zaawansowanych technologii i ochrony praw intelektualnych. Już pod koniec pierwszej dekady XXI wieku, liczba zgłoszonych w danym roku patentów w Chinach była większa aniżeli w Stanach Zjednoczonych i w Japonii. Zarazem jednak nadal istnieje powszechna opinia, że Chiny same w największym stopniu nie respektują praw własności intelektualnej (Taplin i Nowak, red., 2010, s. 94).

Tworzenie nowej, oryginalnej wiedzy i jej dyfuzja nie są możliwe bez znaczących publicznych i prywatnych wydatków na R\&D jako procent PKB. Obecne doświadczenia pokazują silny związek pomiędzy wynikami na R\&D i liczbą patentów, zgłoszonych w szczególności poza granicami państw, a także udziałem dóbr wysokiej technologii w eksporcie.

Świadomość, że innowacje są siłą napędową współczesnej gospodarki i motorem procesów globalizacji, prowadzi do oczywistej konkluzji, że są one czynnikiem promodernizacyjnym, podnoszącym efektywność, wzmacniają potencjał gospodarczy, a poprzez eksport budują podwaliny pod trwały wzrost ekonomiczny. Tylko częściowo świadomość ta występuje w Europie Centralnej i Wschodniej.

Polska stoi obecnie przed wyzwaniem przejścia od gospodarki ukształtowanej w wyniku transformacji, do grona globalnie konkurencyjnych gospodarek post-przemysłowych.

Jak piszą autorzy Grzegorz Jędrzejczak i Henryk Sterniczuk w publikacjiInnowacyjność - Polski Problem Rozwojowy. Doganianie Zachodu w warunkach nieciagtości istotą wyzwania dla Polski jest wciąż nieadekwatność technicznego, kulturowego i politycznego przygotowania społeczeństwa i gospodarki polskiej do tworzenia produktów i usług globalnie konkurujących nie niską ceną pracy (jak to ma miejsce obecnie) ale jakością i innowacyjnością. Wyzwanie to zde- 
rza się z: (a) niekorzystnymi zmianami demograficznymi redukującymi zasoby pracy, (b) z rozbudzonymi aspiracjami, szczególnie młodego pokolenia, co do osiągnięcia poziomu życia i warunków pracy znanych z krajów Zachodu, oraz (c) last but not least $\mathrm{z}$ gwałtownymi zmianami w gospodarce światowej których jesteśmy świadkami (Jędrzejczak, Sterniczuk, 2020).

\subsection{Podsumowanie}

Postępująca w szybkim tempie globalizacja jest procesem głębokim, wielowymiarowym oraz kompleksowym.

Problemem naukowym jest identyfikacja głównych sił sprawczych, tendencji, mechanizmów i skutków, jakie przynosi. O niektórych tych czynnikach, wydaje się najważniejszych, wspomniano w niniejszym rozdziale pracy. O jednym, szczególnie ważnym fakcie, czyli o oddziaływaniu i wpływie globalizacji na rynki finansowe, wspomniano w różnych aspektach, w kilku miejscach opracowania. Rynki finansowe są, jak podkreślano, jednym z ważnych źródeł nadmiernej finansyzacji gospodarki światowej, niekiedy z ujemnymi dla niej skutkami. Jednak, mimo wszystko, współczesny globalizm, czy kapitalizm to na szczęście nie klasyczne kasyno. Rośnie bowiem płynność globalnych rynków finansowych, co skłania bankowe i pozabankowe instytucje finansowe do szukania nowych form konkurowania, uwzględniających problem ryzyka (Zielińska-Głębocka, 2012).

Choć Adam Smith miał rację stwierdzając, że wolny rynek jest przyszłością gospodarki oraz, że jest jej niezwykle ważnym regulatorem, to zarazem nie wszystkie decyzje podejmowane na globalnym rynku prowadzą do oczekiwanych i pożądanych rezultatów.

Jak wskazuje między innymi Mariana Mazzucato kwestionowanie roli państwa-palący problem od czasów „Badań nad natura i przyczynami bogactwa narodów", Adama Smitha nigdy nie było bardziej aktualne niż dzisiaj. Biznes uznaje się za siłę innowacyjną, podczas gdy państwo zostaje nierzadko obsadzone w roli siły inercji - być może niezbędnej dla „spraw podstawowych”, ale zbyt wielkiej i ciężkiej by stać się siłą napędową (Mazzucato, 2016, s. 5). Jednak światowy kryzys finansowy, a może w jeszcze większym stopniu kryzys globalny spowodowany pandemią nakazuje co najmniej zrewidować ten pogląd.

Muszą się z nim liczyć przede wszystkim przedsiębiorstwa, które nie mogą stawiać na gotowe modele, czy wydawałoby się na sprawdzone instrumenty i sposoby rozwiązywania sytuacji kryzysowych. Tworzenie nowej, oryginalnej wiedzy, jej wykorzystanie i dyfuzja, to dobra droga dla innowacyjnego rozwoju przedsiębiorstw i społeczeństw. Jest to zapewne także dobra droga dla Polski, kraju, który per saldo jest beneficjentem procesów globalizacji. 


\section{Bibliografia}

De Grauwe, P. (2009). Economics of monetary union. Oxford: Oxford University Press.

Dewatripont, M., Rochet, J.-Ch., Tirole, J. i Tribe, K. (2010). Balancing the banks. Global lessons from the financial crises. Princeton: Princeton University Press.

Dornbusch, R. (2000). Keys to Prosperity: Free Markets Sound Money and a Bit of Luck. The MIT Press.

Edvinsson, L. (2012). Universal Networking, Intellectual Capital. W: E. Latoszek, I. Kotowska, A.Z. Nowak, A. Stępniak (red.). European Integration Process in the Regional and Global Settings. Warszawa: Wydawnictwo Naukowe Wydziału Zarządzania Uniwersytetu Warszawskiego.

Ferguson, N. (2010). Czy kres cywilizacji Zachodu? Europa, (12).

Jędrzejczak, G., Sterniczuk, H. (2020). Innowacyjność - Polski Problem Rozwojowy. Doganianie Zachodu $w$ warunkach nieciagtości. Warszawa: Wydawnictwo Naukowe Wydziału Zarządzania UW.

Kaletsky, A. (2010). Capitalism 4.0. The Birth of a New Economy in the Aftermath of Crisis. Public Affairs, June 22.

Kenen, P.B. (1995). Economic and monetary union in Europe: Moving beyond Maastricht. Cambridge: Cambridge University Press.

Kozioł, W. (2004). Wpływ globalizacji rynków finansowych na przebieg kryzysów finansowych. W: I. Koładkiewicz, W. Kozioł (red.). Wyzwania globalizacji. Odpowiedzi przedsiębiorstw. Warszawa: Wydawnictwo Naukowe Wydziału Zarządzania Uniwersytetu Warszawskiego.

Krugman, P. (2008). The Return of Depression Economics and the Crisis of 2008. New York: Norton \& Company Inc.

Krugman, P. (2011). Can Europe Be Saved? New York: Times Magazine, January.

Legrain, Ph. (2010). Aftershock: Reshaping the World Economy after Crisis. London: Little Brown.

Lutkowski, K. (2012). Co się stało w strefie euro. Rzeczpospolita, 15 czerwca.

Mazzucato, M. (2016). Przedsiębiorcze państwo. Obalić mit o relacji sektora publicznego i prywatnego. Poznań: Wydawnictwo Ekonomiczne Heterodoks.

Mazur, G. (2013). Układ Stowarzyszeniowy Unia Europejska-Ameryka Środkowa. Unia Europejska, 222 (5).

Morawski, W. (2004). Mapy drogowe globalizacji: Propozycje analityczno-teoretyczne. W: I. Koładkiewicz, W. Kozioł (red.). Wyzwania globalizacji. Odpowiedzi przedsiębiorstw. Warszawa: Wydawnictwo Naukowe Wydziału Zarządzania Uniwersytetu Warszawskiego.

Noga, M. i Stawicka, M. (2008). Globalizacja a konkurencyjność w gospodarce światowej. Warszawa: CeDeWu Centrum Doradztwa i Wydawnictw.

Nowak, A.Z. (2007). European economic integration: Chances and challenges. Warszawa: Wydawnictwo Naukowe Wydziału Zarządzania Uniwersytetu Warszawskiego.

Nowak, A.Z. i Shachmurove, Y. (2012). End of eurozone?, W: Understanding Global Economy - National and Regional Studies. Warszawa: Wydawnictwo Naukowe Wydziału Zarządzania Uniwersytetu Warszawskiego.

Nowak, A.Z. (2013). Współczesny świat w erze turbulencji. W: J. Bogdanienko. W. Piotrowski (red.). Zarzadzanie: tradycja i nowoczesność. Warszawa: PWE.

Nowak, A.Z., Ryć, K. i Shachmurove, Y. (2014). Real convergence as the way to heal the eurozone?, Przeglad Ustawodawstwa Gospodarczego, (4). 
PARP (2012). Dlaczego warto wykorzystywać popytowe podejście do tworzenia innowacji? Wnioski ze spotkań Klubu Innowacyjnych Przedsiębiorstw. Warszawa.

Prahalad, C.K. i Krishnan, M.S. (2010). Nowa era innowacji (The new age of innovation: Driving Co-Created Value Through Global Networks). Warszawa: Wydawnictwo Naukowe PWN.

Ravenhill, J. (2005). Global Political Economy, Oxford: Oxford University Press.

Soros, G. (2008). Markets: The New Paradigm for Financial The Credit Crisis of 2008 and What It Means. New York: Public Affairs, May.

Stiglitz, J.E. (2009). Capitalistic Fools. Vanity Fair, January.

Stiglitz, J.E. (2010). Can the Euro be Saved? Project Syndicate, http://www.project-syndicate. org/commentary/stiglitz125/English.

Stojano, A. (2009). Research, Quality, Competitiveness. European Union Technology Policy for the Knowledge-based Society. Berlin: Springer Science+Business Media.

Taplin, R. i Nowak, A.Z. (red.) (2010). Intellectual Property, Innovation and Management in Emerging Economies. London: Routledge.

Tidd, J. i Bessant, J. (2011). Zarzadzanie innowacjami (Managing innovation). Warszawa: Oficyna Wolters Kluwer, Polska.

Zielińska-Głębocka, A. (2012). Wspótczesna gospodarka światowa. Przemiany, innowacje, kryzysy, rozwiazania regionalne. Warszawa: Oficyna Wolters Kluwer business. 
Rozdział 2

\title{
Przyczyny ekonomicznej i społecznej kontrrewolucji antyliberalnej*
}

\begin{abstract}
Streszczenie
Artykuł analizuje kwestie związane z obecnym etapem globalizacji. Dostrzega główne przyczyny ekonomicznej i społecznej kontrrewolucji antyliberalnej oraz podkreśla jej wpływ na nowo rodzący się kształt światowego ładu gospodarczego.

Autor podziela punkt widzenia Josepha E. Stiglitza, że Unia Europejska jest taką organizacją, która może i powinna w większym stopniu stanowić punkt odniesienia dla integracji gospodarczej i społecznej, a przez to i dla nowo kształtującego się globalnego ładu ekonomicznego. Zwiększenie integracji politycznej, regulacyjnej i stymulacyjnej roli państwa w gospodarce nie powinno oznaczać zastępowania rynkowej konkurencyjności, poprzez politykę protekcjonizmu i nacjonalizmu ekonomicznego.
\end{abstract}

Słowa kluczowe: globalizacja, kontrrewolucja antyliberalna, paradygmat rozwojowy, Unia Europejska, Nowa Ekonomia Strukturalna.

\section{Reasons for the Economic and Social Anti-liberal Counter-revolution}

\section{Summary}

The article deals with the issues related to the current stage of globalisation. It analyzes the main causes of the economic and social anti-liberal counter-revolution and highlights its influence on the newly emerging shape of the global economic order.

The author shares the point of view of Joseph E Stiglitz that the European Union is an organization that can and even should, to a greater extent, constitute a reference point for economic and social integration in the newly shaping global economic order. The

Tekst ten napisany i zaktualizowany w oparciu o wcześniejszy anglojęzyczny autorski rozdział pt. What is the Future of the Global Economy? W: J.Y. Lin i A.Z. Nowak (red.) (2018). New Structural Policy in an Open Market Economy. Warszawa: Wydawnictwo Naukowe Wydziału Zarządzania UW. 
increase of the political integration, as well as a regulatory and stimulating role of the state in the economy should not mean replacing market competitiveness through a policy of protectionism and economic nationalism.

Keywords: globalization, anti-liberal counter-revolution, development paradigm, European Union, New Structural Economy.

\section{Wprowadzenie}

Jak wspomniano wcześniej w tej publikacji interwencja na szeroką skalę ostatecznych pożyczkodawców (rządów i banków centralnych) zakończyła eskalację utraty płynności finansowej przez zdecydowaną większość podstawowych światowych podmiotów gospodarczych i finansowych (banki komercyjne, fundusze inwestycyjne, fundusze ubezpieczeniowe itp.). Spowodowało to wzrost optymizmu w gospodarce globalnej. Przyspieszenie tempa wzrostu w gospodarce nastąpiło głównie za sprawą ożywienia w handlu i w inwestycjach (https://www. ppr.pl/wiadomosci/oecd-gospodarka-swiatowa-w-2018-i-2019-r).

Istnieje wszakże obawa, że coraz więcej rządów, dostrzegając słabości obecnego etapu globalizacji, może przesadnie chronić własne gospodarki przed zagraniczną konkurencją, w nadziei, że przyniesie to wyłącznie dobre rezultaty ekonomiczne i społeczne. Jednak coraz częściej jest stawiane pytanie o rolę państwa i rynku w procesach gospodarczych. Ma to także związek z epidemią koronawirusa.

Poprzedni światowy kryzys finansowy postawił w centrum uwagi między innymi kwestię kontroli międzynarodowych przepływów kapitału. Obecnie w szczególności w odniesieniu do gospodarek wschodzących pojawia się kwestia zasadności wprowadzenia określonych narzędzi kontroli, na przykład transferu kapitału (Wojtyna, 2017), ale temat ten zasługuje na oddzielne potraktowanie.

\subsection{Przyczyny ekonomiczne i społeczne kontrrewolucji antyliberalnej}

Coraz więcej krajów mówi otwarcie o tym, aby nawet w ograniczonym stopniu zamykać swoje gospodarki przed zagraniczną konkurencją lub przynajmniej bardziej koncentrować się na wykorzystaniu własnych zasobów.

Jednakże problem jest znacznie poważniejszy i głębszy. Grzegorz W. Kołodko w książce pt. Nowy pragmatyzm kontra nowy nacjonalizm trafnie zauważa, że występujące obecnie na świecie zjawiska i procesy społeczno-gospodarcze są coraz bardziej skomplikowane i konfliktogenne (Kołodko i Koźmiński, 2017). Autor ten jest gotów przypisać je w dużej mierze nierównowadze zarówno 
społecznej, jak i gospodarczej, ale również procesom demograficznym oraz zagrożeniom naturalnego środowiska człowieka. Jego zdaniem, zjawiska te nie są jeszcze dostatecznie objaśnione przez nauki ekonomiczne, ponieważ - jak twierdzi - dotychczasowe szkoły ekonomii, a zwłaszcza ekonomii głównego nurtu, okazują się przestarzałe, nieadekwatne dla nowych problemów i w tym zakresie należy poszukać czegoś nowego (Kołodko i Koźmiński, 2017, s. 11).

Andrzej K. Koźmiński uważa z kolei, że „ludzie na całym świecie zaczynają aspirować do coraz wyższego poziomu dobrobytu, i jak dawniej, w minionych wiekach, pokornie godzili się ze swoim losem, tak w chwili obecnej takiej zgody już nie ma i występuje potencjał gwałtownego protestu" (Kołodko i Koźmiński, 2017, s. 11).

Pogląd ten koresponduje z głównymi konkluzjami badań Thomasa Piketty'ego, który w swojej książce pt. Kapitat w XXI wieku stwierdza, iż „dynamika akumulacji kapitału prywatnego prowadzi nieuchronnie do coraz większej koncentracji bogactw i władzy w kilku rękach" (Piketty, 2015, s. 11). Thomas Piketty konkluduje: „Kiedy wskaźnik rentowności kapitału przewyższa w sposób trwały stopę wzrostu produkcji i dochodu, jak działo się to do XIX wieku i może stać się normą w XXI wieku, kapitalizm automatycznie tworzy arbitralne nierówności nie do zniesienia, stawiając pod znakiem zapytania podstawowe wartości, na jakich opierają się nasze demokratyczne społeczeństwa” (Piketty, 2015, s. 11). Wątpi on, iż „równoważące się siły wzrostu, konkurencji i postępu technicznego prowadziły spontanicznie do redukcji nierówności i harmonijnej stabilizacji w zaawansowanych fazach rozwoju, jak myślał [Simon - red.] Kuznets w XX wieku” (Piketty, 2015, s. 11).

W swoich badaniach Thomas Piketty słusznie zagłębia się w historię, chce bowiem wykazać, że amerykańskie marzenie, czyli obietnica egalitarnego kapitalizmu w stylu zachodnim, nie jest w stanie się spełnić i prawdopodobnie w przyszłości nic się tu nie zmieni. W systemie tym bowiem, tempo wzrostu gospodarczego jest zawsze niższe od stopy zysku z zainwestowanego kapitału. Ze wzrostu gospodarczego korzysta całe społeczeństwo, z zysku natomiast tylko najbogatsi (Piketty, 2015, s. 373).

Jan Zielonka profesor Studiów Europejskich na Uniwersytecie w Oksfordzie, w książce pt. Kontrrewolucja. Liberalna Europa w odwrocie, próbuje dostrzec przyczyny, które stały i stoją u podstaw „kontrrewolucji” antyliberalnej i ustanowienia rządów i partii politycznych kwestionujących liberalną odmianę demokracji oraz reformy rynkowe oparte o konsensus waszyngtoński (Zielonka, 2018). „W całej Europie politykę w coraz większym stopniu postrzegano jako sztukę instytucjonalnej inżynierii, nie zaś jako sztukę negocjacji między elitami a elektoratem. Coraz więcej władzy powierzano instytucjom, które nie zostały wyłaniane w wyborach powszechnych - bankom centralnym, sądom konstytucyjnym, agencjom regulacyjnym - by upewnić się, że podejmowaniem decyzji politycznych będzie 
rządzić rozum, nie zaś namiętności. Uleganie naciskom społecznym uważano za nieodpowiedzialne, jeśli nie wręcz niebezpieczne [...] Mówiono, że obywateli należy raczej edukować niż słuchać" (Zielonka, 2018, s. 24).

Choć ta zaskakująca diagnoza Jana Zielonki, ekonomisty o poglądach liberalnych, który, mimo wspominanej wyżej krytyki, wierzy jednak w odrodzenie nowego liberalizmu, zasługuje na przytoczenie. Mamy bowiem do czynienia, przynajmniej na kontynencie europejskim, ale i w Stanach Zjednoczonych, z wyraźnie zauważalnymi tendencjami, które przekładają się jednocześnie na charakter i architekturę nowego ładu ekonomicznego i społecznego.

Dani Rodrick już wcześniej twierdził, że istnieje konflikt między demokracją, nieograniczoną globalizacją gospodarczą i autonomią bądź suwerennością państw. Dowodzit, że niemożliwa jest koegzystencja tych trzech celów polityki na poziomie państwa narodowego.

Brytyjski tygodnik The Economist (2018) w analizie pn. Dlaczego demokracja umiera przypomniał, że w 1941 roku na świecie było tylko kilka demokracji. Za to do 2000 roku tylko w 8 krajach nie przeprowadzono wolnych wyborów. W badaniach dokonanych w 38 krajach, cztery na pięć osób preferowało wtedy system demokratyczny.

Wtedy to właśnie, w 1989 roku, Francis Fukuyama wieszczył „koniec historii” - demokracja zwycięży - system liberalnej demokracji będzie powszechny, a gospodarka rynkowa niezagrożona (Fukuyama, 2009).

Obecnie rzeczywiście mamy do czynienia z kwestionowaniem niektórych podstaw demokracji liberalnej. Proces ten wyraźnie przyspieszył w czasie kryzysu finansowego w latach 2007-2009, a wraz z postępującą destabilizacją spowodowaną migracją i nasileniem konfliktów zbrojnych:

1) narosły odczucia społeczne, że elity demokratyczne nie potrafią sobie poradzić w pełni lub całkowicie z pokonaniem kryzysu oraz napięciami na tle politycznym i społecznym. Największy kryzys finansowy od czasu Wielkiej Depresji lat trzydziestych XX wieku, narastający kryzys zadłużenia w Europie, biliony publicznych pieniędzy przekazane na ratowanie banków, pogłębiające się nierówności majątkowe, to wszystko przeraziło i sfrustrowało miliony osób;

2) nie pojawiło się wielu nowych silnych przywódców o demokratycznych przekonaniach w rodzaju Konrada Adenauera, Margaret Thatcher czy ojców założycieli Unii Europejskiej. Pojawili się za to silni przywódcy (strongmeni), którzy podważyli zaufanie do demokracji liberalnej i dotychczasowych elit. Nowi silni przywódcy (strongmeni) zaproponowali natomiast:

- rozmontowanie lub ograniczenie dotychczasowych instytucji i obyczajów demokratycznych;

- wykreowanie i poszukiwanie wroga (Donald Trump za głównego wroga uznał elity demokratyczne i liberalne). W zamian nastąpiło poszukiwanie nowych, 
lojalnych elit, posiadających kwalifikacje, które nie kwestionują autorytetu przywódcy (także od strony intelektualnej). Elity islamskie z kolei przestraszyły się rosnącej roli nowych elit świeckich - nieudany, co prawda, zamach w Turcji był jednak dla nich sygnałem zagrożenia ich pozycji;

- nową politykę gospodarczą, która odwołuje się do pojęcia suwerenności gospodarczej i inaczej definiowanego interesu narodowego w warunkach procesów globalizacji.

\subsection{Znaki zapytanie w sprawie międzynarodowego ładu}

Powyższe rozważania prowadzą także do postawienia znaków zapytania, związanych z dotychczasowym ładem w skali światowej, w szczególności z ładem gospodarczym. Jak już wcześniej w rozdziale poprzednim podkreślono do niedawna paradygmat rozwojowy był oparty na wspomnianym konsensusie waszyngtońskim. Wyrastał on nie tylko z naukowych badań, ale także z realnych tendencji, występujących w procesie globalizacji.

Polityka gospodarcza, oparta na konsensusie stała się istotnym elementem transformacji systemowej w wielu krajach tzw. gospodarek wschodzących, w tym i Polski.

Jednak bezkrytyczna wiara w samoczynne mechanizmy naprawcze „wolnego rynku" nie sprawdziła się, co - jak wspomniano - ukazał w szczególności światowy kryzys finansowy z lat 2007-2009, którego skutki - jak się wydaje - nie zostały ostatecznie i trwale przezwyciężone. Dochodzą do tego konsekwencje globalnej pandemii koronawirusa.

W konsekwencji rosną szeregi ekonomistów, ale i społeczeństw kwestionujące model rozwojowy oparty głównie na rynkach, bez należytego wsparcia regulacyjnego i kontrolnego ze strony państwa. Do krytyki modelu, którego podstawą są zasady neoliberalne, dołączyć można wszystkie inne ich konsekwencje: frustracje i nierówności społeczne, polityczne i ekologiczne zagrożenia. Obecnie wiemy także na pewno, że pandemia koronawirusa zaburzyła świat, jaki znaliśmy dotychczas. Na miliony ludzi sprowadziła wiele nieszczęść, przyniosła ogrom niepewności i nierzadko zagubienia, ale jednocześnie zmusiła do refleksji i debaty, a nade wszystko działania ze strony rządów, instytucji i organizacji po to, aby przeciwdziałać jej różnorodnym skutkom, występujących w krótkim i długim okresie.

\subsection{Charakterystyka nowych tendencji globalizacyjnych}

Rozważania należy poprzedzić ogólną charakterystyką nowych tendencji w gospodarkach najważniejszych krajów świata oraz konsekwencji nowych zja- 
wisk w procesie globalizacji. Coraz szybciej postępuje rewolucja technologiczna. Zbieranie i przechowywanie ogromnych ilości informacji do celów analitycznych w różnych dziedzinach praktykowane było od dawna. Jednak obecnie gwałtowny wzrost i dostępność danych (big data), a jednocześnie ich zaprogramowana selekcja prowadzą do uzyskania jakościowo nowych możliwości.

Łączenie i zestawianie relacji, hierarchii i różnorodnych powiązań, zbieranie i selekcjonowanie danych z różnych źródeł, w szczególności w sferze gospodarczej, otwiera nowe możliwości podejmowania szybkich i bardziej wiarygodnych decyzji oraz zmian w strategiach biznesowych. $Z$ tej postępującej technologicznej rewolucji korzystają w pierwszej kolejności wielkie korporacje transnarodowe. One bowiem najszybciej dysponują zasobami umożliwiającymi dopasowywanie, oczyszczanie i przekształcanie danych w różnych systemach, również po to, aby uzyskać przewagę konkurencyjną na globalnym rynku.

W wielu krajach (na przykład w Chinach, Indiach, Izraelu) obserwujemy szybkie przechodzenie od rozwoju imitacyjnego do rozwoju opartego na innowacjach. Prowadzi to do coraz większych sporów, a nawet konfliktów, na przykład w kwestii przestrzegania praw autorskich.

Kryzys finansowy lat 2007-2009 zmienił na trwałe dynamikę rozwojową tradycyjnych oraz nowo rodzących się potęg gospodarczych. Kontynent azjatycki staje się jednym z najważniejszych centrów gospodarki światowej. A co także bardzo ważne - pojawianie się nowych potęg gospodarczych wcale nie opiera się wyłącznie na zasadach neoliberalnych. Nawet Międzynarodowy Fundusz Walutowy zakwestionował główne założenia konsensusu waszyngtońskiego.

Coraz bardziej bezwzględna rywalizacja na globalnym rynku odbywa się w sytuacji naturalnych zasobów na ziemi, które wyczerpują się. Ale pojawiają się również opinie, że jeszcze groźniejszy na dłuższy czas jest brak wspólnej troski o ochronę środowiska naturalnego i spory wokół polityki klimatycznej.

Pogłębia się podział na beneficjentów i outsiderów współczesnej globalizacji. Jak wspomniano wcześniej, rosną nierówności, stawiając pod znakiem zapytania podstawowe wartości, na jakich opierają się współczesne społeczeństwa. Wywołuje to bunt i narastanie sprzeciwu wobec praktyk globalizmu i jego bezkrytycznych obrońców.

Wszystkie wymienione wcześniej zjawiska, w różnym stopniu sprzyjają pojawieniu się nacjonalizmów gospodarczych i przekonaniu, iż w obliczu słabości i ułomności dotychczasowych tendencji występujących na globalnych rynkach, należy wprowadzić jakieś formy protekcjonizmu, ograniczeń w wolnym handlu, nawet jeśli potencjalnie będzie to grozić wybuchem konfliktów handlowych. Takie podejście wzmacnia też rolę, wydawało się już nieco mniej eksponowanego znaczenia soft i hard power poszczególnych państw.

Ów „nowy nacjonalizm” - jak nazywają go Grzegorz W. Kołodko i Andrzej K. Koźmiński, autorzy książki pt. Nowy pragmatyzm, kontra nowy nacjonalizm 
(2017, s. 7) - charakteryzuje się w obecnych warunkach również „odrodzeniem agresywnych postaw, poglądów i polityki, która wydawało się wygasła już raz na zawsze po straszliwych doświadczeniach dwóch wojen światowych".

Tak więc w globalnej rywalizacji o charakterze gospodarczym wraca znaczenie polityki zagranicznej, która zakłada połączenie soft i hard power (między innymi czynników politycznych i manipulacyjnych) jako istotnych elementów skutecznie chroniących i wzmacniających interes narodowy.

\subsection{Globalizacja, ale jaka?}

Skoro istnieje coraz powszechniejsze przekonanie, że na obecnym etapie rozwoju gospodarczego globalizacja oparta na neoliberalnych zasadach powinna być gruntowanie przemyślana, to w jakim kierunku powinny nastąpić korekty lub zmiany obecnego stanu?

Czy istnieje realistyczna koncepcja, aby skorzystać z nieodwracalności procesu globalizacji z jego także pozytywnymi rezultatami, ale dla coraz większej liczby państw świata. A jednocześnie, jak trzeba zminimalizować ewidentne słabości i wynaturzenia, skutkujące narastającą groźną degradacją społeczną i buntem wielu społeczeństw?

Ktoś, kto tylko w jednej dziedzinie skutecznie zaprojektuje i zapanuje nad żywiołem oraz siłą współczesnych rynków, w tym przede wszystkim rynków finansowych, a przez to zmieni w istotny sposób procesy i wektory globalizacji, zasłuży na Nagrodę Nobla.

Warto jednak przynajmniej nie popełniać nowych błędów lub nie warto wspierać tych scenariuszy zmian, które mogą potencjalnie tworzyć nowe zagrożenia, a może i nowe, poważne konflikty. Próby rozwiązywania sprzeczności naturalnych interesów koncernów czy państw poprzez formy indywidualnego protekcjonizmu, politykę nakładania ceł, zastępowanie rynkowej konkurencyjności, prowadzenie agresywnych strategii politycznych, zastępujących mechanizmy ponadnarodowych negocjacji i uzgodnień, doprowadzą najpewniej tylko do powrotu egoizmów narodowych.

Tymczasem w globalnej gospodarce, gdzie istnieje również obiektywna rywalizacja i walka o interesy narodowe, państwa narodowe są skazane nierzadko na porażki, ponieważ poprzez realne niebezpieczeństwo izolacjonizmu lub separacji państwa te mają znacznie mniejsze możliwości realizacji swoich interesów. Dotyczy to nawet tak potężnych i wiodących państw, jak Stany Zjednoczone. Choć do niedawna wydawało się to niemożliwe.

Zwiększenie regulacyjnej i stymulacyjnej roli państwa w gospodarce - jako konieczny postulat ograniczenia niekorzystnych procesów zachodzących na globalnym rynku - nie oznacza wyboru na rzecz ograniczania integracji i świa- 
towego handlu czy próby zastępowania rynkowej konkurencyjności poprzez politykę protekcjonizmu i nacjonalizmu ekonomicznego.

Przy wszystkich mankamentach, integracja i swobodny przepływ technologii, kapitału i siły roboczej to jedne $\mathrm{z}$ najsilniejszych impulsów rozwojowych w skali państw, regionów i świata. „Zbiurokratyzowane wszechmogące państwo jest tak samo nie do przyjęcia, jak całkowity wolny rynek" (Nowak i Ryć, 2017, s. 81).

\subsection{Gdzie szukać dodatkowych impulsów rozwojowych?}

Skoro próba zastąpienia dotychczasowego neoliberalnego ładu na drodze różnych form hegemonii jego głównych aktorów, a nie poprzez próby konsensusu, zostałaby zrealizowana, to globalna gospodarka będzie stawała się jeszcze poważniejszym zarzewiem globalnych konfliktów.

Procesy globalizacji należy zatem poddać większej kontroli ze strony organizacji ponadnarodowych lub za pośrednictwem regulacji prawnych i innych, które zostaną uzgodnione poprzez konsensus lub przynajmniej poprzez większość państw. Będzie to wszakże niesłychanie trudne do zrealizowania. Realistycznie oceniając, nadzieja, iż jest możliwy na szczeblu globalnym „,nowy pragmatyzm" ze strony głównych aktorów światowej gospodarki, wydaje się być płonna. Warto więc poszukać rozwiązań sprawdzonych nie tyle w ujęciu globalnym, ile $\mathrm{w}$ regionalnym.

\subsubsection{Spójrzmy na Unię Europejską}

Unia Europejska jest taką organizacją, która może i powinna w większym stopniu stanowić punkt odniesienia dla integracji gospodarczej i społecznej, a przez to szerzej - dla globalnego ładu.

Laureat Nagrody Nobla, Joseph E. Stiglitz, w książce pt. Euro. W jaki sposób wspólna waluta zagraża przyszłości Europy (Stiglitz, 2017), przekonująco ukazuje, jak dotychczasowe rozwiązania, szczególnie w strefie euro, przyczyniają się raczej do tworzenia rozbieżności niż spójności w europejskiej wspólnocie, zadaje pytanie, czy Europa może rozwijać się bez euro?

W odróżnieniu od większości ekonomistów amerykańskich, Joseph E. Stiglitz pozytywnie rozważa, jak stworzyć strefę euro, która będzie działać. Ma on nadzieję, że to co proponuje przyczyni się do wdrożenia rozwiązań, które zapewnią kontynentowi dobrobyt i ,wesprą naszą solidarność”. Jednak zakłada również, że jeśli przeprowadzenie gruntowanych reform, które proponuje, okaże się niemożliwe do wykonania, to wtedy „Europa musi zdecydować się na porzucenie euro, aby ocalić projekt o wiele ważniejszy - projekt politycz- 
nej integracji, istotny nie tylko dla Starego Kontynentu, lecz także dla całego świata" (Stiglitz, 2017, s. 69).

Joseph E. Stiglitz jest przekonany, że jeśli wspólna waluta ma działać, to „potrzeba nam więcej Europy”. Precyzuje przy tym, że nie chodzi mu od razu o federację na kształt Stanów Zjednoczonych Ameryki, gdzie dwie trzecie wszystkich wydatków publicznych ma miejsce na poziomie centralnym, ale o zdecydowane podniesienie obecnego stopnia integracji. Bardziej sprawny Jednolity Rynek i swobodna migracja wymagają ,więcej Europy”. Tym bardziej więc wspólna waluta wymaga „więcej Europy” (Stiglitz, 2017, s. 69).

Zaproponowane przez niego plany reform i gruntownych zmian, które w konsekwencji mają prowadzić do uratowania strefy euro i projektu europejskiego, zasługują na oddzielne potraktowanie, ponieważ kraje strefy euro bez dalszych reform, ale i bez akceptacji dla nich nadal będą narażone na pogłębienie dywergencji i konflikty.

Joseph E. Stiglitz spogląda jednak na Unię Europejską i strefę euro szerzej - w kontekście globalizacji. Pisze on, że „wciąż toczy się debata; jakie są warunki udanej globalizacji. Co robić, jeśli wcale nie przebiega ona tak, jak byśmy sobie tego życzyli? Jakie niesie za sobą koszty i kto na niej zyskuje? Kto przegrywa? W tym sensie sukcesy i porażki Europy są dobrą lekcją na przyszłość - zarówno, jak chodzi o integrację regionalną, jak i o tę naukę na poziomie światowym".

Joseph E. Stiglitz na przykładzie Unii Europejskiej podkreśla, że „integracja gospodarcza (globalizacja) nie powiedzie się, jeśli pozostawi w tyle integrację polityczną. Rośnie więc potrzeba działań kolektywnych - tak by mieć pewność, że wzajemne korzyści będą większe od wyrządzanych sobie nawzajem szkód" (Stiglitz, 2017, s. 69). Przy wszystkich zastrzeżeniach odnośnie do obecnego etapu funkcjonowania Unii Europejskiej i strefy euro, Joseph E. Stiglitz, traktuje Unię Europejską jako istotny projekt, ważny nie tylko dla Starego Kontynentu. Jak podkreśla „powodzenie projektu europejskiego leży nie tylko w interesie Europy".

Europejską regionalizację można postrzegać jako istotny element globalizacji. Jednak wyjście Wielkiej Brytanii z Unii Europejskiej oraz nie do końca przezwyciężone skutki kryzysu finansowego lat 2007-2009 czy mankamenty strefy euro stawiaja jednak pewne znaki zapytania nad europejskim modelem rozwojowym. Tym bardziej, że pojawiły się nowe azjatyckie potęgi gospodarcze, które uczyniły kontynent azjatycki jednym z najważniejszych centrów gospodarki światowej i tym samym zmieniają wektory globalizacji. 


\subsubsection{Globalizacja z polskiej perspektywy}

Korzyści płynące z integracji gospodarki polskiej z gospodarką światową w ramach Światowej Organizacji Handlu (WTO) oraz Unii Europejskiej i uczestnictwo w procesie globalizacji pociągnęly za sobą także pewne zjawiska ujemne, które należy traktować jako koszty. Jednak w ogólnym bilansie korzyści przeważają nad kosztami.

Polska, jako kraj doganiający państwa najbardziej rozwinięte, dokonuje także rewizji powszechnie uznawanych teorii ekonomicznych. W większym stopniu przygląda się i wyciąga praktyczne wnioski z doświadczeń tych krajów, które osiągnęły sukces gospodarczy, nie podążając klasyczną drogą neoliberalizmu. Natomiast zwraca zdecydowanie większą uwagę na rozwój gospodarczy jako proces przemian strukturalnych i politykę przemysłową, która jest ważnym narzędziem, pozwalającym wytyczać priorytety w zakresie wykorzystania ograniczonych zasobów. Stąd też zainteresowanie polskich władz doktryną Nowej Polityki Strukturalnej, której jednym z najważniejszych autorów jest chiński ekonomista Justin Yifu Lin. Istota tej doktryny polega na tym, że czynnikiem o znaczeniu decydującym dla sukcesu rozwojowego jest państwo, które umożliwia ten rozwój, prowadząc odpowiednią politykę przemysłową.

Jak wskazuje Justin Yifu Lin, rozwój gospodarczy jest procesem przemian strukturalnych. Pożądana polityka przemysłowa powinna mieć zatem na celu ułatwianie rozwoju branż posiadających ukryte przewagi konkurencyjne, ale również powinna pomóc firmom w wychodzeniu $\mathrm{z}$ tych branż, w których dany kraj traci przewagi komparatywne.

$\mathrm{Na}$ konkurencyjnym rynku rządy powinny wynagradzać przedsiębiorstwa za wnoszenie wartości dodanych do domeny publicznej, wypracowanych przez pierwszych inicjatorów w nowych branżach - tych, w których kraj posiada ukryte przewagi komparatywne - ale także zapewniać i koordynować wspieranie twardej i miękkiej infrastruktury, aby obniżać koszty transakcyjne (Lin, 2017, s. 199-200).

Polska w pewnych segmentach polityki gospodarczej korzysta obecnie ze wskazań Nowej Ekonomii Strukturalnej, szczególnie poprzez bardziej aktywną rolę państwa, usuwanie barier inwestycyjnych w celu nadrobienia opóźnienia technologicznego w wielu ważnych sektorach gospodarki. Polska w warunkach globalnej gospodarki chce więc uwolnić i uruchomić istniejący potencjał wzrostu, a przez to osiągnąć sukces rozwojowy. Szuka więc w praktyce rozwiązań, które pozwolą jej jak najkorzystniej zaistnieć w zmieniających się realiach gospodarki światowej. 


\section{Bibliografia}

De Grauwe, P. i Lin, J.Y. (2018). Inżynieria finansowa nie ustabilizuje niestabilnej strefy euro. Obserwator Finansowy, 19 kwietnia.

Financial Times (2018). Komentarz redakcyjny, 28 czerwca.

Fukuyama, F. (2009). Koniec historii. Kraków: Wydawnictwo Znak.

http://globaleconomy.pl

https://www.ppr.pl/wiadomosci/oecd-gospodarka-swiatowa-w-2018-i-2019-r

Kołodko, G.W. i Koźmiński, A.K. (2017). Nowy pragmatyzm kontra nowy nacjonalizm. Warszawa: Wydawnictwo Prószyński i S-ka.

Krugman, P. (2008). The Return of Depression Economics and the Crisis of 2008. New York: W.W. Norton \& Company Inc.

Lin, J.Y. (2017). Nowa Ekonomia Strukturalna dla gospodarek doganiających. W: J.Y. Lin, A.Z. Nowak (red.). Nowa Ekonomia Strukturalna wobec krajów mniej zaawansowanych. Warszawa: Wydawnictwo Naukowe Wydziału Zarządzania Uniwersytetu Warszawskiego.

Nowak, A.Z. (2013). Współczesny świat w erze turbulencji. W: J. Bogdanienko, W. Piotrowski (red.). Zarzadzanie: tradycja i nowoczesność. Warszawa: PWE.

Nowak, A.Z., Wojtaszczyk, K.A. i Zamęcki, Ł. (2016). Poland in the European Union. Madrid: Schedas.

Nowak, A.Z. i Ryć, K. (2017). Polityka w regionach $w$ warunkach globalizacji. Warszawa: Wydawnictwo Naukowe Wydziału Zarządzania Uniwersytetu Warszawskiego.

Nowak, A.Z. i Lin, J.Y. (2017). New Structural Economics for Less Advanced Countries. Warszawa: Wydawnictwo Naukowe Wydziału Zarządzania Uniwersytetu Warszawskiego.

Nowak, A.Z. i Taplin, R. (2010). Intellectual Property, Innovation and Management in Emerging Economics. London: Routledge.

Piketty, Th. (2015). Kapitat w XXI wieku. Warszawa: Wydawnictwo Krytyki Politycznej.

Stiglitz, J.E. (2006). Making Globalization Work. New York: W.W. Norton \& Company Inc.

Stiglitz, J.E. (2008). The Triumphant Return of John Maynard Keynes. Guatemala Times, 5 December.

Stiglitz, J.E. (2017). Euro. W jaki sposób wspólna waluta zagraża przyszłości Europy. Warszawa: Wydawnictwo Krytyka Polityczna.

Why the democracy dies (2018). The Economist 16 June, (12).

Wojtyna, A. (2008). Współczesna ekonomia - kontynuacja, czy poszukiwanie paradygmatu. Ekonomista, (1).

Wojtyna, A. (2017). Nowa faza dyskusji o kontroli międzynarodowych przepływów kapitału. Gospodarka Narodowa, listopad - grudzień.

Zielonka, J. (2018). Kontrrewolucja. Liberalna Europa w odwrocie. Warszawa: Wydawnictwo Naukowe PWN. 
Rozdział 3

\title{
Wyzwania w czasie i po pandemii COVID-19. Kapitalizm do naprawy ${ }^{*}$
}

\begin{abstract}
Streszczenie
Nie można zignorować konsekwencji i doświadczeń wynikających z obecnej pandemii. W kwestiach systemowych dominuje coraz częściej przekonanie, że obecny model kapitalizmu jest daleki od ideału, że trzeba go zrewidować i naprawić. „Może być i cudowny, i okropny. Potrzebuje więcej etyki, uczciwych zasad i dobrych praktyk. Jeżeli chcemy go poprawić, to musimy rozwijać firmy oparte na wartościach” (Ohser, 2015). Natomiast w rozwiązaniach systemowych powinniśmy skorzystać w większym stopniu z dorobku zarówno Johna Maynarda Keynesa, jak i Josepha Aloisa Schumpetera.

John Maynard Keynes przekonująco uzasadniał, że państwo powinno stać się inwestorem ostatniej szansy, kiedy sektor prywatny ulegnie osłabieniu lub zamrożeniu (Keynes, 1936). Tak jest też dzisiaj. Joseph Alois Schumpeter twierdził, iż to innowacje zawsze były siła napędową, generującą wzrost w gospodarce rynkowej. Wskazywał na siłę „twórczej destrukcji”, na proces, dzięki któremu innowacja zmienia status quo firm działającym na rynku. Państwa mogą zatem przezwyciężyć recesję, intensyfikując prace nad innowacjami i mądrze je wspierając (Schumpeter, 2009).
\end{abstract}

Słowa kluczowe: pandemia, koronawirus, globalizacja, innowacje, postcovidowy fundament rozwoju.

\section{Challenges During and After the Covid-19. Capitalism to be Corrected?}

\section{Summary}

The consequences and experiences of the current pandemic cannot be ignored. The conviction that the current model of capitalism is far from ideal is more and more dominant, it needs

\footnotetext{
Niektóre stwierdzenia i wątki zawarte w niniejszym opracowaniu Autora pojawiły się także w publikacji Przegladu Ustawodawstwa Gospodarczego (2019, nr 12), pt. Polskie dylematy rozwojowe w świetle Nowej Ekonomii Strukturalnej.
} 
to be revised and corrected. Even before the epidemic, Peter E. Ohser wrote about the present stage of capitalism: "it can be both wonderful and terrible. It needs more ethics, fair rules and good practice. If we want to improve it, we must develop companies based on values. (Ohser, 2015). And he added, in current system we should use to a greater extent the legacy of both: J.M. Keynes and J.A. Schumpeter.

Keynes convincingly argued that the state should become the investor of last resort, when the private sector weakens or freezes (Keynes, 1936). This is the case today. And Schumpeter argued that innovation has always been the driving force of growth in a market economy. He pointed to the power of "creative destruction". The process in which innovation changes the status quo of companies operating on the market. Countries can therefore overcome the recession by intensifying innovation and supporting it wisely (Schumpeter, 2009).

Keywords: pandemic, coronavirus, globalisation, innovations, post-covid foundation of development.

\section{Wprowadzenie}

Dzisiaj nie jesteśmy jeszcze pewni, jaki może być nowy, postcovidowy fundament rozwoju, który mógłby zapewnić bardziej stabilny i zrównoważony wzrost gospodarczy. Wydaje się jednak, że nie uda się też zbudować nowoczesnej, a jednocześnie bardziej stabilnej gospodarki XXI wieku bez próby uwzględnienia zmieniających się warunków i uzasadnionych teraz potrzeb społecznych.

Wzrost społeczno-gospodarczy bardziej inkluzywny i odpowiedzialny społecznie byłby, także dla Polski, dobrym prognostykiem w obliczu wyzwań współczesnej gospodarki globalnej. Jednocześnie bez intensyfikacji prac nad innowacjami oraz nad nową polityką przemysłową trudno będzie przezwyciężyć obecny kryzys o charakterze globalnym.

\subsection{Stary paradygmat rozwojowy do rewizji. Ile państwa, a ile rynku?}

W latach 90. ubiegłego stulecia głównym celem polityki gospodarczej rządów i banków centralnych było osiągnięcie niskiej i stabilnej inflacji - jednak w okresie spadków koniunktury, nawet jeśli inflacja była zbyt wysoka, możliwe było stymulowanie zatrudnienia oraz wzrostu konsumpcji. Polityka fiskalna, jako sposób zarządzania cyklem koniunkturalnym, była jednak traktowana po macoszemu, ponieważ uznano ją za zbyt podlegającą wpływom politycznym.

Zdecydowana większość polityków tolerowała lub reagowała mało skutecznie na strukturalne źródła rosnących nierówności społecznych, które były rezultatem dominujących megatrendów w gospodarce globalnej, w tym szczególnie skut- 
ków finansyzacji rynków, prowadzących do światowych kryzysów finansowych i dysproporcji dochodowych.

Po kryzysie finansowym w latach 2007-2009, kiedy polityczni decydenci stanęli przed wieloma problemami ekonomicznymi i społecznymi, w obliczu rosnącego bezrobocia i spadku popytu, to głównie banki centralne, wspierane przez rządy, podjęły wysiłek walki z kryzysem.

Aby zwalczyć recesję lub spowolnienie gospodarcze, banki centralne obniżyły stopy procentowe i rozpoczęły tak zwane luzowanie ilościowe. W ostatnich latach w wielu krajach następowała powolna poprawa sytuacji gospodarczej, ale pojawienie się pandemii koronawirusa ujawniło $\mathrm{z}$ całą mocą kilka dodatkowych, od dawna nierozwiązanych problemów społecznych.

Charakterystyczne, że pandemia dotknęła stosunkowo najsilniej bogate i dobrze rozwinięte kraje, takie jak: Włochy, Hiszpania, Wielka Brytania czy Stany Zjednoczone Ameryki, w których rola państwa w gospodarce była i jest ograniczona, a instytucje publiczne okazały się słabsze od biznesu prywatnego. Należy jednak pamiętać, iż dzisiejsze wielkie innowacyjne amerykańskie prywatne firmy globalne, choćby takie jak Apple, powstały w dużej mierze - jak podkreśla Mariana Mazzucato, autorka publikacji pt. Przedsiębiorcze państwo. Obalić mit o relacji sektora publicznego i prywatnego - dzięki skutecznemu i bezpośredniemu wsparciu państwa (Mazzucato, 2016).

Ogólnoświatowa pandemia koronawirusa zmusza przede wszystkim do refleksji oraz debaty na temat roli i znaczenia państwa we współcześnie funkcjonujących gospodarkach. Jeszcze do czasu ostatniego kryzysu finansowego (2007-2009) większa rola państwa i jego instytucji była mocno kwestionowana, choć nie wykluczano różnych form interwencjonizmu rządu czy banku centralnego.

Dzisiaj jest chyba najwłaściwszy moment, aby jednostronne i w dużej mierze nieprawdziwe opinie na temat roli państwa w gospodarce i w życiu społecznym podważyć argumentami nie tylko teoretycznymi, lecz także empirycznymi. To również jest właściwy czas, aby obalić mity o roli i znaczeniu sektora publicznego i prywatnego i ich współdziałaniu.

Mariana Mazzucato przekonuje, że właśnie dobrze zorganizowane państwo może dostarczać wizji i „dynamicznego napędu” firmom prywatnym, dzięki którym możliwe staje się to, co w innym przypadku nie miałoby miejsca. Wymaga to traktowania państwa inaczej niż tylko jako „wtrącającego się” czy uławiającego wzrost gospodarczy. Jest ono kluczowym partnerem sektora prywatnego, często partnerem śmielszym, zdolnym podjąć ryzyko, którego prywatny biznes nie podejmie. Dobrze zorganizowane państwo, może być więc państwem przedsiębiorczym, ale też takim, które nie może i nie powinno poddawać się wymaganiom grup interesu, domagających się nierzadko premii, rent i zbędnych przywilejów, takich jak ulgi podatkowe (Mazzucato, 2016). 
Pandemia COVID-19 i jej konsekwencje zmuszą więc nie tylko rządy i decydentów, ale także prywatny biznes do szerokiej refleksji nad naturą, rolą i znaczeniem sektora publicznego. Dotychczasowe wyobrażenie, że sektor publiczny może co najwyżej stwarzać zachęty dla rozwoju innowacji przez sektor prywatny za pomocą różnego rodzaju subsydiów, niskich podatków, sprzedaży uprawnień do emisji, ignoruje fakt, iż w wielu przypadkach przedsiębiorcza inicjatywa pochodzi właśnie od sektora publicznego. W warunkach obecnej pandemii wyraźnie widać, w jakim stopniu od sprawnej i doinwestowanej publicznej służby zdrowia zależy szybszy powrót do normalnego funkcjonowania społeczeństw i ponownego ożywienia wzrostu gospodarczego.

Przedsiębiorstwa państwowe świadczące usługi publiczne z zasady mogą być mniej dochodowe (lub nawet wręcz deficytowe). To właśnie cena, jaką ponosi wspólnota polityczna za to, że chce takie usługi świadczyć. Wspomniana wcześniej Mariana Mazzucato przekonuje, iż państwo przedsiębiorcze to także takie, które inwestuje w obszarach, w których sektor prywatny nigdy by nie zainwestował, nawet gdyby dysponował odpowiednimi zasobami, gdyż nie posiada na przykład dostatecznych możliwości technologicznych.

Ostatnie dekady gospodarki globalnej potwierdzają również, iż hipoteza ekonomiczna (Friedman, 2018) głosząca, że z inwestycjami państwowymi wiąże się niebezpieczeństwo polegające na konsumowaniu w ten sposób oszczędności, które sektor prywatny zawsze mógłby wykorzystać na własne, wysoko efektywne inwestycje, jest nieprawdziwa.

\subsection{Banki centralne wobec stabilności makroekonomicznej}

Pandemia koronawirusa wymusza więc na rządach konieczność ponownego przemyślenia dotychczasowych fundamentów i teorii ekonomicznych. Wielu naukowców, między innymi profesorowie Michael Woodford i Yinxi Xie z Columbia University w Nowym Jorku, twierdzą, że należy pozbyć się złudzeń, iż powrót do „konwencjonalnej mądrości z okresu kryzysu finansowego z lat 2007-2009, zgodnie z którą polityka stóp procentowych banków centralnych sama powinna wystarczyć do utrzymania stabilności makroekonomicznej” jest możliwy.

W ostatnich latach nawet szefowie banków centralnych skłaniali się do przekonywania rządów o korzyściach płynących ze śmielszego wykorzystywania budżetów do pobudzania wzrostu. Christine Lagarde rozpoczęła swoją kadencję jako prezes Europejskiego Banku Centralnego wezwaniem do wprowadzenia w polityce gospodarczej bodźców fiskalnych.

Kryzys koronawirusa najbardziej dotknął tych, którzy mają najmniejsze możliwości aby sobie z nim poradzić - podkreśla Jerome Powell, szef amery- 
kańskiego banku rezerw federalnych (Fed) (Powell, 2020). Parokrotnie ostrzegał on Kongres przed przedwczesnym wycofaniem się z bodźców fiskalnych w zwalczaniu pandemii i próbach ożywienia gospodarczego.

W maju 2020 roku Philip Lowe, prezes Reserve Bank of Australia (RBA), powiedział australijskiemu parlamentowi, że „polityka fiskalna będzie musiała odgrywać większą rolę w zarządzaniu cyklem gospodarczym niż to było w przeszłości”. Brytyjski konserwatywny dziennik Financial Times coraz częściej podkreśla, iż wymyślenie nowych sposobów powrotu do pełnego zatrudnienia staje się ponownie głównym priorytetem wielu ekonomistów.

Atif Mian z Princeton University, Ludwig Straub z Harvard University i Amir Sufi z University of Chicago podtrzymują pogląd, że nierówności osłabiają popyt w gospodarce (Mian, Straub i Sufi, 2020). W swojej ostatniej książce Martin Sandbu, felietonista z Financial Times, sugeruje potrzebę między innymi „wzmocnienia egzekwowania istniejącego prawa pracy w wielu bogatych krajach świata". Jego zdaniem, w zapobieganiu tworzeniu się nowych monopoli pomogłyby również ściślejsze regulacje dotyczące fuzji i przejęć.

\subsection{Tendencje na globalnych rynkach}

Należy zadać bardzo ważne pytanie, związane z procesem globalizacji i licznymi wątpliwościami, czy i w jaki sposób obecna pandemia wpłynie na jej charakter i kierunek? Ograniczona produkcja i przerwane łańcuchy dostaw, głównie w krajach Azji, zakłóciły relacje inwestorskie, co teoretycznie powinno spowodować znaczący wzrost cen, ponieważ trudniej było zdobyć surowce, półprodukty i wyroby gotowe. Jednak obawy o inflacyjny wplyw pandemii na światową gospodarkę nie potwierdziły się.

Ale ważniejsze są tendencje, które pojawiły się, a później utrwaliły się na globalnych rynkach jeszcze w ostatniej dekadzie. Znaczenie własności kapitału w międzynarodowym podziale pracy stało się wartością fundamentalną, trudną do przecenienia. Właśnie własność kapitału, a dzięki temu władza, która należy do akcjonariuszy i podległych im managerów zarządzających korporacją, nawet jeśli ci ostatni rekrutują się spośród miejscowych rezydentów, decydują o charakterze, jakości i perspektywie przedsiębiorstwa. Kapitał jak wiadomo nie ma ojczyzny, natomiast akcjonariusze ją mają.

Wiele krajów, w tym i Polska, zostało włączonych w proces globalizacji gospodarki światowej, osiaggając ewidentne korzyści, ale też, niestety, zostało narażonych na pewne ograniczenia, czy wręcz zagrożenia, które uwidoczniły się obecnie w sposób bardzo wyraźny. Po prostu globalizacja oraz rynki najczęściej utrwalają zarówno producentom krajowym, jak i inwestorom zagranicznym tę samą pozycję, którą miały wcześniej, czyli - podrzędne miejsce w łańcuchu 
tworzenia wartości produktów i usług. Są to bardzo często role: kooperanta, podwykonawcy, czy wykonawcy produktów finalnych, zlecanych przez międzynarodowe korporacje. Nie było to jednak i nie jest zjawisko wyłącznie niekorzystne.

Bezpośrednie inwestycje zagraniczne w wielu krajach przyczyniły się wydatnie do wzrostu zatrudnienia i wydajności pracy, lepszej organizacji procesów produkcji, lepszego wyposażenia czynników wytwórczych w kapitał i wiedzę, czyli w sumie przyczyniły się do unowocześnienia danej gospodarki. Problemem jest jednak to, że nawet w rezultacie znaczących zagranicznych inwestycji bezpośrednich nie dokonał się w tych krajach przełom w zakresie upowszechnienia nowych technologii i innowacji. A stało się tak dlatego, że inwestycje te stanowity najczęściej przeniesienie części procesów produkcyjnych, a znacznie rzadziej ich realne unowocześnienie. Ten charakter inwestycji dobrze ilustruje ich wydajność mierzoną wartością dodaną.

Tymczasem nowoczesność i innowacyjność gospodarki w dalszym ciągu jest charakteryzowana poprzez rozwój innowacyjnych branż przemysłowych: elektroniki, automatyki, robotyki, sztucznej inteligencji, nanotechnologii, biotechnologii itp. A więc byłby pożądany rozwój gospodarczy, dokonujący się poprzez wchodzenie na wyższe poziomy w łańcuchu tworzenia wartości dodanej produktu oraz poprzez szybszej zamianie struktury gospodarki, w której coraz większy udział miałyby sektory o większej produktywności i unikalności.

Nie wydaje się, aby obecny kryzys pandemii koronawirusa zmienił zasadniczo charakter i kierunek procesów globalizacji. Chiny, od jakiegoś czasu wracają na pozycję, którą zajmowały w gospodarce światowej przez setki lat. Są już teraz obok Stanów Zjednoczonych i Unii Europejskiej głównym graczem ekonomicznym, ale także politycznym, czy wojskowym. A do tego wnoszą coraz większy wkład do rozwoju najbardziej zaawansowanych technologii.

Jednak zwiększenie nacisku na bezpieczeństwo dostaw w sektorach strategicznych w polityce handlowej wielu państw może oznaczać spadek dotychczasowego znaczenia Chin w globalnych łańcuchach dostaw. Można także oczekiwać innych tendencji, takich jak: spadek wolumenu handlu międzynarodowego, jego regionalizacja i wzrost protekcjonizmu oraz dywersyfikacja łańcuchów dostaw. Skala kryzysu gospodarczego, związanego z pandemią jest wyjątkowa pod wieloma względami i może dotknąć aż $60 \%$ światowej populacji. Według wyliczeń Światowej Organizacji Handlu (WTO) handel światowy w następstwie pandemii koronawirusa obniży się w 2020 roku o 13-32\% (WTO, 2020).

Dani Rodrik mówi też o tym, że kryzys związany z pandemią wyostrzył dominujące cechy polityki każdego kraju (Rodrik, 2020). Na przykład Chinom udało się szybko ożywić gospodarkę, dzięki popytowi ich towarów ze strony Zachodu. Udział Chin w globalnym handlu zwiększa się. Władze Chin odpowiedziały na pandemię cenzurą informacji o rozpowszechnianiu wirusa, podwyższeniem 
poziomu kontroli społecznej, a następnie masową mobilizacją (szerzej o tych kwestiach w raporcie Polskiego Instytutu Ekonomicznego z 2020 roku).

Matthew Karnitschnig w ogólnoświatowym dzienniku Politico napisał, że pandemia koronawirusa sprawiła, iż potęga Niemiec i Angeli Merkel ujawniły się silniej niż sami by tego chcieli. „Niemcy, niechętny jak dotąd hegemon Europy, przestają już być tacy niechętni. Choć przez kilkadziesiąt lat siła gospodarcza i wpływy polityczne kraju wciąż rosły, niemieccy politycy lękali się urazić wrażliwość sąsiadów, wyczulonych na ich potęgę - przynajmniej w sposób otwarty. Jednak pandemia koronawirusa, a zwłaszcza jej gospodarcze konsekwencje, zmuszają Berlin do przyznania tego, co wielu mówiło już od dawna: Unia Europejska nie przetrwa bez silniejszego przywództwa Niemiec" (Karnitschnig, 2020).

Eksperci z Polskiego Instytutu Ekonomicznego oceniają, że Polska może skorzystać na zmianie szlaków handlowych po pandemii koronawirusa i zyskać nawet ponad 8 mld dolarów rocznie, dzięki przeniesieniu części produkcji z Chin (Raport Polskiego Instytutu Ekonomicznego, 2020). Jest prawdopodobne, że Unia Europejska więcej produkcji półfabrykatów przeniesie teraz do krajów europejskich, zrobi to przede wszystkim kosztem takich krajów, jak Chiny, czy Meksyk. Według obliczeń specjalistów Polskiego Instytutu Ekonomicznego w najbardziej sprzyjających warunkach może dojść do zastąpienia w krajach unijnych $10 \%$ dostaw pólproduktów oraz wyrobów finalnych z Chin produkcją krajową, a kolejnych $10 \%$ dostawami z sześciu nowych państw członkowskich Unii Europejskiej (Czech, Polski, Słowacji, Węgier, Rumunii i Bułgarii).

\subsection{Polityka przemysłowa (strukturalna) szansą na czas pandemii koronawirusa}

Odpowiedzią na te obecne pandemiczne, globalne wyzwania społeczne i gospodarcze jest - jak się wydaje - między innymi realizacja Planu Odpowiedzialnego Rozwoju premiera Mateusza Morawieckiego, w którym podkreśla się istotność połączenia wydajnego i konkurencyjnego systemu rynkowego z państwem umożliwiającym ułatwianie i wspieranie strukturalnych zmian gospodarczych.

Jak stwierdzono w publikacji autorstwa J.Y. Lina i Alojzego Z. Nowaka pt. Polskie dylematy rozwojowe w świetle Nowej Ekonomii Strukturalnej (Lin i Nowak, 2018), na obecnym etapie rozwoju naszej gospodarki jak najbardziej uzasadnione wydaje się szukanie takich działań i podejmowanie takich decyzji, które połączą wydajny i konkurencyjny system rynkowy z przedsiębiorczym państwem, umożliwiającym dokonywanie strukturalnych zmian gospodarczych. 
Dotychczasowa modernizacja w przemyśle oparta w dużej mierze na kopiowaniu importowanych rozwiązań i technologii, daje pośrednie wzmocnienie konkurencyjności polskiej gospodarki. Rozwój gospodarczy - jak wspomniano wcześniej - powinien dokonywać się przez wchodzenie na wyższe poziomy przy tworzeniu wartości dodanej produktu oraz przy zmianie struktury gospodarki, w której coraz znaczniejszy udział miałyby sektory o większej produktywności i unikalności.

$\mathrm{Z}$ tego punktu widzenia pożądana nowa polityka strukturalna staje się realną szansą na zwiększenie innowacyjności polskiej gospodarki. Polska musi rzeczywiście uporać się z fazą rozwojową okresu transformacyjnego i uzyskaniem zdolności rozwojowych gospodarki, niezbędnych do pokonania historycznie ukształtowanej relacji PKB na mieszkańca Polski, stanowiącego około 70\% poziomu PKB państw Europy Zachodniej.

Ta nowa polityka strukturalna wymaga aktywnej roli rządu i instytucji państwa. Premier Mateusz Morawiecki w przedmowie do polskiego wydania wspomnianej wcześniej książki Mariany Mazzucato, mówiąc o roli „przedsiębiorczego państwa” stwierdza: „Jeśli spojrzymy na narzędzia stosowane przez państwa, które osiągają największy sukces we wspieraniu swoich firm, to zauważmy, że korzystają one przede wszystkim z tradycyjnych prerogatyw państwa w zakresie polityki gospodarczej. Wśród narzędzi rozpoznamy bowiem dobrze pomyślaną politykę zamówień publicznych, sprawną politykę finansowania grantów na badania i rozwój, efektywny system podatkowy, odpowiedzialną działalność organów regulacyjnych, czy też łatwe w dostępie finansowanie projektów strategicznych przez państwowe instytucje rozwoju" (Morawiecki, 2016).

Chodzi więc nie o państwo omnipotentne, ale o państwo, w którym sztuką współczesnej polityki przemysłowej czy strukturalnej jest optymalne współdziałanie sektorów publicznego i prywatnego. Mariana Mazzucato, której poglądy gospodarcze cieszą się coraz większą popularnością w środowiskach naukowych, uważa słusznie, że „głównym powodem, dla którego pojęcie błędów rynku jest problematyczne, to rozumienie roli państwa w procesie tworzenia innowacji. Ignoruje ono podstawową kwestię dotyczącą historii innowacji. Państwo nie tylko finansuje najbardziej ryzykowne badania, stosowane bądź podstawowe, ale i często jest źródłem najbardziej radykalnych, przełomowych innowacji. W tym sensie aktywnie tworzy ono rynki, a nie tylko je koryguje" (Mazzucato, 2016).

\section{Podsumowanie}

Pandemia COVID-19, sprowadziła na świat wiele problemów i przyniosła wiele niepewności. Jedną z nich można sprowadzić do pytania, czy czeka nas teraz zbudowanie nowych fundamentów, na których będą oparte systemy spo- 
łeczno-gospodarcze. Czy możemy już mówić o pojawianiu się zalążków nowych paradygmatów, czy podstaw rozwojowych, a może mamy tylko do czynienia z przewartościowaniem dotychczasowych teorii ekonomicznych?

Wydaje się, że te pytanie pozostają na razie jeszcze bez jednoznacznej odpowiedzi. Niniejsza analiza jest refleksją raczej o potrzebie zmian czy korekt, w szczególności w myśleniu i postrzeganiu roli państwa, jego instytucji, a jednocześnie polityki, która realizuje aspiracje i potrzeby społeczne większości obywateli i jest przez nich akceptowana.

Patrząc z perspektywy doświadczeń krajów, które wyszły z grupy państw średniego rozwoju i uzyskały trwałą obecność w grupie liderów innowacyjnej gospodarki, wydaje się, że w przypadku Polski przejście od gospodarki średniego potencjału do gospodarki wysokiego potencjału innowacyjnego wymaga jeszcze uporządkowania kilku innych ważnych spraw.

Z badań przeprowadzonych na Wydziale Zarządzania Uniwersytetu Warszawskiego wynika, że chodzi o:

- minimalizację napięć pomiędzy cyklem politycznym a czasem koniecznym na uzyskanie efektów rozwojowych poprzez porozumienie elit politycznych i gospodarczych oraz uzgadnianie długookresowej strategii gospodarczej i społecznej;

- poważne inwestycje w Badania i Rozwój, na poziomie 2,5\% PKB i wspomaganie przez państwo rozwoju potencjału badawczego w firmach i korporacjach;

- rozwój systemu edukacyjnego, ukierunkowanego na twórczość, nauki ścisłe, technologię i współpracę między ludźmi;

- mobilizację społeczeństwa, opinii publicznej w kierunku rozwoju innowacyjności w życiu publicznym i gospodarce.

\section{Bibliografia}

Friedman, M. (2018). Kapitalizm i wolność. Klasyka wolnorynkowej myśli gospodarczej. Gliwice: Wydawnictwo Helion.

Karnitschnig, M. (2020). Polictico, 25 czerwca.

Keynes, J.M. (1936). The General Theory of Employment, Interest and Money. London: Macmillan.

Lin, J.Y. i Nowak, A.Z. (2018). Nowa Polityka Strukturalna $w$ warunkach otwartej gospodarki rynkowej. Warszawa: Wydawnictwo Naukowe Wydziału Zarządzania Uniwersytetu Warszawskiego, s. 137-138.

Mazzucato, M. (2016). Przedsiębiorcze państwo. Obalić mit o relacji sektora publicznego i prywatnego. Poznań: Wydawnictwo Ekonomiczne Heterodox, s. 70-93.

Mian, A., Straub, M. i Sufi, A. (2020). Indebted Demand. NBER Working Paper, (26940). Morawiecki, M. (2016). Przedmowa. W: M. Mazzucato. Przedsiębiorcze Państwo. Obalić mit o relacji sektora publicznego i prywatnego. Poznań: Wydawnictwo Ekonomiczne Heterodox, s. XXVII, XXXI. 
Osher, P. (2015). Jak naprawić kapitalizm? Sopot: Europejskie Forum Nowych Idei.

Powell, J. (2020). Navigating the Decade Ahead: Implications for Monetary Policy. An economic policy symposium sponsored by the Federal Reserve Bank of Kansas City. Jackson Hole, Wyomin.

Przeglą Ustawodawstwa Gospodarczego (2019, nr 12). Polskie dylematy rozwojowe w świetle Nowej Ekonomii Strukturalnej. Warszawa: PWE.

Raport Polskiego Instytutu Ekonomicznego (2020). Szlaki handlowe po pandemii COVID-19, Wideokonferencja: pie.net.pl/wp-content/upl (dostęp: 28.05.2020).

Rodrik, D. (2020). Will Covid-19 Remake the World?, www.project-syndicate.org./commentary/ will-covid19-remake-the-world-by-dani rodrik-2020-04 (dostęp: 25.04.2020).

Schumpeter, J.A. (2009). Kapitalizm, socjalizm, demokracja. Warszawa: Wydawnictwo Naukowe PWN.

WTO (2020). Trade set to plunge as COVID-19 pandemic upends global economy, https:// www.wto.org/english/news_e/pres20_e/pr855_e.pdf (dostęp 28.05.2020). 


\section{Rozdział 4 \\ Co dla polityki przemysłowej wynika z trylematu Rodrika*}

\section{Streszczenie}

Artykuł analizuje źródła kryzysu światowego w pierwszej dekadzie XXI wieku oraz jego konsekwencje. W literaturze ekonomicznej i społeczno-politycznej toczą się wciąż spory, co do istoty tamtego kryzysu, sposobów jego przezwyciężania i ich długofalowych skutków dla globalizacji. Do pewnego stopnia, podobnie jak w latach trzydziestych ubiegłego stulecia wychodzenie $\mathrm{z}$ recesji wiele krajów zawdzięcza aktywnej polityce rządów i banków centralnych.

W rezultacie oceny i analizy zasadniczych także historycznych przyczyn kryzysu światowego z pierwszej dekady XXI wieku, autorzy zwracają uwagę na zasadniczą rolę polityki przemysłowej, czy strukturalnej rządów i instytucji publicznych. Co najmniej powściągliwie, jeśli nie krytycznie odnoszą się do poglądów do niedawna jeszcze dominujących, iżby ożywić gospodarkę trzeba przede wszystkim zmniejszyć podatki i uelastycznić zatrudnienie. Proces wycofywania się państwa i rosnącej dominacji rynku należy zrewidować, ale też powrót państwa jako aktywnego podmiotu na rynku uważnie kontrolować.

Artykuł podaje liczne i ważne argumenty na rzecz polityki uwzględniającej rozwój sektora usług publicznych. Na podstawie interpretacji trylematu Rodrika zdaniem autorów wyroki międzynarodowych rynków nie będą przyjmowane przez rządzące elity tylko z pokorą i bezkrytycznie. Autorzy tego artykułu mają natomiast nadzieję, iż ich poglądy dotyczące polityki przemysłowej, czy sektorowej mają charakter ponadczasowy.

Slowa kluczowe: światowy kryzys gospodarczy, rola finansów publicznych, państwo, rynek, trylemat Rodrika, polityka przemysłowa, polityka sektorowa.

\footnotetext{
Współautor tego rozdziału - profesor dr hab. Kazimierz Ryć. Tekst ten uzupełniony, wcześniej pt. Polityka gospodarcza i spoteczna po kryzysie. W: A.Z. Nowak, K. Ryć (red.) (2017). Polityka $w$ regionach $w$ warunkach globalizacji. Warszawa: Wydawnictwo Naukowe Wydziału Zarządzania UW.
} 


\section{What Results for Industrial Policy from Rodrik's Trilemma}

\section{Summary}

The article analyzes the sources of the world crisis in the first decade of the 21st century and its consequences. There are still disputes in economic and socio-political literature as to the essence of that crisis, the ways of overcoming it and its long-term consequences for globalisation. To some extent, as in the 1930s, many countries owed their recovery to the active policies of governments and central banks.

As a result of the assessment and analysis of the fundamental and historical causes of the world crisis of the first decade of the 21st century, the authors point out to the fundamental role of industrial and structural policy of governments and public institutions. At least cautiously, but they are rather critical to the views that in order to revive the economy, first of all, goverment needs to reduce taxes and make employment sector more flexible. Meanwhile, a process of the state's withdrawal and the growing dominance of the market should be reviewed, but also the return of the state as an active market player should be carefully monitored.

The article provides numerous and important arguments for a policy that takes into account the development of the public service sector. Based on the interpretation of Rodrik's trilemma, the authors believe that the judgments of international markets will not be accepted by the ruling elite with humility and uncritical attitude. The authors of this article hope that their views on industrial or sectoral policy are still valid.

Keywords: global economic crisis, role of public finance, state, market, Rodik's trilemma, industrial policy, sectoral policy.

\section{Wprowadzenie}

Po latach wielkiego kryzysu 1929-1933, trzydziestu pięciu latach napięć i konfliktów okresu międzywojennego, i po tragicznej II wojnie światowej system kapitalistyczny przechodził dwie fazy w miarę spokojnego rozwoju. Bezpośrednio po II wojnie światowej, w latach 1945-1975, kraje wysoko rozwinięte z kręgu OECD Europy Zachodniej i Ameryki Północnej, przeżyły okres dynamicznego wszechstronnego rozwoju.

Gospodarkę w tej fazie charakteryzowało wysokie tempo rozwoju PKB, praktycznie pełne zatrudnienie, czyli brak wymuszonego bezrobocia, niska, sprowadzona do poziomu pełzającej, inflacja i praktyczne ustąpienie cyklicznego charakteru wzrostu.

Wzrastał dobrobyt społeczeństw Zachodu, a co za tym idzie realne wynagrodzenia pracowników również rosły. Rozpiętości wynagrodzeń pracowników szeregowych i kadr kierowniczych pozostawały umiarkowanie niskie. Utrwalało 
się bezpieczeństwo socjalne pracowników, zarówno w zakresie trwałości stosunku pracy, jak i świadczeń socjalnych. Kooperacja świata pracy i kapitału znajdowała wyraz w różnych formach partycypacji pracowniczej w zarządzaniu czy też udziału pracowników we własności przedsiębiorstwa, czy krajowego kapitału akcyjnego. Kapitalizm tej fazy rozwoju nazywano różnie, stosując różne przymiotniki, jak: państwo opiekuńcze, społeczna gospodarka rynkowa, państwo dobrobytu lub też nadreński model kapitalizmu itp.

\subsection{Dwie fazy przedkryzysowego rozwoju}

Ten typ rozwoju systemu kapitalistycznego załamał się w połowie lat 70 . ubiegłego wieku. Przyczynami tego załamania były zarówno czynniki zewnętrzne, jak i kłopoty gospodarki amerykańskiej, próbującej łączyć budowę wielkiego społeczeństwa z kosztowną wojną i wyścigiem zbrojeń. Doprowadziło to do uchylenia wymienialności dolara amerykańskiego na złoto, a w konsekwencji - rozpadu systemu Bretton Woods, co z kolei zrodziło napięcia, perturbacje i niepewność na rynkach pieniężnych.

Wojny i napięcia na Bliskim Wschodzie oraz słabość dolara wyzwoliły aktywność międzynarodowego kartelu naftowego OPEC, który zdecydował się na zwielokrotnienie ceny ropy naftowej. Wzrost tych cen, perturbacje na rynkach pieniężnych i wyścig płacowo-cenowy wywołały silną inflację, głównie o charakterze kosztowym, tym razem jednak towarzyszyło jej duże bezrobocie. Inflacja plus bezrobocie nie mieściły się w doktrynie keynesowskiej, która dominowała w tej fazie rozwoju kapitalizmu. Nastąpiła rewizja doktryny polityki gospodarczej, opartej na teorii Johna Maynarda Keynesa. Istotne znaczenie miały też liczne wypaczenia praktyki państwa opiekuńczego, jak nadmierna biurokratyzacja, zbytnia rozrzutność wydatków publicznych, mała skuteczność tej polityki w warunkach wysokiego długu publicznego czy osłabiona motywacja do pracy.

W miejsce keynesizmu nastała doktryna neoliberalna, której wzorcem stała się polityka w Wielkiej Brytanii nazywana thatcheryzmem, a w Stanach Zjednoczonych reaganomiką. W polityce tej stawiano na swobodne działanie mechanizmu rynkowego, deregulacje, małe państwo i oszczędny budżet, niskie podatki i liberalizację rynku pracy. Doktryna z czasem przybrała kształt nazywany konsensusem waszyngtońskim, zalecanym wszystkim krajom, zwłaszcza tym, które zabiegały o pomoc Międzynarodowego Funduszu Walutowego i Banku Światowego.

Nowa polityka dała impuls rozwojowi. Udało się pokonać inflację, podtrzymać tempo wzrostu gospodarczego, choć niższe od tempa w poprzedniej fazie, które jest zrozumiałe w przypadku krajów OECD ze względu na wysoki stopień osiagnniętego wcześniej zaawansowania w rozwoju. Z kolei silnym impul- 
sem rozwojowym, zwłaszcza na początku tej drugiej fazy, stała się liberalizacja przepływów kapitałowych i globalizacja, która zapoczątkowała szybki rozwój krajów nazywanych niegdyś trzecim światem.

Krajom OECD dało to rynki zbytu i pole ekspansji kapitałowej, ale zarazem doprowadziło z biegiem czasu do napięć i nierównowagi, będących zarzewiem obecnego kryzysu. Wiązało się to przede wszystkim ze skutkami przenoszenia produkcji korporacji przemysłowych z krajów wysoko rozwiniętych do państw o niskich kosztach pracy. Działanie to przyniosło wzrost łącznej efektywności produkcji zarówno tych korporacji, jak i gospodarki światowej jako całości, lecz jednocześnie zmieniło światowy podział pracy. Spowodowało deindustrializację na Zachodzie i wzrost gospodarczy krajów Wschodu. Stało się też źródłem nierównowagi finansowej, która przyczyniła się do kryzysu.

\subsection{Okoliczności wybuchu kryzysu}

Obecnie powstała już obszerna literatura na temat źródeł kryzysu. Wielu autorów szczyci się tym, że widzieli wcześniej jak kryzys narasta, zapowiadali jego nadejście i ostrzegali przed nim. Ktoś słusznie napisał, iż byli i tacy, którzy przewidzieli aż siedem z ostatnich trzech kryzysów.

Ostatni światowy kryzys finansowy zaskoczył zarówno przedstawicieli głównego nurtu ekonomii, jak i polityków. W świetle dzisiejszych dyskusji można wymienić wiele przyczyn narastających napięć, które prowadziły do niego.

1. Narastanie rozpiętości dochodowych między szeregowymi pracownikami a kadrą kierowniczą korporacji. Rozpiętości te w poprzedniej fazie były dużo mniejsze. Szef firmy zarabiał 20 razy więcej niż zwykły pracownik, teraz w stu wielkich przedsiębiorstwach w Stanach Zjednoczonych szef zarabia 320 razy więcej (Buras, 2012). Pogłębiły się różnice pomiędzy dobrobytem klasy średniej, którego wzrost w czołowych krajach kapitalistycznych zatrzymał się na poziomie sprzed trzydziestu kilku lat, a dochodami elit finansowych, które w istocie zawłaszczyły rezultaty wzrostu produktu krajowego.

2. Silny proces finansyzacji gospodarki. Postępuje proces odrywania się sektora finansów od sektorów realnej gospodarki: przemysłu, rolnictwa, handlu i innych. Samoistny byt procesów finansowych, a więc operacji finansowych bez udziału realnej gospodarki umożliwiały rosnące zasoby płynnych środków pieniężnych zasilanych wysokimi dochodami elit gospodarczych i finansowych. Gra finansowa nazywana casino kapitalizmem rozwija się ze szkodą dla inwestycji w sferze realnej.

3. Przenoszenie miejsc pracy z krajów zaawansowanych w rozwoju do krajów zaliczanych do kategorii wyłaniających się rynków, co osłabiało pozycję negocjacyjną pracowników w krajach zamożnych i hamowało wzrost płac 
realnych. Stagnację dochodów realnych łagodził tani kredyt, który do czasu umożliwiał wzrost konsumpcji finansowanej długiem.

W Stanach Zjednoczonych dług hipoteczny stał się dla wielu rodzin sposobem na finansowanie dodatkowych wydatków. Domy kupione na kredyt i zastawione hipotecznie mogły stanowić zabezpieczenie dalszego kredytu, jeżeli ich ceny, a zatem i wartość rynkowa, wzrastały. Dom nawet kupiony na kredyt stawał się swoistym bankomatem, na przykład przy zakupie samochodu i innych. Tak między innymi rodzily się toksyczne aktywa banków ${ }^{1}$.

4. Niskie stopy procentowe. Nadmiar wolnego kapitału w wyniku wysokich oszczędności mieszkańców Chin, które tylko w latach 2000-2006 wzrosły 38\% do 54\% PKB i mogły być transferowane na zakup obligacji amerykańskich, podnosząc ich ceny i obniżając rentowność. Do tego doszły wysokie oszczędności innych, szybko rozwijających się krajów Azji Południowo-Wschodniej, ciężko doświadczonych kryzysem finansowym 1997 roku, którego przyczyną była zbyt mała płynność zasobu aktywów, obnażona przez ucieczkę kapitałów. Wolne kapitały państw naftowych, mieszczące się w suwerennych funduszach inwestycyjnych zostały więc powiększone o oszczędności Azjatów.

Obfitość kapitału przyniosła w efekcie niskie stopy procentowe i łatwą dostępność kredytu. Stworzone zostały więc warunki do powstania nadmiernego zadłużenia gospodarstw domowych i przedsiębiorstw w wielu krajach, najbardziej widoczne w sektorze budownictwa mieszkaniowego i pozostałych nieruchomości oraz na rynku dóbr trwałego użytku. Zachęcały też do finansowania kredytem wydatków sektora publicznego w wielu państwach. Koszty obsługi długu były bardzo niskie.

5. Ustąpienie niebezpieczeństwa inflacji. Przesuwanie produkcji przemysłowej z krajów zamożnych do krajów taniej siły roboczej powodowało spadek kosztów i cen towarów będących przedmiotem wymiany międzynarodowej, towarów globalnych. Odnosi się to także do części usług, które mogą być świadczone drogą elektroniczną. Spadek wskaźnika cen towarów globalnych i usług hamował wzrost ogólnego wskaźnika inflacji w krajach wysoko rozwiniętych. Sytuacja ta sprzyjała prowadzeniu łagodnej polityki pieniężnej i ekspansywnej polityki budżetowej w wielu krajach. W dyskusji o bezpośrednich przyczynach kryzysu wymienia się je zresztą na samym początku.

6. Brak regulacji i kontroli ze strony rządów i banków centralnych nad tworzeniem i wykorzystywaniem nowych instrumentów finansowych. Chodzi o instrumenty finansowe, pozwalające rozwodnić ryzyko i utrudnić jego

1 Prezes FED B. Bernanke podobno podziwiał: „Głębię i wyrafinowanie amerykańskich rynków finansowych, które umożliwiły gospodarstwom domowym dostęp do kapitału w postaci własnego domu”, za: Mess (2012). 
ocenę. Brak regulacji i kontroli pozwalał też na wysokie lewarowanie aktywów banków i instytucji finansowych.

Powstałe w wyniku tego tak zwane toksyczne aktywa podważyły wiarygodność i instytucji finansowych, doprowadzily do bankructwa lub na próg bankructwa wiele renomowanych banków i ubezpieczycieli, zatrzymały przepływy pieniężne i kredyt. Państwa krajów OECD przeznaczyły setki miliardów dolarów na ratowanie banków przed upadłością. Rządy krajów Europy Zachodniej na ratowanie banków, które nabyły toksyczne aktywa amerykańskie, wydały sumy powiększające dług publiczny. Według szacunków dla tych krajów, działania ratunkowe spowodowały powiększenie długu publicznego ze średnio od 60 do 80\% PKB (Rzeczpospolita, 2012).

\subsection{Kryzys finansów publicznych}

Nie jest wielką przesadą stwierdzenie, że w wyniku kryzysu zadłużenie prywatne zamieniło się w zadłużenie publiczne. Ponadto spadek produkcji spowodowany przemieszczeniem kryzysu bankowego na sferę realną gospodarki spowodował zmniejszenie wpływów podatkowych do budżetów państw przy zwiększonych wydatkach. Wzrost deficytów budżetowych i długu publicznego wywołał niepokój rynków finansowych.

Nastąpiło zmniejszenie zaufania rynków do zadłużonych krajów i spadek popytu na ich obligacje rządowe, obniżenie ceny obligacji i wzrost kosztów obsługi długu. Przyniosło to w rezultacie kryzys lub zagrożenie kryzysem finansów publicznych w wielu krajach. Powstała więc sytuacja mało komfortowa dla ekonomistów neoliberalnych i, przywiązanych do ich idei, polityków. Mechanizmy rynkowe zawiodły, rynek zawinit, pod pręgież postawiono państwo. Czarny PR roztaczany przez publicystów i ekonomistów z kręgu bankowego trafił więc w państwo opiekuńcze, które winne jest nadmiernemu zadłużeniu.

Tak się jednak składa, że państwa typowo opiekuńcze, jak na przykład kraje skandynawskie, nie przeżywają kryzysu finansów publicznych. Dotyczy to państw nie tyle opiekuńczych, co nadmiernie „przyjaznych” dla współobywateli, które gotowe są ponosić duże wydatki publiczne i jednocześnie utrzymywać niskie ciężary podatkowe. Takim państwem przyjaznym była Grecja, w której trudno znaleźć nadmierną opiekuńczość i rozbudowane przywileje socjalne, a jednak zgromadziła wielki dług publiczny.

Niskie stopy procentowe zachęcają do pożyczania i finansowania świadczeń społecznych, a także rozbudowy struktur administracyjnych dających atrakcyjne miejsca pracy, a jednocześnie laskawego traktowania podatników. Obligacje rządowe natomiast finansujące te wydatki, mogą trafiać do rąk zamożnej części 
społeczeństwa. Obligacje są dobrą inwestycją ważoną niskim ryzykiem. Zyskują więc jednocześnie zarówno ubodzy, jak i bogaci.

Pomińmy więc kwestię źródła długu publicznego. Stał się on nadmierny w wielu krajach nie tyle ze względu na rozmiary długu, co z powodu niechęci rynków do jego finansowania. Powstają trudności ze sprzedażą kolejnych transz emisji rządowych papierów. Fakt, że jest to sprawa oceny rynków, a nie rozmiarów długu publicznego, wskazuje przykład Japonii, która mimo iż posiada rekordowy dług publiczny, przewyższający ponad dwukrotność poziom japońskiego PKB, jednak nie ma problemów z jego tanim finansowaniem i obsługą. Jest to bowiem dług zaciągnięty głównie wewnątrz kraju, a więc mniej podatny na działanie kapitału spekulacyjnego. Nadmierne zadłużenie państw wymusza oszczędności tym większe i bardziej dla społeczeństw bolesne, im zadłużenie to jest w ocenie rynków gorsze, to znaczy obciążone większym ryzykiem dla inwestorów.

Oszczędności redukujące popyt wewnętrzny zarówno konsumpcyjny, jak i inwestycyjny, gdy jednocześnie oszczędności podejmuje wiele krajów, będących partnerami handlowymi, osłabiają również eksport. Spadek tempa wzrostu PKB w wyniku malejącego popytu wewnętrznego i zewnętrznego, a tym bardziej spadek rozmiarów PKB, zmniejsza wpływy podatkowe, co niweczy wysiłki bądź zmniejsza skutki wysiłków na rzecz osiągania równowagi finansów państwa. Ta przyczynowość okrężna sprawia, że długi nie maleją, lecz często nadal rosną.

W rezultacie może tylko powstawać opinia, że robi się wiele, aby opanować narastanie długu. Opinia ta ma przekonać rynki o pomyślnych perspektywach uzdrowienia finansów i zachęcić międzynarodowe fundusze inwestycyjne do nabywania papierów dłużnych po cenie w miarę korzystnej dla emitenta. Opinia rynków, mówiąc oględnie, a w istocie opinia międzynarodowych spekulantów finansowych, staje się ważniejsza od celów rozwojowych państw i aspiracji ich obywateli.

Polityka oszczędzania i ograniczania deficytów budżetowych równocześnie w wielu krajach prowadzi nieuchronnie w jednych do spowolnienia tempa wzrostu a w innych, szczególnie silnie ograniczających wydatki, jak Grecja, Włochy, Hiszpania, do recesji. Odnotowano więc kilkuletnie spowolnienie rozwoju gospodarki krajów najbardziej rozwiniętych. Nie były w stanie temu zaradzić banki centralne, luzujące politykę pieniężną. Popyt na kredyt ze strony zarówno gospodarstw domowych, jak i przedsiębiorstw słabnie. Te pierwsze w fazie spowolnienia, często już silnie zadłużone, liczą się z niepewnością pracy i płac, w warunkach słabnącej koniunktury, a te drugie w stanie recesji, nie podejmują ważnych inwestycji ze względu na niski popyt i niezbyt zachęcające perspektywy jego wzrostu. Anemiczny wzrost gospodarczy nie przynosi więc wzrostu zatrudnienia i zmniejszania bezrobocia. 


\subsection{Mechanizm rynkowy a potrzeba zmniejszenia bezrobocia}

Gdy wzrost gospodarczy nie jest w stanie zapewnić możliwie pełnego zatrudnienia, nie można stosować bez końca zasad gospodarki liberalnej, podtrzymywać reguły konsensusu waszyngtońskiego, a więc rygorystycznej polityki pieniężnej, niewielkiego rządu i niskich podatków, elastycznego prawodawstwa pracy, deregulacji, prywatyzacji i całkowitego otwarcia rynków. Nie ma jednego cudownego środka na każdy stan gospodarki.

Ekonomiści neoliberalni, do niedawna głównego dominującego nurtu makroekonomii, powtarzają jak mantrę: „aby ożywić gospodarkę trzeba zmniejszyć podatki i uelastycznić zatrudnienie". Powtarzają to zarówno w sytuacji dobrej koniunktury sprzed kryzysu, jak i w czasie kryzysu i w warunkach pokryzysowego spowolnienia rozwoju, czy wręcz depresji. Oczekują w odmiennych warunkach rozwoju zawsze tych samych pożądanych rezultatów. Oznacza to nie tylko wierność regułom konsensusu waszyngtońskiego, lecz także jego pogłębienie, a więc więcej umów potocznie nazywanych śmieciowymi dla pracowników, niższe koszty pracy, niższe wynagrodzenia minimalne, bo przecież płace to koszty, które należy obniżać. Wynagrodzenia menedżerów są natomiast ceną zarządzania aktywami i są uzależnione od ich wartości rynkowych (Ratajczak, 2012).

A więc w przypadku menedżerów obowiązuje dobra cena za dobry towar. Płace pracowników są tylko kosztem i jak każdy rodzaj kosztów muszą być ograniczane nawet wtedy, gdy marże zysku rosną a akumulacja finansowa nie jest wydawana na inwestycje, lecz gromadzona w formie płynnych aktywów. Premie menedżerów nie są wydane na konsumpcję, a niepodzielone zyski korporacji na inwestycje uszczuplają popyt wewnętrzny. Wzrost aktywów płynnych pogłębia proces finansyzacji gospodarki, odrywa sferę finansów od sfery realnej.

Mówiąc o potrzebie działania wychodzącej poza zasady wynikające z konsensusu waszyngtońskiego, nie chcemy sugerować odstępstwa od zasad gospodarki rynkowej.

Doświadczenie historyczne dowodzi, że działanie „niewidzialnej ręki” rynku jest w wielu przypadkach sposobem sprawdzonym na zaspokajanie potrzeb społeczeństwa. Ceny kształtujące się na rynku odzwierciedlają zarówno wartość dobra czy usługi dla nabywcy (społeczeństwa), jak i koszt tego dobra lub usługi dla producenta-dostawcy (również społeczeństwa). Kierując się ceną rynkową bierzemy pod uwagę korzyści i koszty swych działań. Cytując popularny podręcznik: „cena tak wpływa na decyzje pojedynczych przedsiębiorstw i gospodarstw domowych, że zachowują się one w sposób, który w wielu przypadkach oznacza maksymalizacje dobrobytu społeczeństwa jako całości” (Mankin, Taylor, 2009, s. 40). 
Ważne jest tu podkreślenie słów „w wielu przypadkach”. Mechanizm rynkowy wpływa na wielkość PKB, a tym samym na dobrobyt społeczeństwa w takim stopniu, w jakim jest on zależny od produktu w przeliczeniu na jednego mieszkańca. Zgodnie z logiką wywodu, jeżeli więc naruszamy działania mechanizmu rynkowego, choćby przykładowo przez nakładanie podatków, to działamy szkodliwie na rynkową alokacje zasobów. Zakłócając mechanizm tworzenia cen równowagi, niweczymy tym samym przynajmniej w części efekty działania „niewidzialnej ręki”. Tym bardziej gdybyśmy zechcieli regulować ceny, na przykład żywności czy czynszów.

Jest tu pewna niekonsekwencja w założeniu. Niewidzialna ręka może być skuteczna tylko wtedy, gdy działa państwo i skutecznie egzekwuje. Państwo bowiem tworzy prawo, wymusza jego przestrzeganie i zapewnia bezpieczeństwo, a to jest głównym warunkiem działania rynku. Na samym początku doktryny wolnego rynku istnieje potrzeba oddzielenia maksimum produktu, którą umożliwia rynkowa wycena dóbr i rynkowa alokacja, od dobrobytu, w którym mieści się nie tylko wartość produktów, lecz także bezpieczeństwo, ład i porządek publiczny osiagany kosztem podatków.

Ponadto, jak wiadomo, trzeba uwzględniać:

- niedoskonałość alokacji rynkowej zasobów, zwłaszcza w zakresie infrastruktury materialnej i społecznej (zdrowie, nauka);

- nieuwzględnianie efektów zewnętrznych, a więc uboczne skutki działania jednych osób wpływające ujemnie na dobrobyt osób postronnych;

- niekorzystne następstwa przewag monopolowych na wycenę zasobów i dobrobyt innych.

Nie wymaga szerokiego wywodu twierdzenie, że dobrobyt nie jest tożsamy z wysokością PKB w przeliczeniu na jednego mieszkańca, choć jest zależny od wielkości PKB. Wymienione wyżej niedoskonałości działania rynku pośrednio to potwierdzają. Trzeba tylko podkreślić duże inne okoliczności pogłębienia tej różnicy między wielkością produktu a dobrobytem czy jakością życia.

Po pierwsze, zaspokojenie podstawowych potrzeb materialnych na wysokim poziomie - współczesny masowy konsument ma takie potrzeby, jakie wymyśli producent, a następnie je w konsumencie rozbudzi. Takie działanie nie jest złe, ponieważ najczęściej poprawia komfort życia człowieka i konsumenta. Rośnie jednak ilość nadużyć wynikających z przewagi producenta nad konsumentem. Ta nierówność pogłębia różnicę między wielkością produktu na mieszkańca a dobrobytem, przyczyniając się zarazem do niepotrzebnie wysokiego zużycia zasobów nieodnawialnych i szkód środowiska naturalnego.

Po drugie mechanizm rynkowy może stwarzać i pogłębiać nierówności społeczne, prowadzić do głębokiej stratyfikacji dochodowej. Problem ten od dawna jest szeroko dyskutowany i budzi liczne kontrowersje. Jedni przeciwstawiają efektywność egalitaryzmowi społecznemu, inni z kolei dowodzą potrzebę szer- 
szego rozumienia efektywności systemu społecznego, w którym nierówność szans jest kumulatywnie zwiększana przez nierówność dochodów o ujemnych skutkach dla rozwoju, również w rozumieniu ekonomicznym.

Przykładem nieefektywności rynku jest też bezrobocie, choć ekonomiści neoliberalni są gotowi widzieć tu winnych po stronie działań państwa czy nadmiernej siły związków zawodowych.

Wzrost gospodarczy, a zwłaszcza anemiczny, w warunkach wolnego rynku nie musi prowadzić do zmniejszenia bezrobocia, a wręcz przeciwnie nawet do jego zwiększenia. Nie chodzi tu bynajmniej jedynie o wpływ postępu technicznego na wielkość zatrudnienia, jak choćby nagłośniony przed laty przez Jeremy Rifkina (2003) problem wzrostu bezrobocia wywołanego przez szybki wzrost produktywności pracy. Chodzi również o wspomnianą wcześniej dezindustrializację krajów wysoko rozwiniętych na rzecz nowych rynków, nieprzystosowania zasobów siły roboczej w krajach zachodnich do nowej pracy w sektorach wysoko zaawansowanych.

Nieuchronnie narasta więc problem ludzi zbędnych w świetle reguł gospodarki rynkowej. Ludzie zbędni nie tworzą produktu krajowego. Osoby tracące prace czasowo $\mathrm{w}$ wyniku procesu histerezy pozostają w znacznej liczbie bez pracy na trwałe. Zbędne maszyny przeznacza się na złom. Zbędna siła robocza powinna być zagospodarowana i wykorzystana dla poprawy dobrobytu w sposób poza rynkowy, jeśli rynek nie potrafi jej włączyć w proces tworzenia PKB.

\subsection{Konieczność przywrócenia polityki sektorowej}

Aby osiągnąć stan zbliżony do pełnego zatrudnienia należy postawić $\mathrm{w}$ polityce gospodarczej państwa na sektory tworzące miejsca pracy, nawet wtedy, gdy efekt rynkowy jest ujemny. Dzieje się tak gdy przychody nie pokrywają kosztów, czy wręcz występuje nawet brak przychodów, ale zatrudnieni przyczyniają jednak się do wzrostu dobrobytu niewymiernego w kategoriach rynkowych.

Jest już zapewne zbyt późno na przywrócenie polityki przemysłowej i tworzenie miejsc pracy przez protekcyjne wspieranie rozwoju przemysłu. Nie pozwala na to wysoki stopień integracji gospodarki narodowej z gospodarką światową, przynależność do Światowej Organizacji Handlu (WTO), Unii Europejskiej oraz zobowiązania wynikające $\mathrm{z}$ innych porozumień międzynarodowych. W tych okolicznościach należy wykorzystać sektory niekomercyjne, jak oświata, zdrowie, nauka i kultura. Ważna jest także polityka prorodzinna i rozwój sektora opieki nad małymi dziećmi.

Polityka sektorowa jest trwałym elementem gospodarek rynkowych zaawansowanych w rozwoju. Przykładem jest polityka rolna doceniana w większości państw. Dynamiczny rozwój sektora drugiego, to jest przemysłu i budownictwa 
pozwalał na pozostawienie nieefektywnego rolnictwa. Wymowny przykład pod tym względem stanowiła Japonia w fazie najbardziej dynamicznego rozwoju, rozwijająca silny sektor eksportowy przemysłu z pozostawieniem wielkich obszarów nieefektywności w rolnictwie i usługach.

Obecnie głośna jest sprawa sektora handlu wewnętrznego w Indiach. Planowane przez rząd otwarcie handlu dla hipermarketów zagraża drobnemu handlowi, który daje miejsca pracy dla 220 mln Hindusów, stąd silne protesty w jego obronie.

Sektory niekomercyjne gospodarki, które wymieniliśmy jako miejsca dodatkowego zatrudnienia dla rozładowania napięć na rynku pracy związanych z bezrobociem nie są reliktem gospodarki tradycyjnej. Mogą one stać się elementem trwałym, czy nawet wiodącym, w gospodarce. Powstała obszerna literatura poświęcona znaczeniu oświaty, nauki, ochrony zdrowia czy też zdrowych proporcji demograficznych dla rozwoju społeczno-gospodarczego w długim okresie. Problem jest w tym, że obecnie wysiłki na rzecz oszczędzania, związane z kryzysem finansów publicznych, przynoszą działania rządów dokładnie w odwrotnym kierunku. Są to przede wszystkim cięcia wydatków budżetowych. Dotyczy to również tej części, która jest przeznaczona między innymi na zdrowie, oświatę, naukę i kulturę, przyczyniając się do zwiększenia bezrobocia.

Rządy w niewielkim tylko stopniu i nie wszystkie decydują się na podwyższenie podatków dla zrównoważenia budżetu, zwłaszcza podatków od dochodów. Odwrócenie obecnej polityki jest możliwe i pożądane choć nie będzie łatwe i szybkie. Przesądzić o tym mogą czynniki polityczne, zachodzi konieczność zdjęcia „Złotego Kaftana Bezpieczeństwa”.

„Złotym Kaftanem Bezpieczeństwa” Thomas Friedman nazwał strategię rządów, które rygorystycznie wdrażają strategię zgodną z konsensusem waszyngtońskim, a więc zdrowy pieniądz, niskie podatki, elastyczne prawodawstwo pracy, prywatny i wolny handel, licząc na zaufanie rynków, które pozwoli na przyciągnięcie kapitału, pozyskanie łaskawości funduszy inwestycyjnych i dobrych opinii agencji ratingowych (za: Rodrik, 2011). „Kaftan” zawęża tym samym obszar działania rządów w dziedzinie polityki gospodarczej.

Wierność tym zasadom, dobra opinia i zaufanie rynków są rekomendacją polityczną dla rządów. $\mathrm{Z}$ tych zasad nie będzie też rezygnować opozycja gdy dojdzie do władzy. W związku z tym polityka jest zgodna z oczekiwaniami rynków oraz własnych elit finansowych, a niekoniecznie - o czym wspomnieliśmy wyżej - z celami i aspiracjami całego społeczeństwa. Rządy mają wystarczająco mocne argumenty (a może dokładniej: alibi), aby taką politykę kontynuować.

Polityka sektorowa, stawiająca na rozwój niekomercyjnych usług publicznych, finansowanych $\mathrm{z}$ budżetu państwa i to ze środków uzyskanych z podatków, a nie metodą „państwa przyjaznego”, oznacza rezygnację z tego stroju obronnego. 
Za odstąpieniem od tej jednostronnej i w istocie oportunistycznej polityki na rzecz polityki uwzględniającej rozwój sektora usług publicznych przemawiają - w naszym przekonaniu - ważne argumenty.

1. Nie ma dowodów na to, że obniżka podatków od dochodu, zwłaszcza zmniejszenie progresji podatkowej przyniesie wzrost zatrudnienia. Tak samo jak nie ma dowodów na to, że wyższe podatki dochodowe i większa progresja hamuje przedsiębiorczość i innowacyjność. Badania statystyczne tych zależności w obu przypadkach dają wyniki niejednoznaczne. Oznacza to, że w przypadku kryzysu finansów publicznych najlepszym sposobem ich uzdrowienia nie jest cięcie wydatków na usługi publiczne, które zmniejszą popyt krajowy i pogłębią recesję. Lepszą drogą jest wzrost wpływów podatkowych, zwłaszcza z podatku od dochodów. Nie znaczy to oczywiście, że można zaniedbywać racjonalizację wydatków na usługi publiczne.

2. Nakłady na rozwój i odpowiednią jakość żłobków, przedszkoli, szkół, a także na pomoc matkom pracującym zawodowo i rodzinom wielodzietnym są lepszą inwestycją niż inwestowanie na giełdzie środków funduszy emerytalnych. Duża liczba zdrowych i dobrze wykształconych przyszłych pracowników jest bardzo dobrym zabezpieczeniem przyszłych emerytur. Podobnie jest z polityką prenatalną.

3. Wiele argumentów przemawia za działaniem na rzecz rozwoju i zmian jakościowych w szkolnictwie publicznym. Podniesienie poziomu szkół publicznych jest warunkiem lepszego wyrównywania szans młodzieży. Szkoły wszystkich szczebli, w tym również szkoły wyższe formują najważniejszy czynnik przyszłego rozwoju: kapitał ludzki. Oczywiście zwiększone nakłady na ten cel muszą być wsparte przemyślaną organizacją i zarządzaniem.

4. Nakłady na ochronę zdrowia i opiekę nad osobami starymi rosną wydatnie we wszystkich krajach, również w tych, które kierują się w polityce gospodarczej zasadami neoliberalnymi. Zmusza do tego proces starzenia się społeczeństw krajów wysoko rozwiniętych, jak też i postęp technologii medycznych, wdrażany w służbie zdrowia i z reguły kosztowny. System ochrony zdrowia i opieki nad chorymi i niepełnosprawnymi stwarza wyjątkowo duże pole dla uzasadnionego społecznie wzrostu zatrudnienia.

5. Dużym polem aktywności zawodowej może być także animacja kultury, rekreacji i sportu. Większe i mądrze wydawane środki publiczne na ten cel mogą przynieść efekty podobne, jak nakłady na szkolnictwo, naukę i ochronę zdrowia w dłuższym okresie. Wywierać będą one korzystny wpływ na kształtowanie kapitału ludzkiego i kapitału społecznego.

6. Nakłady na usługi i świadczenia ze środków publicznych przyczyniają się, jak twierdzimy, do dobrobytu i jakości życia społeczeństwa nieznajdującego wyrazu we wskaźniku produktu krajowego. Przyczyniają się one w długim okresie również do wzrostu produktu krajowego. Niestety, efekty w sensie 
wąsko ekonomicznym pojawią się w przyszłości, a nakłady trzeba ponosić obecnie. Nakłady te są jednak konieczne zarówno dla poprawy dobrobytu, jak i dla uniknięcia napięć społecznych i konfliktów, które może zrodzić utrzymujące się wielkie bezrobocie, zwłaszcza wśród młodzieży, jak również z powodu niebezpiecznego wzrostu nierówności społecznych. Bieda i wykluczenie nie będzie bezpiecznie koegzystować z rosnącym bogactwem i ostentacyjną konsumpcją elit. $\mathrm{Z}$ tych też powodów niezbędne jest zmniejszenie rozpiętości dochodowych przez system progresji podatkowej. Środki uzyskane z podwyższonych podatków powinny finansować zwiększone wydatki publiczne.

\subsection{Szanse polityki sektorowej i trylemat Daniego Rodrika}

Postulat sfinansowania programów aktywizacji zawodowej przez sektor publiczny gospodarki do niedawna był przedmiotem drwin ekonomistów głównego nurtu i wyznających ich poglądy polityków oraz opiniotwórczych środków masowego przekazu. Epitet głoszenia socjalizmu nie był tu epitetem najcięższym.

Do świadomości publicznej dociera skala rozpiętości dochodowych i wzrost tych rozpiętości w całym okresie neoliberalnej fazy rozwoju kapitalizmu, począwszy od połowy lat siedemdziesiątych ubiegłego wieku. Wzrost tych rozpiętości nie ustał w okresie kryzysu. Społeczeństwa coraz bardziej zdają sobie sprawę ze skutków symbiozy elit politycznych i finansowych, zamienności karier w biznesie i w polityce, roli lobbystów w stanowieniu prawa itp. Związki polityki i biznesu sprzyjają ochronie wysokich dochodów przed redystrybucją w imię wspierania wzrostu gospodarczego, co mija się z rzeczywistością.

Świadomość takiego stanu jest warunkiem niezbędnym do jego zmian, lecz tylko pierwszym krokiem w tym kierunku. Świadomość ta zrodziła ruch oburzonych, który w tym wypadku nie ma większego znaczenia, poza efektem medialnym. Największy problem ewentualnych zmian wynika ze skali międzynarodowej integracji gospodarczej i z finansjeryzacji gospodarki światowej oraz owego „złotego kaftana bezpieczeństwa”.

W warunkach swobody przepływu kapitału wyegzekwowanie płatności podwyższonych podatków dochodowych dla płatników o najwyższych dochodach może spowodować ucieczkę podatników. Nie jest to niestety tylko sprawa ucieczki podatników, czy przenoszenia strat zysku z powodu płaconego podatku, na klientów w przypadku podmiotów będących w pozycji monopolistycznej. Szerzej tę sprawę ilustruje trylemat Daniego Rodrika, który przedstawiamy $\mathrm{z}$ nieco zmienionym opisem na rysunku 4.1. 
Rysunek 4.1. Trylemat Daniego Rodrika

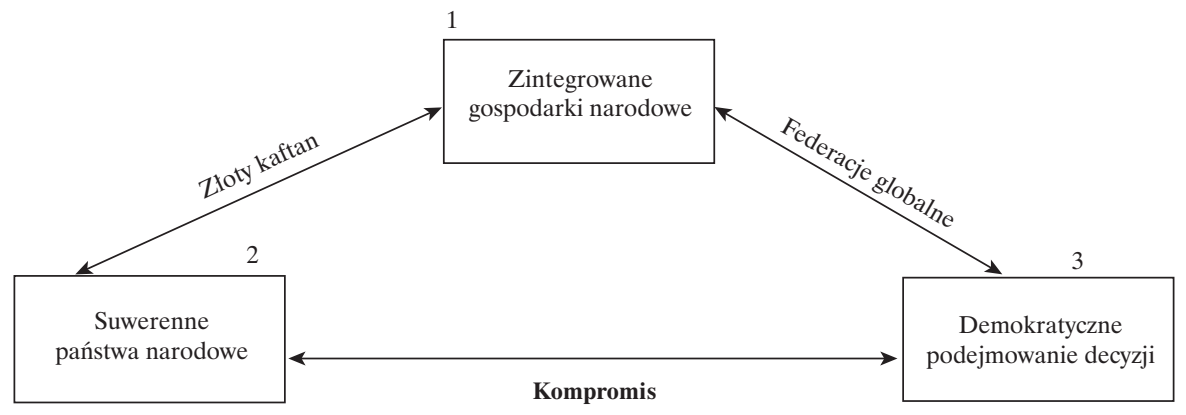

Źródło: opracowane na podstawie: Rodrik, 2011, s. 265.

Podobnie jak w przypadku trylematu gospodarki otwartej w terminologii Obstfelda i Taylora występuje tzw. niemożliwa trójca: (1) międzynarodowa mobilność kapitału; (2) sztywny kurs walutowy regulowany przez państwo; (3) autonomiczna polityka pieniężna rządu. Możliwa jest koegzystencja dwu $\mathrm{z}$ trzech okoliczności.

Jeśli mamy do czynienia z międzynarodową mobilnością kapitału, w której kraj uczestniczy (1) to może posiadać tylko jedną z dwu swobód: swobodę kształtowania kursu walutowego (2) lub swobodę polityki pieniężnej (3). Jeśli natomiast chcemy mieć zarówno swobodę stanowienia kursu walut, jak i swobodę polityki monetarnej musimy położyć kres swobodzie przepływu kapitału.

Podobnie jest w trylemacie Rodrika, jeśli przynależymy do zintegrowanej gospodarki światowej (1) i posiadamy suwerenne państwo narodowe (2) to nie możemy oczekiwać, że decyzje w gospodarce będą podejmowane w następstwie procedur demokratycznego wyboru w tym państwie (3). Wybór następuje pod dyktando „światowej federacji”, która formalnie nie istnieje, lecz tworzą ją międzynarodowe instytucje, w których uczestniczymy (jak na przykład Międzynarodowy Fundusz Walutowy czy Bank Światowy), a przede wszystkim rynki kapitałowe.

W świetle tego trylematu swoboda ucieczki podatkowej przed „pazernym rządem" nie jest jedyną i najważniejszą przeszkodą przy podnoszeniu podatków dla najbogatszych. Ważna jest także opinia owej „federacji”, a więc rynków finansowych o rządzie, który podejmuje tego typu decyzje. Rządy mogą być i są karane za „złe obyczaje” w stosunku do elit finansowych, tak samo jak za rozrzutność i niewystarczające oszczędności. Dotkliwą karą jest odmowa funduszy inwestycyjnych finansowania długu publicznego, wymuszająca w konsekwencji ustąpienie rządów. Odnosi się to również i do państw nie nazbyt silnie zadłużonych. Tego typu zależność suwerennych państw narodowych od zachowań 
rynków sprzyja utrwalaniu silnego zróżnicowania dochodów i wzrostowi finansyzacji gospodarki i przyczynia się do pogłębiania nierówności dochodowych wewnątrz państw.

Interpretacja trylematu Rodrika pozwala jednak na dostrzeżenie szans na zmiany. „Złoty kaftan bezpieczeństwa” będzie zapewne z czasem stawał się zbyt ciasny, a wyroki międzynarodowych rynków nie będą przyjmowane $\mathrm{z}$ taką jak teraz pokorą przez rządzące elity.

Dani Rodrik, pisząc o ograniczeniu dostępu do decyzji politycznych na poziomie narodowym, powołuje się na analogię poprzedniej integracji gospodarczej z okresu standardu złota w systemie monetarnym państw. „W szczytowych czasach standardu złota ograniczona domena polityki narodowej (i charakterystyczne dla niej oparcie się na elitach) zapewniała, że wewnętrznie polityka monetarna mogła być całkowicie podporządkowana potrzebom utrzymania parytetu złota.

W okresie międzywojennym, gdy prawa wyborze zostały rozszerzone na wszystkich, a robotnicy się zorganizowali, rządy narodowe odkryły, że nie mogą już dłużej utrzymywać ekonomicznej ortodoksji standardu złota. Kiedy potrzeby pełnego zatrudnienia zderzyły się z potrzebami standardu złota, ten ostatni ustąpił miejsca" (Rodrik, 2011, s. 268).

Ten cytowany przykład jest groźnym ostrzeżeniem dla losów międzynarodowej integracji i zglobalizowanej gospodarki. Wiemy bowiem co nastąpiło po rozpadzie standardu złota. Rozpad częściowy systemu Bretton Woods nie był tak groźny, dzięki zapewne „dobroczynnej hegemonii” Stanów Zjednoczonych Ameryki i dolara amerykańskiego (za: Hellainer, 2011, s. 268). Nowy porządek został oparty już nie na złocie, lecz na zaufaniu rynków do Ameryki i jej waluty.

Podobnie i w tym wypadku można mieć nadzieję, że wyrwanie się z więzów trylematu nie będzie następstwem buntu robotniczego, czy też protestów oburzonych, lecz buntem elit rządowych, który pozwoli na wprowadzenie międzynarodowych ustaleń i rozsądnego kompromisu dla okiełznania dyktatu rynków.

Jeśli progresywny system podatkowy przyczyni się do wzmocnienia finansów publicznych i jednocześnie zmniejszenia rozpiętości dochodów, wtedy mogą wziąć górę zalety podatków pośrednich. Dzięki podatkom nakładanym na konsumpcję, można będzie podnosić poziom życiowy społeczeństw przy mniejszym zapotrzebowaniu na zasoby nieodnawialne przyrody i mniejszej degradacji środowiska naturalnego.

Obecne podwyżki VAT i innych podatków pośrednich w poszczególnych krajach są demonstracją owego „złotego kaftana bezpieczeństwa”, a mówiąc kolokwialnie wyrazem oportunizmu rządzących. Podatek ten jest łatwiejszy do wprowadzenia ze względów politycznych. Jednak zmniejszanie realnych dochodów i popytu konsumpcyjnego części mniej zamożnej społeczeństw, osłabia ożywienie gospodarki i przyczynia się do pogłębiania stratyfikacji dochodowej. 
Sprawą najbardziej kontrowersyjną jest rola państwa narodowego i jego polityki. Powyższe rozważania wskazują na potrzebę zwiększenia roli państwa w gospodarce. Zdajemy sobie sprawę zarówno z zalet, jak i wad „małego” państwa tak samo, jak z zalet i wad wolnego rynku. Zbiurokratyzowane wszechmogące państwo jest tak samo nie do przyjęcia, jak całkowicie wolny rynek.

Nikt dotychczas nie skodyfikował reguł państwa złotego środka. Francis Fukuyama (Stasiński, 2012) z reguły śmiało wypowiadający się o teraźniejszości i przyszłości mówi, że istnieje potrzeba wymyślenia państwa na nowo, lecz on jest za mało bystry, aby przewidzieć jak ma to państwo wyglądać.

Przed obecnym kryzysem zbyt wiele władzy pozostawiono rynkowi. Obecnie widać, że proces wycofywania się państwa i rosnącej dominacji rynku należy na nowo przemyśleć częściowo zrewidować, ale też powrót państwa uważnie kontrolować. Jest to zadanie dla opinii publicznej w tym także, a może przede wszystkim, dla nauk ekonomicznych i zarządzania.

\section{Bibliografia}

Buras, P. (2012). Ulica zmieni świat (wywiad z Wolfgangiem Streeckiem). Gazeta Wyborcza, 5-6 maja.

Hellainer, E. (2011). Globalne ekonomie polityczne. Kraków: Wydawnictwo Uniwersytetu Jagiellońskiego.

Mankin, N.G., Taylor, M.P. (2009). Mikroekonomia. Warszawa: Polskie Wydawnictwo Ekonomiczne.

Mess, H. (2012). Forum z 13 września.

Ratajczak, M. (2012). Finansyzacja gospodarki. Ekonomista, (3).

Rifkin, J. (2003). Koniec pracy. Schyłek sity roboczej na świecie i początek ery postrynkowej. Wrocław: Wydawnictwo Dolnośląskie.

Rodrik, D. (2011). Jedna ekonomia, wiele recept. Warszawa: Wydawnictwo Krytyka Polityczna. Rzeczpospolita (2012), 18 września.

Stasiński, M. (2012). Państwo sztywne jak fabryka Forda (wywiad z Francisem Fukuyamą). Gazeta Wyborcza, 2-3 czerwca. 


\title{
Rozdział 5 \\ Zagadnienia ryzyka na międzynarodowych rynkach finansowych*
}

\begin{abstract}
Streszczenie
W ostatnich trzech dekadach rynki finansowe doznały bezprecedensowej transformacji, której pierwsze symptomy można było zauważyć w końcu lat 70. XX wieku. Formalnym przejawem transformacji rynków finansowych w latach 80 . XX wieku było wprowadzenie deregulacji. Skutkami tego procesu była integracja rynków finansowych, przyczyniająca się do nasilającej się ich konkurencyjności (skutkującej sukcesywnym pojawianiem się innowacji finansowych). Dynamiczny rozwój technologii informatycznych i telekomunikacyjnych w latach 90. XX wieku oraz pierwszej dekady XXI wieku przyczynił się do liberalizacji i umiędzynarodowienia rynków finansowych, co doprowadziło do ich hiperglobalizacji, czego skutkiem jest zwiększenie rozmiaru rynków finansowych i totalna ich integracja. Koniec lat 90. XX wieku charakteryzował się również dynamicznym rozwojem inwestycji transgranicznych, głównie pomiędzy USA a Europą Zachodnią i w mniejszym stopniu Japonią. W ostatnich latach na światowych rynkach giełdowych dochodziło do potężnych procesów konsolidacyjnych (największe giełdy przejmowały mniejsze). W konsekwencji obrót giełdowy stał się bardziej skoncentrowany. W 2011 roku 75\% światowych obrotów akcjami dokonywanych było na kilku największych giełdach (NYSE, LSE, Euronext, Tokyo SE) (www.world-exchange.org). Efektem omawianych procesów jest globalna skala skutków wydarzeń i zjawisk na poszczególnych rynkach, co zwiększyło poziom ryzyka rynkowego. W literaturze przedmiotu zagadnienie ryzyka na rynkach giełdowych było analizowane wieloaspektowo. W niniejszym artykule przedstawiamy wyniki badań kształtowania się poziomu ryzyka rynku akcji pięciu wiodących giełd: NYSE, LSE, Euronext, Deutsche Börse, Tokyo SE w okresie 1950-2012. Przyjętą miarą ryzyka jest wielkość odchylenia standardowego rozkładu realnych stóp zwrotu przypadająca na jednostkową stopę zwrotu. Poziomy ryzyka zostały wyznaczone dla horyzontów inwestycyjnych od roku do 30 lat. Do badań użyto
\end{abstract}

\footnotetext{
Współautor - prof. ALK dr hab. Tadeusz Winkler-Drews, Katedra Bankowości Ubezpieczeń i Ryzyka Akademia Leona Koźmińskiego w Warszawie. Na podstawie The Disc of Holding Periods Acros International Stocks. W: International Journal of Business, 2015.
} 
miesięcznych danych bazy Global Financial Data. Zjawiska i tendencje zanalizowane w tym artykule w latach 1950-2012 występują nadal pod koniec drugiej dekady XXI wieku. Dlatego zasadnicze oceny i konkluzje zawarte w tym artykule są jak najbardziej aktualne.

Słowa kluczowe: rynki finansowe, czołowe giełdy finansowe, indeksy giełdowe, poziomy ryzyka, inwestycje transgraniczne, procesy konsolidacji, liberalizacja, umiędzynarodowienie.

\section{Risk Issues in International Financial Markets}

\section{Summary}

Over the past three decades, financial markets have experienced an unprecedented transformation, the first symptoms of which could be seen in the late 1970s. The introduction of deregulation was a formal manifestation of the transformation of financial markets in the 1980s. The integration of financial markets contributed to the growth of their competitiveness (resulting in the successive emergence of financial innovations). The dynamic development of information and telecommunications technologies in the 1990s and in 2020s contributed as well to the hiperliberalization and internationalization of financial markets. The end of the 1990s was also characterized by a dynamic development of cross-border investments, mainly between the USA and Western Europe and, to a lesser extent, Japan. The massive consolidation processes have taken place in the global stock markets (the largest stock exchanges were taken over by smaller ones). As a consequence, stock exchange trading has become more concentrated. In 2011, 75\% of the world's stocks traded on several major stock exchanges (NYSE, LSE, Euronext, Tokyo SE) (www.world-exchange.org). The effect of the discussed processes is the global scale of the effects of events and phenomena on individual markets, which increased the level of market risk. In the literature on the subject, the issue of risk on the stock markets has been analyzed in many aspects. In this article, we present the results of research on the risk level of the stock market in five leading financial exchanges: NYSE, LSE, Euronext, Deutsche Börse, Tokyo SE, in the period 1950-2012. The adopted measure of risk is the size of the standard deviation of the distribution of real rates of return per unit rate of return. The risk levels have been set for investment horizons from 1 to 30 years. Monthly Global Financial Data was used for the research. The phenomena and tendencies analyzed in this article in the years 1950-2012 still occur at the end of the second decade of the 21st century. Therefore, the fundamental assessments and conclusions contained in this article are as up to a date as possible.

Keywords: financial markets, leading financial exchanges, stock indices, cross-border investments, consolidation processes, liberalization, internationalization. 


\subsection{Rynek amerykański}

Wynikiem wzmocnienia gospodarki amerykańskiej w okresie II wojny światowej była znaczna przewaga ekonomiczna Stanów Zjednoczonych nad pozostałymi państwami kapitalistycznymi w okresie powojennym. Wyścig zbrojeń wywołany zimną wojną oraz wybuch wojny koreańskiej dały nowy impuls (boom koreański) - w latach 1950-1953 (produkcja przemysłowa USA wzrosła o 41\%). Zakończenie wojny koreańskiej spowodowało spadek wydatków budżetowych, co wywołało krótkotrwałą recesję (1953-1954). Wzrost inflacji w USA przyczynił się do kolejnej recesji (1957-1958). Stymulatorem wysokiego tempa wzrostu gospodarczego USA latach 50. XX wieku była rosnąca produkcja przemysłowa. W latach 60 . XX wieku napęd gospodarki stanowity zaś nakłady na badania naukowe i wdrożeniowe w przemyśle, stymulowane wyścigiem gospodarczym, związanym z wyścigiem zbrojeń. Nakłady na: wdrażanie programu „Nowa Ekonomika”, eksplorację kosmosu czy wojnę wietnamską spowodowały deficyt budżetowy oraz wzrost inflacji. Od 1969 roku głównym celem była walka $\mathrm{z}$ inflacją - odejście od keynesizmu na rzecz monetaryzmu, jednak działania te nie dały efektów i w 1970 roku zaczęła się stagflacja. W latach 1950-1973 gospodarka amerykańska rozwijała się w tempie: PKB $3,9 \%$; produkcja przemysłowa 5,3\%; inflacja 2,7\%. Pierwszy kryzys naftowy (1974-1975) spowodował spowolnienie dynamiki gospodarki; wzrost bezrobocia i inflacji wywołał stagflację. Podjęto więc walkę z recesją w duchu monetarystycznym. W 1977 roku prezydent Jimmy Carter zapoczątkował szereg programów o charakterze socjalnym, co tylko pogorszyło sytuację (w 1980 roku inflacja wyniosła 13,5\%). W 1981 roku Ronald Reagan wprowadził deregulację, zwiększono wydatki na zbrojenia „Gwiezdne wojny” (inflacja spadła do 6,2\%). W 1982 roku spadek cen ropy naftowej obniżył inflację do 3,2\%, co spowolniło wzrost gospodarczy. Zapoczątkowane w 1983 roku przyspieszenie gospodarcze utrzymało się - w 1990 roku PKB rósł średnio o 3,4\%. Innowacyjność wpłynęła na wzrost eksportu, ale nie zatrzymało to wysokiego deficytu płatniczego USA, które były największym dłużnikiem świata. Do tego dochodził ogromny dług wewnętrzny - w 1986 roku deficyt wynosił 200 mld USD (głównie na skutek programu „Gwiezdne wojny”). W latach 1974-1990 gospodarka amerykańska rozwijała się w tempie: PKB $-2,6 \%$; produkcja przemysłowa $-2,5 \%$; inflacja $-6,7 \%$. Wydatki na zbrojną interwencję w Kuwejcie w latach 1990-1991 osłabiły koniunkturę. W 2001 roku rozpoczęła się zbrojna interwencja w Afganistanie, w okresie 2003-2005 wojna w Iraku (szacowana na 802 mld USD), co spowolniło gospodarkę. W 2008 roku rozpoczął się kryzys subprime. Interpretację rynkową omawianych powyżej zjawisk gospodarczych prezentuje rysunek 5.1. 
Rysunek 5.1. Wartości indeksu DJIA i inflacji USA (1950-2012)

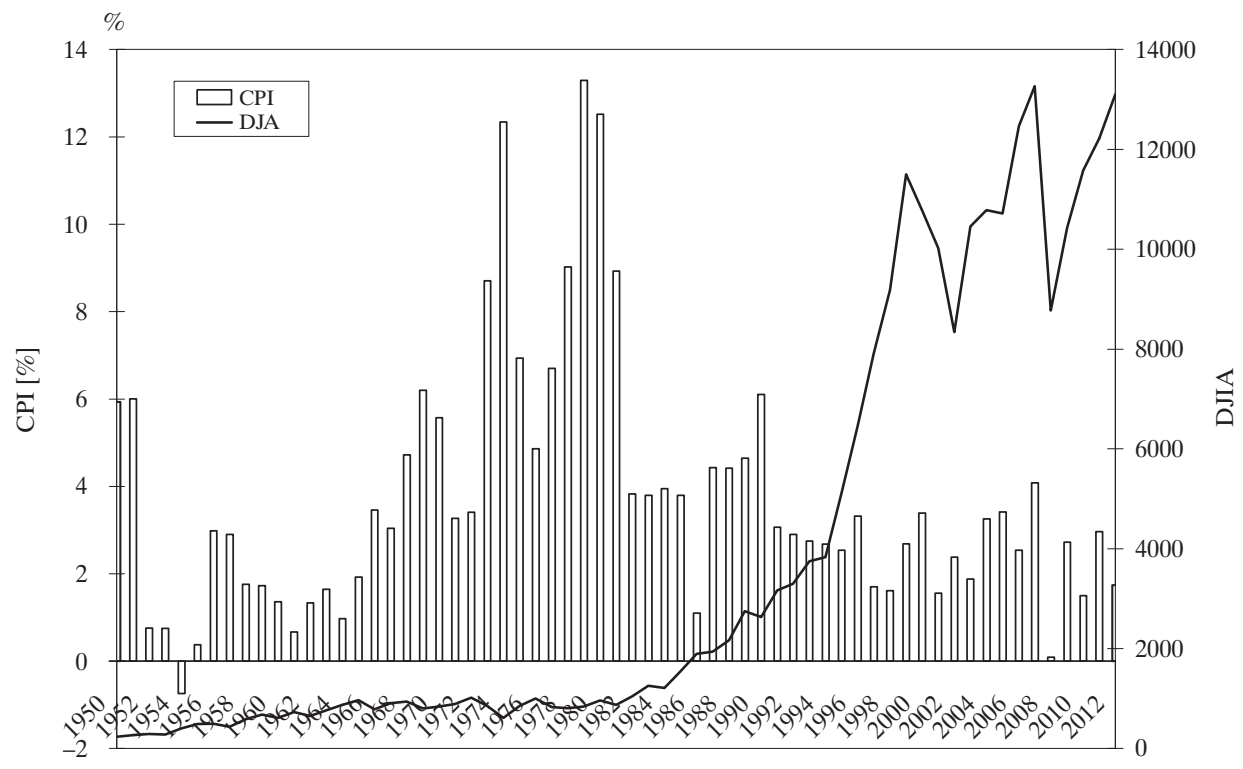

Źródło: opracowanie własne na podstawie: Global Financial Data.

Pomimo wydatków na wyścig zbrojeń, eksplorację kosmosu, programy socjalne, wojnę w Wietnamie, zainicjowany koniunkturą wojny koreańskiej wzrostowy trend gospodarki amerykańskiej utrzymał się do początków lat 70 . $\mathrm{XX}$ wieku, co znajduje potwierdzenie w koniunkturze giełdy nowojorskiej. Bardzo niekorzystne dla gospodarki amerykańskiej skutki obu kryzysów energetycznych oraz wydatki na "Gwiezdne wojny” nie zmieniły wzrostowego trendu giełdowego w latach 1973-1984. Rozwój sektora IT zdynamizował rozwój gospodarki amerykańskiej na przełomie lat 80 . i 90 . XX wieku, co przełożyło się również na dynamikę koniunktury giełdowej w okresie 1985-1994. Odwrócenie dynamicznego trendu wzrostowego nastąpiło w 1999 roku w wyniku kryzysu branży MTM, kolejny trend wzrostowy po 2002 roku został odwrócony na skutek kryzysu subprime. Charakterystyki rozkładów realnych stóp zwrotu indeksu DJIA prezentuje tabela 5.1. 
Tabela 5.1. Charakterystyki rozkładów realnych stop zwrotu indeksu DJIA

\begin{tabular}{|c|c|c|c|c|c|c|c|}
\hline \multirow{2}{*}{$\begin{array}{l}\text { Horyzont } \\
\text { inwestycyjny } \\
\text { (lata) }\end{array}$} & \multicolumn{3}{|c|}{ Stopa zwrotu } & \multirow{2}{*}{$\begin{array}{c}\text { Odchylenie } \\
\text { standardowe } \\
(\%)\end{array}$} & \multirow[b]{2}{*}{ Kurtoza } & \multirow[b]{2}{*}{ Skośność } & \multirow[b]{2}{*}{$\begin{array}{c}\text { Ilośćc } \\
\text { obserwacji }\end{array}$} \\
\hline & $\begin{array}{c}\underset{(\%)}{\operatorname{minimum}} \\
\end{array}$ & $\begin{array}{c}\text { maksimum } \\
(\%)\end{array}$ & $\begin{array}{c}\text { wartość } \\
\text { oczekiwana } \\
(\%)\end{array}$ & & & & \\
\hline 1 & $-42,67$ & 46,72 & 4,33 & 16,30 & $-0,130$ & 0,040 & 745 \\
\hline 2 & $-29,66$ & 37,28 & 3,60 & 11,61 & $-0,013$ & 0,131 & 733 \\
\hline 3 & $-18,16$ & 28,25 & 3,29 & 9,34 & $-0,450$ & 0,184 & 721 \\
\hline 4 & $-13,94$ & 22,91 & 3,11 & 8,25 & $-0,768$ & 0,216 & 709 \\
\hline 5 & $-12,08$ & 22,20 & 3,06 & 7,79 & $-0,756$ & 0,175 & 697 \\
\hline 6 & $-13,06$ & 18,20 & 3,00 & 7,19 & $-0,856$ & 0,005 & 685 \\
\hline 7 & $-11,19$ & 16,64 & 2,92 & 6,75 & $-1,035$ & $-0,051$ & 673 \\
\hline 8 & $-9,97$ & 15,14 & 2,87 & 6,44 & $-1,102$ & $-0,159$ & 661 \\
\hline 9 & $-9,99$ & 14,89 & 2,85 & 6,23 & $-1,051$ & $-0,292$ & 649 \\
\hline 10 & $-9,45$ & 13,17 & 2,77 & 5,98 & $-1,141$ & $-0,304$ & 637 \\
\hline 11 & $-8,45$ & 12,89 & 2,72 & 5,81 & $-1,209$ & $-0,265$ & 625 \\
\hline 12 & $-7,74$ & 12,47 & 2,70 & 5,62 & $-1,202$ & $-0,236$ & 613 \\
\hline 13 & $-8,13$ & 12,79 & 2,71 & 5,47 & $-1,076$ & $-0,233$ & 601 \\
\hline 14 & $-7,74$ & 12,97 & 2,71 & 5,30 & $-0,985$ & $-0,188$ & 589 \\
\hline 15 & $-7,58$ & 12,91 & 2,68 & 5,14 & $-0,929$ & $-0,138$ & 577 \\
\hline 16 & $-7,39$ & 12,48 & 2,62 & 4,96 & $-0,886$ & $-0,117$ & 565 \\
\hline 17 & $-6,97$ & 12,92 & 2,56 & 4,78 & $-0,914$ & $-0,081$ & 553 \\
\hline 18 & $-6,36$ & 11,71 & 2,48 & 4,60 & $-1,014$ & $-0,043$ & 541 \\
\hline 19 & $-5,25$ & 10,93 & 2,39 & 4,42 & $-1,122$ & $-0,004$ & 529 \\
\hline 20 & $-4,84$ & 9,96 & 2,32 & 4,20 & $-1,214$ & 0,015 & 517 \\
\hline 21 & $-4,84$ & 8,95 & 2,28 & 4,01 & $-1,326$ & 0,026 & 505 \\
\hline 22 & $-4,23$ & 8,94 & 2,22 & 3,84 & $-1,385$ & 0,085 & 493 \\
\hline 23 & $-4,36$ & 8,53 & 2,16 & 3,65 & $-1,403$ & 0,102 & 481 \\
\hline 24 & $-3,03$ & 8,20 & 2,11 & 3,44 & $-1,441$ & 0,138 & 469 \\
\hline 25 & $-3,05$ & 8,50 & 2,09 & 3,25 & $-1,381$ & 0,167 & 457 \\
\hline 26 & $-3,12$ & 7,95 & 2,09 & 3,08 & $-1,423$ & 0,174 & 445 \\
\hline 27 & $-2,70$ & 7,05 & 2,06 & 2,86 & $-1,521$ & 0,197 & 433 \\
\hline 28 & $-2,01$ & 6,70 & 2,02 & 2,64 & $-1,495$ & 0,270 & 421 \\
\hline 29 & $-1,67$ & 6,71 & 1,99 & 2,42 & $-1,403$ & 0,307 & 409 \\
\hline 30 & $-1,15$ & 6,62 & 1,98 & 2,19 & $-1,296$ & 0,398 & 397 \\
\hline
\end{tabular}

Źródło: opracowanie własne na podstawie: Global Financial Data. 
Wartości oczekiwanych stóp zwrotu dla 30-letniego horyzontu są ponad dwukrotnie mniejsze od wartości oczekiwanych stóp zwrotu dla horyzontu jednorocznego. Relacje wartości odchylenia standardowego dla analogicznych horyzontów są ponad siedmiokrotne. Wartości ryzyka względnego realnych oczekiwanych stóp zwrotu indeksu DJIA w zależności od długości horyzontu inwestycyjnego ilustruje rysunek 5.2.

Rysunek 5.2. Wartości ryzyka względnego indeksu DJIA

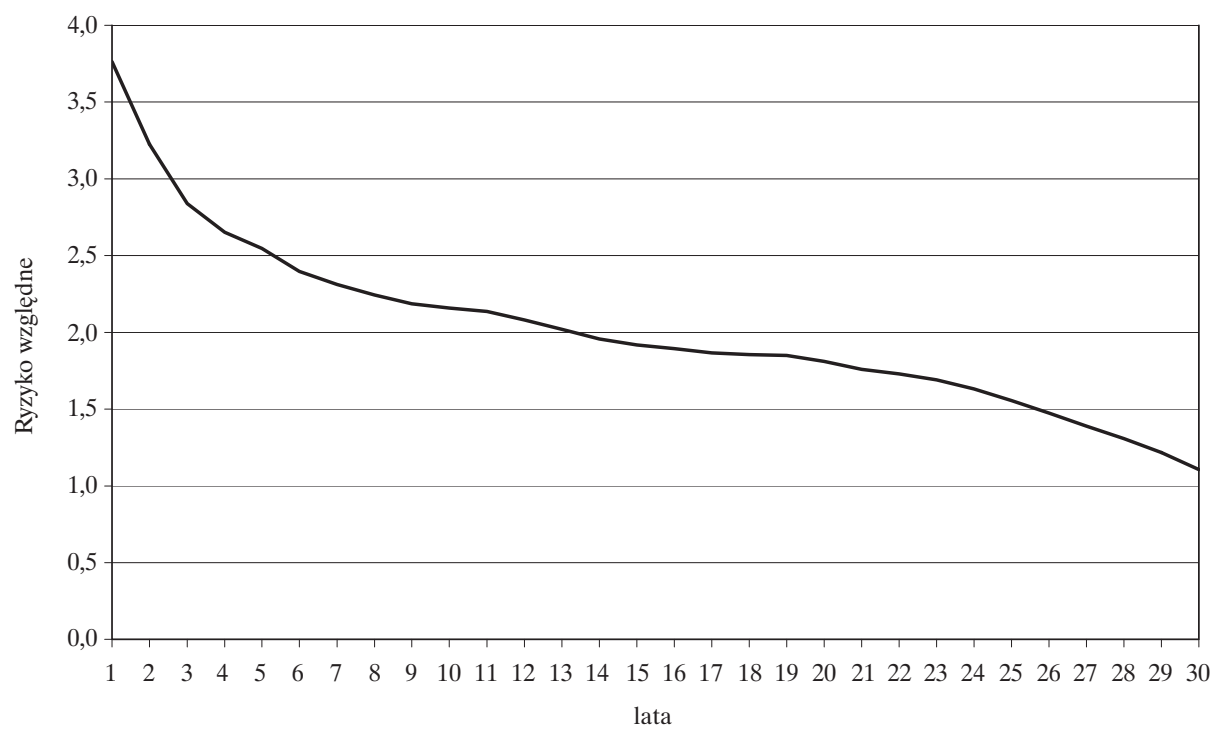

Źródło: opracowanie własne na podstawie: Global Financial Data.

Dynamikę ryzyka względnego realnych stóp zwrotu indeksu DJIA prezentuje tabela 5.2.

Tabela 5.2. Dynamika ryzyka względnego indeksu DJIA

\begin{tabular}{|l|c|c|c|c|c|c|c|}
\hline \multicolumn{1}{|c|}{ Horyzont inwestycyjny (lata) } & $\mathbf{1}$ & $\mathbf{5}$ & $\mathbf{1 0}$ & $\mathbf{1 5}$ & $\mathbf{2 0}$ & $\mathbf{2 5}$ & $\mathbf{3 0}$ \\
\hline Ryzyko względne indeksu DJIA & 3,77 & 2,54 & 2,16 & 1,92 & 1,81 & 1,56 & 1,11 \\
\hline Zmiana (\%) & & 32,45 & 42,58 & 48,98 & 51,90 & 58,65 & 70,5 \\
\hline
\end{tabular}

Źródło: opracowanie własne na podstawie: Global Financial Data.

Większa dynamika redukcji ryzyka względnego realnych stóp zwrotu benchmarku rynku amerykańskiego charakteryzuje krótkie horyzonty inwestycyjne. Dla horyzontów o długości 5-20 lat dynamika redukcji ryzyka względnego 
indeksu DJIA maleje. Impuls wzrostowy analizowanego parametru pojawia się na przestrzeni horyzontów o długościach 20-30 lat.

\subsection{Rynek brytyjski}

Pomimo że Wielka Brytania była jednym z trzech państw decydujących o rozstrzygnięciu II wojny światowej, gospodarczo wyszła z niej mocno osłabiona. Odbudowa gospodarki była możliwa dzięki pomocy Stanów Zjednoczonych. W latach 1945-1951 wprowadzono program nacjonalizacyjny. Ukierunkowana na kolonie gospodarka brytyjska nie była gotowa do pełnego wykorzystania proeksportowej koniunktury na surowce dla przemysłu zbrojeniowego Stanów Zjednoczonych w okresie wojny koreańskiej. Wybuch wojny koreańskiej dał impuls wzrostowy, przejściowo zakłócony w 1952 roku (PKB - 0,2\%, a inflacja 9,6\%). Porażka w konflikcie sueskim w 1956 roku spowodowała szybki rozpad imperium kolonialnego. Konserwatywna struktura gospodarki oraz mniejsze, w porównaniu z innymi krajami, nakłady na R\&D doprowadziły w 1959 roku do utraty pozycji europejskiego lidera pod względem PKB na rzecz Republiki Federalnej Niemiec. Efektem programu budowania „społeczeństwa dobrobytu” oraz w 1964 roku kolejnej nacjonalizacji niektórych gałęzi przemysłu była kilkunastoprocentowa dewaluacja funta w 1967 roku, co ożywiło eksport, ale również pobudziło inflację osiagającą w 1971 roku wartość 9,4\%. Głównym stymulatorem gospodarki brytyjskiej był, zgodny z zasadami keynesizmu, interwencjonizm państwowy. Wynikiem zwiększania nakładów na badania naukowe i wdrożeniowe od połowy lat 60 . XX wieku była malejąca luka technologiczna między Stanami Zjednoczonymi a Wielką Brytanią, jednak ubocznym skutkiem był wzrost inflacji, której apogeum (24\%) przypadło na 1975 rok. Eksploatacja własnych zasobów ropy naftowej spowodowała samowystarczalność zapotrzebowania na ropę, co w 1976 roku poskutkowało spadkiem inflacji (8\%), po czym przez kolejne trzy lata poziom inflacji ustalił się na poziomie kilkunastu procent. W 1979 roku rządy objęli konserwatyści, wprowadzając neoliberalizm monetarny (thatcheryzm), mający na celu restrukturyzację przemysłu, ustabilizowanie inflacji, wzmocnienie waluty. Nadejście drugiego kryzysu energetycznego udaremniło reformowanie gospodarki, wywołując w latach 1980-1981 największe spośród krajów rozwiniętych załamanie gospodarcze (PKB -2\%). Konsekwencją wprowadzanych reform był 3,5\% wzrost PKB oraz inflacja do 5\% w 1982 roku. W 1983 roku nastąpił znaczny wzrost obrotów międzynarodowych, a w 1986 roku cena ropy wróciła do poziomu przed kryzysem. W latach 1974-1990 gospodarka brytyjska rozwijała się w tempie 1,9\%. W dekadzie lat 90. XX wieku Anglia rozwijała się stabilnie, jednak w pierwszej dekadzie XXI wieku rozwój został 
zakłócony kryzysem subprime (w 2008 roku). Rynkową interpretację opisanych procesów ekonomicznych prezentuje rysunek 5.3.

Rysunek 5.3. Wartości indeksu FTSE i inflacji Wielkiej Brytanii (1950-2012)

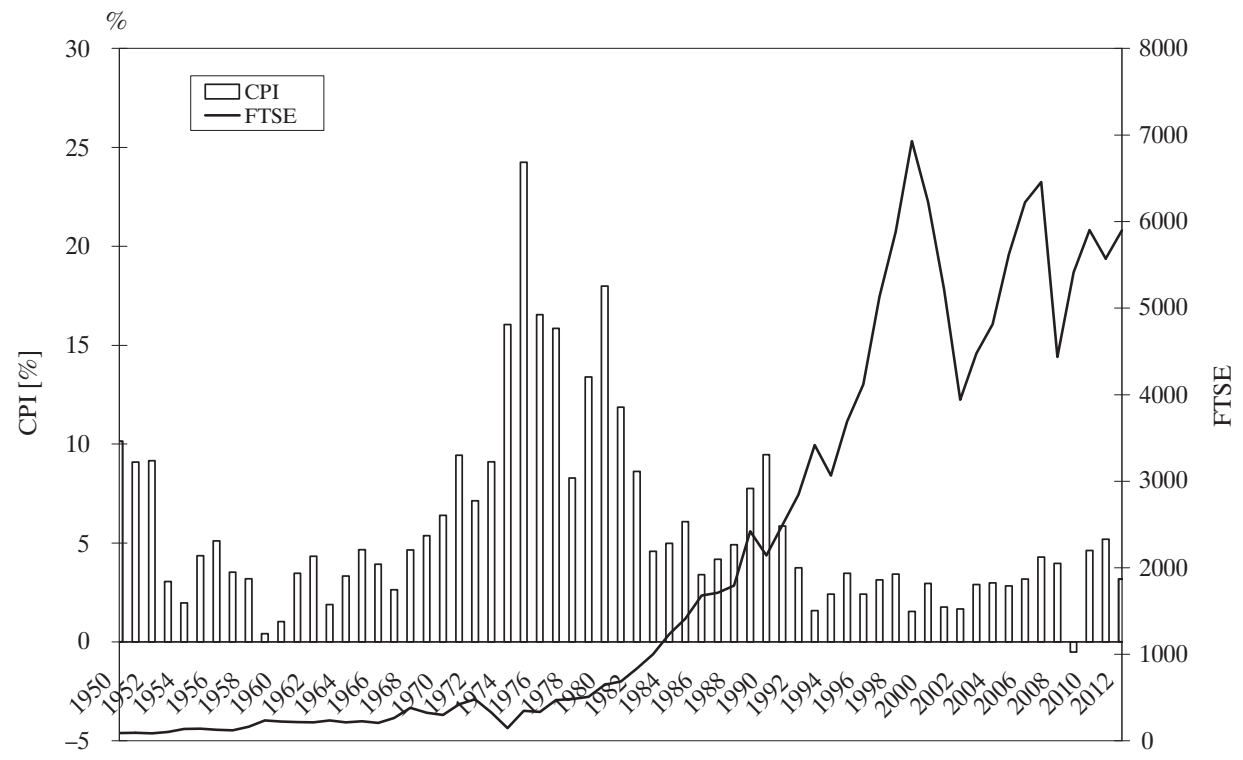

Źródło: opracowanie własne na podstawie: Global Financial Data.

W latach 1950-1973 londyński rynek akcji znajdował się w umiarkowanym trendzie wzrostowym; rosnąca amplituda naprzemiennych fluktuacji benchmarku LSE wskazuje, że w omawianym okresie rozwój gospodarki brytyjskiej nie dokonywał się bez trudności. Zachowanie rynku giełdowego w latach 1950-1955 było adekwatne do dość stabilnego 3\% wzrostu PKB w tym okresie. Porażka w konflikcie sueskim (w 1956 roku) zainicjowała dziesięcioletni okres większych odchyleń indeksu od linii trendu. Na dewaluację funta (w 1967 roku), wywołującą sukcesywny wzrost inflacji, a następnie stagflację w wyniku pierwszego kryzysu energetycznego, londyńska giełda zareagowała jeszcze większą dynamiką głównego indeksu. Eksploatacja podmorskich złóż ropy, łagodząca skutki pierwszego kryzysu energetycznego, oraz tatcheryzm osłabiający skutki drugiego kryzysu energetycznego w dużej mierze przyczyniły się do nieliniowego wzrostowego trendu benchmarku giełdy londyńskiej w latach 1974-1989. W okresie 1990-2012 indeks FTSE charakteryzują duże amplitudy fluktuacji wokół silnego trendu wzrostowego; punkty zwrotne wyznaczają zjawiska globalne - kryzys MTM w 2000 roku oraz kryzys subprime (w 2006 roku). Charakterystyki rozkładów realnych stop zwrotu indeksu FTSE prezentuje tabela 5.3. 
Tabela 5.3. Charakterystyki rozkładów realnych stop zwrotu indeksu FTSE

\begin{tabular}{|c|c|c|c|c|c|c|c|}
\hline \multirow{2}{*}{$\begin{array}{l}\text { Horyzont } \\
\text { inwestycyjny } \\
\text { (lata) }\end{array}$} & \multicolumn{3}{|c|}{ Stopa zwrotu } & \multirow{2}{*}{$\begin{array}{c}\text { Odchylenie } \\
\text { standardowe } \\
(\%)\end{array}$} & \multirow[b]{2}{*}{ Kurtoza } & \multirow[b]{2}{*}{ Skośność } & \multirow[b]{2}{*}{$\begin{array}{c}\text { Liczba } \\
\text { obserwacji }\end{array}$} \\
\hline & $\begin{array}{c}\underset{(\%)}{\operatorname{minimum}} \\
\end{array}$ & $\begin{array}{c}\text { maksimum } \\
(\%)\end{array}$ & $\begin{array}{c}\text { wartość } \\
\text { oczekiwana } \\
(\%)\end{array}$ & & & & \\
\hline 1 & $-65,32$ & 89,06 & 3,56 & 19,02 & 1,260 & $-0,040$ & 745 \\
\hline 2 & $-52,03$ & 40,04 & 2,57 & 13,19 & 1,320 & $-0,462$ & 733 \\
\hline 3 & $-37,52$ & 30,37 & 2,34 & 10,43 & 0,948 & $-0,595$ & 721 \\
\hline 4 & $-25,41$ & 22,90 & 2,14 & 8,48 & 0,487 & $-0,571$ & 709 \\
\hline 5 & $-22,87$ & 23,70 & 2,03 & 7,50 & 0,400 & $-0,500$ & 697 \\
\hline 6 & $-22,24$ & 21,61 & 2,01 & 6,74 & 0,369 & $-0,536$ & 685 \\
\hline 7 & $-16,45$ & 16,70 & 2,02 & 6,16 & $-0,007$ & $-0,451$ & 673 \\
\hline 8 & $-13,91$ & 14,20 & 2,01 & 5,67 & $-0,221$ & $-0,476$ & 661 \\
\hline 9 & $-11,72$ & 11,60 & 2,00 & 5,34 & $-0,557$ & $-0,527$ & 649 \\
\hline 10 & $-10,64$ & 11,48 & 1,93 & 5,09 & $-0,891$ & $-0,453$ & 637 \\
\hline 11 & $-10,68$ & 12,23 & 1,85 & 4,82 & $-0,964$ & $-0,393$ & 625 \\
\hline 12 & $-9,22$ & 11,55 & 1,83 & 4,52 & $-1,030$ & $-0,313$ & 613 \\
\hline 13 & $-8,85$ & 11,90 & 1,86 & 4,29 & $-0,959$ & $-0,297$ & 601 \\
\hline 14 & $-8,68$ & 9,83 & 1,89 & 4,08 & $-0,921$ & $-0,282$ & 589 \\
\hline 15 & $-8,55$ & 10,53 & 1,90 & 3,93 & $-0,907$ & $-0,148$ & 577 \\
\hline 16 & $-6,48$ & 9,50 & 1,92 & 3,73 & $-0,906$ & $-0,052$ & 565 \\
\hline 17 & $-5,75$ & 9,29 & 1,92 & 3,54 & $-0,798$ & 0,069 & 553 \\
\hline 18 & $-4,28$ & 9,16 & 1,92 & 3,38 & $-0,772$ & 0,143 & 541 \\
\hline 19 & $-4,72$ & 9,12 & 1,88 & 3,27 & $-0,786$ & 0,189 & 529 \\
\hline 20 & $-4,65$ & 8,51 & 1,85 & 3,13 & $-0,826$ & 0,162 & 517 \\
\hline 21 & $-3,89$ & 8,26 & 1,82 & 2,95 & $-0,831$ & 0,235 & 505 \\
\hline 22 & $-3,44$ & 8,29 & 1,79 & 2,80 & $-0,863$ & 0,338 & 493 \\
\hline 23 & $-2,98$ & 8,60 & 1,73 & 2,65 & $-0,735$ & 0,503 & 481 \\
\hline 24 & $-2,92$ & 8,57 & 1,72 & 2,49 & $-0,621$ & 0,618 & 469 \\
\hline 25 & $-2,59$ & 8,98 & 1,77 & 2,29 & $-0,460$ & 0,634 & 457 \\
\hline 26 & $-1,80$ & 8,15 & 1,85 & 2,07 & $-0,510$ & 0,539 & 445 \\
\hline 27 & $-1,75$ & 7,14 & 1,91 & 1,86 & $-0,800$ & 0,347 & 433 \\
\hline 28 & $-1,07$ & 5,86 & 1,94 & 1,68 & $-1,061$ & 0,229 & 421 \\
\hline 29 & $-1,06$ & 5,94 & 1,95 & 1,59 & $-0,973$ & 0,294 & 409 \\
\hline 30 & $-1,01$ & 5,92 & 1,96 & 1,52 & $-0,807$ & 0,346 & 397 \\
\hline
\end{tabular}

Źródło: opracowanie własne na podstawie: Global Financial Data. 
Wartości oczekiwanych stóp zwrotu dla 30-letniego horyzontu są ponad 1,5-krotnie mniejsze od wartości oczekiwanych stóp zwrotu dla horyzontu jednorocznego. Relacje wartości odchylenia standardowego dla analogicznych horyzontów są ponad dwunastokrotne. Wartości ryzyka względnego realnych oczekiwanych stóp zwrotu indeksu FTSE w zależności od długości horyzontu inwestycyjnego ilustruje rysunek 5.4.

Rysunek 5.4. Wartości ryzyka względnego indeksu FTSE

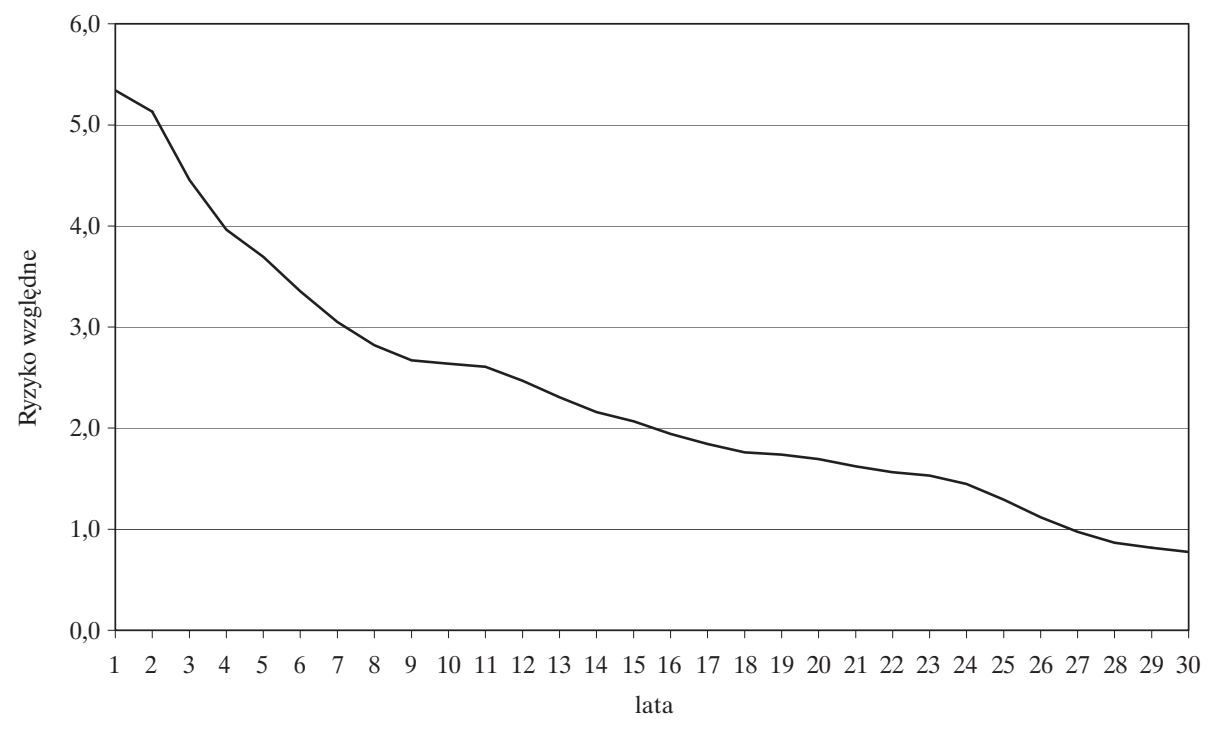

Źródło: opracowanie własne na podstawie: Global Financial Data.

Dynamikę ryzyka względnego realnych stóp zwrotu indeksu FTSE prezentuje tabela 5.4.

Tabela 5.4. Dynamika ryzyka względnego indeksu FTSE

\begin{tabular}{|l|c|c|c|c|c|c|c|}
\hline \multicolumn{1}{|c|}{ Horyzont inwestycyjny (lata) } & $\mathbf{1}$ & $\mathbf{5}$ & $\mathbf{1 0}$ & $\mathbf{1 5}$ & $\mathbf{2 0}$ & $\mathbf{2 5}$ & \multicolumn{1}{c|}{$\mathbf{3 0}$} \\
\hline Ryzyko względne indeksu FTSE & 5,34 & 3,69 & 2,64 & 2,07 & 1,69 & 1,29 & 0,78 \\
\hline Zmiana (\%) & & 30,91 & 50,58 & 61,36 & 68,31 & 75,82 & 85,49 \\
\hline
\end{tabular}

Źródło: opracowanie własne na podstawie: Global Financial Data.

Duża dynamika redukcji ryzyka względnego realnych stóp zwrotu benchmarku rynku brytyjskiego charakteryzuje horyzonty inwestycyjne 1-10 lat. Dla horyzontów o długości 10-25 lat dynamika redukcji ryzyka względnego indeksu 
FTSE maleje. Impuls wzrostowy analizowanego parametru pojawia się w horyzontach 25-30 lat.

\subsection{Rynek niemiecki}

Zniszczenia wojenne oraz reparacje wojenne znacznie osłabiły potencjał przemysłowy Niemiec. Pomoc Sranów Zjednoczonych i Anglii w odbudowie, eksport surowców dla przemysłu zbrojeniowego do USA w czasie boomu koreańskiego, brak obciążeń wydatkami zbrojeniowymi były silnymi impulsami „niemieckiego cudu gospodarczego”. W 1959 roku Niemcy stały się liderem pod względem PKB. W latach 60. XX wieku znaczącym wsparciem dla Niemiec były kredyty USA, a siłę napędową stanowiły nakłady na rozwój postępu naukowo-technicznego. W latach 1950-1973 produkcja przemysłowa RFN wzrosła prawie 5-krotnie, a utrzymująca się do 1970 roku podwartościowość marki dynamizowała handel zagraniczny (eksport wzrósł ponad trzydziestokrotnie), dając 5\% średnioroczne tempo wzrostu PKB przy jednoczesnym wzroście inflacji. Pierwszy kryzys energetyczny spowodował wzrost inflacji (7\% w 1974 roku) i załamanie koniunktury. Oparta w dużej mierze na węglu gospodarka niemiecka z kryzysu wyszła stosunkowo szybko, osiągając w 1976 roku 14,3 mld USD nadwyżkę w bilansie płatniczym. Drugi kryzys energetyczny nie pozwolił kontynuować łagodnego spadku inflacji, która w 1981 roku osiągnęła $6,3 \%$. Początek lat 80 . XX wieku to czas słabnięcia marki i redukcji kapitałów zagranicznych. Ograniczenie wydatków budżetowych, wysoki poziom eksportu i inwestycji spowodowały w okresie 1974-1990 2,3\% wzrost PKB. Przemiany w Europie Środkowo-Wschodniej po 1990 roku dały nowy impuls rozwoju gospodarczego przy kontrolowanym poziomie inflacji. Pomimo znacznych wydatków budżetowych z tytułu zjednoczenia Niemiec gospodarka niemiecka rozwijała się stabilnie. Kryzys subprime osłabił gospodarkę niemiecką. Rynkową interpretację przemian gospodarczych w Niemczech prezentuje rysunek 5.5. 
Rysunek 5.5. Wartości indeksu DAX i inflacji Niemiec (1950-2012)

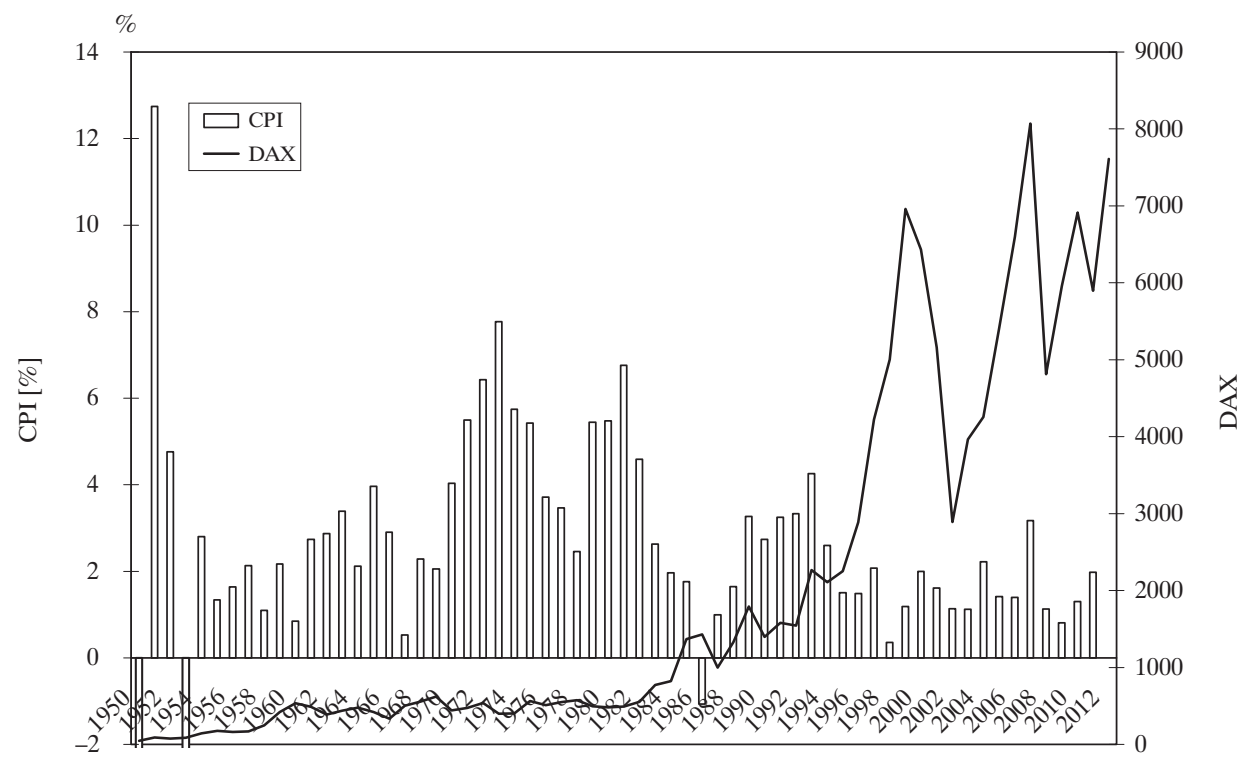

Źródło: opracowanie własne na podstawie: Global Financial Data.

Dobra koniunktura niemieckiej giełdy w latach 1950-1958 reprezentowana relatywnie małymi fluktuacjami benchmarku wokół trendu wzrostowego koresponduje $\mathrm{z}$ dobrą kondycją niemieckiej gospodarki w tym okresie. Pomimo kryzysów energetycznych kondycja niemieckiej gospodarki była dobra, na co wskazuje utrzymujący się przez dwie dekady 1959-1982 wzrostowy trend giełdowy. Silnie wzrostowa koniunktura giełdy niemieckiej w okresie 1983-1995 reprezentuje kondycję gospodarki przełomu lat 80. i 90. XX wieku. Znaczne fluktuacje indeksu DAX wokól trendu są adekwatne do obciążeń ekonomicznych, związanych ze zjednoczeniem Niemiec. Trend wzrostowy w okresie 1996-2012 świadczy o dobrej kondycji gospodarki niemieckiej w pierwszej dekadzie XXI wieku. Wpływ otoczenia zewnętrznego na gospodarkę niemiecką manifestuje się podobnie jak u pozostałych dużymi fluktuacjami benchmarku. Charakterystyki rozkładów realnych stop zwrotu indeksu DAX prezentuje tabela 5.5. 
Tabela 5.5. Charakterystyki rozkładów realnych stop zwrotu indeksu DAX

\begin{tabular}{|c|c|c|c|c|c|c|c|}
\hline \multirow[b]{2}{*}{$\begin{array}{c}\text { Horyzont } \\
\text { inwestycyjny } \\
\text { (lata) }\end{array}$} & \multicolumn{3}{|c|}{ Stopa zwrotu } & \multirow[b]{2}{*}{$\begin{array}{c}\text { Odchylenie } \\
\text { standardowe } \\
(\%)\end{array}$} & \multirow[b]{2}{*}{ Kurtoza } & \multirow[b]{2}{*}{ Skośność } & \multirow[b]{2}{*}{$\begin{array}{c}\text { Ilość } \\
\text { obserwacji }\end{array}$} \\
\hline & $\underset{(\%)}{\operatorname{minimum}}$ & $\begin{array}{c}\text { maksimum } \\
(\%)\end{array}$ & $\begin{array}{c}\text { wartość } \\
\text { oczekiwana } \\
(\%)\end{array}$ & & & & \\
\hline 1 & $-52,60$ & 98,18 & 7,09 & 25,03 & 0,193 & 0,538 & 745 \\
\hline 2 & $-36,60$ & 70,75 & 5,67 & 18,50 & 0,511 & 0,652 & 733 \\
\hline 3 & $-32,71$ & 54,24 & 4,88 & 14,30 & 0,380 & 0,672 & 721 \\
\hline 4 & $-18,34$ & 39,51 & 4,52 & 11,87 & $-0,305$ & 0,622 & 709 \\
\hline 5 & $-16,05$ & 28,93 & 4,34 & 10,38 & $-0,766$ & 0,473 & 697 \\
\hline 6 & $-12,87$ & 30,95 & 4,17 & 9,04 & $-0,296$ & 0,619 & 685 \\
\hline 7 & $-10,09$ & 33,14 & 4,04 & 8,21 & 0,594 & 0,931 & 673 \\
\hline 8 & $-8,61$ & 27,93 & 3,93 & 7,53 & 0,672 & 0,993 & 661 \\
\hline 9 & $-10,66$ & 25,37 & 3,80 & 7,10 & 0,580 & 0,869 & 649 \\
\hline 10 & $-6,76$ & 26,18 & 3,56 & 6,64 & 1,011 & 0,886 & 637 \\
\hline 11 & $-6,17$ & 23,70 & 3,33 & 6,06 & 0,601 & 0,699 & 625 \\
\hline 12 & $-6,02$ & 19,59 & 3,18 & 5,42 & $-0,287$ & 0,348 & 613 \\
\hline 13 & $-6,74$ & 15,90 & 3,15 & 4,90 & $-0,381$ & 0,109 & 601 \\
\hline 14 & $-7,35$ & 15,87 & 3,12 & 4,54 & $-0,276$ & 0,057 & 589 \\
\hline 15 & $-5,90$ & 13,78 & 3,08 & 4,26 & $-0,566$ & 0,055 & 577 \\
\hline 16 & $-5,46$ & 11,94 & 3,04 & 4,02 & $-0,596$ & 0,036 & 565 \\
\hline 17 & $-5,06$ & 10,77 & 3,01 & 3,85 & $-0,497$ & 0,062 & 553 \\
\hline 18 & $-4,72$ & 11,36 & 2,97 & 3,73 & $-0,273$ & 0,138 & 541 \\
\hline 19 & $-4,80$ & 11,14 & 2,91 & 3,53 & $-0,201$ & 0,058 & 529 \\
\hline 20 & $-4,88$ & 10,54 & 2,84 & 3,22 & $-0,032$ & $-0,121$ & 517 \\
\hline 21 & $-5,07$ & 9,38 & 2,79 & 2,90 & 0,269 & $-0,298$ & 505 \\
\hline 22 & $-5,02$ & 8,86 & 2,77 & 2,72 & 0,014 & $-0,274$ & 493 \\
\hline 23 & $-3,57$ & 8,42 & 2,77 & 2,55 & $-0,508$ & $-0,205$ & 481 \\
\hline 24 & $-3,08$ & 6,94 & 2,77 & 2,31 & $-0,814$ & $-0,064$ & 469 \\
\hline 25 & $-1,57$ & 7,24 & 2,79 & 2,13 & $-0,997$ & 0,261 & 457 \\
\hline 26 & $-1,37$ & 6,91 & 2,81 & 1,95 & $-0,888$ & 0,286 & 445 \\
\hline 27 & $-1,81$ & 6,27 & 2,86 & 1,78 & $-0,631$ & $-0,174$ & 433 \\
\hline 28 & $-1,49$ & 5,88 & 2,88 & 1,63 & $-0,487$ & $-0,390$ & 421 \\
\hline 29 & $-0,47$ & 5,52 & 2,88 & 1,47 & $-0,717$ & $-0,441$ & 409 \\
\hline 30 & $-1,00$ & 5,27 & 2,87 & 1,41 & $-0,601$ & $-0,606$ & 397 \\
\hline
\end{tabular}

Źródło: opracowanie własne na podstawie Global Financial Data. 
Wartości oczekiwanych stóp zwrotu dla 30-letniego horyzontu są ponad 2-krotnie mniejsze od wartości oczekiwanych stóp zwrotu dla horyzontu jednorocznego. Relacje wartości odchylenia standardowego dla analogicznych horyzontów są prawie siedemnastokrotne. Wartości ryzyka względnego realnych oczekiwanych stóp zwrotu indeksu DAX w zależności od długości horyzontu inwestycyjnego ilustruje rysunek 5.6.

Rysunek 5.6. Wartości ryzyka względnego indeksu DAX

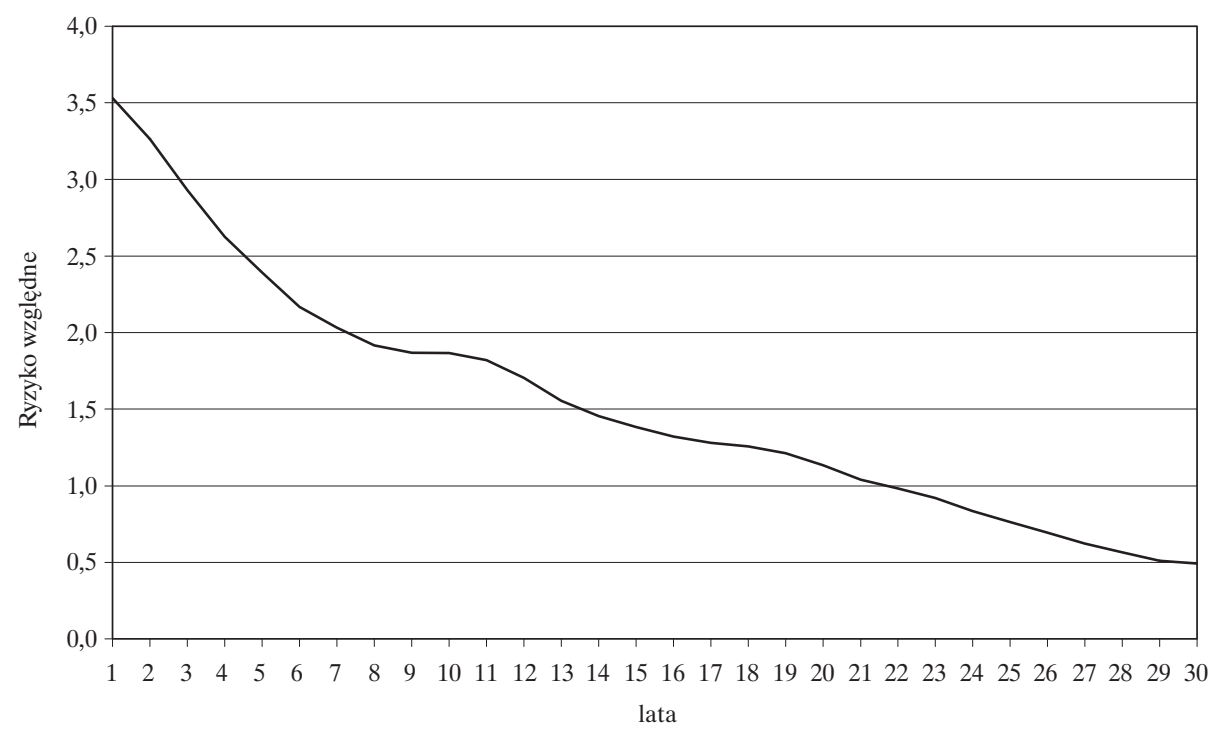

Źródło: opracowanie własne na podstawie: Global Financial Data.

Dynamikę ryzyka względnego realnych stóp zwrotu indeksu DAX prezentuje tabela 5.6.

Tabela 5.6. Dynamika ryzyka względnego indeksu DAX

\begin{tabular}{|l|c|c|c|c|c|c|c|}
\hline \multicolumn{1}{|c|}{ Horyzont inwestycyjny [lata] } & $\mathbf{1}$ & $\mathbf{5}$ & $\mathbf{1 0}$ & $\mathbf{1 5}$ & $\mathbf{2 0}$ & $\mathbf{2 5}$ & $\mathbf{3 0}$ \\
\hline Ryzyko względne indeksu DAX & 3,53 & 2,39 & 1,87 & 1,38 & 1,13 & 0,76 & 0,49 \\
\hline Zmiana (\%) & & 32,34 & 47,16 & 60,84 & 67,85 & 78,33 & 86,14 \\
\hline
\end{tabular}

Źródło: opracowanie własne na podstawie: Global Financial Data.

Większa dynamika redukcji ryzyka względnego realnych stóp zwrotu benchmarku rynku niemieckiego charakteryzuje horyzonty inwestycyjne 1-15 lat. Dla horyzontów o długości 15-20 lat dynamika redukcji ryzyka względnego indeksu 
DAX jest bardziej stabilna. Impuls wzrostowy analizowanego parametru pojawia się w horyzontach 20-25 lat. Dynamika redukcji ryzyka względnego realnej stopy zwrotu indeksów DAX oraz FTSE na przestrzeni 30-letniego horyzontu inwestycyjnego jest porównywalna.

\subsection{Rynek francuski}

W odbudowie francuskiej gospodarki istotną rolę odegrał Plan Marshalla oraz pomoc Stanów Zjednoczonych. Fundamentem polityki gospodarczej Francji było centralne planowanie oraz nacjonalizacja sektorów: energetycznego, górnictwa węglowego, transportu lotniczego, znacznej części banków. Militarne zaangażowanie w Indochinach nie pozwoliło na pełne wykorzystanie przez Francję proeksportowej koniunktury boomu koreańskiego - w latach 1952-1953 zanotowano spadek tempa rozwoju. Zaangażowanie militarne w Indochinach oraz w Algierii poskutkowało brakiem odporności Francji na ogólnoświatowy spadek koniunktury w latach 1958-1959. Realizacja programu Wielkiej Francji, opartego na mocnej gospodarce oraz dewaluacja i wymiana franka, zwiększyły konkurencyjność eksportu. Zasilenie kapitałowe i technologiczne z USA spowodowały w latach 1960-1970 średni wzrost PKB o 5,7\%. Recesja gospodarcza spowodowana pierwszym kryzysem energetycznym miała mniejsze rozmiary niż w innych krajach - w 1980 roku. Francja pod względem wielkości dochodu narodowego ustępowała tylko RFN. Koniec drugiego kryzysu energetycznego zbiegł się ze zmianami politycznymi, rządy prawicowo-liberalne zastąpione zostały w 1981 roku - lewicowymi. Konsekwencją osłabienia kryzysami naftowymi oraz przeprowadzonej za wysokimi odszkodowaniami nacjonalizacji było pogorszenie konkurencyjności gospodarki francuskiej, co z kolei wywołało kilkunastoprocentową inflację. W latach 1981-1983 ze względu na trudności handlowe nastąpily dwie dewaluacje franka. W 1986 roku, po objęciu rządów przez prawicę, dokonano reprywatyzacji wobec znacjonalizowanych banków i przedsiębiorstw. W latach 1974-1990 Francja rozwijała się dość dobrze, szybciej niż Anglia i podobnie jak Niemcy. Przemiany w Europie Środkowo-Wschodniej nie były dla gospodarki francuskiej, jak dla gospodarki niemieckiej, silnym impulsem. W pierwszej dekadzie XXI wieku gospodarka francuska rozwijała się w miarę stabilnie. Kryzys subprime wywołał w porównaniu z Anglią i Stanami Zjednoczonymi relatywnie mniejsze osłabienie. Rynkową interpretację zjawisk zachodzących w gospodarce francuskiej prezentuje rysunek 5.7. 
Rysunek 5.7. Wartości indeksu CAC 40 i inflacji Francji (1950-2012)

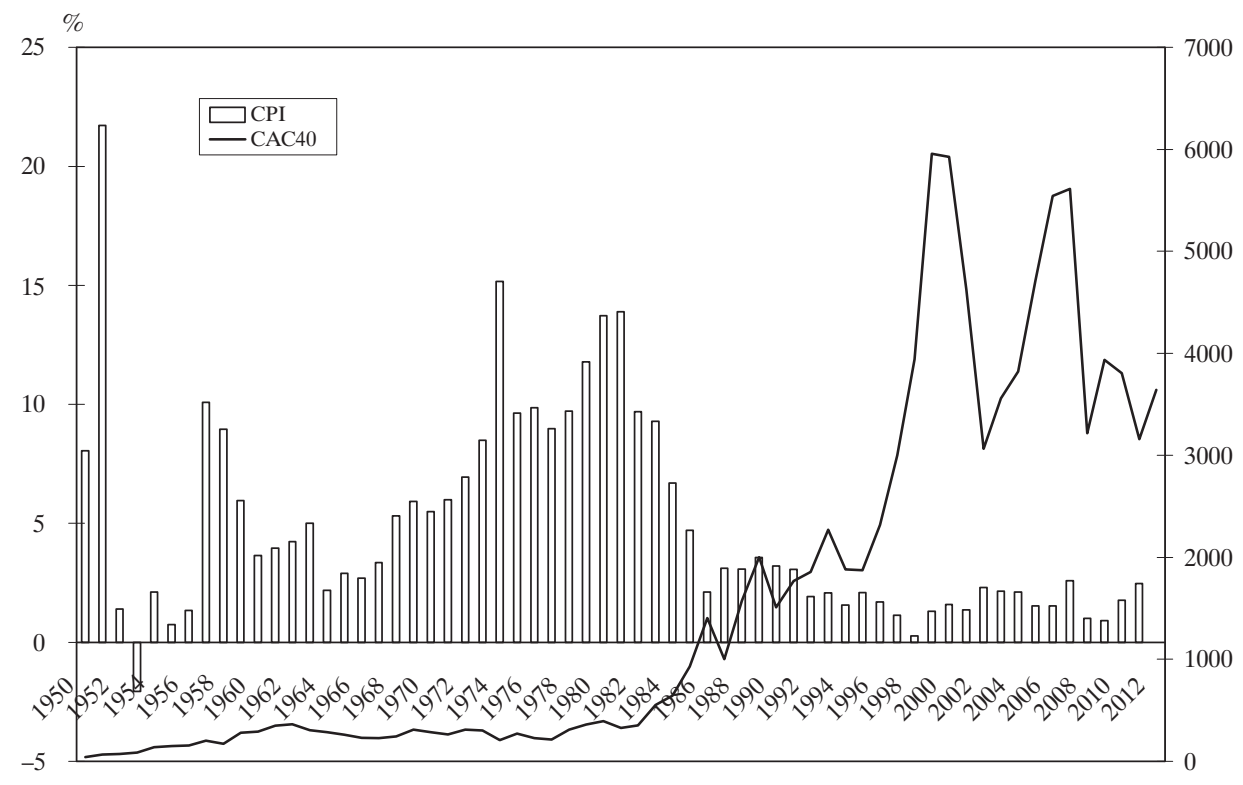

Źródło: opracowanie własne na podstawie: Global Financial Data.

Niezbyt duże amplitudy fluktuacji benchmarku francuskiego rynku akcji wokół umiarkowanie wzrostowego trendu w okresie 1950-1962 sugerują, że przegranie wojny w Indochinach (1945-1954) oraz w Algierii (1954-1962) nie wpłynęło na zachowanie tego rynku. Relatywnie większe odchylenie indeksu od linii trendu w 1958 roku sygnalizuje małą odporność francuskiej gospodarki na ogólnoświatowy spadek koniunktury w latach 1958-1959. Dewaluacja franka (w 1960 roku) pobudzająca eksport i postęp technologiczny zdynamizowały gospodarkę francuską lat 70 . XX wieku. Zarówno dobra kondycja gospodarki francuskiej, jak i lepsza od innych krajów kompensacja negatywnych skutków obu kryzysów energetycznych pozwoliły na utrzymanie korzystnej koniunktury giełdowej, ale o słabszym niż poprzednio trendzie wzrostowym i silniejszych fluktuacjach benchmarku. Dwie dewaluacje franka w latach 1981-1983 zainicjowały piętnastoletni okres silnego trendu wzrostowego indeksu CAC 40, którego znaczna dynamika była reakcją rynku na burzliwe przemiany polityczno-gospodarcze w Europie końca XX wieku. Rosnąca skala wzajemnych oddziaływań rynkowych w wyniku postępującego procesu globalizacji przejawiała się znaczną niestabilnością benchmarku giełdy paryskiej wokół trendu spadkowego w okresie 1997-2012. Charakterystyki rozkładów realnych stop zwrotu indeksu CAC 40 prezentuje tabela 5.7. 
Tabela 5.7. Charakterystyki rozkładów realnych stop zwrotu indeksu CAC 40

\begin{tabular}{|c|c|c|c|c|c|c|c|}
\hline \multirow[b]{2}{*}{$\begin{array}{c}\text { Horyzont } \\
\text { inwestycyjny } \\
\text { (lata) }\end{array}$} & \multicolumn{3}{|c|}{ Stopa zwrotu } & \multirow[b]{2}{*}{$\begin{array}{c}\text { Odchylenie } \\
\text { standardowe } \\
(\%)\end{array}$} & \multirow[b]{2}{*}{ Kurtoza } & \multirow[b]{2}{*}{ Skośność } & \multirow[b]{2}{*}{$\begin{array}{c}\text { Ilość } \\
\text { obserwacji }\end{array}$} \\
\hline & $\underset{(\%)}{\operatorname{minimum}}$ & $\begin{array}{c}\text { maksimum } \\
(\%)\end{array}$ & $\begin{array}{c}\text { wartość } \\
\text { oczekiwana } \\
(\%)\end{array}$ & & & & \\
\hline 1 & $-50,02$ & 81,60 & 4,80 & 22,67 & 0,106 & 0,286 & 745 \\
\hline 2 & $-34,50$ & 50,00 & 3,79 & 16,82 & $-0,415$ & 0,264 & 733 \\
\hline 3 & $-26,77$ & 39,63 & 3,37 & 14,03 & $-0,573$ & 0,361 & 721 \\
\hline 4 & $-24,15$ & 34,08 & 3,11 & 12,41 & $-0,386$ & 0,482 & 709 \\
\hline 5 & $-18,74$ & 27,45 & 2,90 & 10,75 & $-0,616$ & 0,393 & 697 \\
\hline 6 & $-15,22$ & 24,03 & 2,75 & 9,29 & $-0,870$ & 0,322 & 685 \\
\hline 7 & $-13,82$ & 22,14 & 2,65 & 8,45 & $-0,943$ & 0,265 & 673 \\
\hline 8 & $-13,40$ & 18,97 & 2,52 & 7,96 & $-1,070$ & 0,144 & 661 \\
\hline 9 & $-10,90$ & 17,53 & 2,45 & 7,69 & $-1,226$ & 0,086 & 649 \\
\hline 10 & $-9,69$ & 16,03 & 2,32 & 7,30 & $-1,380$ & 0,038 & 637 \\
\hline 11 & $-9,78$ & 15,23 & 2,22 & 6,90 & $-1,401$ & $-0,049$ & 625 \\
\hline 12 & $-9,97$ & 14,27 & 2,18 & 6,52 & $-1,294$ & $-0,124$ & 613 \\
\hline 13 & $-9,11$ & 13,51 & 2,16 & 6,02 & $-1,227$ & $-0,241$ & 601 \\
\hline 14 & $-9,72$ & 12,50 & 2,14 & 5,70 & $-1,064$ & $-0,286$ & 589 \\
\hline 15 & $-10,35$ & 13,28 & 2,13 & 5,55 & $-0,789$ & $-0,194$ & 577 \\
\hline 16 & $-9,26$ & 13,86 & 2,10 & 5,40 & $-0,602$ & $-0,081$ & 565 \\
\hline 17 & $-8,25$ & 14,55 & 2,05 & 5,26 & $-0,470$ & $-0,014$ & 553 \\
\hline 18 & $-7,44$ & 14,25 & 2,01 & 5,10 & $-0,479$ & 0,005 & 541 \\
\hline 19 & $-7,76$ & 13,65 & 1,99 & 4,95 & $-0,637$ & $-0,039$ & 529 \\
\hline 20 & $-7,67$ & 11,63 & 1,96 & 4,75 & $-0,783$ & $-0,121$ & 517 \\
\hline 21 & $-7,03$ & 10,71 & 1,93 & 4,56 & $-0,838$ & $-0,080$ & 505 \\
\hline 22 & $-6,17$ & 11,32 & 1,92 & 4,44 & $-0,892$ & 0,033 & 493 \\
\hline 23 & $-5,70$ & 11,01 & 1,91 & 4,23 & $-0,874$ & 0,184 & 481 \\
\hline 24 & $-5,45$ & 9,86 & 1,90 & 3,97 & $-0,894$ & 0,249 & 469 \\
\hline 25 & $-5,26$ & 9,10 & 1,91 & 3,71 & $-0,979$ & 0,234 & 457 \\
\hline 26 & $-4,34$ & 9,01 & 1,95 & 3,44 & $-1,094$ & 0,156 & 445 \\
\hline 27 & $-3,74$ & 7,39 & 2,00 & 3,18 & $-1,262$ & 0,069 & 433 \\
\hline 28 & $-3,38$ & 7,55 & 2,03 & 2,93 & $-1,257$ & 0,106 & 421 \\
\hline 29 & $-2,31$ & 7,70 & 2,03 & 2,69 & $-1,234$ & 0,278 & 409 \\
\hline 30 & $-1,73$ & 7,62 & 2,00 & 2,46 & $-1,166$ & 0,370 & 397 \\
\hline
\end{tabular}

Źródło: opracowanie własne na podstawie: Global Financial Data. 
Wartości oczekiwanych stóp zwrotu dla 30-letniego horyzontu są ponad 2-krotnie mniejsze od wartości oczekiwanych stóp zwrotu dla horyzontu jednorocznego. Relacje wartości odchylenia standardowego dla analogicznych horyzontów są ponad dziewięciokrotne. Wartości ryzyka względnego realnych oczekiwanych stóp zwrotu indeksu CAC $40 \mathrm{w}$ zależności od długości horyzontu inwestycyjnego ilustruje rysunek 5.8.

Rysunek 5.8. Wartości ryzyka względnego indeksu CAC 40

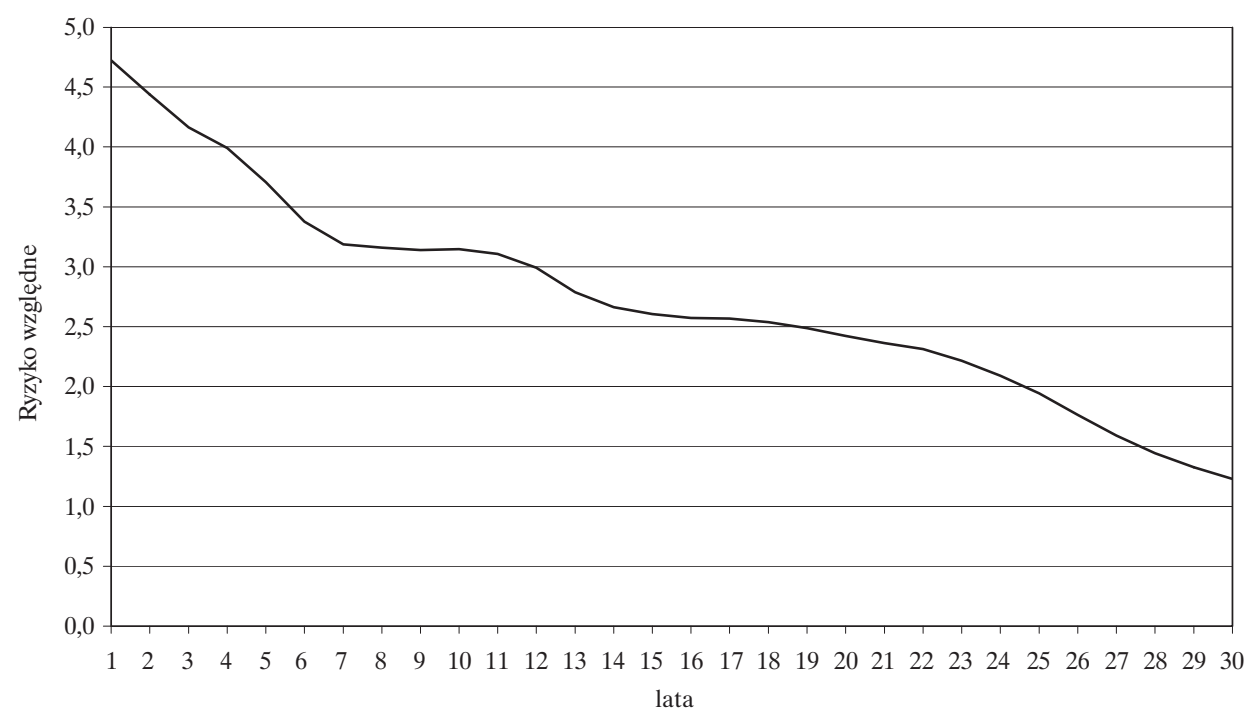

Źródło: opracowanie własne na podstawie: Global Financial Data.

Dynamikę ryzyka względnego realnych stóp zwrotu indeksu CAC 40 prezentuje tabela 5.8.

Tabela 5.8. Dynamika ryzyka względnego indeksu CAC 40

\begin{tabular}{|l|c|c|c|c|c|c|c|}
\hline \multicolumn{1}{|c|}{ Horyzont inwestycyjny (lata) } & $\mathbf{1}$ & $\mathbf{5}$ & $\mathbf{1 0}$ & $\mathbf{1 5}$ & $\mathbf{2 0}$ & $\mathbf{2 5}$ & $\mathbf{3 0}$ \\
\hline Ryzyko względne indeksu CAC 40 & 4,73 & 3,70 & 3,14 & 2,61 & 2,42 & 1,94 & 1,23 \\
\hline Zmiana (\%) & & 21,65 & 33,51 & 44,76 & 48,72 & 58,86 & 73,95 \\
\hline
\end{tabular}

Źródło: opracowanie własne na podstawie: Global Financial Data.

Benchmark rynku francuskiego charakteryzuje znacznie mniejsza dynamika redukcji ryzyka względnego realnych stóp zwrotu w porównaniu z wcześniej analizowanymi indeksami. Dynamika analizowanego parametru jest stabilna 
dla horyzontów inwestycyjnych 5-15 lat. Dla horyzontów o długości 15-25 lat dynamika redukcji ryzyka względnego indeksu CAC 40 stabilizuje się na niższym poziomie. Impuls wzrostowy analizowanego parametru pojawia się w horyzontach 25-30 lat. Dynamika redukcji ryzyka względnego realnej stopy zwrotu indeksów CAC 40 oraz DJIA wykazuje podobieństwo.

\subsection{Rynek japoński}

Skutkiem utraty kolonii oraz znacznych zniszczeń podczas II wojny światowej była depresja gospodarcza w okresie powojennym. Zwycięstwo komunistów w Chinach w 1949 roku zmusiło Stany Zjednoczone do zmiany polityki wobec Japonii. Wdrożenie drastycznych reform oraz 2 mld USD kredytu od Stanów Zjednoczonych nie przywróciły przedwojennego poziomu produkcji przemysłowej. Silnym impulsem była wojna koreańska $-\mathrm{z}$ tytułu obsługi wojskowej i aprowizacyjnej Japonia otrzymała od Stanów Zjednoczonych 1,4 mld USD, zdynamizował się eksport. Kolejny silny impuls wzrostowy pojawił się na skutek wojny wietnamskiej (1964-1973). W wyniku stabilizacji politycznej i interwencjonizmu państwowego w latach 1950-1973 gospodarka japońska, nazywana ,cudem gospodarczym”, rozwijała się średniorocznie w tempie: PKB - 9,2\%; produkcja przemysłowa $-14,6 \%$; inflacja $-5,2 \%$. Efektem znacznego uzależnienia gospodarki od importu był spadek tempa wzrostu PKB oraz wzrost inflacji (24\%) na skutek pierwszego kryzysu energetycznego. W wyniku reakcji, jaką było znaczne ograniczenie wydatków budżetowych, inflacja obniżyła się w 1976 roku do poziomu 10\%, a w 1978 roku wyniosła 4,2\%, co przyczyniło się do aprecjacji jena. Mimo że drugi kryzys energetyczny był mniej dotkliwy dla gospodarki japońskiej, jen uległ deprecjacji. W latach 80. XX wieku nastąpiło ograniczenie importu oraz ożywienie eksportu - szczególnie eksportu kapitału, dzięki czemu Japonia była liderem inwestycji zagranicznych, co przyczyniło się do aprecjacji i internacjonalizacji jena. Dynamicznie rosnący popyt wewnętrzny i niska inflacja w drugiej połowie lat $80 \mathrm{XX}$ wieku wykreowały koniunkturę sprzyjającą inwestycjom z dźwignią finansową, nazywaną „bańką mydlaną”. Gospodarka japońska w latach 1974-1990 rozwijała się najszybciej spośród rozwiniętych krajów kapitalistycznych, osiągając średnioroczne tempo: PKB, 3,9\%; produkcji przemysłowej 3,5\%; inflacji 5,2\%. W obawie przed skutkami „pęknięcia bańki mydlanej” bank Japonii od 1989 roku zaczął podnosić stopy procentowe, co wywołało pęknięcie bańki i aprecjację jena. Nastąpiło pierwsze w historii powojennej spowolnienie, a tempo wzrostu PKB Japonii było niższe od tempa wzrostu pozostałych wysoko rozwiniętych państw, powodując w latach 1991-1993 recesję Heisei. Wzrost inwestycji i konsumpcji w latach 1995-1996 wywołały ożywienie, ale natychmiastowe podniesienie stawek podatkowych spowodowało powrót recesji. Zła polityka kredytowa lat 80 . 
XX wieku, negatywne zjawiska w gospodarcze oraz kryzys azjatycki 1997-1999 wywołały kryzys w sektorze bankowym. Reakcją było podniesienie wymogów zdolności kredytowej, co skutkowało w latach 2000-2002 kolejną recesją gospodarki realnej. Lata 90. XX wieku, nazywane „straconą dekadą” Japonii, będą konsekwencją długotrwałej deflacji. Zapoczątkowany w ostatniej dekadzie XX wieku kryzys utrzymał się w pierwszej dekadzie XXI wieku. Rynkową interpretację etapów rozwoju gospodarki japońskiej prezentuje rysunek 5.9.

Rysunek 5.9. Wartości indeksu NIKKEI 225 i inflacji Japonii (1950-2012)

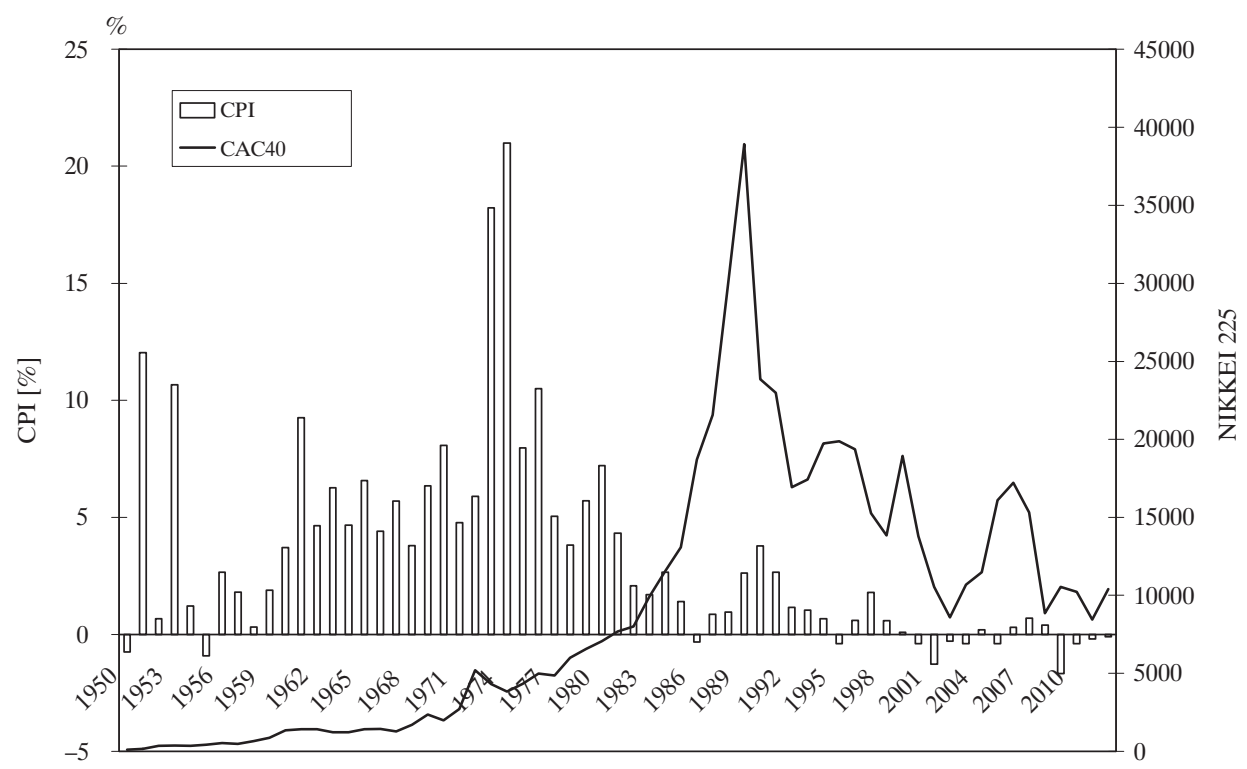

Źródło: opracowanie własne na podstawie: Global Financial Data.

Japoński „cud gospodarczy” na tokijskiej giełdzie manifestował się silnym trendem wzrostowym w okresie 1950-1958, następnie nieznacznie osłabł w okresie 1959-1968 i zdynamizował się w końcowej fazie 1970-1972. Wywołane kryzysami energetycznymi negatywne skutki gospodarcze nie zmieniły wzrostowej koniunktury giełdy tokijskiej w okresie 1969-1982. Symptomem giełdowym eksplozji japońskiego eksportu w latach 80 . XX wieku oraz „polityki budzenia konsumpcji krajowej” był wykładniczy trend wzrostowy benchmarku giełdy tokijskiej w latach 1983-1989. Następstwem „gospodarki bańki mydlanej” był kryzys początku lat 90 . XX wieku rozpoczynający spadkową koniunkturę giełdową kontynuowaną w wyniku kryzysów azjatyckiego i subprime. Charakterystyki rozkładów realnych stop zwrotu indeksu NIKKEI 225 prezentuje tabela 5.9. 
Tabela 5.9. Charakterystyki rozkładów realnych stop zwrotu indeksu NIKKEI 225

\begin{tabular}{|c|c|c|c|c|c|c|c|}
\hline \multirow{2}{*}{$\begin{array}{l}\text { Horyzont } \\
\text { inwestycyjny } \\
\text { (lata) }\end{array}$} & \multicolumn{3}{|c|}{ Stopa zwrotu } & \multirow{2}{*}{$\begin{array}{c}\text { Odchylenie } \\
\text { standardowe } \\
(\%)\end{array}$} & \multirow[b]{2}{*}{ Kurtoza } & \multirow[b]{2}{*}{ Skośność } & \multirow[b]{2}{*}{$\begin{array}{c}\text { Ilośćc } \\
\text { obserwacji }\end{array}$} \\
\hline & $\begin{array}{c}\underset{(\%)}{\operatorname{minimum}} \\
\end{array}$ & $\begin{array}{c}\text { maximum } \\
(\%)\end{array}$ & $\begin{array}{c}\text { wartość } \\
\text { oczekiwana } \\
(\%)\end{array}$ & & & & \\
\hline 1 & $-49,60$ & 136,81 & 6,84 & 25,05 & 2,070 & 0,894 & 745 \\
\hline 2 & $-34,72$ & 88,85 & 5,61 & 18,65 & 0,840 & 0,658 & 733 \\
\hline 3 & $-26,31$ & 63,67 & 4,82 & 14,91 & 0,060 & 0,473 & 721 \\
\hline 4 & $-20,24$ & 35,00 & 4,22 & 12,62 & $-0,906$ & 0,324 & 709 \\
\hline 5 & $-15,82$ & 28,78 & 4,05 & 11,35 & $-0,856$ & 0,411 & 697 \\
\hline 6 & $-14,14$ & 28,05 & 4,00 & 10,01 & $-0,600$ & 0,509 & 685 \\
\hline 7 & $-13,82$ & 25,22 & 3,92 & 8,99 & $-0,633$ & 0,491 & 673 \\
\hline 8 & $-12,28$ & 23,99 & 3,80 & 8,36 & $-0,663$ & 0,467 & 661 \\
\hline 9 & $-12,01$ & 24,96 & 3,70 & 7,96 & $-0,169$ & 0,535 & 649 \\
\hline 10 & $-9,49$ & 26,82 & 3,52 & 7,47 & 0,316 & 0,632 & 637 \\
\hline 11 & $-9,95$ & 26,47 & 3,34 & 7,02 & 0,401 & 0,547 & 625 \\
\hline 12 & $-11,07$ & 22,11 & 3,17 & 6,48 & 0,068 & 0,218 & 613 \\
\hline 13 & $-11,66$ & 19,50 & 3,10 & 6,02 & $-0,091$ & $-0,068$ & 601 \\
\hline 14 & $-10,59$ & 16,69 & 3,07 & 5,66 & $-0,400$ & $-0,282$ & 589 \\
\hline 15 & $-8,83$ & 14,47 & 3,06 & 5,39 & $-0,565$ & $-0,357$ & 577 \\
\hline 16 & $-7,36$ & 14,37 & 3,09 & 5,10 & $-0,723$ & $-0,368$ & 565 \\
\hline 17 & $-6,44$ & 13,15 & 3,13 & 4,83 & $-0,883$ & $-0,328$ & 553 \\
\hline 18 & $-7,00$ & 12,45 & 3,17 & 4,74 & $-0,789$ & $-0,228$ & 541 \\
\hline 19 & $-8,24$ & 12,95 & 3,23 & 4,63 & $-0,562$ & $-0,250$ & 529 \\
\hline 20 & $-7,55$ & 12,69 & 3,27 & 4,49 & $-0,403$ & $-0,320$ & 517 \\
\hline 21 & $-6,69$ & 12,91 & 3,30 & 4,41 & $-0,097$ & $-0,268$ & 505 \\
\hline 22 & $-7,06$ & 14,22 & 3,37 & 4,27 & 0,269 & $-0,190$ & 493 \\
\hline 23 & $-6,24$ & 14,05 & 3,41 & 3,92 & 0,418 & $-0,237$ & 481 \\
\hline 24 & $-5,25$ & 11,81 & 3,46 & 3,46 & 0,163 & $-0,333$ & 469 \\
\hline 25 & $-4,70$ & 10,44 & 3,54 & 3,12 & $-0,102$ & $-0,326$ & 457 \\
\hline 26 & $-3,33$ & 10,03 & 3,62 & 2,83 & $-0,494$ & $-0,233$ & 445 \\
\hline 27 & $-1,97$ & 9,50 & 3,67 & 2,64 & $-0,798$ & $-0,165$ & 433 \\
\hline 28 & $-1,31$ & 9,23 & 3,70 & 2,62 & $-0,938$ & $-0,124$ & 421 \\
\hline 29 & $-1,15$ & 9,37 & 3,73 & 2,68 & $-0,985$ & $-0,047$ & 409 \\
\hline 30 & $-1,78$ & 9,12 & 3,73 & 2,71 & $-0,991$ & 0,039 & 397 \\
\hline
\end{tabular}

Źródło: opracowanie własne na podstawie Global Financial Data. 
Wartości oczekiwanych stóp zwrotu dla 30-letniego horyzontu są 1,8-krotnie mniejsze od wartości oczekiwanych stóp zwrotu dla horyzontu jednorocznego. Relacje wartości odchylenia standardowego dla analogicznych horyzontów są ponad dziewięciokrotne. Wartości ryzyka względnego realnych oczekiwanych stóp zwrotu indeksu NIKKEI 225 w zależności od długości horyzontu inwestycyjnego ilustruje rysunek 5.10.

Rysunek 5.10. Wartości ryzyka względnego indeksu NIKKEI 225

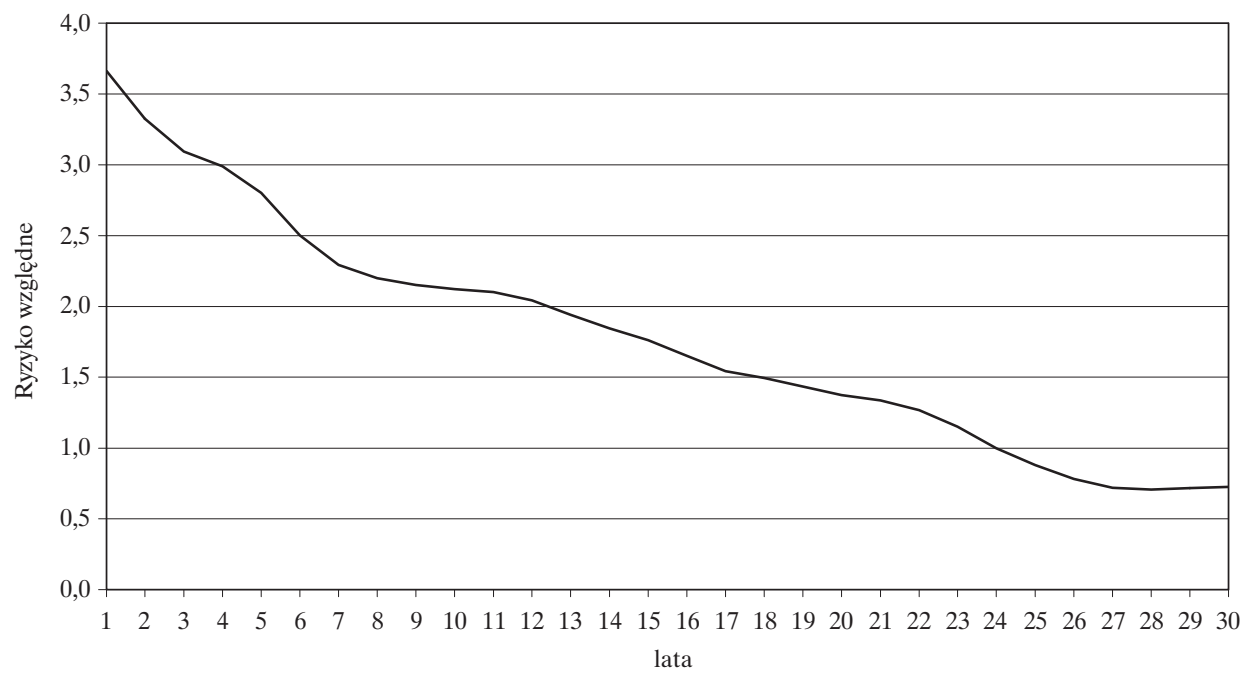

Źródło: opracowanie własne na podstawie: Global Financial Data.

Dynamikę zmiany ryzyka względnego realnych stóp zwrotu indeksu NIKKEI 225 prezentuje tabela 5.10.

Tabela 5.10. Dynamika zmiany ryzyka względnego indeksu NIKKEI 225

\begin{tabular}{|l|c|c|c|c|c|c|c|}
\hline \multicolumn{1}{|c|}{ Horyzont inwestycyjny (lata) } & $\mathbf{1}$ & $\mathbf{5}$ & $\mathbf{1 0}$ & $\mathbf{1 5}$ & $\mathbf{2 0}$ & $\mathbf{2 5}$ & $\mathbf{3 0}$ \\
\hline $\begin{array}{l}\text { Ryzyko względne indeksu } \\
\text { NIKKEI 225 }\end{array}$ & 3,66 & 2,80 & 2,12 & 1,76 & 1,37 & 0,88 & 0,73 \\
\hline Zmiana (\%) & & 23,35 & 41,97 & 51,81 & 62,49 & 75,88 & 80,16 \\
\hline
\end{tabular}

Źródło: opracowanie własne na podstawie: Global Financial Data.

Benchmark rynku japońskiego charakteryzuje relatywnie mniejsza dynamika redukcji ryzyka względnego realnych stóp zwrotu. Dynamika analizowanego parametru jest stabilna dla horyzontów inwestycyjnych 5-25 lat. Dla hory- 
zontów o długości 25-30 lat dynamika redukcji ryzyka względnego indeksu NIKKEI 225 słabnie.

\section{Podsumowanie}

Wartości ryzyka względnego realnych stóp zwrotu indeksu FTSE osiągają najwyższy poziom dla horyzontów 1-5 lat (rysunek 5.11). W dłuższych horyzontach najwyższe wartości ryzyka względnego osiągają indeks CAC 40. Poziom ryzyka względnego indeksu DAX jest najniższy dla wszystkich analizowanych horyzontów inwestycyjnych.

Rysunek 5.11. Ryzyko względne realnych stop zwrotu indeksów giełdowych

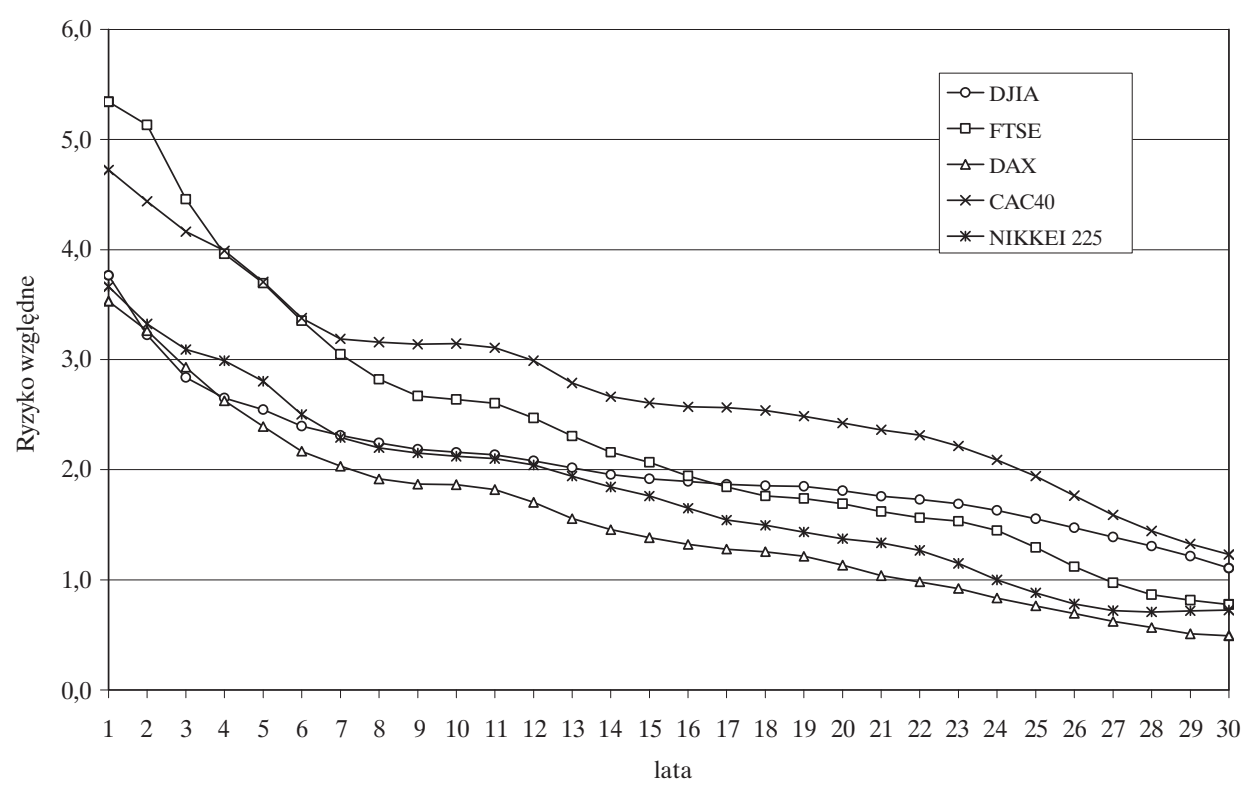

Źródło: opracowanie własne na podstawie: Global Financial Data.

W krótkich horyzontach (1-5 lat) największa dynamika redukcji ryzyka względnego realnych stóp zwrotu charakteryzuje indeksy DJIA, DAX, FTSE (32,5-30,3\%), mniejszą dynamikę wykazały indeksy CAC 40 i NIKKEI 225 $(23,4$ i $21,7 \%)$.

W dziesięcioletnich horyzontach największa dynamika redukcji ryzyka względnego charakteryzowała indeksy FTSE $(50,6 \%)$ oraz DAX $(47,2 \%)$; indeksy DJIA, NIKKEI 225 porównywalnie redukowały ryzyko względne (42,6 
i 42\%); najmniej dynamicznie następuje redukcja ryzyka względnego dla indeksu CAC $40(33,5 \%)$.

Indeksami dynamicznie redukującymi ryzyko względne realnych stóp zwrotu w horyzontach 15-letnich były: FTSE i DAX (61,4 i 60,8\%), pozostałe indeksy charakteryzuje mniejsza dynamika redukcji ryzyka względnego: NIKKEI 225 - 51,8\%, DJIA - 49\%, CAC40 - 44,8\%.

W horyzontach dwudziestoletnich najbezpieczniejsze były indeksy: FTSE i DAX (68,3 i 67,9\%), pozostałe były mniej bezpieczne NIKKEI 225 (62,5\%), DJIA $(51,9 \%)$, CAC $40(48,7 \%)$.

Horyzonty dwudziestopięcioletnie najbardziej sprzyjały redukcji ryzyka względnego indeksowi DAX (78,3\%); indeksy: NIKKEI 225 i FTSE miały porównywalny poziom przedmiotowego parametru $(75,9$ i $75,8 \%)$, jak również porównywalnie redukowały ryzyko względne indeksy: CAC 40 i DJIA $(58,9$ i $58,7 \%)$.

W 30-letnich horyzontach inwestycyjnych najbezpieczniejszymi okazały się DAX i FTSE (86,1 i 85,5\%), a następnie NIKKEI 225 (80,2\%), CAC 40 (74\%) oraz DIJA (70,5\%).

W pięcioletnich horyzontach najlepsza dynamika redukcji ryzyka względnego realnych stóp zwrotu charakteryzuje indeks DJIA; dla horyzontów 10-20 lat najbezpieczniejszy okazał się indeks FTSE. Dla indeksu DAX najlepszymi okazały się horyzonty 25-30 lat. Dla horyzontów 5-20 lat najmniejszą dynamikę redukcji ryzyka względnego zanotował indeks CAC 40, a w horyzontach 25-30 lat indeks DJIA.

\section{Bibliografia}

Allen, R. (2011). Global economic history: a very short introduction. Oxford: Oxford University Press.

Alpert, P. (1951). Twentieth century economic history of Europe. New York: Henry Schuman, cop.

Arestis, Ph., Sobreira, R. i Oreirp, J.L. (2011). An assessment of the global impact of the financial crisis. Basingstoke: Palgrave Macmillan.

Arrighi, G. (2010). The long twentieth century: money, power and the origins of our Times. London: New York Verso, cop.

Bairoch, P. (1993). Economics and world history: myths and paradoxes. Chicago: University of Chicago Press, cop.

Bernholz, P. (2003). Monetary regimes and inflation: history, economic and political relationships. Cheltenham, Northampton: Edward Elgar.

Bordo, M. (2012). Deep recessions, fast recoveries, and financial crises: evidence from the American record. Cambridge, Massachusetts: National Bureau of Economic Research.

Budd, C.H. (2011). Finance at the threshold: rethinking the real and financial economies. Farnham, England Burlington: Gower. 
Cassis, Y. (2011). Crises and opportunities (1890-2010): the shaping of modern finance. Oxford: Oxford University Press.

Clark, G.A. (2007). Farewell to alms: a brief economic history of the world. Princeton-Oxford: Princeton University Press, cop.

Eichengreen, B. (2012). The world economy after the global crisis: a new economic order for the 21st century. Singapore: World Scientific Publishing.

Ferguson, N. (2008). The ascent of money: a financial history of the world. New York: Penguin Press.

Flandreau, M., Holtfrerich, C-L. i James H. (2003). International financial history in the twentieth century: system and anarchy. Washington: German Historical Institute; Cambridge: Cambridge University Press, cop.

Fridson, M.S. (1998). It was a very good year: extraordinary moments in stock market history. New York: John Wiley and Sons.

Giersch, H.A. (1978). European look at the world economy. Kiel: Universität Kiel.

Glossner, C.L. (2010). The making of the German post-war economy: political communication and public reception of the social market economy after World War II. London-New York: Tauris Academic Studies, cop.

Greasley, D. (2011). Economics and history: surveys in cliometrics. Chichester: Wiley-Blackwell.

Haug, A.A. i Dewald W.G. (2004). Long-term effects of monetary growth on real and nominal variables, major industrial countries, 1880-2000. Frankfurt am Main: European Central Bank.

Kindleberger, C.P. i Laffargue J.P. (2008). Financial crises: theory, history, and Policy. Cambridge: Cambridge University Press-Paris: Editions de la Maison des Sciences de l'Homme.

Littlewood, J. (1998). The stock market: 50 years of capitalism at work. London: Financial Times.

Maddison, A. (2000). Monitoring the world economy 1820-1992. Paris: Organisation for Economic Co-operation and Development.

Mishkin, F.S. (2002). US stock market crashes and their aftermath: implications for monetary policy. Cambridge, Massachusetts: National Bureau of Economic Research.

Mosk, C. (2008). Japanese economic development: markets, norms, structures. London-New York: Routledge.

Pomfret, R.W.T. (2011). The age of equality: the twentieth century in economic perspective. Cambridge, Massachusetts-London: Belknap Press of Harvard University Press.

Quennouëlle-Corre, L. i Cassis, Y. (2011). Financial centres and international capital flows in the nineteenth and twentieth centuries. Oxford: Oxford University Press.

Read, C. (2010). The rise and fall of an economic empire: with lessons for aspiring economies. Basingstoke: Palgrave Macmillan.

Rhode, P.W. (2006). The global economy in the 1990s: a long-run perspective. Cambridge: Cambridge University Press, cop.

Rivoire, J. (1980). L'économie mondiale depuis 1945. Paris: Presses Universitaires de France.

Rockoff, H. (2003). Deflation, silent runs, and bank holidays, in the Great Contraction. Cambridge, Massachusetts: National Bureau of Economic Research.

Schröter, H.G. (2005). Americanization of the European economy: a compact survey of American economic influence in Europe since the 1880s. Dordrecht: Springer, cop.

Silver, M. (1995). Economic structures of antiquity. Westport, Connecticut; London: Greenwood Press, cop. 
Vickers, D. (2011). The day after the dollar crashes: a survival guide for the rise of the New World Order. Hoboken, New Jersey: John Wiley and Sons.

World Bank (2010). Global economic prospects: crisis, finance, and growth. Washington:

World Bank.

www.globafinancialdata.com.

www.world-exchange.org. 


\title{
Глава 6
}

\section{Экономическая политика после кризиса*}

\begin{abstract}
Аннотация
В место кейнсианства пришла неолиберальная доктрина, которой образцом стала политика Великобритании, называема тэтчеризмом, а в США - рейганомикой. В политике этой ставка делалась на свободное действие рыночного механизма, дерегулирование, незначительное участие государства и экономный бюджет, низкие налоги и либерализацию рынка труда. Не следовало бы пересмотреть эти основные мегатренды в глобальной экономике в ситуации последствий финансовых кризисов и финансизации мировой экономики? В статье затронуты эти существенные дилеммы развития. Авторы считают, что всесильное, бюрократизированное государство также неприемлемо, как и полностью свободный рынок, но государство, особенно в период кризиса, должно осуществлять промышленную или секторную политику, чтобы противодействовать неблагоприятным явлениям, таким как безработица или социальная исключенность.
\end{abstract}

Ключевые слова: Кризис, финансизация экономики, частная задолженность, публичная задолженность, невидимая рука рынка, роль государства, секторная политика, трилема Дэни Родрика.

\section{Economic Policy after the Crisis}

\section{Summary}

In place of Keynesianism the neo-liberal doctrine came and has become a standard policy in the UK called Thatcherism and Reaganomics in the United States. The policy was based on the free operation of the market mechanism, deregulation, the limited role of state, low taxes and liberalized labour market. However, do these fundamental megatrends in the global economy should not be reviewed in the aftermath of financial crises and world economy

\footnotetext{
Tekst ten został zamówiony i opublikowany w czasopiśmie naukowym Uniwersytetu w Nowosybirsku Idee i idealy na podstawie: A.Z. Nowak (2017). Polityka gospodarcza $i$ spoteczna po kryzysie. W: A.Z. Nowak, K. Ryć (red.). Polityka w regionach w warunkach globalizacji. Warszawa: Wydawnictwo Naukowe Wydziału Zarządzania UW.
} 
financialisation? This article takes a significant development dilemma. The authors believe that the omnipotent bureaucratic state is just as unacceptable as a completely free market. But the state, in particular periods of crises must develop an industrial policy and sectoral policy, in order to prevent such negative phenomena as unemployment or social exclusion.

Keywords: crisis, financialisation of the economy and private debt, public debt, the invisible hand of the market, the role of the state, sectoral policy, Dani Rodrik's trilemma.

\section{Введение}

В мировой экономике пока еще не видно конца турбулентности, усиленной нынешним кризисом, однако неминуемо возникает вопрос: каков урок для экономической политики следует из этой драмы для мировой экономики. В экономической и общественно-политической литературе ведутся споры об источниках, последствиях и путях выхода. Сейчас мы побольше знаем о сущности, причинах и последствиях этого кризиса. И хотя спад валового национального продукта в нынешнем кризисе не был столь большой как в кризисе рубежа двадцатых и тридцатых годов прошлого столетия, благодаря сильному противодействию правительств и центральных банков, однако ощутимые последствия продолжаются.

Сохраняется высокий уровень безработицы, говорится о втором дне кризиса, а также о многих грядущих годах экономических пертурбаций и стагнации.

В этих дискуссиях много внимания уделяется социальным последствиям кризиса. В статье мы занимаемся социальными аспектами экономической политики, а точнее социальными последствиями неолиберальной модели этой политики, особенно в сфере занятости и распределения национального дохода.

\section{1. Две фазы докризисного развития}

После периода великой депрессии 1929-1933, тридцати пяти лет напряженности и конфликтов межвоенного периода и после трагической второй мировой войны капиталистическая система прошла две фазы относительно спокойного развития. Сразу после войны в 1945-1975 годах высоко развитие страны группы ОЭСР Западной Европы и Северной Америки проходили период динамичного всестороннего развития. Экономика этого периода отличалась высокими темпами развития ВВП, практически полной занятостью, т.е. отсутствием вынужденной безработицы, низкой, сведенной до уровня ползучей, инфляцией и практически вытеснением циклического характера роста. 
Повышалось общественное благосостояние в странах Запада и тем самым росла реальная зарплата работников. Различия в уровне зарплаты рядовых сотрудников и руководящих кадров оставались относительно низкими. Укреплялась социальная безопасность работников, как в сфере стабильности занятости, так и в сфере социальных пособий. Кооперация трудовых коллективов и капитала проявлялась в разных формах участия работников в управлении, или же в участии работников в собственности предприятия, или отечественного акционерного капитала. По разному определялся капитализм этой стадии развития, используя такие прилагательные как: опекунское государство, социальная рыночная экономика, государство благосостояния или прирейнская модель капитализма и т.д.

Этот тип развития капиталистической системы провалился в середине семидесятых годов прошлого столетия. Причинами провала были как внешние факторы, так и проблемы американской экономики, пытавшейся объединить строительство великого общества с дорогостоящей войной и гонкой вооружений. Это привело к приостановлению конвертируемости американского доллара в золото, и в последствии - к распаду Бреттон-Вудской системы, что в свою очередь вызвало напряженность, пертурбации и неуверенность на денежных рынках.

Войны и напряженность на Ближнем Востоке и слабость доллара активизировали международный картель ОПЭК, который решился во много раз увеличить цены на нефть. Рост этих цен, пертурбации на денежных рынках и платежно-ценовая гонка вызвали высокую инфляцию, особенно расходного характера, но на этот раз сопровождаемую высокой безработицей. Инфляция плюс безработица выходили за пределы кейнсианской доктрины, преобладавшей в этой фазе развития капитализма. Имел место пересмотр доктрины экономической политики, опирающейся на теории Д.М. Кейнса. Существенное значение сыграли также многочисленные искажения политики опекунского государства, такие как чрезмерная бюрократизация, излишнее расточительство в публичных расходах, невысокая эффективность этой политики в условиях высокой публичной задолженности или сниженная мотивация к труду.

В место кейнсианства пришла неолиберальная доктрина, которой образцом стала политика в Великобритании, именуемая тэтчеризмом, а в Соединенных Штатах рейганомикой. В этой политике делалась ставка на свободное действие рыночного механизма, дерегуляцию, немного государства («малое государство») и экономный бюджет, низкие налоги и либерализацию рынка труда. Со временем доктрина приобрела форму определяемую наименованием вашингтонский консенсус, рекомендуемую всем странам, особенно тем, которые обращались за помощью к Международному валютному фонду и Всемирному банку. Новая политика послужила стимулом развития. 
Удалось преодолеть инфляцию, сохранить темпы экономического роста, хотя ниже чем были в предыдущей стадии, что понятно в случае стран ОЭСР, которые раньше достигли высокого уровня развития. В свою очередь мощным импульсом развития, особенно в начале этой второй фазы стали либерализация перелива капиталов и глобализация, давшие начало быстрому развитию стран, раньше относящихся к третьему миру. Странам ОЭСР предоставило это рынки сбыта и пространство для экспансии капиталов, но заодно со временем привело в напряженности и неравновесию, ставшими очагом нынешнего кризиса. Это было связано, прежде всего с последствиями перевода производства промышленных корпораций из высоко развитых стран в страны с низкими издержками труда. Действия такие привели к росту совокупной эффективности производства, как этих корпораций, так и всей мировой экономики и одновременно изменили мировое разделение труда. Это повлияло на деиндустриализацию на Западе и экономический рост стран Востока. Стало источником финансового неравновесия, вызвавшего кризис.

\section{2. Обостоятельства начала кризиса}

В настоящее время уже сложилась обширная литература на тему источников кризиса. Многие авторы гордятся тем, что они раньше заметили нарастание кризиса, предвещали его появление, предостерегали перед ним. Кто-то справедливо заметил, что были и такие, которые предусмотрели даже семь из трех последних кризисов.

Нынешний кризис заставил врасплох одинаково представителей основного русла экономии как и политиков. В свете нынешних дискуссий можно назвать многие причины усиливающейся напряженности, приведшие к кризису.

1. Нарастание различий в величине доходов между рядовыми работниками и управленческими кадрами корпораций. В предыдущей фазе эти различия были на много меньше. Глава фирмы зарабатывал в 20 раз больше чем простой работник, сейчас в ста крупных предприятиях в США глава зарабатывает в 320 раз больше (Buras, 2012). Углубились разницы между благосостоянием среднего класса, которого рост приостановился в ведущих капиталистических странах на уровне тридцатилетней давности и доходами финансовых элит, которые на самом деле присвоили результаты роста национального продукта.

2. Мощный процесс финансизации экономики. Продвигается процесс отрыва сектора финансов от сектора реальной экономики: промышленности, сельского хозяйства, торговли и других. Автономный быт финансовых процессов, а значит и финансовых операций без участия реальной экономики способствовали росту ликвидных денежных ресурсов, подпитываемых дохо- 
дами хозяйственных и финансовых элит. Финансовая игра, часто именуемая казино капитализмом, происходит в ущерб инвестициям в реальную сферу.

3. Перенос рабочих мест из продвинутых в развитии стран в страны относимые к числу возникающих рынков ослабил переговорную позицию работников в богатых странах и приостановил рост реальной зарплаты. Стагнацию реальных доходов смягчал дешевый кредит, который до определенного времени давал возможность роста потребления за счет долга. В США ипотечная задолженность для многих семей стала способом финансирования дополнительных расходов. Дома, купленные в кредит и отданы в залог могли быть обеспечением следующего кредита если их цены, и тем самым рыночная стоимость, росли. Дом, даже купленный в кредит, становился своеобразным банкоматом, например при покупке машины и других благ. И так возникали токсические активы банков ${ }^{1}$.

4. Низкие процентные ставки. Излишки свободного капитала в результате высоких сбережений жителей Китая, которые только в 2000-2006 гг. выросли с 38\% до 54\% ВВП и могли быть переведены на приобретение американских облигаций, повышая их цену и снижая рентабельность. К этому присоединились высокие сбережения других, быстро развивающихся стран Юго-Восточной Азии, серьезно пострадавших от финансового кризиса 1997 года, которого причиной была слишком низкая ликвидность ресурса активов, раскрытая утечкой капиталов. Свободные капитали нефтяных стран, размещенные в суверенных инвестиционных фондах, были увеличены на сбережения азиатов. Изобилие капитала в результате привело к низким процентным ставкам и легкой доступности кредита. Были созданы условия для возникновения чрезмерной задолженности домашних хозяйств и предприятий во многих странах, наиболее ярко проявившиеся в секторе жилищного строительства и другой недвижимости, а также на рынке товаров длительного пользования. Поощряли также к финансированию кредитом расходов публичного сектора во многих странах. Издержки обслуживания задолженности были низкими.

5. Миновала опасность инфляции. Перенос промышленного производства из богатых стран в страны с дешевой рабочей силой повлиял на снижение издержек и цен товаров, являющихся предметом международного обмена, глобальных товаров. Относится это и к части услуг, оказываемых электронным путем. Снижение показателя цен глобальных товаров и услуг тормозило рост глобального показателя инфляции в высоко развитых странах. Такое положение способствовало ведению мягкой денежной политики и экс-

1 Нынешний председатель ФРС Б. Бернанке якобы восхищался «Глубиной и изощренностью американских финансовых рынков, которые обеспечивали домашним хозяйствам доступ к капиталу в виде собственного дома» (Mankin i Taylor, 2009). 
пансивной бюджетной во многих странах. В дискуссии о прямых причинах кризиса они впрочем называются в самом начале.

6. Отсутствие урегулирований и контроля со стороны правительств и центральных банков за выработкой и использованием финансовых инструментов. Дело в финансовых инструментах, позволяющих размыть риск и осложнить его оценку. Отсутствие урегулирований и контроля позволило на высокое использование действия рычага (финансового левериджа) активов банков и финансовых институтов. Возникшие в результате этого т.н. токсичные активы подорвали достоверность финансовых институтов, привели к банкротству или к грани банкротства многие, пользующиеся хорошей репутацией, банки и страховые компании, приостановили денежные потоки и кредит. Страны ОЭСР направили сотни миллиардов долларов на спасение банков от банкротства. Правительства стран Западной Европы на спасение банков, которые приобрели токсичные американские активы, затратили суммы превышающие публичный долг. Согласно оценкам спасательные действия повлияли на рост публичного долга в среднем 60 до 80\% ВВП (Nowak, Ryć, 2010).

\section{3. Кризис публичных финансов}

Не будет преувеличением констатация, что вследствие кризиса частная задолженность превратилась в публичную. Кроме того, спад объемов производства, вызванный перемещением банковского кризиса в сферу реальной экономики, вызвал сокращение поступлений налогов в бюджеты государств при увеличенных расходах. Рост бюджетных дефицитов и публичной задолженности вызвал смятение на финансовых рынках. Имело место снижение доверия рынков к странам-должникам и спад цен облигаций, а также снижение цен облигаций и рост издержек обслуживания задолженности. В результате это привело к кризису или угрозы кризисом для публичных финансов во многих странах. Возникла некомфортная ситуация для неолиберальных экономистов и политиков - приверженцев их идей. Подвели рыночные механизмы, провинился рынок, обвинялось государство. Черный пиар, распространяемый публицистами и экономистами из банковских кругов, был направлен против опекунского государства, которое обвинялось в чрезмерной задолженности. Однако, так сложилось, что типично опекунские государства, например скандинавские страны, не страдают кризисом публичных финансов. Касается это не столько опекунских государств, сколько государств чрезмерно «дружественных» своим согражданам, готовых нести большие публичные расходы и одновременно сохранять низкие налоги. Такой дружественной страной была Греция, в которой трудно было найти чрезмерную заботливость 
и раздутые социальные привилегии, но все-таки накопила огромный публичный долг. Низкие процентные ставки поощряют к займам и финансированию социального обеспечения, а также к расширению административных структур, гарантирующих привлекательные рабочие места с одновременным доброжелательным отношением к налогоплательщикам. Государственные облигации являются хорошей инвестицией, не обремененной высоким риском, выгодной как для богатых, так и для бедных.

Оставим в стороне вопрос источников публичного долга, он стал чрезмерным во многих странах, не столько из-за размера долга, сколько нежелания рынков финансировать его. Возникают осложнения с продажей очередных транш выпуска правительственных бумаг. Факт, что это вопрос оценки рынков, а не размера публичного долга - указывает пример Японии, которая несмотря на то что у нее рекордный публичный долг, в два раза превышающий уровень японского ВВП, тем не менее у нее нет проблем с его дешевым финансированием и обслуживанием. У нее в основном займы, взятые внутри страны, затем менее податливые на воздействие спекулятивного капитала. Чрезмерная задолженность государств заставляет к жесткой экономности, тем более ощутимой для общества, чем хуже представляется эта задолженность в оценке рынков, то есть обременена большим риском для инвесторов.

Экономность, сокращающая внутренний спрос, как потребительский так и инвестиционный, тем более в условиях года экономят многие страны, являющиеся торговыми партнерами, также ослабевает экспорт. Снижение темпов роста ВВП в результате сокращающегося внутреннего и внешнего спроса, и тем более снижение размера ВВП уменьшает налоговые поступления, что разрушает усилия или ослабевает результаты усилий, предпринимаемых для достижения равновесия финансов государства. Эта круговая причинность не только не влияет на снижение долгов, но они часто продолжают увеличиваться. В результате формируется мнение, что многое делается для того, чтобы приостановить нарастание долгов. Мнение такое должно убеждать рынки об успешных перспективах оздоровления финансов и поощрять международные инвестиционные фонды к приобретению долговых бумаг по цене относительно выгодной для эмитента. Мнение рынков, предупредительно говоря, а по сути мнение международных финансовых спекулянтов, становится важнее чем цели развития стран и стремления их граждан. Политика экономности и ограничения бюджетных дефицитов одновременно и во многих странах неизбежно приводит в одних к замедлению темпов роста, в других, особенно жестко ограничивающих расходы таких как Греция, Италия, Испания, к рецессии. Ожидается в течение нескольких лет замедление темпов роста экономик наиболее развитых стран. И это не смогут предотвратить ни центральные банки, смягчающие денежную политику. Спрос на кредиты со стороны как домашних хозяйств, так и предприятий снижается. Первые уже погрязли 
CZĘŚĆ I. Wobec nowych wyzwań globalizacji

в долгах, учитывают угрозу потери работы и зарплаты в условиях падающей конъюнктуры, вторые - не стремятся к важным инвестициям в условиях низкого спроса и мало благоприятных перспектив. Вялый экономический рост не обещает роста занятости и сокращения безработицы.

\section{4. Рыночный механизм и необходимость сокращения безработицы}

Когда экономический рост не в состоянии обеспечить возможно полной занятости, нельзя бесконечно применять принципы либеральной экономики и поддерживать правила вашингтонского консенсуса, т.е. жесткой денежной политики, незначительного участия правительства и низких налогов, гибкого трудового законодательства, дерегулирования, приватизации и полного открытия рынков. Нет единого чудотворного средства для каждого состояния экономики. Неолиберальные экономисты, еще недавно преобладающее направление макроэкономии, повторяют как заклинание: «чтобы оживить экономику надо сокращать налоги и привести к более гибкой занятости». Повторяют это как в ситуации хорошей конъюнктуры докризисного периода, во время кризиса и в условиях послекризисного замедления развития или прямо депрессии. В разных условиях развития ждут всегда одних и тех же результатов. Обозначает это не только верность правилам вашингтонского консенсуса, но также его углубление, т.е. больше трудовых договоров на неопределенный срок, называемых «мусорными», более низкие трудовые издержки, более низкая минимальная зарплата, ведь труд - это издержки, которые следует снижать. Зато вознаграждения менеджеров являются ценой управления активами и зависят от их рыночной стоимости (Mess, 2012).

В случае менеджеров действует принцип - хорошая цена за хороший товар. Зарплата работников - это лишь издержки и как все издержки следует их ограничивать, даже тогда, когда маржа прибыли растет а финансовая аккумуляция не расходуется на инвестиции, а накапливается в виде ликвидных активов. Премиальные менеджеров не тратятся на потребление, а нераспределенная прибыль корпорации на инвестиции, тем самым ограничивается внутренний спрос. Рост ликвидных активов углубляет процесс финанзизации экономики, отрывает сферу финансов от реальной сферы.

Говоря о необходимости действий, выходящих за рамки правил вашингтонского консенсуса, мы не хотели намекать на отказ от принципов рыночной экономики.

Исторический опыт доказывает, что действие «невидимой руки» рынка является лучшим способом удовлетворения нужд общества. Цены, формирующиеся на рынке, отражают, как стоимость блага или услуги для приобретателя (общества), так и издержки этого блага или услуги для производителя- 
поставщика (также общества). Руководствуясь рыночной ценой учитываем выгоды и издержки своих действий. читая популярный учебник: «... цена так влияет на решения отдельных предпринимателей и домашних хозяйств, что они ведут себя таким образом, который во многих случаях обозначает максимизацию благосостояния общества в целом» (Heller i Kotliński, 2012; Mankin i Tayler, 2009). Следует подчеркнуть слова «во многих случаях». Рыночный механизм влияет на размер ВВП и тем самым на благосостояние общества в такой мере, в какой зависит оно от продукта в пересчете на душу населения. Согласно логике рассуждения, если мы нарушим действие рыночного механизма, хотя бы обложением налогом, тогда оказываем пагубное воздействие на рыночную аллокацию ресурсов. Нарушая механизм образования равновесия сил, мы тем самым уничтожаем, хотя бы частично, эффекты действия «невидимой руки». Тем более если бы мы пытались регулировать цены, например, продуктов питания или квартплаты.

Возникает некоторая непоследовательность в предпосылке. «Невидимая рука» может оказаться эффективной только тогда, когда действует государство и взимает налоги. Ведь государство создает законы, требует их соблюдения и гарантирует безопасность, и именно это является основным условием действия рынка. В самом начале доктрины свободного рынка возникает необходимость отделения максимум продукта, которая делает возможным рыночную расценку благ и рыночную аллокацию, от благосостояния, в которое входит не только стоимость продуктов, но также безопасность, общественный порядок, достигаемый за счет налогов.

Кроме того, как известно, следует учитывать:

- несовершенство рыночной аллокации ресурсов, особенно в сфере инфраструктуры материальной и социальной (здоровье, образование);

- воздействие внешних эффектов, т.е. побочные последствия деятельности одних лиц, которые отрицательно воздействуют на благосостояние других лиц;

- неблагоприятные последствия монопольного преимущества, влияющие на расценку ресурсов и благосостояние других.

Не нуждается в широком обосновании утверждение, что благосостояние не отождествляется с размером ВВП в пересчете на душу населения, хотя и зависит от размера ВВП. Названные выше несовершенства в действии рынка косвенно это подтверждают. Стоит только отметить и другие существенные обстоятельства углубления этих расхождений между объемом продукта и благосостоянием или же качеством жизни.

Во-первых, удовлетворение основных материальных нужд на высоком уровне - у современного массового потребителя такие потребности, какие придумает производитель, а потом возбудит их в потребителе. Такое действие нельзя считать плохим, раз оно чаще всего повышает комфорт жизни чело- 
века и потребителя. Но возрастает количество злоупотреблений, следующих из доминирования производителя над потребителем. Неравенство это углубляет разницу между объемом продукта на душу населения и благосостоянием, заодно влияя на необоснованно высокое израсходование необновляемых ресурсов и нанесение вреда окружающей среде.

Во-вторых, рыночный механизм может вызывать и углублять социальное неравенство, приводить к глубокой стратификации по доходам. Эта проблема широко обсуждается уже давно и вызывает многочисленные разногласия. Одни противопоставляют эффективность социальному эгалитаризму, другие убеждают в необходимости широкого понимания эффективности общественной системы, в которой неравенство шансов кумулятивно углубляется неравенством доходов и приносит отрицательные последствия для развития, также в экономическом понимании.

Примером неэффективности рынка является безработица, хотя неолиберальные экономисты готовы винить в этом деятельность государства или профсоюзов.

Экономический рост, особенно анемичный, в условиях свободного рынка не обязательно приводит к сокращению безработицы, а как раз наоборот, даже ее увеличивает. И дело тут не только во влиянии технического прогресса на уровень занятости, как хотя бы заявленная в прошлые годы Дж. Рифкиным (Новак и Рычь, 2014, с. 69-77) проблема роста безработицы, вызванной бурным ростом производительности труда. Речь идет и об упомянутой раньше дезиндустриализации высоко развитых стран в пользу новых рынков, неприспособленности ресурсов рабочей силы в западных странах к новому труду в высоко продвинутых секторах.

Неизбежно нарастает проблема лишних людей в свете правил рыночной экономики. Лишние люди не создают валовой продукт. Лица, временно теряющие работу, вследствие процесса гистерезиса в значительной их части, остаются безработными на всегда. Лишние машины сдаются в металлолом. Лишняя рабочая сила должна быть освоена и использована для повышения благосостояния внерыночным способом, если рынок не сумеет включиться в процесс образования ВВП.

\section{5. Необходимость восстановления секторной политики}

Чтобы получить состояние близкое к полной занятости в экономической политике государства надо делать ставку на секторы, создающие рабочие места, даже тогда, когда рыночный эффект отрицательный. Это происходит потому, что доходы не покрывают издержки, но занятые способствуют росту благосостояния, не измеримого в рыночных категориях. 
Наверное, уже слишком поздно на восстановление промышленной политики и создание рабочих мест путем покровительственной поддержки развития промышленности. На такое не позволяет высокий уровень интеграции национальной экономики в мировую экономику, членство в ВТО, Евросоюзе и обязательства, следующие из других международных соглашений. В этих обстоятельствах надо использовать некоммерческие секторы, такие как образование, здравоохранение, наука и культура. Важная также политика поддержки семье, развитие сектора ухода за маленькими детьми.

Секторная политика является прочным элементом рыночных экономик, продвинутых в развитии. Примером может служить сельскохозяйственная политика, оцениваемая должным образом в большинстве стран. Динамичное развитие второго сектора, т.е. промышленности и строительства позволило оставить в стороне неэффективное сельское хозяйство. В этом отношении ярким примером служит Япония, в фазу наиболее динамичного развития сделав ставку на мощный экспортный сектор промышленности, сохранила крупные сферы неэффективности в сельском хозяйстве и в услугах.

В настоящее время громко прозвучал вопрос сектора внутренней торговли в Индии. Правительство планирует открыть торговлю для сетей гипермаркетов, что угрожает мелкой торговле, обеспечивающей рабочими местами 220 миллионов индусов, что вызывает сильные протесты в ее защиту.

Некоммерческие секторы экономики, которые мы назвали в качестве мест дополнительной занятости для разрядки напряженности на рынке труда, вызванной безработицей, не являются пережитком традиционной экономики. Они могут стать прочным элементом, или даже ведущим в экономике. Существует обширная литература, посвященная роли образования, науки, здравоохранения или же здоровых демографических пропорций в общественноэкономическом развитии в длительный период. Проблема в том, что нынешние усилия в пользу экономии, связанные с кризисом публичных финансов, вызывают действия правительств в совершенно другом направлении. Это прежде всего сокращение бюджетных расходов и это касается также той части, которая была выделена, в частности, на здравоохранение, образование, науку и культуру, способствуя росту безработицы.

Правительства лишь в незначительной степени, и не все, решаются на повышение налогов, чтобы добиться бюджетного равновесия, особенно подоходного налога. Изменение нынешней политики не только возможно но и желанно, хотя не будет простым и быстрым. Решающими могут оказаться политические факторы, возникла необходимость снять «Золотую смирительную рубашку».

Золотой смирительной рубашкой Томас Фридман назвал стратегию правительств, жестко внедряющих стратегию соответствующую вашингтонскому консенсусу, а именно: здоровые деньги, низкие налоги, гибкое трудовое 
законодательство, частная и свободная торговля в расчете на доверие рынков, которое позволит привлечь капитал, добиться благосклонности инвестиционных фондов и хорошего мнения рейтинговых агентств (Новак и Рычь, 2016). Смирительная рубашка ограничивает действия правительств в области экономической политики.

Верность этим принципам, хорошая репутация и доверие рынков являются политической рекомендацией для правительств. От этих принципов не откажется также и оппозиция, когда придет к власти, в связи с тем политика соответствует ожиданиям рынков и собственных финансовых элит, и необязательно - о чем мы упоминали выше - целям и стремлениям населения. У правительств достаточно сильные аргументы (а скорее алиби), чтобы продолжать такую политику.

Секторная политика, делающая ставку на развитие некоммерческих публичных услуг, финансируемых из государственного бюджета, при чем на средства полученные от налогов, а не методом «дружественного государства», обозначает отказ от защитного наряда.

В пользу отказа от этой односторонней, и по существу, оппортунистской политики в пользу политики учитывающей развитие сектора публичных услуг свидетельствуют, по-нашему, важные аргументы.

1. Нет доказательств, что снижение подоходного налога, особенно сокращение налоговой прогрессии, даст рост занятости. Также нет доказательств на то, что более высокие подоходные налоги и большая прогрессия приостановит предпринимательство и инновационность. Статистические исследования этих зависимостей в обоих случаях принесли неоднозначные результаты. Обозначает это, что в случае кризиса публичных финансов самым лучшим способом для их оздоровления, не является сокращение расходов на публичные услуги, потому что оно снизит отечественный спрос и углубит рецессию. Лучшим способом является рост налоговых поступлений, особенно от подоходного налога. Конечно, это не обозначает, что можно пренебрегать рационализацией расходов на публичные услуги.

2. Затраты на развитие и соответствующее число яслей, детских садов, школ, а также помощь работающим матерям и многодетным семьям являются лучшей инвестицией, чем инвестирование на бирже средств пенсионных фондов. Большое число здоровых и хорошо образованных будущих работников является надежной гарантией будущих пенсий.

3. Много аргументов свидетельствует, как в пользу пронатальной политики, так и в пользу развития и качественных преобразований в публичной системе образования. Повышение уровня публичных школ является условием успешного выравнивания шансов молодежи. Школы всех уровней, в том числе вузы, формируют главный фактор будущего развития: человеческий капитал. Увеличенные затраты на эту цель надо, конечно, поддерживать продуманной организацией и управлением. 
4. Затраты на здравоохранение и уход за пожилыми людьми значительно выросли во всех странах, также в тех, которые в экономической политике руководствуются неолиберальными принципами. Принуждает к этому процесс старения населения высоко развитых стран, а также прогресс в области медицинских технологий, как правило дорогостоящий, внедряемый в здравоохранении. Система здравоохранения и ухода за больными и людьми с ограниченными возможностями открывает широкие перспективы для социально обоснованного роста занятости.

5. Широкой сферой профессиональной активности может оказаться также активизация культуры, отдыха и спорта. Увеличенные и разумно расходованные средства на эту цель могут принести эффекты похожие на затраты на образование, науку и здравоохранение в длительной перспективе. Они окажут благоприятное воздействие на формирование человеческого и социального капитала.

6. Затраты на услуги и пособия из публичных средств, как мы констатируем, способствуют росту благосостояния и улучшению качества жизни населения, не находящие отражения в показателе валового продукта, но в продолжительной перспективе они поспособствуют росту валового продукта. К сожалению, эффекты в узко понимаемом экономическом смысле, появятся в будущем, а затраты надо нести уже сейчас. И эти затраты необходимы, как для улучшения благосостояния, так и во избежание социальной напряженности и конфликтов, которые может вызвать сохраняющаяся высокая безработица, особенно среди молодежи и опасный рост социального неравенства. Бедность, и исключенность не будут безопасно сосуществовать наряду с растущим обогащением и демонстративным потреблением элит. И также по этим причинам возникает необходимость сокращения различий в доходах путем системы налоговой прогрессии. Средства вырученные от повышенных налогов должны финансировать увеличенные публичные расходы.

\section{6. Шансы секторной политики и трилема Дэни Родрика}

Постулат финансирования программ профессиональной активизации публичным сектором экономики еще недавно был объектом насмешек экономистов основного направления и следующих их мнению политиков, а также СМИ, формирующих общественное мнение. Эпитет провозглашения социализма не был самым самим обидным.

Положение изменилось после возникновения нынешнего кризиса. До общественного сознания дошла информация о диапазоне доходов и росте этих различий за весь период неолиберальной фазы развития капитализма, начиная 
с середины семидесятых годов прошлого столетия. Рост этих различий не приостановился и в период кризиса. Общество во все большей мере отдает себе отчет в последствиях симбиоза политических и финансовых элит, заменяемости карьер в бизнесе и политике, роли лоббистов в процессе законодательства и т.п. Связи политики и бизнеса способствуют защите высоких доходов от перераспределения во имя поддержки экономического роста, что противоречит действительности.

Осознание такого положения не является необходимым условием для его изменения, но первым шагом в этом направлении. Это осознание породило движение возмущенных, которое сейчас не имеет существенного значения, кроме медийного эффекта. Самая сложная проблема предполагаемых изменений следует из масштабов международной экономической интеграции и из финансизации мировой экономики, а также этой «золотой смирительной рубашки».

В условиях свободы перелива капитала взыскание уплаты повышенных подоходных налогов с плательщиков с самыми высокими доходами может привести к бегству налогоплательщиков. И вопрос не только в бегстве налогоплательщиков или переводе потери прибыли сокращенной на размер уплаченного налога на клиентов, в случае субъектов являющихся монополистами. Этот вопрос шире представляет трилема Дэни Родрика, которую мы представляем с немного измененным описанием.

Рисунок 6.1. Трилема Дэни Родрика

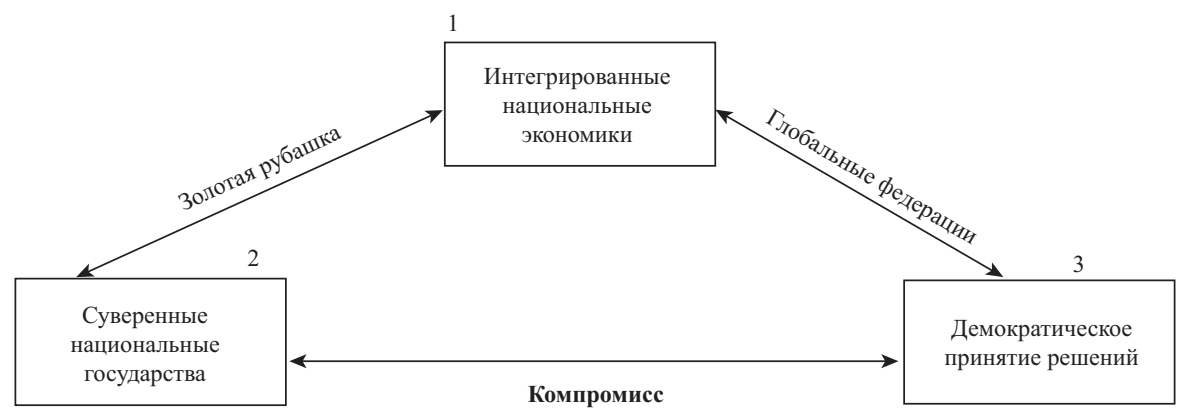

Источник: разработано на основании (Новак и Рычь, 2016).

Также как и в случае трилемы открытой экономики в терминологии Обстфельда и Тэйлора существует т.н. невозможная троица: 1) международная мобильность капитала; 2) жесткий валютный курс, регулируемый государством; 3) автономная денежная политика правительства. Возможным является сосуществование двух из трех обстоятельств. Если имеем дело с международной 
мобильностью капитала, в которой участвует страна (1), то она может обладать лишь одной из двух свобод: свободой формирования валютного курса (2) или свободой денежной политики (3). Но если мы хотим располагать как свободой становления курса валют, так и свободой монетарной политики, мы должны прекратить свободу перелива капитала.

Похожее положение в трилеме Родрика. Если мы принадлежим к интегрированной мировой экономике (Buras, 2012) и у нас суверенное национальное государство (Hellainer, 2011), тогда не можем ожидать, что решения в экономике будут приниматься в результате процедур демократического выбора в этом государстве (Heller i Kotliński, 2012). Выбор под диктовку «мировой федерации», которая формально не существует, но ее создают международные институты, вкоторых мы участвуем (напр. Международный валютный фонд или Всемирный банк) и прежде всего рынки капитала.

В свете этой трилемы свобода уклонения от налога, возложенного «алчным правительством» не единственное и не самое главное препятствие в повышении налогов для самых богатых. Важно также мнение самой «федерации», т.е. финансовых рынков о правительстве, принимающем такого типа решения. Правительства могут быть и наказаны за «плохие нравы» по отношению к финансовым элитам, также само за расточительство и недостаточную экономию. Ощутимым наказанием является отказ в инвестиционных фондах для финансирования публичного долга, и в результате вынужденная отставка правительств. Касается это также государств не сильно обремененных долгами. Такого типа зависимость суверенных национальных государств от поведения рынков способствует упрочению сильной дифференциации доходов и росту финансизации экономики, влияет на углубление неравенства в доходах внутри государств.

Интерпретация трилемы Родрика все-таки позволяет увидеть шансы на изменение. «Золотая смирительная рубашка» со временем будет становится маловатой, а решения международных рынков не будут восприниматься правящими элитами с таким смирением как сейчас.

Дэни Родрик когда писал об ограничении доступа к политическим решениям на национальном уровне, ссылался на аналогию к предыдущей экономической интеграции периода золотого стандарта в монетарной системе государств. «В кульминационный период стандарта золота ограниченная домена национальной политики (и характерная для нее опора на элиты) гарантировала, что внутренняя монетарная политика могла быть полностью подчинена нуждам сохранения паритета золота. В межвоенный период, когда выборные права распространились на всех и рабочие стали организоваться, национальные правительства признали, что дольше сохранять экономическую ортодоксию стан- 
дарта золота уже не смогут. Когда необходимость полной занятости столкнулась с нуждами стандарта золота, тот уступил место» (Новак и Рычь, 2016, с. 268).

Приведенный выше пример является грозным предупреждением для судеб международной интеграции и глобализированной экономики. Знаем, что случилось после распада золотого стандарта. Частичный распад Бреттон-Вудской системы не был слишком опасным, наверно благодаря «благотворной гегемонии» США и американского доллара (Hellainer, 2011, с. 268). Новый порядок опирался уже не на золото, а на доверие к Америке и ее валюте. Также и в этом случае можно надеяться, что освобождение от уз трилемы не будет последствием бунта рабочих ни протестов возмущенных а бунта правительственных элит, что позволит ввести международные установления и разумный компромисс для укрощения диктата рынков.

Если прогрессивная налоговая система поспособствует укреплению публичных финансов и одновременно приведет к сокращению разницы в доходах, тогда могут взять верх преимущества косвенных налогов. Благодаря налогам на потребление возможным будет повышение уровня жизни обществ при сокращенном спросе на невозобновляемые ресурсы природы и снижение деградации окружающей среды.

В настоящее время повышение НДС и других косвенных налогов в отдельных странах являются демонстрацией этой «золотой смирительной рубашки», а проще говоря проявлением оппортунизма правящих. Такой налог легче ввести по политическим соображениям. Однако, сокращение реальных доходов и потребительского спроса малообеспеченной части населения ослабевает оживление экономики и способствует углублению подоходной стратификации.

Наиболее противоречивым вопросом является роль национального государства и его политики. Представленные выше рассуждения указывают на необходимость увеличения роли государства в экономике. Мы осознаем как преимущества так и недостатки «малого» государства, так и достоинства и недостатки свободного рынка. Бюрократизированное всесильное государство также неприемлемо как и вполне свободный рынок. Пока никто не кодифицировал правила государства золотой середины. Фрэнсис Фукуяма (Ratajczak, 2012) обычно смело высказывающий мнение о настоящем и будущем времени замечает, что существует необходимость заново придумать государство, но он сам слишком мало сообразительный, чтобы представить себе такое государство.

До нынешнего кризиса слишком много власти было оставлено в руках рынка. Сейчас заметно, что процесс отступления государства и растущего доминирования рынка следует повернуть, но также внимательно следить за возвращением государства. Это задача для общественного мнения и в том числе, а может быть прежде всего, для экономических наук и управления. 


\section{Библиография}

Buras, P. (2012). Ulica zmieni świat (wywiad z Wolfgangiem Streeckiem). Gazeta Wyborcza, 5-6 maja.

Hellainer, E. (2011). Globalne ekonomie polityczne. Kraków: Wydawnictwo Uniwersytetu Jagiellońskiego.

Heller, J. i Kotliński, K. (2012). Trwała destabilizacja finansów publicznych a stopa bezrobocia w wybranych krajach Unii Europejskiej. Studia Europejskie, 64 (4).

Mankin, N.G. i Taylor, M.P. (2009). Mikroekonomia. Warszawa: PWE.

Mess, H. (2012). Forum z 13 września.

Новак, А.З. и Рычь, К. (2014/5) Европа нуждается в либеральном Кейнсе. Философия хозяйства, Москва,: 69-77. IS

Новак, А.З. и Рычь, К. (2016). Злоты или евро? В: Философия хозяйства. Москва.

Nowak, A.Z. i Ryć, K. (2010). Euro will be later - Costs or Benefits? W: Problemy nacjonalnoj strategii. Moskwa: Wydawnictwo Gosudarstwiennyj Institut Strategiczeskich Isliedowanii.

Ratajczak, M. (2012). Finansyzacja gospodarki. Ekonomista, (3).

Rifkin, J. (2003). Koniec pracy. Schytek sity roboczej na świecie i poczatek ery postrynkowej. Wrocław: Wydawnictwo Dolnośląskie.

Rodrik, D. (2011). Jedna ekonomia, wiele recept. Warszawa: Wydawnictwo Krytyka Polityczna.

Rodrik, D. (2011). The Globalization Paradox. New York-London: Norton \& Company, Inc.

Rzeczpospolita (2012), 18 września.

Stasiński, M. (2012). Państwo sztywne jak fabryka Forda (wywiad z Francisem Fukuyamą). Gazeta Wyborcza, 2-3 czerwca. 



\section{Część II}

\section{Polskie dylematy rozwojowe}

W poszukiwaniu konkurencyjności strukturalnej 



\title{
Strategia na rzecz Odpowiedzialnego Rozwoju dla polskiej gospodarki*
}

\begin{abstract}
Streszczenie
Polska gospodarka w ostatniej dekadzie rozwija się dynamicznie na tle całej Unii Europejskiej. Istnieją dobre perspektywy dla dalszego szybkiego jej rozwoju, ponieważ coraz lepsze efekty przynosi Strategia na rzecz Odpowiedzialnego Rozwoju, realizowana przez rząd polski. Twórca tej strategii premier Mateusz Morawiecki twierdzi, że powstały przesłanki do stabilnego i satysfakcjonującego w kolejnych latach wzrostu dochodu narodowego, a jednocześnie postępuje poprawa spójności w wymiarze społecznym, ekonomicznym i terytorialnym. Rozdział ten podejmuje problematykę związku pomiędzy ambitnym programem rządowym a potencjalnymi wyzwaniami dla tego programu.
\end{abstract}

Słowa kluczowe: Strategia na rzecz Odpowiedzialnego Rozwoju, Unia Europejska, globalizacja, reindustrializacja, wyzwania zewnętrzne, imigracja.

\section{Strategy for Responsible Development in the Polish economy}

\section{Summary}

In the last decade, the Polish economy has been developing dynamically compared to the entire European Union. There are good prospects for further, fast and stable development of economy. The Strategy for Responsible Development, implemented by the Polish government, brings better and better results. The author of this strategy, Prime Minister Mateusz Morawiecki claims that the conditions for a stable and satisfactory increase in the national income in the coming years have been created, and at the same time the

Wiele wątków zawartych w tym tekście zostało między innymi wcześniej podjętych w rozdziale pt. Nowa Ekonomia Strukturalna a dylematy rozwoju gospodarki. W: J.Y. Lin, A.Z. Nowak (red.). (2017). Nowa ekonomia strukturalna wobec krajów mniej zaawansowanych. Warszawa: Wydawnictwo Naukowe Wydziału Zarządzania UW. 
improvement of cohesion in the social, economic and territorial dimensions is progressing. This article deals with the relationship between an ambitious government program and potential challenges for that program.

Keywords: Strategy for Responsible Development, European Union, globalization, reindustrialization, external challenges, immigration.

\section{Wprowadzenie}

Jest faktem bezspornym, że podstawowe wytyczne dla polityki gospodarczej ulegają pewnym modyfikacjom w wielu krajach świata. Choć nadal takie kanony ekonomiczne, jak: utrzymanie dyscypliny finansowej, zrównoważony deficyt budżetowy, liberalizacja zasad handlu światowego, zniesienie przeszkód dla bezpośrednich inwestycji zagranicznych, aby firmy zagraniczne konkurowały z krajowymi na równych zasadach, deregulacja i prywatyzacja, to wciąż ważne przesłanki wzrostu gospodarczego, nie są jednak przyjmowane wszędzie i realizowane bezkrytycznie (Nowak, 2013).

Obecnie istnieje coraz większa świadomość, że choć Adam Smith miał rację stwierdzając, że wolny rynek jest przyszłością gospodarki, i jest jej niezwykle ważnym regulatorem, to zarazem wiele decyzji podejmowanych na globalnym rynku prowadzi nie tylko do oczekiwanych i pożądanych rezultatów.

Globalizację obciąża się między innymi winą za utratę miejsc pracy w krajach wysoko rozwiniętych, przede wszystkim w przemyśle, w wyniku przenoszenia produkcji do krajów o niskich kosztach pracy oraz z powodu konkurencji tanich producentów z krajów słabo rozwiniętych, intensywnie rozwijających produkcję przemysłową. Tym sposobem globalizacja, poza korzyściami w wielu miejscach na świecie, przyczynia się do wzrostu bezrobocia, pogarsza pozycję negocjacyjną pracowników najemnych w krajach wysoko rozwiniętych, co skutkuje stagnacją zarobków i dochodów realnych pracowników i klasy średniej.

Efekty wzrostu gospodarczego rozkładają się nierównomiernie - przyrastający produkt krajowy brutto trafia w większości do wąskiej warstwy właścicieli kapitału, wysokiej rangi menedżerów, zwłaszcza sektora finansowego (Dornsbuch, 2000). Ograniczony niskimi dochodami popyt konsumpcyjny znacznej części społeczeństwa oraz wysokie oszczędności warstw najwyżej sytuowanych w hierarchii dochodów stwarzają układ spowalniający tempo wzrostu. Ograniczony popyt konsumpcyjny nie sprzyja inwestycjom, a wysokie oszczędności, nie wykorzystane na powiększenie zdolności wytwórczych, powiększają zasoby rynków finansowych, bądź są inwestowane w innych krajach.

W wyniku globalizacji może następować ubytek miejsc pracy w przemyśle. Dotyczy to nie tylko przemysłu krajów najwyżej rozwiniętych, lecz może również 
wystąpić w krajach mniej, czy średnio zaawansowanych w rozwoju, wszędzie tam, gdzie koszty pracy są wyższe (Ryć, Nowak, 2017).

Polska należy do tej grupy państw, które proces internacjonalizacji, czyli umiędzynarodowienia swoich gospodarek, wiążą z transformacją systemu politycznego i ekonomicznego po 1989 roku, z wstąpieniem do Unii Europejskiej w 2004 roku, ale także z ogółem procesów o charakterze globalnym, prowadzących do postępującej współzależności i integracji państw.

Otwartość polskiej gospodarki, jej integracja z partnerami w Unii Europejskiej, to szczególnie ważne przesłanki modernizacji Polski, i w ogólnym bilansie, jej sukcesu w globalnym otoczeniu ekonomicznym. Wciąż jednak decydującym czynnikiem rozwoju społeczno-gospodarczego kraju pozostaje mądra i przemyślana strategia rozwojowa, która zapewniałaby trwałe i solidne podstawy do długofalowego, zrównoważonego wzrostu gospodarczego.

\section{1. „Konkurencyjna Polska. Jak awansować do światowej ligi gospodarczej" - diagnoza dla Polski}

Najbardziej interesujące diagnozy, dotyczące stanu polskiej gospodarki po trzydziestu latach transformacji, ale także krytyczne oceny dotychczasowego modelu rozwojowego Polski, wraz z wnioskami zmian i reform, pojawily się głównie w trzech opracowaniach analitycznych.

Jedna z zasadniczych konkluzji raportu „Konkurencyjna Polska: jak awansować do światowej ligi gospodarczej” (raport został opracowany przez zespół niezależnych ekspertów pod redakcją Jerzego Hausnera w 2013 roku) stwierdza, że trwający wówczas kryzys światowy i wynikające z niego problemy dla polskiej gospodarki stawiają na porządku dziennym pilne i konieczne podjęcie takich strukturalnych i systemowych działań, które pozwolą nie tylko ożywić gospodarkę, lecz także wprowadzić ją na ścieżkę długookresowego wysokiego wzrostu.

Według autorów raportu pełniejsze wykorzystanie potencjału rozwojowego pozwoli w konsekwencji zwiększyć tak pożądaną konkurencyjność polskiej gospodarki oraz zapewnić jej trwałą obecność w gospodarczym i politycznym trzonie Unii Europejskiej. Jednocześnie konieczne jest podjęcie takich działań, które uchroniłyby polską gospodarkę przed spowolnieniem tempa wzrostu wydajności i utknięciem w tzw. pułapce średniego poziomu rozwoju (middle income trap).

Osiągnięcie takiego celu, zdaniem autorów raportu, wymaga prowadzenia całościowych i skoordynowanych działań, które określa się w literaturze jako nową politykę przemysłową lub nową politykę strukturalną. Chodzi tu o całokształt zmian instytucjonalnych, które tworzą zespół bodźców i jednocześnie środowisko sprzyjające poprawie konkurencyjności gospodarki. 
Zarazem odpowiedzią na światowy kryzys nie będzie szybkie pojawienie się globalnych mechanizmów międzynarodowego współzarządzania. Droga wiedzie przez działania każdego państwa w obszarze własnej gospodarki i równoczesnej międzynarodowej współpracy, po to by odrzucić rozwiązania autarkiczne i protekcjonistyczne oraz poszukiwać rozstrzygnięć potrzebnych dla gospodarki otwartej, zdolnej do konkurencji i kooperacji.

Tak zwany raport Hausnera trafnie dowodzit, że istnieje kwestia strukturalnych cech polskiej gospodarki i właśnie dlatego trzeba zdecydowanie zdobyć się na strategiczną refleksję rozwojową, wdrożyć program prokonkurencyjnej polityki strukturalnej, w tym nowej polityki przemysłowej, oraz doprowadzić do strukturalnej zmiany, czyli proinnowacyjnej reorientacji polskiej gospodarki.

Jak stwierdza ten dokument, coraz bardziej nowoczesna i kompatybilna polska infrastruktura powinna stać się ważnym ogniwem wspomagającym tę reorientację polskiej gospodarki. Jak na razie, jest to jeszcze w dużej mierze postulat nie podjęty do realizacji.

\section{2. „Polska 2030. Trzecia fala nowoczesności. Długookresowa Strategia Rozwoju Kraju"}

Diagnozę stanu polskiej gospodarki, ale także prezentację listy działań związanych z realizacją poszczególnych strategicznych zadań polityki gospodarczej w Polsce, zawiera także dokument analityczny „Polska 2030. Trzecia fala nowoczesności. Długookresowa Strategia Rozwoju Kraju” (dokument ten powstał w Ministerstwie Administracji i Cyfryzacji 11 stycznia 2013 roku w Warszawie).

Głównym celem tego dokumentu jest - jak wskazują jego autorzy - poprawa jakości życia Polaków mierzona zarówno wskaźnikami jakościowymi, jak i wartością, a także tempem wzrostu PKB w Polsce. Długookresowa Strategia Rozwoju Kraju, która ma ten cel zrealizować, została ujęta w perspektywie do 2030 roku. Dokument ten wyróżnia się próbą uwzględnienia głównych trendów, wyzwań i scenariuszy rozwoju społeczno-gospodarczego kraju, kierunków przestrzennego zagospodarowania kraju, z uwzględnieniem zasady zrównoważonego rozwoju.

Stąd też w analizie wydobyty został element trzeciej fali nowoczesności - czyli kolejnego etapu rewolucji technologicznej, dokonującej się na świecie. Tym samym Długookresowa Strategia Rozwoju Kraju jest w zamierzeniu dokumentem analitycznym, ale jednocześnie rekomendacyjnym, stanowiącym opis pewnego projektu cywilizacyjnego, zorientowanego na przyszłość, w perspektywie do 2030 roku.

W sprawie trzech obszarów rozwoju strategicznego dla Polski dokument ten w zasadzie potwierdza zalecenia większości polskich ekonomistów oraz socjolo- 
gów, a także zawartość wspomnianego wcześniej tzw. raportu Hausnera. Rozwój Polski powinien odbywać się równocześnie w trzech głównych kierunkach:

1) konkurencyjności i innowacyjności gospodarki (modernizacji);

2) równoważenia potencjału rozwojowego regionów Polski (dyfuzji);

3) efektywności i sprawności państwa (efektywności).

W każdym z tych trzech obszarów strategicznych zostały określone cele do realizacji. Tak więc $\mathrm{w}$ obszarze pierwszym, który dotyczy konkurencyjności i innowacyjności, a więc modernizacji Polski, cele i kierunki obejmują:

- pobudzanie innowacyjności, efektywności gospodarki i kreatywności ludzi. Interwencja państwa powinna dotyczyć przede wszystkim edukacji: poczynając od opieki przedszkolnej po szkolnictwo wyższe, ale również wspierania badań i nauki, tak aby podnieść ich dotychczasową jakość i efektywność.

Ważne jest też tworzenie skutecznych instrumentów inżynierii finansowej i wzmacnianie instytucji otoczenia biznesu, poprawa sprawności funkcjonowania administracji państwowej i samorządowej oraz znoszenie barier legislacyjnych i administracyjnych, blokujących lub spowalniających rozwój firm;

- przyspieszenie przemian technologicznych, dlatego aby projekt „Polska Cyfrowa" nie był zapisany tylko na papierze należy podjąć dalsze niezbędne inwestycje infrastrukturalne w szerokopasmowy Internet, dostępny dla wszystkich. Zwiększy to szanse rozwoju obszarów peryferyjnych. Zadaniem równie ważnym jest zwiększenie używania Internetu poprzez rozwój e-usług oraz e-gospodarki.

Z kolei cyfryzacja zasobów kultury pozwoli na rozszerzenie tradycyjnych ról instytucji kultury. Zintegrowana informatyzacja, która jest oparta na logicznym i skutecznym obiegu informacji, wprowadzenie zasad zarządzania procesowego, efektywności kosztowej powinny sprzyjać większej sprawności i elastyczności państwa oraz przedsiębiorstw. To wszystko da się przeprowadzić pod warunkiem zwiększenia kompetencji cyfrowych społeczeństwa i zapobieżeniu zjawisku wykluczenia osób starszych, nie używających Internetu;

- położenie nacisku na rozwój kapitału ludzkiego, który zdecydowanie mocniej powinien być powiązany z reformami systemu zdrowia oraz zapewnieniem spójności społecznej - edukacją i transferem absolwentów na rynek pracy. Aktywna polityka prorodzinna oraz polityka migracyjna w zdecydowanie większym stopniu ograniczyłyby zagrożenia związane z niekorzystnymi przemianami demograficznymi. Wzmacnianie kompetencji językowych Polaków, to także ważne zadanie w tym obszarze;

- uwzględnienie wagi bezpieczeństwa Polski poprzez większe zaangażowanie na rzecz bezpieczeństwa energetycznego oraz ochrony środowiska. Potrzebę większej i skutecznej interwencji na rzecz bezpieczeństwa energetycznego podkreślał bardzo mocno także tzw. raport Hausnera. Działania takie powinny uwzględniać wykorzystywanie odnawialnych źródeł energii. 
W obszarze drugim, dotyczącym równoważenia potencjału rozwojowego regionów (dyfuzji), dokument modyfikował dotychczasowy model polaryzacyjno-dyfuzyjny równoważenia rozwoju regionalnego i uzupełnił go modelem terytorialnego równoważenia (dyfuzji). Koncepcja polaryzacyjno-dyfuzyjnej polityki rozwoju regionalnego, opiera się na założeniach, iż należy wspierać silne centra rozwoju, tzw. lokomotywy rozwoju, natomiast obszary otaczające je będą korzystały z dyfuzji (tzw. spill-over) efektów ekonomicznych i społecznych.

Według tej koncepcji, aktywizowanie obszarów o niskim poziomie rozwoju jest marnotrawstwem ograniczonych środków publicznych, a transfery finansowe dla tego typu obszarów powinny jedynie zapewniać dostęp do podstawowych usług publicznych. Dyfuzja ma nastąpić automatycznie na późniejszych etapach rozwoju przez wahadłowe migracje siły roboczej oraz przepływy kapitału. Jednak warunkiem jest tu zapewnienie spójności przestrzennej, w tym komunikacyjnej.

Model ten nie wszędzie sprawdził się w polskich warunkach, także dlatego, że okazało się, iż rozwój peryferii nie zależy tylko od skuteczności w budowaniu własnego potencjału rozwojowego, który jest jednak ograniczony, także poprzez brak polityki spójności i konsekwentnego rozwoju infrastruktury podstawowej, jakim jest na przykład dobry system komunikacji i ponadlokalnego transportu (co w dużej mierze wynika ze specyfiki systemu samorządowego, w szczególności słabości powiatów).

W tej sytuacji dokument zaleca raczej uzupełnienie rozwoju regionalnego o model zrównoważonego rozwoju, gdzie wprowadza się między innymi kategorię redystrybucji dochodów na rzecz obszarów zapóźnionych w rozwoju. Zaleca się także włączanie obszarów peryferyjnych do większej współpracy zagranicznej.

Trzeci obszar strategiczny - efektywności i sprawności państwa poza wymienionymi wcześniej programami rozwoju e-usług i tworzenia zintegrowanej informatyzacji, zwraca uwagę na rolę kapitału społecznego, który odnosi się do takich cech organizacji społeczeństwa, jak zaufanie, normy i powiązania, które mogą zwiększyć sprawność społeczeństwa, ułatwiając skoordynowane działania. Na przykład grupa, której członkowie wykazują, że są godni zaufania i ufają innym będzie w stanie osiągnąc znacznie więcej niż porównywalna grupa, w której brak jest takiego zaufania.

Polscy socjolodzy są zgodni, że szybszy rozwój Polski będzie niemożliwy bez wzrostu kapitału społecznego, co w naszych warunkach oznacza przeciwdziałanie rosnącemu brakowi zaufania w relacjach międzyludzkich, ale również brakowi zaufania do instytucji państwa. W dużej mierze dzieje się tak z powodu rosnącej biurokracji, niestabilnego prawa i korupcji. Niski poziom kapitału społecznego manifestuje się także stosunkowo małą aktywnością społeczną i obywatelską (na przykład słabe uczestnictwo w wyborach), niedostateczną jeszcze pozycją organizacji pozarządowych. 
Długookresowa strategia rozwoju kraju, zaproponowana w omawianym dokumencie, wraz $\mathrm{z}$ instrumentami i celami w nim zawartymi, stanowiła szansę cywilizacyjnego rozwoju Polski. W dużej mierze współgrała $\mathrm{z}$ ocenami i analizą raportu „Konkurencyjna Polska. Jak awansować do światowej ligi gospodarczej”. Cechą charakterystyczną obu tych dokumentów jest wyrażane przekonane, że w warunkach gospodarki rynkowej jest miejsce na istotną rolę państwa w kształtowaniu polityki gospodarczej i społecznej. W szczególności w dziedzinie polityki inwestycyjnej, prowadzonej na rzecz zmian strukturalnych oraz w celu pobudzania przedsiębiorczości i konkurencyjności.

\subsection{Strategia Mateusza Morawieckiego na rzecz Odpowiedzialnego Rozwoju}

W warstwie diagnostycznej wiele analiz i ocen, a także wniosków zawartych w obu zaprezentowanych opracowaniach, tj. w raporcie „Konkurencyjna Polska. Jak awansować do światowej ligi gospodarczej” oraz w dokumencie „Polska 2030. Trzecia fala nowoczesności. Długookresowa Strategia Rozwoju Kraju”, pojawia się w trzecim najbardziej - jak się wydaje - ambitnym dokumencie „Strategii na rzecz Odpowiedzialnego Rozwoju do 2020 roku (z perspektywą do 2030 roku)" autorstwa premiera Mateusza Morawieckiego, została przyjęta przez Radę Ministrów 14 lutego 2017 roku. Obecnie strategia ta jest już realizowana przez polski rząd i wyróżnia się śmiałością w stawianiu celów rozwojowych, kompleksowością analizy i nowatorskim - jak na polskie warunki - podejściem, choć nie jest pozbawiona także dyskusyjnych założeń.

Strategia na rzecz Odpowiedzialnego Rozwoju, realizowana w praktyce, wychodzi bowiem z założenia, że potencjał przyjętego wraz z transformacją modelu rozwoju gospodarczo-społecznego wyczerpał się, a Polska potrzebuje nowego impulsu, by wyrwać się z pułapki średniego rozwoju, zaś intencją twórców nowej polityki gospodarczej jest dokonanie przełomu w podejściu do wielu strategicznych kwestii, które są ważne dla kraju.

„Strategia nie powiela dominującego w okresie transformacyjnym podejścia do programowania polityki rozwojowej państwa, opartego w istotnym stopniu na kopiowaniu i naśladownictwie rozwiązań «importowanych» z zagranicy, a zgodnych z podstawowymi założeniami konsensusu waszyngtońskiego" 1 .

Zespół Narodowej Rady Rozwoju przy Prezydencie RP w opinii o Strategii na rzecz Odpowiedzialnego Rozwoju podkreśla, że „Strategia jest rozwinięciem wcześniejszego «Planu na rzecz Odpowiedzialnego Rozwoju», przy dowarto-

1 Zob. K. Raczkowski, w: Opinia o Strategii na rzecz Odpowiedzialnego Rozwoju (Projekt z dnia 29 lipca 2016 roku skierowany do konsultacji społecznej). 
ściowaniu komponentu społecznego w planowaniu strategicznym rozwoju społeczno-gospodarczego kraju.

O ile we wcześniejszym Planie na rzecz Odpowiedzialnego Rozwoju elementy ze sfery polityki społecznej państwa pełniły funkcję drugoplanową (uzupełniająca) względem elementów polityki stricte gospodarczej, stanowiących wyraźny zręb wyjściowej koncepcji, o tyle w przypadku Strategii na rzecz Odpowiedzialnego Rozwoju komponent społeczny jest już pełnowartościowym filarem strategii" 2 .

Strategia, obecnie realizowana przez rząd polski, zakłada, że rozwój Polski może i powinien odbywać się równocześnie w trzech głównych kierunkach:

1) modernizacyjnym (podniesienie konkurencyjności i innowacyjności gospodarki);

2) dyfuzyjnym (równoważenie potencjału rozwojowego poszczególnych regionów Polski);

3) efektywnościowym (zasadniczego wzrostu efektywności i sprawności funkcjonowania państwa i jego instytucji).

SOR wyznacza pięć obszarów koncentracji działań („filarów rozwoju”):

- tworzenie warunków na rzecz reindustrializacji;

- sprzyjanie rozwojowi innowacyjnych firm (polskie czempiony);

- zrównoważony rozwój społeczno-gospodarczy (z uwzględnieniem wspierania małych i średnich przedsiębiorstw);

- budowanie kapitału dla rozwoju oraz

- ekspansja zagraniczna.

Wyodrębnienie tych pięciu filarów rozwojowych jest konsekwencją krytycznej analizy i diagnozy dotychczasowych założeń polityki gospodarczej i społecznej polskich rządów. Jednak Strategia na rzecz Odpowiedzialnego Rozwoju, która jest podstawą decyzji obecnego rządu, wyróżnia się nową jakością w podejściu, ale i realizacji strategicznych priorytetów dla państwa.

Rzeczą znamienną jest też to, że obecna, nowa filozofia rządu polskiego zdecydowanie większą rolę nadaje instytucjom państwa w wytyczaniu koncepcji i realizacji strategicznych zadań polityki gospodarczej i społecznej. Jest to konsekwencją przekonania o dotychczasowej słabości instytucjonalnej polskiego państwa, ale także zapewne i refleksji wynikających z doświadczeń światowego kryzysu finansowego. Dodatkowych argumentów dostarcza pandemia (koronawirus).

Zgodnie ze Strategią na rzecz Odpowiedzialnego Rozwoju, rząd planuje prowadzić politykę przemysłową wdrażającą tak zwaną inteligentną reindustrializację. Ma to dawać impuls do rozwoju nowych gałęzi przemysłu, opartych na

2 Narodowa Rada Rozwoju, Opinia o Strategii na rzecz Odpowiedzialnego Rozwoju (Projekt z dnia 29 lipca 2016 roku skierowany do konsultacji społecznej). 
technologiach cyfrowych, wymagających dużego zaangażowania nauki i wysoko wykwalifikowanej kadry pracowników. Strategia na rzecz Odpowiedzialnego Rozwoju nawiązuje zatem w pewnym stopniu do postulatów zawartych w obowiązującej Strategii Rozwoju Kraju z 2020 roku, dotyczących wzrostu udziału w PKB przemysłów i usług średnio i wysoko zaawansowanych technologicznie.

Zespół Narodowej Rady Rozwoju przy Prezydencie RP w opinii o Strategii na rzecz Odpowiedzialnego Rozwoju stwierdza, że „stawianie na wzrost globalnej konkurencyjności polskiego przemysłu to prawidłowy cel obrany w Strategii, a efektem podejmowanych działań na rzecz inteligentnej reindustrializacji będzie nasycenie przemysłu wysoko wartościowymi usługami $(\mathrm{B}+\mathrm{R}$, design, information and communications technologies - ICT). Ma to zwiększyć udział innowacyjnych produktów wytwarzanych w przemyśle oraz będzie dźwignią wzrostu produktywności. Poziom zatrudnienia w przemyśle i usługach około przemysłowych ma zostać utrzymany” (zob. Opinia na temat dokumentu „Strategia na rzecz Odpowiedzialnego Rozwoju” z 8 września 2016 roku).

Jak zaznacza profesor Witold Orłowski, „Polska [...] potrzebuje rozwoju opartego silniej na rodzimym kapitale, przede wszystkim dlatego, że to właśnie własne, ekspansywne firmy mogą być zainteresowane rozwojem opartym na innowacjach i wykorzystaniu potencjału intelektualnego". Jak słusznie dodaje profesor Witold Orłowski „wyzwolenie procesów modernizujących gospodarkę przez innowacje to zadanie niełatwe, bo na przeszkodzie stoją nie tylko wewnątrzkrajowe bariery administracyjne, systemowe, świadomościowe, ale także bariery zewnętrzne: dotychczasowy podział pracy, przewagi konkurencyjne firm globalnych (zagranicznych)".

Realizacja ambitnych planów zawartych i już wdrażanych przez obecny rząd byłaby trudna do zrealizowania, gdyby napotkała na barierę dotycząca sfinansowania tych planów. Stąd tak mocno zaznaczona w Strategii na rzecz Odpowiedzialnego Rozwoju konieczność budowania kapitału dla rozwoju. Polska potrzebuje lepszego wykorzystania funduszy unijnych, w szczególności funduszy strukturalnych. Fundusze unijne powinny stanowić endogenny kapitał prorozwojowy.

Ale jednocześnie, wobec potrzeby wzrostu stopy inwestycji, a zarazem ograniczenia zadłużenia zagranicznego, pozyskiwanie kapitału z eksportu polskich towarów i usług jest ważnym elementem programu obecnego rządu. Wzrostowi stopy inwestycji do $25 \%$ PKB (obecnie jest ona najniższa w regionie Europy Środkowo-Wschodniej i wynosi 18\%) powinna między innymi towarzyszyć zmiana funkcjonowania instytucji wspierających i finansujących ekspansję polskich eksporterów.

W Strategii na rzecz Odpowiedzialnego Rozwoju premiera Mateusza Morawieckiego dostrzega się też związek pomiędzy wyrwaniem Polski z rozwoju zależnego i radykalną reformą szkolnictwa wyższego. Edukacja to bowiem pod- 
stawowy mechanizm inwestowania w kapitał ludzki - w kompetencje poszczególnych jednostek.

Cele, jakie zakłada Strategia na rzecz Odpowiedzialnego Rozwoju, odpowiadają w dużym stopniu na potrzeby obecnego etapu rozwoju Polski. Głównym jej zadaniem jest tworzenie warunków do wzrostu dochodów Polaków, a zarazem poprawa spójności w wymiarze społecznym, ekonomicznym i terytorialnym. Ocena efektów realizacji nowej koncepcji rozwoju społeczno-gospodarczego Polski będzie możliwa po kilku latach jej realizacji.

Wydaje się, że trafnie zostały wyznaczone główne założenia gospodarcze i społeczne strategii rozwoju Polski w horyzoncie lat 2020 i 2030. Przeciwnicy obecnego rządu gotowi są stawiać znaki zapytania, w szczególności dotyczy to bardzo wysokiej rangi przewidzianych dla zakresu interwencji publicznej, podejmowanej przez rząd w najbliższych latach. Wyrażane są też zastrzeżenia co do finansowych możliwości państwa do zrealizowania ambitnych zamierzeń rządu.

\section{4. „Nowa Ekonomia Strukturalna” - i jej założenia}

Jednak nie trudno zauważyć, że nowa filozofia społeczno-gospodarcza obecnego rządu polskiego wychodzi również naprzeciw tendencjom w zakresie polityki rozwojowej krajów doganiających kraje wysoko uprzemysłowione. Coraz częściej w takich krajach jak Polska pewnym zainteresowaniem cieszy się tzw. Nowa Ekonomia Strukturalna, stosująca podejście neoklasyczne do badania czynników determinujących strukturę ekonomiczną i jej rozwój. Postuluje ona, że struktura przemysłowa $\mathrm{w}$ ramach gospodarki ma charakter endogeniczny względem struktury jej wyposażenia w zasoby.

Jeden z teoretyków i twórców Nowej Ekonomii Strukturalnej, profesor Justin Yifu Lin, doradca rządu chińskiego w zakresie gospodarki oraz wiceprezydent Banku Światowego w latach 2008-2012 uważa, że Nowa Ekonomia Strukturalna stoi na stanowisku, iż czynnikiem o znaczeniu decydującym dla sukcesu rozwojowego jest państwo, które umożliwia ten rozwój, prowadząc odpowiednią politykę przemysłową.

Polityka taka musi ułatwiać przedsiębiorstwom wchodzenie do branż cechujących się ukrytą przewagą komparatywną na konkurencyjnym rynku poprzez pokonanie problemu uzewnętrzniania wartości przez pierwszego inicjatora oraz koordynowanie wymaganych udoskonaleń twardej i miękkiej infrastruktury. Polityka taka winna mieć na celu przekształcanie branż cechujących się ukrytą przewagą komparatywną w narodowe przewagi konkurencyjne.

Struktura ekonomiczna kraju, jak uważa profesor Justin Yifu Lin, w danym okresie ma charakter endogeniczny względem jego wyposażenia w aktualnie 
dostępne zasoby kapitału, pracy i surowców naturalnych. Kraje znajdujące się na różnych etapach rozwoju różnią się pod względem relatywnego wyposażenia w zasoby.

W kraju rozwijającym się przeważnie mamy do czynienia ze względnym deficytem kapitału, podczas gdy dostępność siły roboczej, a często także zasobów naturalnych, jest relatywnie obfita. W krajach rozwiniętych stosunkowo łatwo o kapitał, przy jednoczesnej relatywnie trudnej dostępności siły roboczej. Co do wyposażenia gospodarki w zasoby, w dowolnym konkretnym okresie ich wielkość jest określona, ale z upływem czasu może się zmieniać.

Nowa Ekonomia Strukturalna traktuje poziom wyposażenia gospodarki w zasoby jako punkt wyjścia dla analizy rozwoju, ponieważ determinują one łączny budżet gospodarki oraz relatywne ceny czynników produkcji w danym okresie, czyli wielkości będące dwoma najważniejszymi parametrami dla analizy ekonomicznej (Ju, Lin i Wang, 2015, s. 244-263).

„Relatywne ceny czynników produkcji stanowią o przewadze komparatywnej danej gospodarki. Na przykład, kraje posiadające stosunkowo bogate zasoby siły roboczej przy jednoczesnym deficycie kapitału miałyby przewagę komparatywną w branżach pracochłonnych, ponieważ ich koszty produkcji będą niższe niż w krajach o relatywnie ubogich zasobach siły roboczej i jej wysokich kosztach. Warunkiem wstępnym osiagnięcia przez dany kraj przewagi komparatywnej jest rozwinięcie w nim takich gałęzi gospodarki, które będą zgodne $\mathrm{z}$ jego przewagami komparatywnymi determinowanymi przez aktualny poziom wyposażenia w zasoby (Porter, 1990).

W krajach rozwiniętych dochód i produktywność pracy są wysokie, ponieważ ich względnie duża zasobność kapitałowa sprawia, że ich branże i technologie mają charakter kapitałochłonny. Jeżeli kraj rozwijający się pragnie dogonić kraje rozwinięte pod względem ich dochodu i struktury przemysłowej, najpierw musi zwiększyć swoje relatywne zasoby kapitału w ramach swojej struktury wyposażenia w zasoby do poziomu krajów rozwiniętych. Celem ostatecznym rozwoju gospodarczego jest zwiększenie dochodów kraju, natomiast celem pośrednim jest rozwijanie branż kapitałochłonnych.

$\mathrm{Z}$ kolei celem w bliskiej perspektywie powinno być szybkie zgromadzenie kapitału, aby móc przekształcić przewagi komparatywne tego kraju w kierunku branż bardziej kapitałochłonnych. Inaczej mówiąc, podniesienie poziomu dochodów danego kraju wymaga podniesienia jego poziomu przemysłowego, do czego $\mathrm{z}$ kolei konieczna jest zmiana struktury wyposażenia w zasoby w takim kraju (Lin i Nowak, 2017).

Trudno nie doszukać się pewnej zbieżności poglądów profesora Justina Yifu Lina z pewnymi założeniami, w Strategii na rzecz Odpowiedzialnego Rozwoju premiera Mateusza Morawieckiego. Obaj dostrzegają sens i zasadność, iż takie kraje jak Polska muszą intensywnie szukać impulsu, który pozwoliłby przestawić 
ich gospodarkę na bardziej innowacyjne tory. Takie szanse stwarza czwarta rewolucja przemysłowa.

Zarówno profesor Justin Yifu Lin, jak i premier Mateusz Morawiecki opowiadają się za koncepcją rozwoju przemysłowego dostosowanego do wymagań współczesności. Polega ona na zdefiniowaniu dziedzin, w których dane państwo może w przewidywalnej przyszłości zbudować swoje przewagi konkurencyjne nad innymi krajami.

Kolejnym krokiem jest stworzenie systemu pozwalającego te możliwości wykorzystać. Ale - jak wspomina Justin Yifu Lin - „nawet jeśli rząd stanie na wysokości zadania i zbuduje efektywny system rozwoju wybranych gałęzi przemysłu, może to nie wystarczyć. Jak podkreśla, trzeba także obniżyć koszty transakcyjne, a więc koszty związane z koordynacją działania przedsiębiorstw, między innymi związane z potrzebą monitoringu rynku, czy przeprowadzania kontroli. To jest możliwe, ale wymaga współpracy przedsiębiorców i rządu (Ju, Lin i Wang, 2015, s. 244-263).

Wbrew temu, co niekiedy sygnalizują przeciwnicy chińskiego ekonomisty Justina Yifu Lina oraz premiera RP Mateusza Morawieckiego, obaj kreśląc pożądany obecnie model rozwojowy dla krajów doganiających kraje bogate i wysoko uprzemysłowione, $z$ jednej strony dostrzegają potrzebę istnienia państwowych centrów decyzyjnych, na rzecz polityki przemysłowej programującej, tzw. inteligentną reindustrializację, czy tworzącej skuteczny system ochrony własności intelektualnej. Ale $\mathrm{z}$ drugiej strony ta niepodważalna rola państwa nie zmienia faktu, że klucza do wzrostu konkurencyjności i przewagi na rynkach należy szukać głównie w podmiotach gospodarczych, finansowych i w samych innowatorach.

Justin Yifu Lin nie jest daleki od prawdy, kiedy w wywiadzie dla gazety Polska The Times stwierdza, że „czwarta rewolucja przemysłowa niesie ze sobą sporo szans dla takich państw, jak Polska. Pojawiają się nowe obszary do rozwoju, których na przykład Niemcy jeszcze nie zdołali zapełnić. Tylko potrzeba czasu. Nie da się od razu wynaleźć nowego lekarstwa, które będzie potrzebne na całym świecie, czy nowego telefonu komórkowego, który stanie się globalnym hitem. Trzeba do tego czasu i pieniędzy na prowadzenie badań" (http://www. polskatimes.pl/artykul/9368600,justin-yifu-lin-polska-powinna-zainwestowac-wkilka-kluczowych-dziedzin-przemyslu,3,id,t,sa.html).

\subsection{Wyzwania zewnętrzne dla Polski}

Należy także zwrócić uwagę, iż strategia premiera Mateusza Morawieckiego i jej implementacja będzie także uzależniona od wyzwań zewnętrznych. Potrzeba przede wszystkim obserwować, w jaki sposób będzie ewoluował projekt euro- 
pejski, obejmujący Unię Europejską, a zwłaszcza - jak zmieniać się będzie strefa euro, i jakie będą tego konsekwencje (De Grauwe, 2009).

Warto przypomnieć, że w drugiej połowie XX wieku, dzięki realizacji idei integracji europejskiej, powstała Unia Europejska i Jednolity Rynek. Rozwiązania te były i są ogromnym sukcesem politycznym i gospodarczym. Dla Polski, ale i dla wielu innych krajów bloku sowieckiego, członkostwo w Unii Europejskiej było kluczowe w procesie politycznej i gospodarczej transformacji.

Nie jest przesadą pogląd, że od utrzymania i rozwoju Unii Europejskiej i Jednolitego Rynku (który jest jej kluczowym, choć nie jedynym integralnym składnikiem) zależy pomyślność gospodarcza poszczególnych państw europejskich, w tym naturalnie i Polski.

$\mathrm{Z}$ całą pewnością jednym z wyzwań dla Polski jest projekt dokończenia unii monetarnej lub, jak potocznie się mówi, stworzenia tak zwanego twardego jądra, a więc dalszego wzmocnienia i zacieśnienia współpracy i integracji w Unii Europejskiej głównie przez grupę państw tak zwanej „starej” Unii. Jeśli okaże się, że kraje forsujące ten projekt będą tworzyć rozwiązania instytucjonalne, które w efekcie wykluczałyby dobrowolny udział w przyszłości innych krajów Unii Europejskiej, byłoby to dla Polski bardzo niekorzystne.

Obecnie, co prawda, z wielu względów Polska słusznie pozostaje poza strefą euro, także dlatego, że kryzys wspólnego obszaru walutowego nie został przezwyciężony, to jednak - jak się wydaje - nie powinna ona na zbyt długo pozostawać w kręgu zewnętrznym wobec państw dalej integrującej się Europy. W globalnym świecie mamy do czynienia z samoograniczającą się suwerennością. I w przypadku Unii Europejskiej Polska musi wyważyć, ile obywatele i ile państwo stracą, godząc się na ograniczenie suwerenności, a ile zyskają, zapewniając sobie korzyści, między innymi poprzez obecność w Jednolitym Rynku i strefie euro.

Pozostaję przy opinii, którą wyrażam od wielu lat, że choć strefa euro nie będzie dla Polski arkadią, i należy mówić także o minusach wspólnej waluty, to jednak w dłuższej perspektywie nie należy przesadzać z samymi korzyściami płynnego kursu walutowego. Cechuje go krótkookresowa nieprzewidywalność i długookresowe nieprzystosowanie. Kurs płynny może być niebezpiecznym narzędziem walki konkurencyjnej. Stwarza bowiem pokusę manipulowania polityką pieniężną, aby doprowadzić do deprecjacji rodzimego pieniądza wobec walut partnerów handlowych (Nowak i Shachmurove, 2012).

Na krótki czas i w określonych warunkach, ta polityka może być skuteczna, natomiast na dłuższy już taka nie musi być. Kurs płynny, ułatwiając dzięki deprecjacji uzyskanie równowagi zewnętrznej, poprzez potanienie eksportu i podrożenie importu, rozgrzesza z góry niekonkurencyjność wiele podmiotów, a nawet sektorów gospodarczych i nie wymusza niezbędnych dostosowań realnych w zakresie innowacyjności produkcji i oferty eksportowej. Tak więc deprecjacja waluty jest 
mimo wszystko paliatywem, nie zaś lekarstwem na niską konkurencyjność gospodarki - raczej znieczula niż leczy. W tym sensie jest ona pomocna i ważna, gdy kraj dokonuje wysiłku dostosowań strukturalnych. Ale może też pozwalać na oddalanie trudnych decyzji dotyczących modernizacji gospodarki. Kurs płynny w warunkach globalizacji gospodarki światowej staje się nieprzewidywalny, zwłaszcza dla małej czy średniej gospodarki otwartej, takiej jak gospodarka polska.

\subsection{Zagrożenia o charakterze globalnym}

Po ostatnim kryzysie finansowym i trwającej długo dekoniunkturze w gospodarce światowej globalizację obciąża się winą za utratę miejsc pracy w krajach wysoko rozwiniętych, przede wszystkim w przemyśle, w wyniku przenoszenia produkcji do krajów o niskich kosztach pracy oraz konkurencję tanich producentów z krajów słabo rozwiniętych, intensywnie rozwijających produkcję przemysłową. Deindustrializacja w krajach wysoko rozwiniętych rodzi zarówno problemy społeczne, jak i ekonomiczne, stąd też postulaty powrotu działalności przemysłowej - reindustrializacji (Ryć, Nowak, 2017).

Choć Polska należy do krajów średnio rozwiniętych, to problem reindustrializacji także jest wyzwaniem. Idzie więc o taką politykę przemysłową, aby ogólnoświatowy proces przebudowy przemysłu i spodziewany, przynajmniej częściowy, powrót produkcji do krajów macierzystych korporacji przemysłowych, nie stanowił zaskoczenia dla polskiej gospodarki i wpływał na pogorszenie jej pozycji konkurencyjnej, głównie na rynku Unii Europejskiej.

Jak dotychczas Polska skorzystała z procesu globalizacji i integracji z gospodarką światową - mimo że utraciła wiele miejsc pracy w przemyśle w pierwszych latach transformacji ustrojowej, zaraz po upadku systemu gospodarki planowej. Jednak z czasem korzyści płynące z integracji gospodarki polskiej z gospodarką światową w ramach Światowej Organizacji Handlu (WTO) oraz Unii Europejskiej były coraz większe, co przekładało się na dynamikę wzrostu gospodarczego.

Dziś, korzystając nadal z dopływu kapitału zagranicznego, przynoszącego wzrost produkcji i eksportu, Polska powinna w większym stopniu polegać na własnej, rodzimej przedsiębiorczości, zwłaszcza w rejonach mniej atrakcyjnych dla zagranicznych inwestorów. Potrzebę nowej aktywnej polityki przemysłowej zakłada wspomniana rządowa Strategia na rzecz Odpowiedzialnego Rozwoju.

Jak stwierdza polski ekonomista Kazimierz Ryć, a trudno się z nim nie zgodzić, to: „w Polsce, tak jak w innych krajach, nie można oczekiwać, że polityka przemysłowa spowoduje wzrost zatrudnienia. W świetle tendencji w gospodarce światowej zatrudnienie w przemyśle spada i będzie raczej spadać, a nowo tworzone miejsca pracy wymagają wysokich kwalifikacji. To właśnie nowe technologie przyczyniają 
się do wzrostu wydajności pracy, tworzą wysoką wartość dodaną, która może być wykorzystana - w wyniku redystrybucji - w sektorze usług, w tym usług publicznych, podnoszących standard życia społeczeństwa, jak zdrowie, oświata, wykształcenie, kultura itp. Tam właśnie tworzone są miejsca pracy, które mogą przenieść wzrost zatrudnienia nie tylko w usługach około przemysłowych, lecz także w usługach z zakresu konsumpcji publicznej" (Ryć, Nowak, 2017).

Tak więc globalizacja i integracja gospodarki światowej nie wykluczają ani też nie czynią bezskuteczną politykę przemysłową państw i regionów. Zmiany w gospodarce w warunkach globalizacji oraz postępująca rewolucja technologii przemysłowej zachęcają, jeśli nie wręcz wymuszają, aktywną politykę przemysłową, niesprzeczną z zasadami integracji ekonomicznej. Niewidzialna ręka rynku musi być naprowadzana na wyrównywanie szans krajów i regionów oraz wykorzystywanie z pożytkiem przemysłu w naszej, zależnej od niego, cywilizacji przemysłowej (Ryć, Nowak, 2017). Strategia na rzecz Odpowiedzialnego Rozwoju premiera Mateusza Morawieckiego jest polską odpowiedzią na współczesne dylematy gospodarki światowej.

\section{Bibliografia}

De Grauwe, P. (2009). Economics of monetary union. Oxford: Oxford University Press.

Dornbusch, R. (2000). Keys to Prosperity: Free Markets Sound Money and a Bit of Luck. Cambridge, Mas.: MIT Press.

http://www.polskatimes.pl/artykul/9368600,justin-yifu-lin-polska-powinna-zainwestowac-wkilka-kluczowych-dziedzin-przemyslu,3,id,t,sa.html

Ju, J., Lin, J.Y. i Wang, Y. (2015). Endowment Structures, Industrial Dynamics, and Economic Growth. Journal of Monetary Economics, 76(C), 244-263.

Lin, J.Y. (2009). Economic Development and Transition: Thought, Strategy, and Viability. Cambridge, UK: Cambridge University Press.

Lin, J.Y. i Nowak, A.Z. (2017). New Structural Economics for less advanced countries. Nowa Ekonomia Strukturalna wobec krajów mniej zaawansowanych. Warszawa: Wydawnictwo Naukowe Wydziału Zarządzania Uniwersytetu Warszawskiego.

Nowak, A.Z. (2013). Współczesny świat w erze turbulencji. W: J. Bogdanienko, W. Piotrowski (red.). Zarządzanie: tradycja i nowoczesność. Warszawa: Wydawnictwo Naukowe Wydziału Zarządzania Uniwersytetu Warszawskiego.

Nowak, A.Z. i Shachmurove, Y. (2012). End of Eurozone? W: Understanding Global Economy - National and Regional Studies. Warszawa: Wydawnictwo Naukowe Wydziału Zarządzania Uniwersytetu Warszawskiego.

Porter, M.E. (1990). The Competitive Advantage of Nations. New York: Free Press.

Raczkowski, K. (2016). Opinia o Strategii na rzecz Odpowiedzialnego Rozwoju (Projekt z dnia 29 lipca 2016 roku skierowany do konsultacji społecznej).

Ravenhill, J. (2005). Global Political Economy. Oxford: Oxford University Press.

Ryć, K. i Nowak A.Z. (2017). Globalizacja a reindustrializacja. W: A.Z. Nowak, K. Ryć, K. (red.). Polityka $w$ regionach $w$ warunkach globalizacji. Warszawa: Wydawnictwo Naukowe Wydziału Zarządzania Uniwersytetu Warszawskiego. 
Rozdział 8

\title{
Nowa Ekonomia Strukturalna z polskiej perspektywy*
}

\begin{abstract}
Streszczenie
W opracowaniu zaprezentowano punkt widzenia związany z decydującymi czynnikami i warunkami mogącymi przesądzić o sukcesie modernizacyjnym Polski. Pokreślono rolę polityki przemysłowej i strukturalnej w nawiązaniu do Nowej Ekonomii Strukturalnej, której autorem jest chiński profesor Uniwersytetu Pekińskiego Justin Yifu Lin oraz jego środowisko naukowe, w tym naukowcy z Wydziału Zarządzania Uniwersytetu Warszawskiego.

Na tle wyzwań dla bardziej innowacyjnej gospodarki, przedstawiono pewne uwarunkowania i problemy występujące na polskiej drodze do absorbcji działań innowacyjnych. Stwierdzono, że budowania potencjału innowacyjnego polskiej gospodarki nie należy sprowadzać tylko do procesów techniczno-ekonomicznych. Są jeszcze społeczne i kulturowe uwarunkowania. $\mathrm{Na}$ przykład kapitał społeczny w dużej mierze także determinuje zdolność gospodarki do tworzenia i absorbcji innowacji.
\end{abstract}

Słowa kluczowe: Nowa Ekonomia Strukturalna, polityka strukturalna, Plan na rzecz Odpowiedzialnego Rozwoju, hiper globalizacja, nowy paradygmat rozwojowy, innowacyjna gospodarka.

\section{New Structural Economics from the Polish Perspective}

\section{Summary}

The article presents the point of view related to the decisive factors and conditions that may determine the success of Poland's modernization. The role of industrial and structural policy is outlined, based on the theory of New Structural Economics, whose author is the

Tekst oparty na publikacji Alojzego Z. Nowaka nt. Polskie dylematy rozwojowe $w$ świetle Nowej Ekonomii Strukturalnej, który został zamieszczony w „Przeglądzie Ustawodawstwa Gospodarczego", 2019, nr 12. Warszawa: PWE. 
Chinese professor Justin Yifu Lin of Beijing University and his scientific environment, including scientists from the Faculty of Management of the University of Warsaw.

Regarding the challenges for a more innovative economy, some conditions and problems occurring on the Polish road to the absorption of innovative activities have been presented. It was found that the building innovative potential of the Polish economy should not be reduced only to technical and economic processes. There are also social and cultural conditions. For example, social capital also largely determines the ability of the economy to create and absorb innovation.

Keywords: New Structural Economics, structural policy, Plan of Responsible Development, hyper globalization, new development paradigm, innovative economy.

\section{Wprowadzenie}

Co może okazać się decydujące dla sukcesu modernizacyjnego Polski? Szansę na ten sukces należy upatrywać przede wszystkim w innowacyjności polskiej gospodarki. Na obecnym etapie rozwoju naszej gospodarki jak najbardziej uzasadnione wydaje się szukanie takich działań i podejmowanie takich decyzji, które połączą wydajny i konkurencyjny system rynkowy z przedsiębiorczym państwem umożliwiającym dokonywanie strukturalnych zmian gospodarczych.

W rozdziale tym, w nawiązaniu do rozdziału poprzedniego, zaprezentowano i rozszerzono punkt widzenia związany z decydującymi czynnikami i warunkami mogącymi przesądzić o sukcesie modernizacyjnym Polski. Podkreśla się rolę polityki przemysłowej i strukturalnej. Na tle wyzwań dla bardziej innowacyjnej gospodarki, przedstawiono pewne uwarunkowania i problemy występujące na polskiej drodze do absorbcji działań innowacyjnych

\subsection{Elementy Nowej Ekonomii Strukturalnej dla Polski}

Dotychczasowa modernizacja w przemyśle oparta w dużej mierze na kopiowaniu importowanych rozwiązań i technologii, daje pośrednie wzmocnienie konkurencyjności polskiej gospodarki. Teraz jednak rozwój gospodarczy powinien dokonywać się raczej poprzez wchodzenie na wyższe poziomy w lańcuchu tworzenia wartości dodanej produktu oraz poprzez szybszej zamianie struktury gospodarki, w której coraz większy udział miałyby sektory o większej produktywności i unikalności. Z tego punktu widzenia pożądana nowa polityka strukturalna staje się realną szansą na zwiększenie innowacyjności polskiej gospodarki. 
Jak wielokrotnie wcześniej stwierdzono, autorem koncepcji teoretycznej, znanej w środowisku naukowym Nowej Ekonomii Strukturalnej, jest profesor Uniwersytetu Pekińskiego, w latach 2008-2012 główny ekonomista i wiceprezes Banku Światowego, Justin Yifu Lin. W swoich badaniach zwraca uwage na bariery rozwojowe występujące $w$ wielu krajach o podobnym do Polski poziomie zaawansowania społeczno-gospodarczego. Wskazuje na pułapki i przeszkody na które natrafiają kraje szybciej rozwijające się na drodze do ugruntowania trwałego wzrostu gospodarczego, a szerzej sprawiedliwszego rozwoju społecznogospodarczego.

Zdaniem profesora Justina Yifu Lina oraz jego współpracowników (Wydział Zarządzania Uniwersytetu Warszawskiego podjął także taką ograniczoną współpracę), dynamiczny rozwój gospodarki wymaga organicznego związku między rynkiem a państwem, związku, który polega na tym, że rynek jest wydajny tylko wtedy, gdy państwo odgrywa ułatwiającą rolę przezwyciężanie nieprawidłowości w jego działaniu. Państwo rozwijające się - bez względu na to, czy jest silne, czy słabe - może w sposób pragmatyczny podejmować i realizować politykę pobudzającą dynamiczny wzrost, nawet pomimo istniejących niedomagań w postaci słabo rozwiniętej infrastruktury i instytucji (Lin, Nowak, 2018).

Justin Yifu Lin nie opowiada się za bardzo znaczącym zwiększeniem zakresu kontroli państwa nad rynkiem czy za pogłębianiem prostego interwencjonizmu. Jednak twierdzi, iż państwo wypełnia między innymi istotną rolę stymulującą, regulacyjną, promującą, a więc także ułatwiającą funkcjonowanie rynku, a przez to staje się pożądanym, a czasami koniecznym warunkiem trwałego rozwoju społeczno-gospodarczego.

Kluczowe rozważania Justina Yifu Lina i jego współpracowników dotyczą rozwoju gospodarczego, który dokonuje się w procesie dynamicznym. Jest to proces ciągłych innowacji technologicznych i modernizacji przemysłu. Takie modernizacje i ulepszenia wymagają kogoś, kto wykona pierwszy ruch. W trakcie tego procesu pojawiają się dwa problemy związane z niedoskonałością rynku.

Pierwszym z nich jest czynnik zewnętrzny, tzn. rząd musi stworzyć zachętę dla pierwszego gracza. Drugim jest koordynacja w celu poprawy funkcjonowania instytucji krajowych oraz wszelkiej infrastruktury, które mają wpływ na koszty transakcji i na prawdopodobieństwo sukcesu pierwszych graczy.

Tak więc, oprócz skutecznego mechanizmu rynkowego potrzebny jest rząd, czy jego instytucje o charakterze strategicznym, odgrywające aktywną rolę w ułatwianiu zmian strukturalnych (Lin, Nowak, 2018).

Te dwa warunki, skuteczny rynek i państwo ułatwiające dokonywania zmian, dają szansę na osiąganie przewag komparatywnych i w dłuższej perspektywie otwierają całą gospodarkę na rynek światowy. Podążanie za przewagami komparatywnymi generuje możliwość uzyskania większych nadwyżek finansowych i tworzy zachęty do wzrostu oszczędności i inwestycji. 
Justin Yifu Lin zwraca również uwagę na jakość klasy politycznej. Dążąc do modernizacji, przywódcy polityczni w wielu krajach przyjęli pewne strategie obejmujące zestaw wytycznych polityki, w tym różnych zaleceń i paradygmatów, które miały gwarantować osiągnięcie sukcesów gospodarczych. Ze względu na złożony charakter modernizacji krajów rozwijających się i doganiających kraje najbardziej uprzemysłowione, a także niejednakowy stopień rozumienia tych procesów u przywódców politycznych, za najbardziej praktyczne rozwiązanie w ramach starań o rozwój kraju uznawali oni podążanie za dominującymi ideami ekonomicznymi i społecznymi. I właśnie dominujące idee ekonomiczne kształtowały nierzadko porządek instytucjonalny i prawny państw rozwijających się (mowa tutaj o założeniach tzw. konsensusu waszyngtońskiego, który zalecał dokonanie prywatyzacji, liberalizacji oraz deregulacji gospodarki oraz drastyczne ograniczenie roli państwa).

Problem polega więc na tym, że w dziedzinie dążenia do modernizacji dominująca myśl społeczna i ekonomiczna opierała się na błędnej percepcji głównych przyczyn i niedomagań krajów rozwijających się i państw o średnim poziomie rozwoju. Wiele strategii ekonomicznych powstało pod wpływem poprzednich generacji ekonomii rozwoju, które wprowadzały przywódców politycznych w błąd i zniekształciły niejedną politykę ekonomiczną w tych krajach. W konsekwencji tego, przywódcom nie tylko nie udało się dotrzymać złożonych obietnic, że ich kraje wejdą na drogę takich samych sukcesów, jakie stały się udziałem krajów rozwiniętych, lecz wręcz ich posunięcia prowadziły do stagnacji, częstych kryzysów, a nawet pociągały za sobą katastrofalne następstwa dla ich gospodarek (Lin, 2009).

Tylko nieliczne kraje zdołały w tym okresie wydobyć się spod wpływu dominującej myśli ekonomicznej i społecznej - przykładem są tygrysy Azji Wschodniej w latach sześćdziesiątych i Chiny w latach osiemdziesiątych XX wieku i obecnie. Przywódcy tych rządów nie ulegali nadmiernym wpływom dominujących wówczas teorii, a ponadto $\mathrm{w}$ okresie transformacji przyjęli podejście pragmatyczne.

To ekonomiczno-społeczne podejście Justina Yifu Lina i zwolenników Nowej Ekonomii Strukturalnej koresponduje obecnie z krytycznym namysłem nad stanem gospodarek wielu rozwiniętych krajów kapitalistycznych oraz szerzej nad stanem gospodarki globalnej.

\subsection{W poszukiwaniu nowego paradygmatu rozwojowego}

Prezes Polskiego Towarzystwa Ekonomicznego profesor Elżbieta Mączyńska uważa, że: „W ekonomii doszło do paru negatywnych zjawisk pod wpływem doktryny neoliberalnej i dominacji nurtu neoklasycznego, który cechuje fundamentalizm rynkowy, czyli że rynek wszystko świetnie rozwiązuje, łącznie 
z etyką. Wobec tego rola państwa powinna być zminimalizowana; jak określił to Ferdinand Lassalle, choć stwierdzenie to błędnie przypisywane jest intelektualnemu ojcu ekonomii i liberalizmu, Adamowi Smithowi: państwo występuje w roli stróża nocnego. Oznacza to, że państwo rezygnuje ze swojej aktywnej roli w kształtowaniu polityki gospodarczej i społecznej. Problem potrzeby zmian w ekonomii nasila się. Globalny kryzys finansowy w 2008 roku wzbudził nawet bunt wśród studentów ekonomii na tle rozmijania się przyswajanej przez nich teorii z praktyką" (Mączyńska, 2019).

Studenci z Uniwersytetu Manchester podczas jednego z protestów mówili nawet coś takiego: „Uczymy się, że gospodarka jest zrównoważona, rynek likwiduje wszelkie nierównowagi, a tymczasem wybucha najpoważniejszy kryzys w okresie powojennym i nikt nam na uczelni tego nie wyjaśnia. Czego właściwie nas uczą? - modeli, wykresów, zależności matematycznych, ale nie wyjaśniają przyczyn tych zjawisk. Jeżeli utożsamiamy rozwój tylko ze wzrostem gospodarczym, to umykają nam na przykład dwa filary: społeczny i ekologiczny. Jakie są tego następstwa? W transformacji ustrojowej w wielu krajach przez prawie trzy dekady dochodziło do zaniedbań społecznych i ekologicznych. Obecnie na świecie nie bez przyczyny pojawiają się takie koncepcje, jak bezwarunkowy dochód podstawowy" (Mączyńska, 2019).

Jak dalece ulega zmianie do niedawna dominujący paradygmat rozwojowy niech świadczy nagroda Nobla z ekonomii w 2019 roku, którą Akademia Szwedzka przyznała trzem osobom. Są to Abhijit Banerjee, Esther Duflo i Michael Kremer. Nagrodzono ich za eksperymentalne podejście do walki z ubóstwem. Cała trójka naukowców zajmuje się ekonomią rozwoju - analizuje, wyjaśnia i wskazuje dlaczego kraje rozwijają się w różnym tempie, dlaczego jedne społeczeństwa są bardziej produktywne od innych, oraz dlaczego w jednych nierówności dochodowe rosną, a w innych maleją.

Podobnie jak Justin Yifu Lin i jego współpracownicy, nobliści z 2019 roku twierdzą, że pomoc finansowa takich instytucji, jak na przykład Bank Światowy, musi być nakierowana na rozwiązywanie konkretnych problemów w krajach rozwijających się, i doganiających państwa najwyżej rozwinięte, ale w sposób starannie dopasowany do kultury, obyczajów i prawa kraju ją przyjmującego.

Akademia Szwedzka zwróciła też uwagę, że „praca noblistów pokazała, w jaki sposób można rozwiązać problem ubóstwa, zadając bardziej precyzyjne pytania dotyczące na przykład edukacji i opieki zdrowotnej”. Ważna jest więc aktywna rola rządów w tych krajach, które powinny identyfikować i mądrze wspierać zindywidualizowane potrzeby społeczne.

Zdaniem laureatów z 2019 roku, w minionych dekadach pomoc finansowa była głównie przekazywana bezpośrednio do rządów, które miały ją jak najlepiej wykorzystać, znając lokalne uwarunkowania. Przedstawili dowody na to, że rządy wielu krajów rozwijających się są często skorumpowane i nie mają 
odpowiedniego zaplecza eksperckiego, co prowadzi do marnotrawienia funduszy, a nawet zwiększenia nierówności dochodowych.

Ale problem nierówność pod względem majątku i dochodów, czy również szans, jakie ludzie dostają już na starcie nie dotyczy tylko krajów rozwijających się oraz tych próbujących dogonić państwa wysoko rozwinięte. Christine Lagarde w swoim pierwszym wystąpieniu po objęciu kierownictwa nad Europejskim Bankiem Centralnym stwierdziła, że kraje strefy euro powinny skupiać się bardziej na wzmacnianiu swoich rynków wewnętrznych, inwestycji w sektorze publicznym i wyrównywaniu nierówności społecznych (polityka inkluzywna), by sprostać wyzwaniom globalnej gospodarki. Wezwała do wzmocnienia europejskiego rynku wewnętrznego poprzez dokończenie tworzenia jednolitego rynku cyfrowego, unii rynków kapitałowych i jednolitego rynku usług, które, jak powiedziała, są „elementami składowymi europejskiej gospodarki przyszłości”, oprócz potrzeby ukończenia unii gospodarczej i walutowej. Mówiła też o „momencie szansy” dla Europy, stwierdzając, że musi ona postawić na innowacje i inwestycje, aby zachować swoją konkurencyjność w dłuższej perspektywie i tym samym odpowiedzieć na wyzwania globalne mające charakter strukturalny. Zatem, jej zdaniem, polityka pieniężna mogłaby osiągnąć swój cel szybciej i przy mniejszej liczbie skutków ubocznych, gdyby wraz z nią inne polityki państw i rządów ją wspierały. Na przykład rządy w strefie euro powinny mieć wspólny interes w utrzymaniu wysokich poziomów inwestycji publicznych, które obecnie są poniżej pożądanego poziomu (Lagarde, 2019).

Dziś trudno więc nie docenić roli państwa w rozwoju społeczno-gospodarczym. Problematykę tę w sposób oryginalny i twórczy podejmuje także profesor Mariana Mazzucato w książce pt. Przedsiębiorcze Państwo. Obalić mit o relacji sektora publicznego i prywatnego (Mazzucato, 2016).

Jak zwraca uwagę w przedmowie do polskiego wydania tej książki, premier Mateusz Morawiecki politycy najbardziej rozwiniętych państw świata są „,zwolennikami leseferyzmu tylko w słowach - w domenie polityki gospodarczej są natomiast zwolennikami aktywizmu i udziału państwa w najważniejszych procesach gospodarczych, $\mathrm{w}$ tym $\mathrm{w}$ polityce przemysłowej i polityce wspierania przedsiębiorczości” (Morawiecki, 2016). Mateusz Morawiecki przekonuje, iż sztuką współczesnej polityki przemysłowej jest optymalne współdziałanie sektorów: publicznego i prywatnego.

Wielką zaletą książki Mariany Mazzucato jest sprawnie przeprowadzony dowód na to, że państwa, które odniosły największy sukces, umiejętnie stymulowały pewne procesy gospodarcze, innowacyjne, także dzięki współpracy instytucji rządowych, sektora publicznego i prywatnego. Dla przykładu Mariana Mazzucato przekonywująco przedstawia niezbite fakty potwierdzające, iż z grantów rządowych skorzystała Dolina Krzemowa, liczne spółki technologiczne (na przykład Apple, iPod), czołowe obecnie spółki z dziedziny nanotechnologii, 
biotechnologii, sektora farmaceutycznego itp. Prywatne spółki wykorzystały po prostu rządowe granty, które pozwoliły dokonać przełomowych odkryć, aby następnie je skomercjalizować z gigantycznym zyskiem.

$\mathrm{Z}$ polskiej perspektywy z diagnoz zawartych w książce Mariany Mazzucato warto wyciągnąć wnioski dotyczące sposobów i charakteru wsparcia oraz inicjacji na rzecz przedsiębiorczości i innowacyjności polskiego przemysłu i polskich firm w oparciu o doświadczenia rozwiniętych państw świata, a więc także do pewnego stopnia o doświadczenia amerykańskie.

Wiele ważnych wskazówek i zaleceń należy wywieść z teorii i sprawdzonych już doświadczeń wynikających z implementacji Nowej Ekonomii Strukturalnej. Polska poszukuje dziś skutecznych narzędzi utrzymania wysokiego wzrostu gospodarczego i zmniejszania luki rozwojowej, przede wszystkim względem krajów Europy Zachodniej. Chce jednocześnie bardziej zrównoważonego rozwoju i społecznej akceptacji dla przeprowadzanych reform.

Do pewnego stopnia polską odpowiedzią na te obecne globalne wyzwania społeczne i gospodarcze jest autorski Plan Odpowiedzialnego Rozwoju premiera Mateusza Morawieckiego, w którym podkreśla się istotność połączenia wydajnego i konkurencyjnego systemu rynkowego z państwem umożliwiającym ułatwianie i wspieranie strukturalnych zmian gospodarczych.

\subsection{Polska droga do innowacji}

Ażeby Polska mogła szybciej zbliżać się w kierunku najbardziej rozwiniętych państw świata istnieje również potrzeba diagnozy uwarunkowań zewnętrznych naszej gospodarki. Polska w sferze gospodarczej jest częścią międzynarodowego ładu, który jest tworzony w warunkach postępującej hiper globalizacji.

Szczególnie w dłuższym okresie kluczem do bardziej stabilnego i zrównoważonego rozwoju społeczno-gospodarczego stają się systematyczne działania na rzecz podniesienia konkurencyjności i produktywności firm, a w konsekwencji i całej gospodarki poprzez zróżnicowane działania proinnowacyjne.

$\mathrm{Z}$ tych nowych tendencji występujących w procesie hiper globalizacji nasz kraj powinien wyciągnąć właściwe wnioski. Dziś polską odpowiedzią na obecne wyzwania są zmiany technologiczne i organizacyjne, służące próbom podniesienia efektywności i konkurencyjności. Ważną rolę ma odegrać nowa polityka przemysłowa i strukturalna rządu.

Premier Mateusz Morawiecki w przedmowie do polskiego wydania wspomnianej wcześniej książki Mariany Mazzucato, mówiąc o roli „przedsiębiorczego państwa” stwierdza także: „Jeśli spojrzymy na narzędzia stosowane przez państwo, które osiągają największy sukces we wspieraniu swoich firm, to zauważmy, że korzystają one przede wszystkim z tradycyjnych prerogatyw państwa w zakre- 
sie polityki gospodarczej. Wśród narzędzi rozpoznamy bowiem dobrze pomyślaną politykę zamówień publicznych, sprawną politykę finansowania grantów na badania i rozwój, efektywny system podatkowy, odpowiedzialną działalność organów regulacyjnych, czy też łatwe w dostępie finansowanie projektów strategicznych przez państwowe instytucje rozwoju".

W obecnym modelu rozwojowym należy uwzględniać zmieniające się uwarunkowania społeczne. Jedynie wzrost inkluzywny i odpowiedzialny społecznie może być - jak to nazywa - „skałą, na której zbudujemy nowoczesną gospodarkę mogącą stawić czoła wyzwaniom XXI wieku". Ten aspekt uwarunkowań społecznych na rzecz strategii innowacyjnej w Polsce, zasługuje na oddzielną analizę.

W publikacji Grzegorza Jędrzejczaka i Henryka Sterniczuka pt. Innowacyjność - polski problem rozwojowy. Doganianie Zachodu w warunkach nieciagtości jej Autorzy uzasadniają, iż Polska musi rzeczywiście uporać się z fazą rozwojową okresu transformacyjnego i uzyskaniem zdolności rozwojowych gospodarki niezbędnych do pokonania historycznie ukształtowanej relacji PKB na mieszkańca Polski stanowiącego około $70 \%$ poziomu PKB państw Europy Zachodniej. W sferze niematerialnej, ów kontekst uwarunkowań społecznych odnoszących się do potencjału innowacyjnego polskiej gospodarki, wydaje się także umyka szerszej refleksji.

Tymczasem, składnik uwarunkowań społecznych jest niezwykle istotnym składnikiem ekonomii politycznej innowacyjności. Jak stwierdzają obaj Autorzy: „Doświadczenie poszczególnych przypadków sukcesu, ale i porażki, pokazuje, że nie ma jednej recepty kulturowej rozwoju, są jednak ograniczenia kulturowe. Społeczeństwa, w którym jednostki czują się związane tradycjonalistycznymi wartościami, a jednocześnie skupione są na wartościach przetrwaniowych, przy braku lub bardzo małej legitymizacji dla samoekspresji są często mało innowacyjne. Innowacja jest bowiem ekspresją inności i aby ją generować ludzie potrzebują czuć się swobodnie w uzewnętrznianiu swoich poglądów, nawet jeśli są one w mniejszości w społeczeństwie, czy w konkretnej grupie w miejscu pracy, oraz gdy nawet ich błędność nie naraża autora na społeczną kpinę i ostracyzm (Jędrzejczak, Sterniczuk, 2020).

Grzegorz Jędrzejczak i Henryk Sterniczuk cytują także Ronalda Ingleharta i Wayne E. Bakera, którzy twierdzą, iż rozwój ekonomiczny jest powiązany z przesunięciem od absolutnych norm i wartości w kierunku wartości, które są w rosnący sposób racjonalistyczne, tolerancyjne, oparte na zaufaniu i partycypacji. W tym sensie Jędrzejczak i Sterniczuk nawiązują także do wartości, które tworzą tzw. kapitał społeczny.

Problem relacji pomiędzy jednostką a zbiorowością jest przedmiotem badań wielu socjologów i politologów. Ich zdaniem, „kapitał społeczny odnosi się tu do takich cech organizacji społeczeństwa, jak zaufanie, normy i powiązania, które 
mogą zwiększyć sprawność społeczeństwa ułatwiając skoordynowane działania: Tak jak i inne postaci kapitału, kapitał społeczny jest produktywny, umożliwia bowiem osiągnięcie pewnych celów, których nie dałoby się osiągnąć, gdyby go zabrakło" (Putnam, Leonardi, Nanetti, 1995).

W Polsce kapitał społeczny, potrzebny także do przejawiania postaw nowatorskich, innowacyjnych jest na niskim poziomie. Dodatkowo definiowanie polityki jako ostrego sporu pomiędzy głównymi ugrupowaniami politycznymi, prowadzi do głębokiego, czasami nieodwracalnego podziału pomiędzy nie tylko jednostkami, ale i grupami społecznymi. Ogranicza to zdolności do tak pożądanego zaufania - konstruktywnego współdziałania członków społeczeństwa, koniecznego do zwiększenia między innymi zdolności innowacyjnych.

\section{Podsumowanie}

Polska poszukuje dziś skutecznych narzędzi utrzymania wysokiego wzrostu gospodarczego i zmniejszania luki rozwojowej, przede wszystkim względem krajów Europy Zachodniej.

W tym względzie warto dostrzec szanse, jakie tworzy przemyślana polityka przemysłowa i strukturalna. Jest też oczywiste, iż nie można wyłącznie ograniczać budowania potencjału innowacyjnego polskiej gospodarki do procesów techniczno-ekonomicznych. Czy nawet, jak najbardziej potrzebnych, a nawet koniecznych decyzji z zakresu polityki przemysłowej, czy strukturalnych decyzji podejmowanych przez państwo, lub podmioty gospodarcze, w ramach pożądanego modelu rozwojowego. Są bowiem jeszcze społeczne i kulturowe uwarunkowania. Kapitał społeczny w dużej mierze także determinuje zdolność gospodarki do tworzenia i absorbcji innowacji.

\section{Bibliografia}

Buera, F.J. i Shin, Y. (2010). Financial Frictions and the Persistence of History: A Quantitative Exploration. Journal of Political Economy, 121, (2), 221-272.

Jędrzejczak, G. i Sterniczuk, H. (2020). Innowacyjność - polski problem rozwojowy. Doganianie Zachodu w warunkach nieciagtości (s. 55). Warszawa: Wydawnictwo Naukowe Wydziału Zarządzania Uniwersytetu Warszawskiego.

Lagarde, Ch. (2019). President of the European Central Bank (ECB) addresses the 29th Frankfurt European Banking Congress in Frankfurt, Germany, Nov. 22, https://www.ecb. europa.eu

Lin, J.Y. i Nowak, A.Z., (2018). Nowa polityka strukturalna $w$ warunkach otwartej gospodarki rynkowej (137-138). Warszawa: Wydawnictwo Naukowe Wydziału Zarządzania Uniwersytetu Warszawskiego. 
Lin, J.Y. (2009). Economic Development and Transition: Thought, Strategy and Viability. Cambridge, UK: Cambridge University Press.

Mazzucato, M. (2016). Przedsiębiorcze państwo. Obalić mit o relacji sektora publicznego i prywatnego (s. 70). Poznań: Wydawnictwo Ekonomiczne Heterodox.

Mączyńska, E. (2019). Wywiad dla Obserwatora Finansowego, 18 listopada.

Morawiecki, M. (2016). Przedmowa. W: Mazzucato, M. Przedsiębiorcze Państwo. Obalić mit o relacji sektora publicznego i prywatnego (s. XXVII, XXXI). Poznań: Wydawnictwo Ekonomiczne Heterodox.

Nowak, A.Z. i Zalega, T. (2019). Makroekonomia (wyd. 2, s. 597-598). Warszawa: Polskie Wydawnictwo Ekonomiczne.

Putnam, R., Leonardi, R. i Nanetti, R.Y. (1995). Demokracja w działaniu: tradycje obywatelskie we wspótczesnych Włoszech (s. 258). Kraków: Społeczny Instytut Wydawniczy Znak; Warszawa: Fundacja im. Stefana Batorego. 


\title{
Rozdział 9 \\ Kontrola kapitału przeciw pułapce średniego dochodu*
}

\begin{abstract}
Streszczenie
Kraje rozwijające się, obecnie znacznie już zaawansowane w rozwoju, do których zalicza się Polska mają wiele niższą produktywność czynników wytwórczych, w tym wydajności pracy. Wśród przyczyn ważne znaczenie ma niekorzystny dla nich podział pracy w światowym łańcuchu tworzenia wartości. Ważną przyczyną takiego stanu w krajach postsocjalistycznych była przyspieszona prywatyzacja, głównie z udziałem kapitału zagranicznego, a także struktura zagranicznych inwestycji bezpośrednich.

W gospodarce narodowej dominują zagraniczne korporacje, które lokowały w tych krajach pracochłonne procesy produkcji, korzystając z taniej siły roboczej. Podrzędną rolę miejscowej produkcji wzmocnił proces globalizacji. Kraje postsocjalistyczne mogą na trwale znaleźć się w pułapce średniego rozwoju, a obecnie funkcjonują w swoistej niższej lidze gospodarki światowej. Poślednia rola miejscowych podwykonawców wynika z tego, że nie partycypują oni we własności kapitałowej firm i tym samym mają mały wpływ na władzę międzynarodowych korporacji. Poprawa ich pozycji wymaga aktywnej polityki państw, w tym również w zakresie kontroli struktury przepływu kapitału w ujęciu brutto.
\end{abstract}

Słowa kluczowe: kontrola kapitału, przewaga komparatywna, transformacja ustrojowa, pułapka średniego dochodu, gospodarcze czempiony.

\section{A Control of Capital Against the Middle Income Trap}

\section{Summary}

Developing countries, which are currently significantly advanced in development, including Poland, have a much lower productivity of production factors, including labor productivity.

\footnotetext{
$\mathrm{Na}$ podstawie artykułu autorstwa prof. Kazimierza Rycia, Kontrola kapitału przeciw putapce średniego dochodu. W: J.Y. Lin, A.Z. Nowak (red.). (2018). Nowa polityka strukturalna w warunkach otwartej gospodarki rynkowej. Warszawa: Wydawnictwo Naukowe Wydziału Zarządzania UW.
} 
The main important fact is the unfavorable division of labor in the global value chain, postsocialist countries experienced accelerated privatization, mainly with foreign capital. It is also important the structure of foreign direct investment.

The national economy is dominated by foreign corporations which locate labor-intensive production processes in these countries, using just cheap labor. The globalization process has reinforced the inferior role of local productions. The post-socialist countries can find themselves permanently in the middle development trap, and currently they are in a kind of lower league of the world economy. The subordinate role of local subcontractors results from the fact that they do not participate in the capital ownership of companies and thus have little influence on the power of multinational corporations. Improving their position requires active state policy, including the control of the structure of capital flows on a gross basis.

Keywords: control of capital, comparative advantage, political transformation, middle income trap, economic champions.

\section{Wprowadzenie}

Polskiej gospodarce grozi spowolnienie tempa wzrostu z powodu wygasania czynników dających jej przewagę komparatywną w stosunku do wysoko rozwiniętych partnerów gospodarczych i handlowych. Może tak się stać ponieważ wystąpią skutki niekorzystnego podziału pracy, który przypadł Polsce w międzynarodowym łańcuchu tworzenia wartości towarów i usług. O korzystnej pozycji zajmowanej w tym łańcuchu przesądza kapitał, który daje władzę w dominujących korporacjach międzynarodowych. Poprawa tej pozycji wymaga bardziej skutecznego zarządzania kapitałem.

Polska, stanowiąca małą gospodarkę otwartą, osiągnęła w ostatnim ćwierćwieczu, po transformacji ustrojowej, wydatny postęp gospodarczy. Wysokie tempo wzrostu gospodarczego ułatwiały znaczne zasoby dobrze wykształconej i taniej siły roboczej, przyuczonej do produkcji w warunkach uprzemysłowienia, w procesie nieefektywnej tzw. industrializacji socjalistycznej. Zasoby ludzkie pozostawały dostępne dla inwestorów, zarówno miejscowych, jak i zagranicznych, w kraju w znacznym stopniu zurbanizowanym. Można dodać, że miało też znaczenie korzystne położenie geograficzne Polski, w bliskim sąsiedztwie Unii Europejskiej.

Transformacja ustrojowa na początku lat 90. ubiegłego wieku przyniosła radykalne zmiany w gospodarce polskiej, nazwane „terapią szokową”. Przyśpieszona prywatyzacja w ramach „terapii szokowej” sprawiła, że podstawowe zakłady produkcyjne z braku kapitału rodzimego, zostały przejęte przez kapitał zagraniczny. Stworzone też zostały atrakcyjne warunki dla zachęty do bezpośrednich inwestycji zagranicznych (BIZ). Inwestorzy zagraniczni wykorzystali tę 
zachętę, to jest przede wszystkim tanią siłę roboczą, przenosząc pracochłonne procesy produkcyjne do Polski.

Prywatyzacja czasem była $\mathrm{w}$ istocie sprzedażą segmentu rynku, a prywatyzowane przedsiębiorstwo wkrótce zostało zamknięte, zaś rynek krajowy na jego miejsce wypełnił zagraniczny producent. Najczęściej jednak zakład przechodził restrukturyzację, a z czasem modernizację i stawał się wykonawcą produkcji zlecanej przez nowego właściciela. W tej fazie rozwoju polskiej gospodarki dawało to jednak wzrost produktywności, wydajności pracy i w efekcie korzyści obu stronom: zagranicznym właścicielom - zarządcom i krajowym wykonawcom. Był to więc offshoring korzystny dla obu stron.

W łańcuchu tworzenia wartości przedsiębiorstwo znajdowało się na dole łańcucha tworzenia wartości opisywanego „krzywą uśmiechu”, w której najwyższą marżę wartości dodanej uzyskują firmy ulokowane na początku i na końcu łańcucha. Bowiem na obu podniesionych jej krańcach tworzą cenę produktu i wartość dodaną właściciele kapitału, twórcy marki producenta, projektanci, organizatorzy łańcucha kooperacji produkcji, zarządzający tym łańcuchem i specjaliści marketingu.

Niżej będą usługi dla biznesu: księgowe. finansowe, prawne, logistyczne i inne, a po środku krzywej, najniżej - działalność fabryczna. Działalność najbardziej profitującą, umieszczoną na krańcach krzywej, nazwę skromnie: zarządzaniem.

Niestety, owo zarządzanie nie jest polską specjalnością w międzynarodowym podziale pracy. O tej uprzywilejowanej lokacie decyduje właśnie własność kapitału i dzięki temu władza, a ta należy do akcjonariuszy i podległych im managerów zarządzających korporacją, nawet jeśli ci ostatni rekrutują się spośród rezydentów. Kapitał - jak wiadomo - nie ma ojczyzny, natomiast akcjonariusze ją mają lub nawet często sami sobie ją wybrali w rajach podatkowych.

Rozbudzona aktywność przedsiębiorcza społeczeństwa w nowych warunkach ustrojowych, a jednocześnie znaczny napływ kapitału, prywatyzacja przez wykup przedsiębiorstw państwowych przez zagranicznych inwestorów oraz nowe inwestycje bezpośrednie z zagranicy sprawiły, że Polska została gwałtownie włączona w proces globalizacji gospodarki światowej, osiagając ewidentne korzyści, jak też, niestety, została narażona na pewne ograniczenia, czy wręcz zagrożenia, które uwidoczniły się z czasem.

Globalizacja, globalne rynki utrwaliły więc, zarówno producentom krajowym, jak i inwestorom zagranicznym inwestującym w Polsce tę samą pozycję - podrzędne miejsce w łańcuchu tworzenia wartości produktów i usług. Były to role: kooperanta, podwykonawcy, czy wykonawcy produktów finalnych, zlecanych przez międzynarodowe korporacje. Nie było to jednak, w ówczesnym stanie polskiej gospodarki, zupełnie niekorzystne.

Bezpośrednie inwestycje zagraniczne przyczyniły się wydatnie do wzrostu zatrudnienia i wydajności pracy, lecz nie były przełomem w zakresie upowszech- 
nienia nowych technologii, ponieważ stanowiły przeniesienie części procesów produkcyjnych. Ten charakter inwestycji dobrze ilustruje ich wydajność mierzoną wartością dodaną według poszczególnych branż, w których te inwestycje były lokowane.

Efekty bezpośrednich inwestycji zagranicznych (FDJ) mierzone udziałem w tworzeniu produktu krajowego brutto w Polsce badała platforma wiedzy „Polityka Insight”. Część tych wyników zawiera tabela 9.1.

Tabela 9.1. Udział FDI w wybranych branżach w nakładach i rezultatach

\begin{tabular}{|l|c|c|}
\hline & $\begin{array}{c}\text { Struktura branżowa napływu } \\
\text { inwestycji zagranicznych (FDJ) }\end{array}$ & $\begin{array}{c}\text { Udział branż we wzroście PKB } \\
\text { dzięki tym inwestycją (FDJ) }\end{array}$ \\
\hline Przetwórstwo przemysłowe & $32 \%$ & $17 \%$ \\
\hline Budownictwo & $4 \%$ & $6 \%$ \\
\hline Handel & $16 \%$ & $19 \%$ \\
\hline Pozostałe usługi & $52 \%$ & $68 \%$ \\
\hline
\end{tabular}

Źródło: Czerniak i Blauth, 2017.

Choć zagraniczne inwestycje przynosiły do Polski nowe technologie, to jednak były one z obszaru produkcji przetwórczej, przynoszącej stosunkowo mały wzrost wartości dodanej w działalności przemysłowej i budowlanej, wyższy natomiast $\mathrm{w}$ handlu, a zwłaszcza $\mathrm{w}$ pozostałych usługach. Natomiast o wiele ważniejszym rezultatem był ich wpływ na rozszerzenie możliwości eksportu, co miało duże znaczenie dla poprawy bilansu płatniczego kraju.

Otwarcie gospodarki na procesy globalizacji przynosiło także nowe doświadczenia organizacyjne $\mathrm{w}$ dziedzinie międzynarodowych relacji gospodarczych i handlowych ${ }^{1}$, a także umożliwiło szeroki dostęp do kapitału i rynków zagranicznych oraz przyczyniło się do wzrostu eksportu. Rosła też wydajność pracy i wynagrodzenia, gospodarka Polski skracała dystans rozwojowy do krajów wyżej rozwiniętych.

Zasadność w tych okolicznościach przyjęcia instytucji wykształconych w Europie przez Polskę podkreśla Dani Rodrik (Rodrik, 2011). Przeprowadzone reformy i dobry stan finansów państwa, pozwoliły również spełnić kryteria przystąpienia Polski do Unii Europejskiej w 2004 roku. Wspólny rynek unijny stał się kolejnym impulsem rozwojowym. Postępował proces konwergencji realnej, wzmacniany dodatkowo przez solidarnościowe fundusze unijne.

1 Dani Rodrik zwraca uwagę na to, że Polska podobnie jak inne kraje Europy przeszła podobną drogę historyczną. Naśladowanie instytucji, które zostały w Europie stworzone mogło być przydatne w warunkach polskich (Rodrik, 2011). 
Kryzys gospodarki światowej z lat 2008-2009 tylko spowolnił tempo wzrostu, lecz nie przerwał procesu konwergencji. Ożywienie gospodarcze, czy wręcz dobra koniunktura w gospodarce światowej, pozwoliły podtrzymać ten proces, lecz - jak się wydaje - nie na długo. Rola podwykonawcy nieuchronnie da o sobie znać. Proces konwergencji realnej ustanie. Kraj może wpaść w pułapkę średniego dochodu. Ten termin, choć powszechnie używany, określający sytuację danego kraju, w przypadku sytuacji polskiej gospodarki nie jest - naszym zdaniem - odpowiedni.

Lepiej tu skorzystać z terminologii sportowej: kraj pozostaje na trwałe graczem niższej ligi gospodarki światowej, z niewielką szansą awansu do ekstraklasy. Może się rozwijać, lecz nie osiągnie poziomu PKB liczonego na 1 mieszkańca, a zatem i dobrobytu obywateli krajów wysoko rozwiniętych. Główną przyczyną jest właśnie ta niższa produktywność pracy, wynikająca z mniej korzystnego miejsca w łańcuchu tworzenia wartości (GWC). Nie jest to dobry podział pracy między równymi partnerami, bo też partnerzy nie są równi. Nie sposób tu stosować zasady korzyści komparatywnych Davida Ricardo, ponieważ gospodarka światowa jest odmienna od tej z przed dwóch wieków. Postulat, by każdy robił to, co potrafi najlepiej i najtaniej, gdy w warunkach stwarzanych przez globalizację mogą robić wszyscy ten sam produkt finalny, wykonując tylko różne czynności w różnych krajach ${ }^{2}$.

\subsection{Pułapka czy druga liga}

Tempo wzrostu gospodarczego w Polsce jest nadal wyższe niż w sąsiadujących krajach wysoko rozwiniętych, a poza okresem pandemii osiaga nawet 4-5\% roczni. Gdy w wielu krajach Unii Europejskiej stopa wzrostu jest o połowę niższa. Może zatem powstać pytanie: skąd ta obawa o przyszłość polskiej gospodarki o ustanie procesu konwergencji realnej? Niepokój wynika z kilku powodów.

Zaawansowanie w rozwoju gospodarczym Polski sprawia, że niebezpieczeństwo pułapki średniego dochodu jest póki co mało prawdopodobne. Poziom PKB w przeliczeniu na jednego mieszkańca według parytetu siły nabywczej stanowi nieco ponad $50 \%$ produktu najbogatszego sąsiada - Niemiec i około 70\% analogicznego poziomu 19 krajów „starej” Unii Europejskiej. Polsce bliżej do krajów rozwiniętych niż większości emerging markets.

2 Na przykład Francuzi lansują modę sukienki, więc organizują produkcję, mieszkańcy Azji Wschodniej, tkają i szyją, a Polacy, prowadzą księgowość, magazynują i transportują. Wszyscy pracują w tym bynajmniej nie najnowocześniejszym sektorze gospodarki, lecz wnoszą różną wartość dodaną, co owocuje różnym wynagrodzeniem i różnym poziomem partycypacji w tworzeniu PKB. 
W przeglądzie literatury światowej na temat pułapki średniego poziomu rozwoju Andrzej Wojtyna stwierdza, że „definicje »pułapki« można podzielić na te o charakterze jakościowo-deskryptywnym oraz na te o charakterze ilościowym. W przypadku tych pierwszych często zwraca się uwagę na trudności w przesuwaniu się krajów na średnim poziomie rozwoju w górę międzynarodowego łańcucha wartości. W tym ujęciu bariery wzrostu mają przede wszystkim charakter mikroekonomiczny w związku z czym ich przezwyciężenie wymaga zastosowania określonych narzędzi polityki przemysłowej” (Wojtyna, 2016, s. 8).

W tego typu pułapce, też w niższej lidze gospodarki światowej może znaleźć się Polska. W tym przypadku tradycyjna polityka przemysłowa, lub szerzej - sektorowa, już nie wystarczy. Powstaje więc pytanie, czy w poszukiwaniu sposobu przeciwdziałania w przypadku takiej postaci pułapki średniego poziomu rozwoju można wykorzystać metodę Nowej Ekonomii Strukturalnej (NES) sformułowanej przez Justina Yifu Lina (Lin i Nowak, 2018).

Samo promowanie sektorów o wyższej wartości dodanej, w tym przypadku już nie przyniesie pożądanych rezultatów, ponieważ poszczególne sektory, w tym również tego typu, w kraju już istnieją, lecz miejsce krajowych producentów w tych sektorach jest niekorzystne, podrzędne. Wynika to ze struktury własności i funkcji zarządzania łańcuchem tworzenia wartości w poszczególnych korporacjach. Chodzi więc o wykorzystanie instrumentów zarządzania przepływem kapitału, aby uniknąć niebezpieczeństw pozostania na trwałe w „drugiej lidze” krajów zaawansowanych w rozwoju, skazanych na niższą produktywność pracy i tym samym niższą marżę wartości dodanej w przeliczeniu na zatrudnionego.

Ten stan to niekorzystny rezultat $\mathrm{w}$ istocie pożądanej, lecz pośpiesznej prywatyzacji i również pożądanych, choć nie zawsze spełniających oczekiwania gospodarzy, zagranicznych inwestycji bezpośrednich (BIZ).

Pomyślny rozwój gospodarczy partnerów handlowych Polski, zwłaszcza krajów Unii Europejskiej, sprzyja wzrostowi gospodarczemu również krajów pozostających w owej niższej lidze gospodarki europejskiej. Krzywa produktywności w kształcie „krzywej uśmiechu” może się nawet wygładzać w kierunku prostej.

Po pierwsze, dlatego, że zwiększa się udział w tworzeniu PKB wyżej wycenianych usług $\mathrm{w}$ porównaniu $\mathrm{z}$ działalnością fabryczną, w tym zwłaszcza usług dla biznesu. Mogą również wzrastać i rzeczywiście wzrastają wynagrodzenia w działalności produkcyjnej oraz w usługach, zarówno w następstwie wzrostu poziomu kwalifikacji pracowników, lepszego wyposażenia technicznego miejsc pracy, jak też w następstwie sytuacji na rynku pracy. Wyczerpują się bowiem zasoby taniej siły roboczej, w tym jednak przypadku pojawia się także zagrożenie.

Po drugie, w polskiej gospodarce dużą rolę odgrywają małe i średnie przedsiębiorstwa, w tym również przedsiębiorstwa rodzinne. Przedsiębiorstwa te są zarządzane oczywiście przez miejscowych przedsiębiorców, co powinno sprzy- 
jać wyższej produktywności, wynikającej z pozycji własności i władzy. Jednak skala prowadzonej działalności w ramach tych przedsiębiorstw jest niewielka, a więc w rezultacie również i produktywność jest niższa niż w przypadku firm wchodzących w skład wielkich korporacji.

Rozwój takich przedsiębiorstw musi jednak sprostać konkurencji na rynku zdominowanym przez wielkie korporacje. Jeśli tego typu przedsiębiorstwa nie zostaną zdominowane przez konkurencję, czy też przez nią wykupione, to w rezultacie ich działalności będzie następować również wygładzenie krzywej produktywności.

Z kolei wszystkie inne małe i średnie przedsiębiorstwa wraz z wyczerpywaniem się zasobów siły roboczej będą między sobą konkurować o pozyskanie pracowników, co spowoduje również wzrost kosztów pracy, wymuszając zmiany organizacji pracy i inwestycje na rzecz wzrostu wydajności pracy także w tym sektorze. Takie działania w efekcie łącznym przyczynią się też do wzrostu wartości dodanej. Niestety taki bieg zdarzeń może okazać się nazbyt optymistyczny.

Wzrost wynagrodzeń to utrata ważnego elementu przewagi konkurencyjnej. To przecież niższe koszty pracy sprzyjały przenoszeniu do Polski pracochłonnych procesów produkcji oraz szeregu usług, w tym również biznesowych. Międzynarodowe korporacje mogą ten rodzaj działalności przenosić do krajów tańszych rąk do pracy. Tak więc outsourcing, który służył polskiej gospodarce w poprzednim stanie niskich płac i bezrobocia, w początkach budowy gospodarki rynkowej, teraz może stać się zagrożeniem, jeśli pozostawi po sobie pogorszenie pozycji przetargowej pracowników, czy wręcz bezrobocie.

Po trzecie, dla krajów rozwijających się oraz dla krajów znacznie zaawansowanych w rozwoju, goszczących jednak w niższej lidze gospodarki światowej pojawia się niestety nowe zagrożenie, wynikające z nowej rewolucji przemysłowej nazywanej Przemysłem Generacji 4.0. Choć postęp techniczny, związany $\mathrm{z}$ tą generacją, jest przyjmowany $\mathrm{z}$ entuzjazmem, to jednak kraje, które nie nadążają za przesuwającą się $\mathrm{w}$ górę granicę wysokich technologii mogą wiele stracić. Wynika to nie tylko z następstw w postaci zaniku konwergencji realnej, lecz może nawet spowodować dywergencję, pogłębienie różnić w poziomie rozwoju (Ryć, 2017).

Offshoring procesów produkcji z krajów o wysokich kosztach pracy może zamienić się w reshoring, ponieważ w wyniku cyfryzacji produkcji, inteligentnych fabryk oszczędzających ludzką pracę i tym samym jej koszty. Powrót przetwórstwa przemysłowego do krajów macierzystych międzynarodowych korporacji spowoduje powstanie poważnych problemów dla krajów słabiej rozwiniętych (Götz, 2018).

Jest więc wystarczająco dużo powodów, aby kraje mniej zaawansowane w rozwoju podjęły wysiłki na rzecz opuszczenia owej drugiej ligi. 


\subsection{Zarządzanie strukturą przepływu kapitału dla pożądanych efektów w skali mikroekonomicznej}

Panuje powszechna opinia, że drogą do osiągnięcia wysokiej produktywności są innowacje i przedsiębiorczość. Innowacje tworzy kapitał ludzki i społeczny, na który składają się instytucje sprzyjające innowacyjności. Tworzenie kapitału ludzkiego wymaga nakładów finansowych na badania naukowe i kształcenie kadr. Niezbędne jest też publiczne wspieranie inkubacji przedsiębiorczości i aktywna w tej dziedzinie rola państwa.

Protegowanie rozwoju gospodarczego przez państwo sprawdziło się w historii w przypadku krajów dziś wysoko rozwiniętych. Również zdało egzamin w wielu gospodarkach dawniej ubogich, zwłaszcza w Azji Wschodniej i Południowo-Wschodniej, obecnie wysoko rozwiniętych lub znacznie zaawansowanych w rozwoju.

Tego typu protekcjonizm jest wykluczony w przypadku Polski - członka Unii Europejskiej - która po transformacji ustrojowej wkroczyła z sukcesem na drogę liberalnej gospodarki rynkowej, choć jest narażona na przedstawione wcześniej zagrożenie pozostania w statusie kraju podwykonawcy.

Postulat postawienia na innowacje, ich tworzenie, formowanie kapitału ludzkiego i społecznego jest oczywisty. Nakłady kapitałowe na ten cel są uzasadnione. Nie ma jednak gwarancji, że dzięki nim wyrosną w kraju potęgi technologiczne generujące wysoką wartość dodaną. Powodem tego są niesprzyjające warunki „hodowli” takich championów, jakie stwarza wolny rynek, a tym bardziej wspólny rynek europejski. Można co najwyżej liczyć na odosobnione przypadki, ponieważ swobodny przepływ kapitału i wolny rynek temu nie sprzyjają.

O tym swoją opinię, która odnosi się do typu emerging market, ale także do Polski, najbardziej dobitnie wyraził Joseph E. Stiglitz: „Liberalizacja handlu oznaczała, że zagraniczne firmy mogły «wyżynać w pień» raczkujące miejscowe branże, tłamsząc rozwój przedsiębiorczych talentów. Gdy kapitał przepływał swobodnie, przepływ siły roboczej był ograniczony - z wyjątkiem najbardziej utalentowanych jednostek, $\mathrm{z}$ których wiele znajdowało dobre zatrudnienie na globalnym rynku pracy" (Stiglitz, 2010, s. 258).

Te ostre słowa noblisty odnoszą się również do doli wielu inicjatyw i karier wybitnych jednostek w Polsce. Nie są natomiast usprawiedliwieniem dla polskich lamentów nad odpływem zysków za granicę od międzynarodowych korporacji, które zainwestowały w Polsce. Do tego mają prawo, więc powinniśmy pozostać im życzliwi za to, co uczynili tworząc miejsca pracy i za to, co pozostawiają w Polsce w postaci wynagrodzeń pracowniczych $-\mathrm{z}$ reguły wyższych od tych rodzimych w małych i średnich przedsiębiorstwach oraz zapłaconych u nas podatków. 
Nie oznacza to bynajmniej rezygnacji z osłony i ze wspierania rodzimych konkurentów również za pomocą środków kapitałowych, w tym przez bardziej skuteczne zarządzanie strukturą przepływu kapitału. A więc nie chodzi o zmianę reguł gry, lecz o skuteczniejszą grę o wejście przez rodzimy kapitał na pozycję zarządzania w coraz większej części liczących się producentów i świadczeniodawców usług. Wypracowanie metod i narzędzi operowania kapitałem, w tym kształtowaniem struktury kapitału w skali mikroekonomicznej, wspierającym politykę przemysłową, wydaje się zadaniem możliwym w założeniach Nowej Ekonomii Strukturalnej.

W tym miejscu można wskazać kilka kierunków oddziaływania za pomocą środków kapitałowych.

1. Na pierwszym miejscu należy postawić to co prawie wszyscy badacze uważają za istotne, a mianowicie na nakłady finansowe na wzrost kapitału ludzkiego i społecznego. Chodzi o to by zdolnych ludzi kształcić, a wykształconych nie tracić. Badania finansować, lecz ich wyników, które mogą być zaczynem innowacji nie eksportować w surowej postaci. Nie jest to więc zadanie prostego powiększania środków na ten cel, lecz o ich przemyślaną strukturę zabezpieczającą uzyskanie pożytku z zainwestowanego kapitału. Struktura angażowanych środków winna nie tylko maksymalizować wzrost, lecz także minimalizować ubytek i straty tego kapitału.

2. Wydaje się, że należy ostrożnie podchodzić do państwowej „hodowli” championów. To co było możliwe w Azji Wschodniej nie jest do powtórzenia w Europie Środkowej i we wspólnym rynku. Dla przykładu, w Polsce postawienie na elektromobilność w przemyśle samochodów osobowych, bez rodzimych innowacji, nie ma wielkich szans na wyjście poza wykonawstwo i montaż. Technologicznie zaawansowane komponenty będą zakupywane za granicą nawet wtedy, gdy zagraniczni producenci zechcą je wytwarzać w Polsce. To oni właśnie znajdują się w korzystnej pozycji, wnikającej z ich własności i władzy. Nie znaczy to, że podobnych prób nie należy całkowicie wykluczyć, lecz nie można wzorem reguł „starej” Ekonomii Strukturalnej, która między innymi dopuszczała produkcję antyimportową - na nich budować korzystnej pozycji w łańcuchu tworzenia wartości (Lin i Nowak, 2018)3.

3. Kontrola struktury dopływu i odpływu kapitału: wspieranie outsourcingu do Polski przedsięwzięć innowacyjnych zgłaszających popyt na pracę wykwalifikowaną, dobrze wynagradzaną oraz na usługi dla biznesu. $\mathrm{Z}$ rezerwą natomiast trzeba się odnosić do przenoszenia prostej produkcji, jeśli ona nie ułatwia rozwiązywania na przykład lokalnych problemów rynku pracy.

\footnotetext{
Polskie przedsiębiorstwo, które z sukcesem wytwarzało autobusy z napędem elektrycznym, również z sukcesem je eksportowało, zostało wystawione na sprzedaż i zapewne trafi w ręce zagranicznych inwestorów.
} 
4. Udomowienie zagranicznego kapitału przez tworzenie korzystnych warunków dla wprowadzania przez nie nowych technologii, reinwestowania zysków. Wprawdzie obecnie nie można liczyć na współczesnych Wedli, Moteli, czy Bliklich, zagranicznych przedsiębiorców i inwestorów, którzy w Polsce osiedli i od pokoleń prowadzili tu swój biznes. Zapewne za przyczyną choćby większej mobilności społecznej trwała rezydencja zagranicznych współwłaścicieli czy właścicieli jest mniej prawdopodobna.

5. Możliwy jest wykup przez rodzimy kapitał niepubliczny w całości lub też udziałów w zagranicznych przedsiębiorstwach działających w kraju. Nie chodzi tu o repolonizację, czyli wykup przez spółki państwowe, lecz przede wszystkim o rodzimy sektor prywatny wraz z jego umocnieniem na rynku kapitałowym.

6. Pogłębienie usług finansowych nie tylko dla małych i średnich przedsiębiorstw oraz początkujących producentów, lecz również dla ambitnych przedsięwzięć kapitałowych polskich producentów w kraju i za granicą.

7. Celowy offshoring - Polska dotychczas korzystała i nadal korzysta z przenoszenia do nas produkcji zagranicznych firm. Dziś obawiamy się ich ucieczki do miejsc o tańszej sile roboczej. Jednak stosunkowo mały jest jeszcze offshoring polskich firm do krajów o niższych kosztach produkcji. Teraz i w przyszłości należy na większą skalę korzystać z metody offshoringu i przenosić mniej wydajną produkcję poza granice naszego kraju. Oczywiście pod warunkiem, że nie grozi to wzrostem bezrobocia. Tego typu działania polskich przedsiębiorców należy mocniej wspierać.

\section{Podsumowanie}

Proces dochodzenia do korzystnej pozycji w międzynarodowym łańcuchu tworzenia wartości, przy pomocy aktywnej polityki kontroli przepływu kapitału nie jest bynajmniej pewny, ani tym bardziej krótki. Wysiłki w tej dziedzinie należy podejmować, ponieważ zostawianie kraju w owej niższej lidze gospodarki światowej nie tylko nie satysfakcjonuje społeczeństwa, lecz także jest niebezpieczne. Grozi bowiem wpadnięciem w autentyczną pułapkę średniego poziomu rozwoju.

\section{Bibliografia}

Czerniak, A. i Blauth, K. (2017). Co przyniosty inwestycje zagraniczne. Warszawa: Polityka Insight.

Götz M. (2018). Przemysł czwartej generacji (przemysł 4.0) a międzynarodowa współpraca gospodarcza. Ekonomista, (4), 385-403. 
Lin, J.Y. i Nowak, A.Z. (2018). New structural economics for less advanced countries. Warszawa: Wydawnictwo Naukowe Wydziału Zarządzania Uniwersytetu Warszawskiego. Rodrik, D. (2011). Jedna ekonomia wiele recept. Warszawa: Krytyka Polityczna.

Ryć, K. (2018). The expiring real convergence proces under conditions of the common market - how to countries. W: J.Y. Lin, A.Z. Nowak (red.). New structural economics for less advanced countries (s. 69-79). Warszawa: Wydawnictwo Naukowe Wydziału Zarządzania Uniwersytetu Warszawskiego.

Stiglitz, J.E. (2010). Freefall. Warszawa: Polskie Towarzystwo Ekonomiczne.

Wojtyna, A. (2016). Standardowe i niestandardowe działania antykryzysowe. Gospodarka Narodowa, (6), 5-22. 
Rozdział 10

\title{
Profil ryzyko - dochód funduszy inwestycyjnych małych i średnich spółek*
}

\begin{abstract}
Streszczenie
Celem rozdziału jest analiza efektywności i ryzyka funduszy inwestycyjnych inwestujących w akcje małych i średnich spółek na polskim rynku kapitałowym. W artykule poddano weryfikacji hipotezę zakładającą, zgodnie z obserwowanymi na rynkach anomaliami (to jest efekt zapomnianej spółki, efekt kapitalizacji), że w przypadku funduszy inwestycyjnych stosujących strategie inwestowania w akcje małych i średnich spółek, z powodu mniejszej płynności oraz większej asymetrii informacyjnej, pojawi się tak zwana premia w postaci ponadprzeciętnej stopy zwrotu przy jednocześnie większej zmienności stóp zwrotu w relacji do tzw. uniwersalnych funduszy akcyjnych.

Przeprowadzone badania wskazują na występowanie niewielkiej nadwyżkowej stopy zwrotu w grupie funduszy inwestycyjnych małych i średnich spółek przy jednocześnie relatywnie niższym - w relacji do funduszy akcji uniwersalnych - poziomie ryzyka całkowitego (mierzonego odchyleniem standardowym stóp zwrotu) oraz ryzyka rynkowego (mierzonego współczynnikiem beta).
\end{abstract}

Słowa kluczowe: efekt małych i średnich spółek, ryzyko funduszy inwestycyjnych, efektywność rynku.

\section{The Risk - Profit analysis of small-cap mutual funds}

\section{Summary}

The aim of the chapter is to analyze the effectiveness and risks of investment funds investing in shares of small and medium-sized companies on the Polish capital market. Was verified the hypothesis according to observed market anomalies (ie. the small-size firm effect, the effect of capitalization). In the case of investment funds that use strategies to invest in shares

\footnotetext{
Współautorstwo profesor. ndzw. dr hab. Teresa Czerwińska, Katedra Systemów Finansowych Gospodarki, Wydział Zarządzania, Uniwersytet Warszawski. Artykuł pojawił się w cyklicznej publikacji Rynek Kapitatowy, 2014, Wydawnictwo Naukowe Wydziału Zarządzania UW.
} 
of small and medium-sized companies, due to the lower liquidity and greater information asymmetry, the rate of return of these funds should be characterized by greater volatility in relation to the universal equity funds.

Keywords: small-size firm effect, investment risk, market efficiency, market anomalies.

\section{Wprowadzenie}

Badania w zakresie oceny efektywności i ryzyka funduszy inwestycyjnych koncentrują się w zasadzie w dwóch obszarach: (1) ocena umiejętności zarządzających w zakresie konstrukcji portfela (selekcji instrumentów, komponowania jego struktury itd.); (2) ocena umiejętności zarządzających w zakresie doboru momentu zawarcia transakcji z uwzględnieniem trendów rynkowych. Zarówno w jednym, jak i drugim przypadku istotne znaczenie mają tak zwane niedoskonałości rynku oraz asymetria informacji.

Po sformułowaniu przez Eugene F. Famę fundamentalnej dla rynku kapitałowego hipotezy efektywności (Efficiency Market Hypothesis) (Fama, 1970, s. 373-417; 1991, s. 1575-1617), toczy się szeroka dyskusja w tym zakresie, wielu badaczy i praktyków wskazuje na istnienie tak zwanej anomalii dotyczących efektów cenowych na rynku kapitałowym, to jest na przykład: efekty kalendarzowe, efekty związane z wielkością spółki itd. (zob. szerzej charakterystykę anomalii rynkowych w: Czekaj, Woś i Żarnowski, 2001; French, 1980; Harris, 1986; Haugen i Lakonishok, 1988; Keim, 1983; Lakonishok i Smidt, 1988; Lakonishok i Maberly, 1990).

Nierówność informacyjna stron kontraktu jest immanentną cecha rynku (zob. Ackerlof, 1970, s. 488-500; Commission moves to enhance...), lecz jej natężenie na rynku kapitałowym zależy w znacznym stopniu od jakości raportowania przez spółki zarówno danych finansowych, jak i pozafinansowych (aspekty społeczne, środowiskowe, ładu korporacyjnego - Environment Social Governance). Skutki asymetrii informacyjnej są obserwowalne po obu stronach uczestników rynku kapitałowego zarówno wśród inwestorów i zarządzających portfelem, jak i wśród emitentów. Mając na uwadze nieefektywności rynku kapitałowego, rozwinął się cały nurt wypracowywania strategii inwestycyjnych, mających na celu ich wykorzystanie do osiągania ponadprzeciętnej stopy zwrotu.

Wśród wykorzystywanych do konstrukcji strategii inwestycyjnych nieefektywności rynku, przedmiotem badań jest tak zwany efekt małych spółek (small-size firm effect), polegający na występowaniu dodatkowej stopy zwrotu w przypadku akcji spółek o niskiej kapitalizacji (zob. badania: Davis, 2001; Barry i Brown, 1984, s. 283-294; Kester, 1990; Gorman, 2003, s. 287-300; Banz, 1981). Występowanie tej nadwyżkowej stopy zwrotu często łączone jest z niższą płynnością 
walorów małych spółek na rynkach giełdowych (tak zwana premia za płynność) oraz silniejszym efektem asymetrii informacji niż w przypadku spółek dużych. Jest to związane z: (1) szerszym zakresem upublicznianych informacji przez duże spółki - na przykład w zakresie upubliczniania danych pozafinansowych (na terenie UE taki obowiązek informacyjny dotyczy tylko przedsiębiorstw zatrudniających ponad 500 osób oraz wykazujących sumę bilansową powyżej 20 mln euro (lub obrót netto powyżej $40 \mathrm{mln}$ euro) ${ }^{1}$ ); (2) większymi możliwościami zarówno w wymiarze finansowym, jak i organizacyjnym, w zakresie komunikowania się z otoczeniem w przypadku spółek dużych.

Jednocześnie, w literaturze przedmiotu są podejmowane problemy związane ze stosowaniem strategii inwestycyjnych w oparciu o selekcję do portfela małych i średnich spółek (zob.: Chan, Louis, Karceski i Lakonishok, 2000, s. 23-36; Horowitz, Loughran i Savin, 2000, s. 143-153; Reinganum, 1983, s. 89-104; Reinganum, 1983, s. 29-36), tj.: niewielka wartość ponadprzeciętnej stopy zwrotu (lub jej brak) po uwzględnieniu kosztów transakcyjnych oraz trudności z wykorzystaniem w strategiach inwestycyjnych na wysoko rozwiniętych rynkach kapitałowych (słabo zauważalny), a także współwystępowanie z efektami kalendarzowymi, to jest na przykład efekt stycznia.

Celem rozdziału jest analiza efektywności i ryzyka funduszy inwestycyjnych inwestujących w akcje małych i średnich spółek na polskim rynku kapitałowym. W opracowaniu poddano weryfikacji hipotezę zakładającą zgodnie z obserwowanymi na rynkach anomaliami (to jest efekt zapomnianej spółki, efekt kapitalizacji), że w przypadku funduszy inwestycyjnych stosujących strategie inwestowania w akcje małych i średnich spółek, z powodu mniejszej płynności oraz większej asymetrii informacyjnej stopy zwrotu tych funduszy zawierają pewną premię (są ponadprzeciętne) oraz cechują większą zmiennością w relacji do tak zwanych uniwersalnych funduszy akcyjnych.

\subsection{Metodologia badań}

Badaniu poddano dwie grupy akcyjnych funduszy inwestycyjnych lokujących kapitał na polskim rynku kapitałowym: (1) czternaście funduszy inwestycyjnych inwestujących w akcje małych i średnich spółek oraz (2) dziewiętnaście funduszy

\footnotetext{
W ramach nowelizacji dyrektyw UE dotyczących rachunkowości (78/660/EWG i 83/349/EWG) duże przedsiębiorstwa mają obowiązek sporządzać informację uzupełniającą roczne sprawozdanie finansowe o informacje dotyczące: polityki i wyników postępowania, a także wynikającego z tego ryzyka przedsiębiorstwa związanego z kwestiami: społecznymi, środowiskowymi, zatrudnienia, poszanowania praw człowieka, przeciwdziałania korupcji, a także praktyk w kwestii różnorodności w organach zarządzających i nadzorczych spółek. Wymóg ten będzie wdrażany na zasadzie: comply or explain. Zob.: European Commission proposes..., 2013.
} 
inwestycyjnych akcyjnych uniwersalnych (w tym cztery fundusze inwestujące w akcje dużych spólek). Analiza efektywności i ryzyka funduszy inwestycyjnych została przeprowadzona dla notowań dziennych jednostek uczestnictwa w okresie od 25 marca 2009 roku do 28 kwietnia 2014 roku (1258 obserwacji) w ujęciu zarówno całościowym, jak i dla poszczególnych lat. Za stopę zwrotu wolną od ryzyka przyjęto WIBOR 3-miesięczny, a stopę zwrotu z portfela rynkowego odzwierciedlała stopa zwrotu z WIG w analizowanym okresie².

Na pierwszym etapie analizie poddano własności statystyczne szeregu dziennych stóp zwrotu $\left(r i_{d z}\right.$.) obydwu badanych grup funduszy inwestycyjnych oszacowanych zgodnie ze wzorem:

$$
r_{i d z}=\ln \left(\frac{J U t}{J U_{t-1}}\right)
$$

gdzie:

$J U t$ - wartość jednostki uczestnictwa w okresie $t$.

Następnie ocenie poddano ryzyko wybranych funduszy inwestycyjnych z wykorzystaniem: (1) miar zmienności stóp zwrotu (mierzone odchyleniem standardowym $\sigma_{r}(1.2)$ ) oraz (2) wrażliwości stóp zwrotu na zmiany zachodzące na rynku (współczynnik beta $\beta_{i}$ (1.3)) (Jajuga, 2007, s. 39-40), oszacowane zgodnie ze wzorami3:

$$
\begin{aligned}
& \sigma_{r}=\sqrt{\frac{1}{n} \sum_{i=1}^{n}\left(r_{i}-\bar{r}\right)}, \\
& \beta_{i}=\frac{\operatorname{Cov}_{i, m}}{\sigma_{m}^{2}}=\rho_{i, m} \frac{\sigma_{i}}{\sigma_{m}},
\end{aligned}
$$

gdzie:

$\bar{r}$ - średnia arytmetyczna stopa zwrotu,

$\operatorname{Cov}_{i, m}$ - kowariancja stóp zwrotu z portfela $i$-tego funduszu inwestycyjnego oraz portfela rynkowego (reprezentowanego przez indeks giełdowy),

$\rho_{i, m}$ - współczynnik korelacji stóp zwrotu z portfela $i$-tego funduszu inwestycyjnego oraz portfela rynkowego (reprezentowanego przez indeks giełdowy).

2 Dane zostały zgromadzone i opracowane przez uczestników zajęć projektowych pt. Fundusze inwestycyjne i emerytalne realizowanych na Wydziale Zarządzania Uniwersytetu Warszawskiego: K. Boruc, T. Grygier, A. Parypa, K. Deoniziak, P. Gadecki, M. Martyniak.

3 Miary te są szeroko znane i opisywane w literaturze przedmiotu, to jest w: Haugen, 1996; Elton i Gruber, 1998; Reilly i Brown, 2001; Francis, 2000; Jajuga i Jajuga, 2009; Tarczyński, Witkowska i Kompa, 2013. 
Wybrane miary ryzyka funduszy inwestycyjnych należy traktować jako wzajemnie uzupełniające się, odchylenie standardowe wskazuje bowiem na poziom dyspersji stóp zwrotu z portfela danego funduszu inwestycyjnego, co można traktować w kategoriach ryzyka nieuzyskania założonej stopy zwrotu. Natomiast wywodzący się z modelu Sharpe'a współczynnik beta, wyznaczany z wykorzystaniem MNK, pozwala na ocenę zarówno stopnia, jak i kierunku wrażliwości stopy zwrotu z portfela $i$-tego funduszu inwestycyjnego na zmianę koniunktury na rynku. Stąd dokonując oceny ryzyka inwestycyjnego w wykorzystaniem współczynnika beta, należy brać pod uwagę skład portfela odwzorowującego portfel rynkowy.

Najczęściej przyjmuje się, że jest to wybrany indeks giełdowy odzwierciedlający szeroki portfel rynkowy lub indeks skonstruowany w sposób odzwierciedlający spektrum inwestycyjne dla danego podmiotu $\mathrm{z}$ uwzględnieniem pewnych ograniczeń w polityce inwestycyjnej, na przykład dla funduszy emerytalnych. Współczynnik beta pozwala na ocenę ryzyka danego funduszu względem tak zwanego rynku, co umożliwia jego pozycjonowanie oraz ocenę ryzyka rynkowego niedywersyfikowalnego. Istotna jest analiza zmian współczynnika beta w czasie, wówczas można wyciągać wiążące wnioski co do poziomu ryzyka danego funduszu inwestycyjnego. Wartość współczynnika beta zależy od szerokiego spektrum zmiennych.

Do oceny efektywności zarządzanych portfeli przez poszczególne fundusze inwestycyjne $\mathrm{w}$ ujęciu względnym wykorzystano szeroko stosowane $\mathrm{w}$ analizie portfelowej wskaźniki: Sharpe'a (S), Treynora (Tr) i Jensena (tak zwana alfa Jensena $\alpha_{J}$ ). Mając na uwadze, że w teorii ekonomii efektywność odzwierciedla relację uzyskanych efektów do ponoszonych nakładów, w konstrukcji tych wskaźników za nakład przyjmuje się ponoszone przez fundusze inwestycyjne ryzyko: mierzone odchyleniem standardowym ( $\sigma_{p}$ (ryzyko całkowite) lub współczynnikiem beta ( $\beta_{p}$ (ryzyko rynkowe). Wskaźniki: Sharpe'a, Treynora i Jensena wyprowadzane są $\mathrm{w}$ oparciu o powszechnie znany w literaturze przedmiotu model CAPM ${ }^{4}$. Wskaźniki oszacowano zgodnie ze wzorami:

$$
\begin{gathered}
S=\frac{r_{p}-r_{f}}{\sigma_{p}} . \\
T_{r}=\frac{r_{p}-r_{f}}{\beta_{p}} . \\
\alpha_{J}=r_{p}-\left(r_{f}+\beta_{p}\left(r_{m}-r_{f}\right)\right)+\varepsilon_{t} .
\end{gathered}
$$

4 Model opracowany przez W. Sharpe'a, J. Lintnera oraz J. Mossina, opublikowany w: Sharpe, 1964; Lintner, 1965; Mossin, 1966. 
Nie podejmując się szczególowej charakterystyki (wad, zalet, ograniczeń aplikacji) ${ }^{5}$ przedstawionych wskaźników, warto zaznaczyć, że:

- ich zawartość informacyjna, w pewnym uproszczeniu, wskazuje nie tylko na osiągniętą przez zarządzających premię względem ponoszonego ryzyka, lecz także umożliwia wyciąganie wniosków w sposób pośredni, co do dywersyfikacji portfela, na co wskazują różnice w rankingach tworzonych według wskaźników: Sharpe'a (bierze pod uwagę ryzyko całkowite portfela), Treynora (bierze pod uwagę ryzyko rynkowe portfela);

- wskaźniki: Sharpe'a, Treynora mają duże znaczenie dla inwestorów, bowiem (1) są proste w interpretacji - im wyższy wskaźnik, tym wyższa wartość uzyskiwanej premii na jednostkę ponoszonego ryzyka, a tym samym wyższa efektywność analizowanego funduszu; (2) umożliwiają bezpośrednie rangowanie funduszy inwestycyjnych (alfa Jensena $\alpha_{J}$ jest obliczana w ujęciu bezwzględnym) oraz odniesienie uzyskiwanych wyników do portfela rynkowego;

- wartość alfy Jensena $\alpha_{J}$ pozwala na wnioskowanie w zakresie umiejętności zarządzających portfelem inwestycji, informuje bowiem o spreadzie między uzyskaną stopą zwrotu z portfela danego funduszu a przeciętną stopą zwrotu wyznaczoną na podstawie modelu CAPM.

\subsection{Wyniki badań}

Przede wszystkim analizie poddano parametry rozkładu stóp zwrotu uzyskanych przez badane fundusze inwestycyjnej (tabela 10.1). Zarówno w jednej, jak i w drugiej grupie analizowanych funduszy średnie dzienne stopy zwrotu w analizowanym okresie były dodatnie, co odzwierciedlało ogólną dobrą koniunkturę na giełdach nie tylko w Polsce. Rozkład stóp zwrotu analizowanych funduszy wykazywał cechy rozkładu o asymetrii lewostronnej. Oznacza to, że funkcja gęstości prawdopodobieństwa (dla rozkładów ciągłych) po lewej stronie maksimum maleje wolniej niż po prawej, natomiast w rozkładzie stóp zwrotu analizowanych funduszy inwestycyjnych średnia stopa zwrotu przyjmuje wartości niższe od mediany.

Jednocześnie rozkład stóp zwrotu analizowanych funduszy cechował się lepkokurtycznością, co jest typowe dla tego typu rozkładów. Najwyższe średnie dzienne stopy zwrotu w analizowanym okresie osiagały $w$ grupie funduszy akcji małych i średnich spółek: Aviva Investors Nowych Spółek, KBC Subfundusz

5 Zob. szeroką dyskusję dotyczącą wskaźników Sharpe’a, Treynora i Jensena w: Haugen, 1996; Elton i Gruber, 1998; Reilly i Brown, 2001; Francis, 2000; Luenberger, 2003; Jajuga i Jajuga, 2009. 
Akcji Małych i Średnich Spółek, Aviva Investors Małych Spółek oraz w grupie funduszy akcyjnych uniwersalnych: Aviva Investors Polskich Akcji, LM Parasol FIO Subfundusz, UniKorona Akcje, Noble Fund Akcji, KBC Subfundusz AKCYJNY, Subfundusz Credit Agricole Akcyjny FIO.

Średnie dzienne stopy zwrotu w grupie funduszy akcji małych i średnich spółek były nieznacznie wyższe w relacji do grupy funduszy akcyjnych uniwersalnych (co potwierdzają też badania: Salamaga 2009a; 2009b; Witkowska, 2009). Jednocześnie, odchylenie standardowe stóp zwrotu dziennych w przypadku grupy funduszy akcji małych i średnich spółek było nieznacznie niższe w relacji do odchylenia standardowego stóp dziennych funduszy akcji uniwersalnych. Jest to sytuacja nietypowa, ponieważ w teorii inwestycji zakłada się, że wyższej oczekiwanej stopie zwrotu towarzyszy wyższe ryzyko.

Odniesienie uzyskiwanych przez fundusze inwestycyjnych stóp zwrotu do ponoszonego ryzyka całkowitego (mierzonego odchyleniem standardowym dziennych stóp zwrotu) pozwala na sporządzenie profili ryzyko-dochód badanych funduszy (rysunek 10.1).

Zaprezentowane zależności ryzyko-dochód analizowanych dwóch grup funduszy inwestycyjnych należy rozpatrywać:

- w relacji do pewnego benchmarku, jakim jest tak zwany portfel rynkowy - zdecydowana większość funduszy w obydwu analizowanych grupach cechowała się niższym ryzykiem przy jednocześnie niższej dziennej stopie zwrotu;

- w porównaniu między grupami analizowanych funduszy - większość funduszy akcji uniwersalnych cechowała się niższą stopą zwrotu przy wyższym ryzyku całkowitym (mierzonym odchyleniem standardowym stóp zwrotu dziennych) w porównaniu z funduszami inwestującymi w akcje małych i średnich spółek. 


\begin{tabular}{|c|c|c|c|c|c|c|c|c|c|c|c|c|c|c|c|c|c|c|c|c|}
\hline 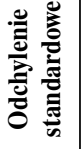 & & 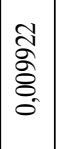 & $\begin{array}{l}\frac{1}{\hat{n}} \\
\frac{0}{0} \\
0\end{array}$ & $\mid \begin{array}{l}0 \\
0 \\
0 \\
0 \\
0 \\
0\end{array}$ & $\begin{array}{l}\stackrel{0}{0} \\
\stackrel{0}{0} \\
0 \\
0 \\
0\end{array}$ & 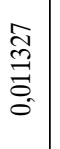 & 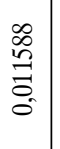 & $\begin{array}{l}\text { o } \\
\text { o } \\
\stackrel{0}{0} \\
0 \\
0\end{array}$ & 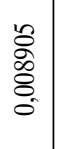 & 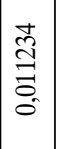 & 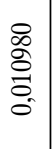 & $\begin{array}{l}\stackrel{0}{2} \\
\stackrel{0}{\Xi} \\
\stackrel{0}{0}\end{array}$ & 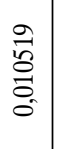 & $\begin{array}{l}\underset{8}{J} \\
\stackrel{8}{8} \\
8 \\
0\end{array}$ & 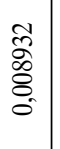 & $\begin{array}{l}\stackrel{J}{\Xi} \\
\stackrel{\Xi}{\Xi} \\
\stackrel{\Xi}{0}\end{array}$ & 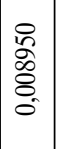 & $\begin{array}{l}\frac{\infty}{0} \\
\stackrel{0}{\vec{\sigma}} \\
0\end{array}$ & 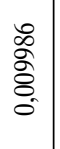 & 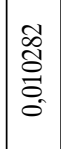 \\
\hline 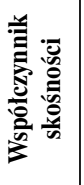 & & $\begin{array}{l}\frac{2}{2} \\
\frac{7}{q} \\
\hat{i}\end{array}$ & $\begin{array}{l}\mathbb{t} \\
0 \\
0 \\
0 \\
0\end{array}$ & $\begin{array}{l}\overline{0} \\
\hat{n} \\
0 \\
1\end{array} \mid$ & 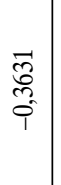 & 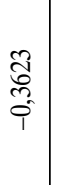 & $\begin{array}{l}\overrightarrow{0} \\
\stackrel{0}{0} \\
\hat{i}\end{array}$ & $\begin{array}{l}\widetilde{3} \\
\widetilde{3} \\
\hat{i}\end{array}$ & $\begin{array}{l}\infty \\
\infty \\
n \\
i \\
i \\
1\end{array}$ & 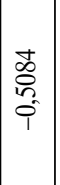 & 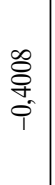 & $\begin{array}{l}\text { ले } \\
\text { ले } \\
\text { î }\end{array}$ & $\begin{array}{l}\stackrel{\partial}{\infty} \\
\hat{m} \\
\hat{i}\end{array}$ & 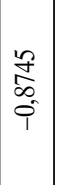 & $\begin{array}{l}\infty \\
\tilde{n} \\
\hat{n} \\
\hat{1}\end{array}$ & 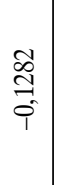 & 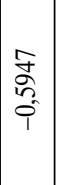 & 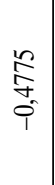 & $\begin{array}{l}\stackrel{P}{2} \\
\stackrel{4}{4} \\
i \\
i \\
1\end{array}$ & $\frac{\stackrel{R}{6}}{\stackrel{0}{i}}$ \\
\hline 胥 & & 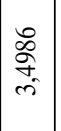 & $\underset{m}{\stackrel{\vec{m}}{\exists}}$ & $\begin{array}{l}\hat{n} \\
\tilde{n} \\
n\end{array}$ & 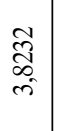 & 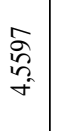 & $\begin{array}{l}\widehat{\infty} \\
\stackrel{\infty}{\infty}\end{array}$ & 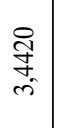 & 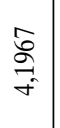 & $\begin{array}{l}\vec{\nabla} \\
\infty \\
\infty \\
\dot{r}\end{array}$ & $\begin{array}{l}\overrightarrow{\bar{\tau}} \\
\underset{\sim}{\sim}\end{array}$ & $\begin{array}{l}\vec{\infty} \\
\stackrel{\sim}{a} \\
\vec{i}\end{array}$ & $\begin{array}{l}\stackrel{2}{6} \\
\text { r. } \\
\text { r. }\end{array}$ & $\frac{\overrightarrow{0}}{\frac{1}{m}}$ & $\stackrel{\curvearrowright}{\check{\sigma}}$ & $\begin{array}{l}\tilde{R} \\
\hat{\sigma} \\
\sigma^{2}\end{array}$ & 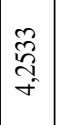 & 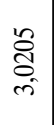 & $\begin{array}{l}2 \\
0 \\
0 \\
m \\
m\end{array}$ & $\underset{\text { in }}{\stackrel{\infty}{二}}$ \\
\hline & & $\begin{array}{l}\infty \\
0 \\
0 \\
0 \\
0\end{array}$ & $\begin{array}{l}\hat{8} \\
8 \\
0 \\
0\end{array}$ & $\begin{array}{l}\text { to } \\
\stackrel{0}{0} \\
0^{\circ}\end{array}$ & $\begin{array}{l}0 \\
8 \\
8 \\
0 \\
0\end{array}$ & 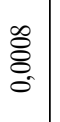 & $\begin{array}{l}5 \\
8 \\
0 \\
0\end{array}$ & $\begin{array}{l}\stackrel{0}{8} \\
\stackrel{8}{0} \\
0^{\prime}\end{array}$ & 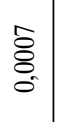 & $\begin{array}{l}8 \\
8 \\
0 \\
0\end{array}$ & 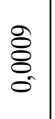 & 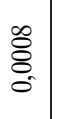 & $\begin{array}{l}\mathscr{8} \\
\tilde{\delta} \\
\delta^{\circ}\end{array}$ & $\begin{array}{l}5 \\
8 \\
8 \\
0\end{array}$ & $\begin{array}{l}\text { d } \\
8 \\
0 \\
0\end{array}$ & $\begin{array}{l}\text { 芯 } \\
8 \\
0\end{array}$ & $\begin{array}{l}\overline{8} \\
\bar{o} \\
\delta\end{array}$ & 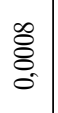 & $\begin{array}{l}0 \\
8 \\
8 \\
0\end{array}$ & 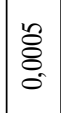 \\
\hline 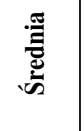 & 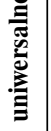 & 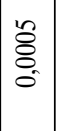 & $\begin{array}{c}0 \\
\delta \\
0 \\
0\end{array}$ & $\vec{\delta}$ & $\begin{array}{l}8 \\
8 \\
0 \\
0\end{array}$ & 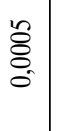 & $\begin{array}{l}\mathbb{0} \\
0 \\
0 \\
0\end{array}$ & $\begin{array}{l}2 \\
8 \\
8 \\
0 \\
0\end{array}$ & $\begin{array}{l}\text { 苂 } \\
8 \\
0 \\
0\end{array}$ & $\begin{array}{c}0 \\
\delta \\
0\end{array}$ & 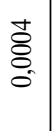 & $\begin{array}{l}\text { d } \\
8 \\
0 \\
0\end{array}$ & $\begin{array}{l}\text { 苂 } \\
0 \\
0 \\
0\end{array}$ & $\begin{array}{l}\overrightarrow{8} \\
8 \\
0\end{array}$ & $\stackrel{8}{8}$ & $\begin{array}{l}\text { 苂 } \\
\vdots \\
0 \\
0\end{array}$ & $\begin{array}{l}\text { ț } \\
\vdots \\
0 \\
0\end{array}$ & $\begin{array}{l}\stackrel{2}{8} \\
8 \\
0 \\
0\end{array}$ & 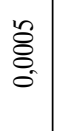 & §ิ \\
\hline$\sum^{\stackrel{x}{E}}$ & \begin{tabular}{l}
$\frac{3}{0}$ \\
J \\
\multirow{2}{*}{} \\
2
\end{tabular} & 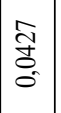 & $\begin{array}{l}\text { 苦 } \\
\text { 品 } \\
0\end{array}$ & $\begin{array}{l}\vec{\partial} \\
\overrightarrow{0} \\
0\end{array}$ & $\begin{array}{l}0 \\
\stackrel{0}{0} \\
0 \\
0\end{array}$ & $\underset{⿱}{\Delta}$ & $\begin{array}{l}8 \\
0 \\
0 \\
0\end{array}$ & $\begin{array}{l}0 \\
0 \\
0 \\
0 \\
0\end{array}$ & $\begin{array}{l}\text { वे } \\
\text { ô. } \\
0 \\
0\end{array}$ & 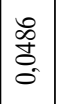 & $\begin{array}{l}\stackrel{?}{2} \\
\dot{s} \\
0 \\
0\end{array}$ & $\begin{array}{l}\text { के } \\
\text { वे } \\
0\end{array}$ & $\begin{array}{l}2 \\
2 \\
0 \\
0 \\
0\end{array}$ & $\begin{array}{l}\infty \\
\mathscr{0} \\
\delta \\
0 \\
0\end{array}$ & $\begin{array}{l}\mathbb{N} \\
\stackrel{0}{0} \\
0\end{array}$ & $\begin{array}{l}\overrightarrow{\widetilde{D}} \\
0 \\
0\end{array}$ & $\underset{\delta}{\overrightarrow{0}}$ & $\begin{array}{l}\hat{y} \\
\stackrel{y}{0} \\
0\end{array}$ & 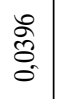 & $\begin{array}{l}\frac{7}{5} \\
\stackrel{0}{0} \\
0\end{array}$ \\
\hline 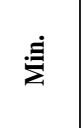 & & $\begin{array}{l}2 \\
2 \\
2 \\
0 \\
0\end{array}$ & $\begin{array}{l}\text { f } \\
\stackrel{0}{0} \\
\stackrel{0}{1}\end{array}$ & $\begin{array}{l}\hat{2} \\
\hat{s} \\
\vdots \\
i\end{array}$ & 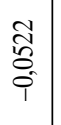 & $\begin{array}{l}\hat{n} \\
\hat{o} \\
\vdots \\
i\end{array}$ & $\begin{array}{l}\stackrel{+}{0} \\
0 \\
0 \\
i\end{array}$ & \begin{tabular}{l}
8 \\
8 \\
0 \\
0 \\
\hdashline \\
1
\end{tabular} & $\begin{array}{l}\vec{\sim} \\
\tilde{Z} \\
0 \\
i\end{array}$ & 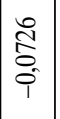 & $\begin{array}{l}0 \\
\text { ò } \\
0 \\
0 \\
0\end{array}$ & 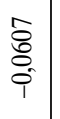 & 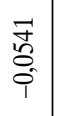 & 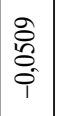 & 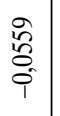 & $\begin{array}{l}\vec{\Xi} \\
0 \\
0 \\
i\end{array}$ & 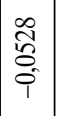 & 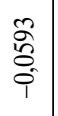 & $\begin{array}{l}\text { त्र } \\
\text { o } \\
\text { î }\end{array}$ & $\begin{array}{l}\stackrel{2}{\hat{s}} \\
\stackrel{5}{1}\end{array}$ \\
\hline 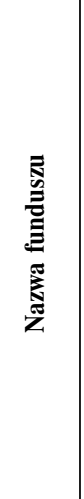 & & 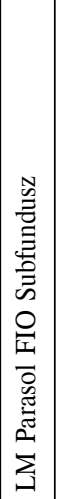 & 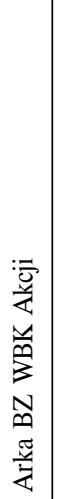 & 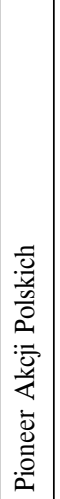 & 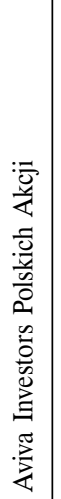 & 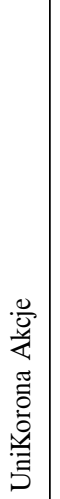 & 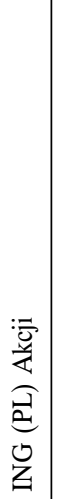 & 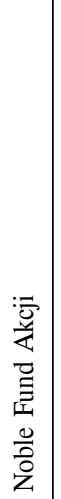 & $\begin{array}{l}\frac{0}{1} \\
1 \\
: \frac{\bar{y}}{y} \\
\frac{y}{2} \\
0 \\
0 \\
\frac{a}{2}\end{array}$ & 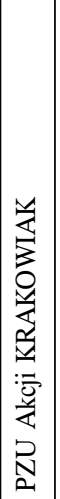 & 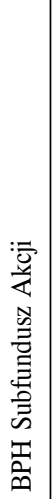 & 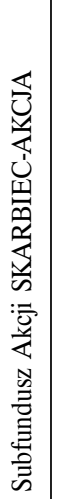 & 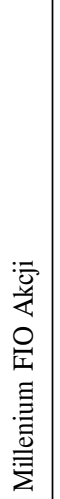 & 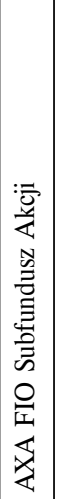 & 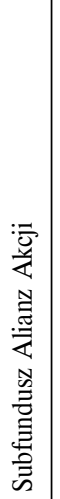 & 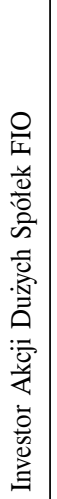 & 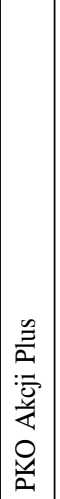 & 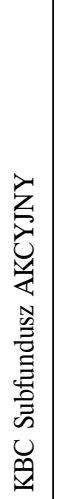 & 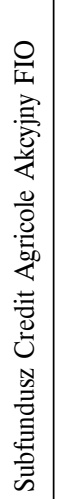 & 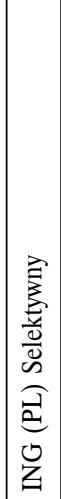 \\
\hline$\dot{\text { I }}$ & & $\dot{-}$ & i & $\dot{r}$ & $\dot{+}$ & in & 0 & $\therefore$ & $\infty$ & $\sigma^{\circ}$ & $\stackrel{\circ}{\circ}$ & $\dot{\exists}$ & $\stackrel{\bigcup}{ }$ & $\dot{\sim}$ & \pm & 10 & $\stackrel{\bullet}{\bullet}$ & 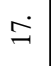 & $\stackrel{\infty}{\cong}$ & $\stackrel{0}{-1}$ \\
\hline
\end{tabular}




\begin{tabular}{|c|c|c|c|c|c|c|c|c|c|c|c|c|c|c|c|}
\hline 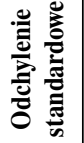 & & $\begin{array}{l}1 \\
\infty \\
0 \\
0 \\
0\end{array}$ & 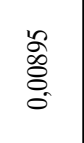 & $\begin{array}{l}+ \\
\infty \\
o \\
0 \\
0\end{array}$ & \begin{tabular}{|c|}
$\frac{0}{0}$ \\
0 \\
8 \\
0 \\
0
\end{tabular} & $\begin{array}{l}\text { Iै } \\
8 \\
8 \\
0\end{array}$ & 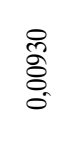 & $\begin{array}{l}\hat{\infty} \\
\text { oे } \\
0 \\
0\end{array}$ & $\begin{array}{l}\mathbb{1} \\
0 \\
0 \\
0 \\
0\end{array}$ & $\begin{array}{l}\vec{\sigma} \\
\stackrel{0}{0} \\
0 \\
0\end{array}$ & $\begin{array}{l}\vec{\Xi} \\
8 \\
8 \\
0\end{array}$ & $\begin{array}{l}8 \\
\circ \\
8 \\
0 \\
0\end{array}$ & 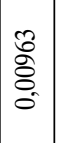 & $\begin{array}{l}0 \\
: \\
0 \\
0 \\
0 \\
0\end{array}$ & $\begin{array}{l}\stackrel{8}{0} \\
\text { \&े } \\
0 \\
0\end{array}$ \\
\hline 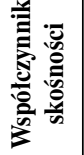 & & 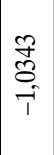 & $\underset{i}{\stackrel{\mathcal{F}}{\sigma}}$ & 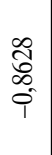 & $\begin{array}{l}\hat{\partial} \\
\text { مे } \\
\hat{i}\end{array}$ & $\begin{array}{l}\text { సे } \\
\text { क्. } \\
\text { î }\end{array}$ & 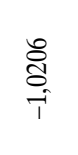 & $\underset{i}{\stackrel{m}{7}}$ & $\begin{array}{l}\infty \\
\stackrel{2}{\Im} \\
\stackrel{i}{1}\end{array}$ & $\begin{array}{l}\overrightarrow{0} \\
\stackrel{\overbrace{}}{7}\end{array}$ & $\begin{array}{l}\text { कo } \\
\infty \\
\infty \\
0 \\
0\end{array}$ & $\begin{array}{l}8 \\
\stackrel{0}{0} \\
\stackrel{i}{i}\end{array}$ & 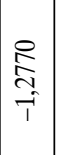 & 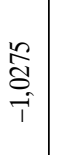 & 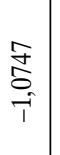 \\
\hline 氖 & & $\begin{array}{l}\tilde{\sigma} \\
\text { ૂू }\end{array}$ & 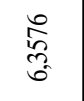 & $\begin{array}{l}\text { वे } \\
\text { o. } \\
\text { in }\end{array}$ & $\begin{array}{c}\infty \\
\infty \\
i n \\
i n \\
i n\end{array}$ & $\begin{array}{l}\text { Fे } \\
\text { ò }\end{array}$ & $\begin{array}{l}\frac{8}{6} \\
\text { in }\end{array}$ & 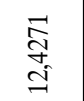 & 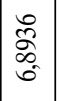 & 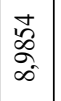 & $\underset{\widehat{d}}{\stackrel{0}{0}}$ & 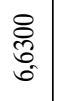 & 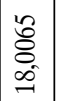 & $\begin{array}{l}\vec{g} \\
\stackrel{g}{\sigma} \\
\stackrel{\sigma}{r}\end{array}$ & $\begin{array}{l}\text { 莳 } \\
\stackrel{2}{二}\end{array}$ \\
\hline 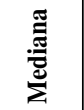 & & $\begin{array}{l}\stackrel{8}{8} \\
0 \\
0\end{array}$ & $\begin{array}{l}0 \\
8 \\
8 \\
0\end{array}$ & $\begin{array}{l}\overline{8} \\
\overline{8}\end{array}$ & 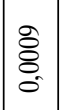 & $\stackrel{\widetilde{a}}{\tilde{8}}$ & $\stackrel{\circ}{\circ}$ & $\begin{array}{l}0 \\
\stackrel{8}{0} \\
0 \\
0\end{array}$ & $\begin{array}{l}\bar{\Xi} \\
\overline{8} \\
0\end{array}$ & 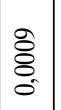 & 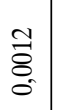 & 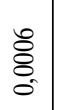 & 今̊ & $\begin{array}{l}\circ \\
\stackrel{\circ}{8} \\
\stackrel{0}{\circ}\end{array}$ & $\begin{array}{l}\circ \\
\stackrel{0}{8} \\
0 \\
0\end{array}$ \\
\hline 莺 & 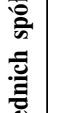 & 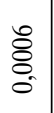 & $\begin{array}{l}\stackrel{2}{o} \\
8 \\
0 \\
0\end{array}$ & $\begin{array}{l}\hat{8} \\
8 \\
0\end{array}$ & $\begin{array}{l}2 \\
\delta \\
0 \\
0 \\
0\end{array}$ & 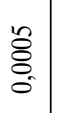 & छे & 芯 & $\begin{array}{l}0 \\
8 \\
8 \\
0 \\
0\end{array}$ & 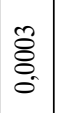 & 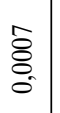 & $\begin{array}{l}\tilde{\delta} \\
\delta \\
0 \\
0\end{array}$ & ồ & 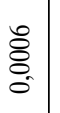 & 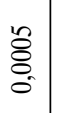 \\
\hline$\sum_{\Sigma}^{\frac{\pi}{z}}$ & 焉 & 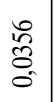 & $\begin{array}{l}2 \\
\text { oิ } \\
0 \\
0\end{array}$ & \begin{tabular}{l}
8 \\
\multirow{8}{0}{} \\
0 \\
0
\end{tabular} & $\begin{array}{l}12 \\
2 \\
8 \\
0 \\
0\end{array}$ & $\begin{array}{c}\mathscr{O} \\
\stackrel{0}{0} \\
\dot{0}\end{array}$ & 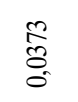 & $\begin{array}{l}\stackrel{2}{n} \\
0 \\
0 \\
0\end{array}$ & $\begin{array}{l}\hat{0} \\
8 \\
0 \\
0\end{array}$ & $\underset{\tilde{g}}{\tilde{g}}$ & $\begin{array}{c}0 \\
\infty \\
\tilde{\delta} \\
0\end{array}$ & 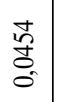 & 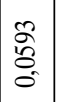 & $\underset{0}{\infty}$ & $\begin{array}{l}8 \\
0 \\
0 \\
0\end{array}$ \\
\hline$\dot{\Sigma}$ & 恶 & 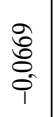 & 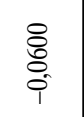 & $\begin{array}{l}\hat{8} \\
\stackrel{0}{0} \\
\hat{1}\end{array}$ & $\left|\begin{array}{c}0 \\
0 \\
0 \\
0 \\
0 \\
1\end{array}\right|$ & $\begin{array}{l}8 \\
\stackrel{0}{0} \\
0 \\
0 \\
1\end{array}$ & 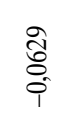 & 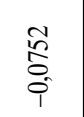 & $\begin{array}{l} \pm \\
\hat{2} \\
0 \\
0 \\
0\end{array}$ & 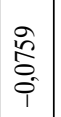 & $\begin{array}{l}\stackrel{0}{0} \\
0 \\
0 \\
i\end{array}$ & $\begin{array}{l}8 \\
0 \\
0 \\
0 \\
i \\
1\end{array}$ & $\begin{array}{l}\overrightarrow{0} \\
\stackrel{0}{0} \\
\stackrel{0}{1}\end{array}$ & 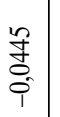 & 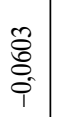 \\
\hline 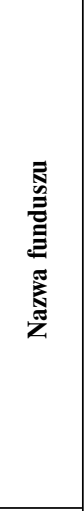 & & 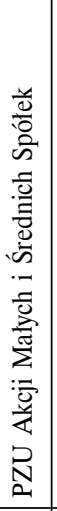 & 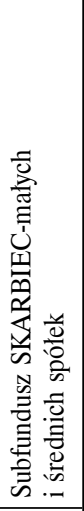 & 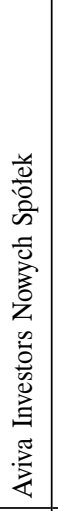 & 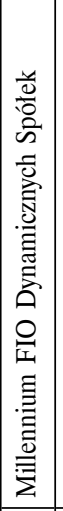 & 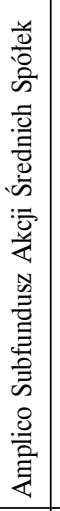 & 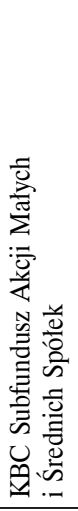 & 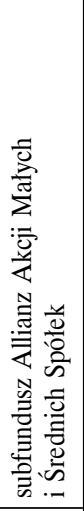 & 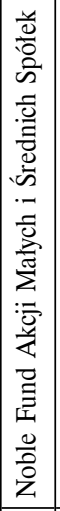 & 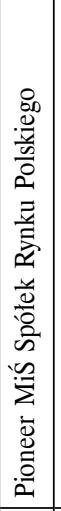 & 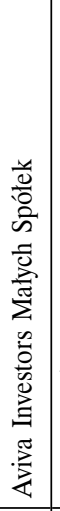 & 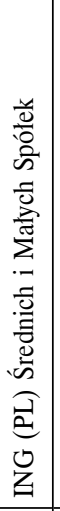 & 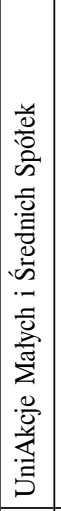 & 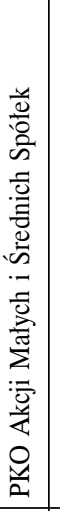 & 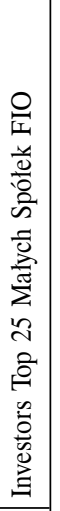 \\
\hline$\dot{3}$ & & $\dot{\sim}$ & $\dot{\sim}$ & ત่ & $\ddot{\lambda}$ & $\stackrel{\sim}{\sim}$ & 2 & $\ddot{\sim}$ & $\vec{\sim}$ & $\stackrel{\sim}{i}$ & ते & $\dot{\rho}$ & $\dot{m}$ & ત่ & $\dot{m}$ \\
\hline
\end{tabular}


Rysunek 10.1. Profil ryzyko całkowite - dochód analizowanych funduszy inwestycyjnych w okresie 27.03.2009-25.03.2014*

odchylenie stand. stopy zwrotu

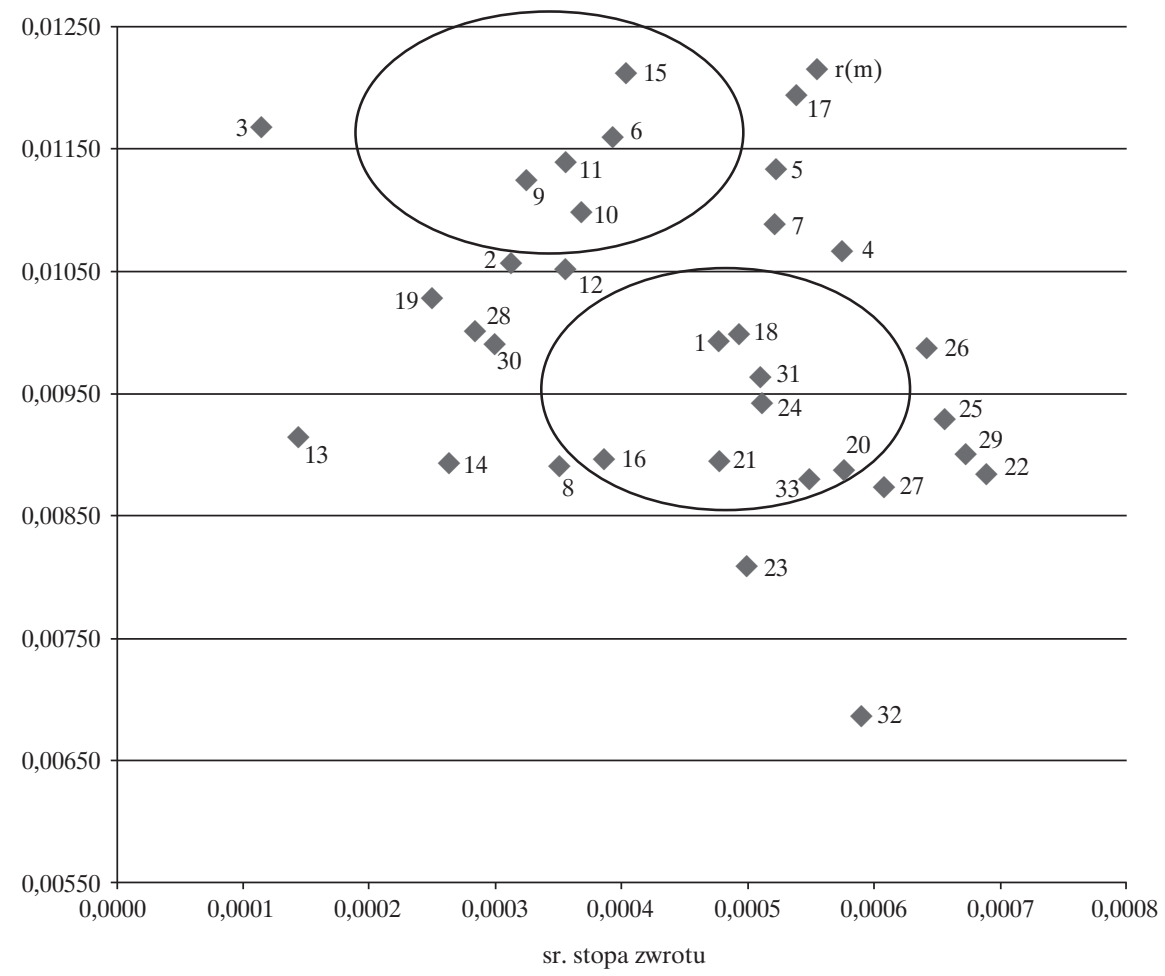

* numeracja funduszy jak w tabeli 10.1.

Źródło: opracowanie własne.

Znaczna część badanych funduszy uniwersalnych osiągała stopę zwrotu zbliżoną do stopy zwrotu z portfela rynkowego, reprezentowanego przez stopę zwrotu z indeksu WIG $(r(m)$ ), przy znacznie mniejszym ryzyku (na przykład KBC Subfundusz AKCYJNY, UniKorona Akcje, Noble Fund Akcji, Aviva Investors Polskich Akcji). Prawie wszystkie analizowane fundusze akcji małych i średnich spółek osiagały stopy zwrotu wyższe (lub nieznacznie niższe) niż stopy z portfela rynkowego, jednocześnie cechowały się one niższym ryzykiem całkowitym (z wyjątkiem ING Średnich i Małych Spółek, Pioneer MiŚ Spółek Rynku Polskiego). Szczególnie niekorzystnie kształtowała się relacja stopy zwrotu do ponoszonego ryzyka całkowitego w przypadku: Pioneer Akcji Polskich, AXA FIO Subfundusz Akcji, ING Selektywny (wysoka zmienność stóp zwrotu przy niskim poziomie dziennej stopy zwrotu). 
Jednocześnie, PKO Akcji Małych i Średnich Spółek osiągnął stopę zwrotu wyższą $\mathrm{w}$ relacji do portfela rynkowego przy najniższym poziomie ryzyka całkowitego. Uzyskane wyniki częściowo potwierdzają przypuszczenie o występowaniu ponadprzeciętnej stopy zwrotu w przypadku funduszy akcji małych i średnich spółek. Jednocześnie ta grupa funduszy cechowała się generalnie niższym poziomem zmienności stóp zwrotu, co częściowo może być związane z generalnie niższą płynnością akcji takich spółek.

$\mathrm{Na}$ kolejnym etapie badań analizie poddano współczynnik beta analizowanych dwóch grup funduszy inwestycyjnych (tabela 10.2).

Tabela 10.2. Współczynniki beta badanych funduszy inwestycyjnych

\begin{tabular}{|c|c|c|c|c|c|c|}
\hline Lp. & Nazwa funduszu & $\begin{array}{c}27.03 .2009- \\
25.03 .2014\end{array}$ & 2010 & 2011 & 2012 & 2013 \\
\hline & \multicolumn{6}{|c|}{ Fundusze małych i średnich spółek } \\
\hline 1. & PZU Akcji Małych i Średnich Spółek & 0,119 & 0,604 & 0,684 & 0,621 & 0,693 \\
\hline 2. & $\begin{array}{l}\text { Subfundusz SKARBIEC-małych } \\
\text { i średnich spółek }\end{array}$ & 0,167 & 0,510 & 0,713 & 0,631 & 0,661 \\
\hline 3. & Aviva Investors Nowych Spółek & 0,025 & 0,609 & $-0,030$ & 0,019 & 0,546 \\
\hline 4. & Millennium FIO Dynamicznych Spółek & 0,111 & 0,557 & 0,627 & 0,576 & 0,588 \\
\hline 5. & $\begin{array}{l}\text { Amplico Subfundusz Akcji Średnich } \\
\text { Spółek }\end{array}$ & 0,144 & 0,568 & 0,714 & 0,625 & 0,762 \\
\hline 6. & $\begin{array}{l}\text { KBC Subfundusz Akcji Małych i Średnich } \\
\text { Spółek }\end{array}$ & 0,164 & 0,006 & 0,018 & $-0,002$ & 0,728 \\
\hline 7. & Allianz Akcji Małych i Średnich Spółek & 0,087 & 0,208 & 0,955 & 0,151 & 0,612 \\
\hline 8. & $\begin{array}{l}\text { Noble Fund Akcji Małych i Średnich } \\
\text { Spółek }\end{array}$ & 0,564 & 0,545 & 0,731 & 0,590 & 0,608 \\
\hline 9. & Pioneer MiŚ Spółek Rynku Polskiego & 0,701 & 0,580 & 0,817 & 0,640 & 0,740 \\
\hline 10. & Aviva Investors Małych Spółek & 0,615 & 0,579 & 0,679 & 0,612 & 0,566 \\
\hline 11. & ING (PL) Średnich i Małych Spółek & 0,698 & 0,652 & 0,802 & 0,644 & 0,713 \\
\hline 12. & UniAkcje Małych i Średnich Spółek & 0,373 & 0,404 & 0,413 & 0,250 & 0,340 \\
\hline 13. & PKO Akcji Małych i Średnich Spółek & 0,472 & 0,503 & 0,550 & 0,451 & 0,474 \\
\hline \multirow[t]{2}{*}{14.} & Investors Top 25 Małych Spółek FIO & 0,561 & 0,546 & 0,686 & 0,552 & 0,491 \\
\hline & \multicolumn{6}{|c|}{ Fundusze akcyjne uniwersalne } \\
\hline 15. & LM Parasol FIO Subfundusz & 0,795 & 0,809 & 0,866 & 0,792 & 0,799 \\
\hline 16. & Arka BZ WBK Akcji & 0,815 & 0,833 & 0,847 & 0,851 & 0,846 \\
\hline 17. & Pioneer Akcji Polskich & 0,924 & 0,825 & 0,987 & 0,939 & 0,931 \\
\hline
\end{tabular}


cd. Tabeli $\mathbf{1 0 . 2}$

\begin{tabular}{|c|l|c|c|c|c|c|}
\hline Lp. & \multicolumn{1}{|c|}{ Nazwa funduszu } & $\begin{array}{c}\mathbf{2 7 . 0 3 . 2 0 0 9 -} \\
\mathbf{2 5 . 0 3 . 2 0 1 4}\end{array}$ & $\mathbf{2 0 1 0}$ & $\mathbf{2 0 1 1}$ & $\mathbf{2 0 1 2}$ & $\mathbf{2 0 1 3}$ \\
\hline 18. & Aviva Investors Polskich Akcji & 0,832 & 0,867 & 0,872 & 0,697 & 0,716 \\
\hline 19. & UniKorona Akcje & 0,555 & 0,695 & 0,484 & 0,486 & 0,531 \\
\hline 20. & ING (PL) Akcji & 0,942 & 1,012 & 0,987 & 0,917 & 0,916 \\
\hline 21. & Noble Fund Akcji & 0,751 & 0,947 & 0,913 & 0,798 & 0,191 \\
\hline 22. & PKO Akcji - FIO & 0,809 & 0,802 & 0,808 & 0,795 & 0,700 \\
\hline 23. & PZU Akcji KRAKOWIAK & 1,026 & 0,883 & 0,902 & 0,890 & 0,968 \\
\hline 24. & BPH Subfundusz Akcji & 1,023 & 0,879 & 0,924 & 0,932 & 0,877 \\
\hline 25. & Subfundusz Akcji SKARBIEC-AKCJA & 0,922 & 0,940 & 0,869 & 1,020 & 0,999 \\
\hline 26. & Millenium FIO Akcji & 0,929 & 0,932 & 0,859 & 0,863 & 0,822 \\
\hline 27. & AXA FIO Subfundusz Akcji & 0,659 & 0,474 & 0,795 & 0,615 & 0,832 \\
\hline 28. & Subfundusz Alianz Akcji & 0,898 & 1,066 & 0,989 & 0,944 & 0,484 \\
\hline 29. & Investor Akcji Dużych Spółek FIO & 0,810 & 0,819 & 0,809 & 0,793 & 0,690 \\
\hline 30. & PKO Akcji Plus & 1,122 & $-0,042$ & $-0,036$ & $-0,015$ & 0,941 \\
\hline 31. & KBC Subfundusz Akcyjny & 1,066 & 0,723 & 0,823 & 0,786 & 0,786 \\
\hline 32. & Credit Agricole Akcyjny FIO & 1,333 & 0,615 & 0,798 & 0,678 & 0,845 \\
\hline 33. & ING (PL) Selektywny & 0,795 & 0,809 & 0,866 & 0,792 & 0,799 \\
\hline
\end{tabular}

Źródło: opracowanie własne.

Współczynnik beta - jako miara wrażliwości stopy zwrotu na zmiany zachodzące na rynku - powszechnie jest wykorzystywany jako miara ryzyka systematycznego portfela inwestycji. Badania wykazały, że zdecydowana większość funduszy inwestujących w akcje małych i średnich spółek (9 na analizowanych 14 podmiotów) cechowała się w całym analizowanym okresie 2009-2014 niższym współczynnikiem beta w relacji do funduszy uniwersalnych, co wskazuje na niższą wrażliwość na zmiany stopy zwrotu $\mathrm{z}$ tzw. portfela rynkowego.

W przypadku tej grupy funduszy współczynnik beta należał do przedziału $[-0,03-0,955]$ w całym analizowanym okresie. Szczególnie niską wrażliwością na zmiany rynkowe w grupie funduszy małych i średnich spółek cechowały się: KBC Subfundusz Akcji Małych i Średnich Spółek (z wyjątkiem 2013 roku), Aviva Investors Nowych Spółek. W grupie funduszy uniwersalnych współczynnik beta w całym analizowanym okresie należał do przedziału [-0,042-1,333]. Relatywnie niskie w tej grupie funduszy współczynniki beta wykazały: PKO Akcji Plus, UniKorona Akcje oraz AXA FIO Subfundusz Akcji. Fundusze inwestujące w małe i średnie spółki można zatem określać w relacji do portfela rynkowego 
jako fundusze defensywne (niska wrażliwość na zmiany stopy zwrotu z portfela rynkowego), a fundusze akcji uniwersalne jako bardzie agresywne (stosunkowo wysoka wrażliwość stóp zwrotu na zmiany portfela rynkowego). Relatywnie wysoką wrażliwością na zmienność rynku wykazywały się w grupie funduszy małych i średnich spółek: Pioneer MiŚ Spółek Rynku Polskiego, ING Średnich i Małych Spółek, Allianz Akcji Małych i Średnich Spółek, naomiast w grupie funduszy uniwersalnych: Subfundusz Alianz Akcji, ING (PL) Akcji Subfundusz Akcji Skarbiec-Akcja, Pioneer Akcji Polskich, Credit Agricole Akcyjny FIO.

Biorąc pod uwagę przekrój czasowy, należy zauważyć, że w 2013 roku (polepszenie koniunktury giełdowej) poziom współczynnika beta wzrósł w obydwu analizowanych grupach funduszy inwestycyjnych. Uzyskane wyniki badań wskazują na znaczną zmienność współczynników beta w grupie funduszy małych i średnich spółek w przypadku: Allianz Akcji Małych i Średnich Spółek, Aviva Investors Nowych Spółek, KBC Subfundusz Akcji Małych i Średnich Spółek oraz w grupie funduszy uniwersalnych w: PKO Akcji Plus, Noble Fund Akcji, ING Akcji. Zmienność współczynnika beta w czasie związana jest $\mathrm{z}$ doborem instrumentów do portfela.

Generalnie w przypadku korzystnej koniunktury giełdowej zarządzający dążą do podwyższenia współczynnika beta portfela poprzez odpowiednią selekcje instrumentów finansowych, zwiększając udział tzw. instrumentów agresywnych. Największą stabilnością współczynnika beta cechowały się w grupie funduszy małych i średnich spółek: Aviva Investors Małych Spółek i PKO Akcji Małych i Średnich Spółek, w grupie funduszy uniwersalnych zaś: Arka BZ WBK Akcji, LM Parasol FIO Subfundusz.

Biorąc pod uwagę dochód osiągany przez fundusze inwestycyjne w relacji do ryzyka rynkowego w obydwu analizowanych grupach funduszy (rys. 10.2), można stwierdzić, że w grupie funduszy akcyjnych uniwersalnych znaczna część funduszy osiągała podobną (lub nieznacznie wyższą) do funduszy małych i średnich spółek stopę zwrotu przy relatywnie wysokim współczynniku beta, tj.: Pioneer MiŚ Spółek Rynku Polskiego, ING Średnich i Małych Spółek w porównaniu z funduszami: Subfundusz Alianz Akcji, ING Selektywny.

Natomiast w grupie funduszy akcji małych i średnich spółek przy wyższych (lub podobnych), do funduszy akcji uniwersalnych, stopach zwrotu pojawiał się relatywnie niski poziom ryzyka rynkowego, zwłaszcza: Aviva Investors Nowych Spółek, Millennium FIO Dynamicznych Spółek, KBC Subfundusz Akcji Małych i Średnich Spółek, Amplico Subfundusz Akcji Średnich Spółek, Subfundusz SKARBIEC - małych i średnich spółek. Szczególnie niekorzystna relacja stopy zwrotu do wysokości ryzyka rynkowego kształtowała się w przypadku funduszy: Pioneer Akcji Polskich i AXA FIO Subfundusz Akcji - najniższa stopa zwrotu wśród funduszy przy jednocześnie relatywnie wysokim poziomie ryzyka rynkowego. 
Rysunek 10.2. Profil ryzyko rynkowe - dochód analizowanych funduszy inwestycyjnych w okresie 27.03.2009-25.03.2014*

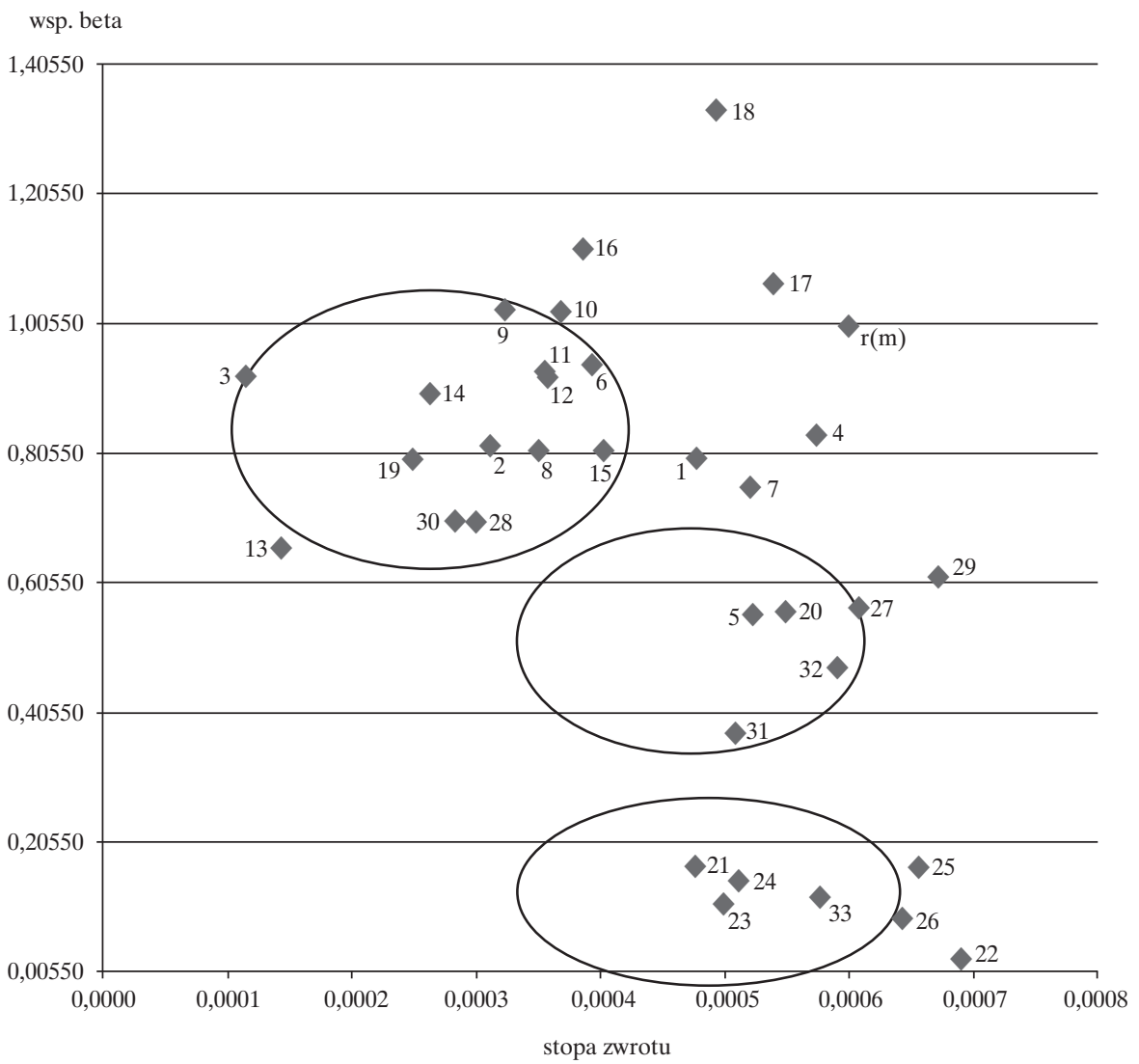

* numeracja funduszy jak w tabeli 10.1.

Źródło: opracowanie własne.

W ostatnim etapie badania oszacowano miary efektywności dla analizowanych funduszy inwestycyjnych (tabela 10.3). Przeprowadzone badania pozwalają stwierdzić, że:

- w długim horyzoncie czasowym (cały okres badawczy 27.03.2009-25.03.2014) w grupie funduszy akcji uniwersalnych znacznie mniejsza - w relacji do grupy funduszy małych i średnich spółek - liczba funduszy osiaggała premię za ryzyko całkowite wyższą niż premia dla portfela rynkowego (pogrubione wskaźniki Sharpe'a w tabeli 10.3); natomiast, w sytuacji pogorszenia koniunktury na giełdzie w latach 2011-2012 zaledwie jeden spośród funduszy akcji 
uniwersalnych i dwa spośród funduszy małych i średnich spółek osiaggały dodatnią premię za ryzyko całkowite: w 2011 roku: Noble Fund Akcji i Aviva Investors Nowych Spółek oraz subfundusz Allianz Akcji Małych i Średnich Spółek; mniejszą zaś ujemną premię za ryzyko całkowite osiągnęły w okresie dekoniunktury: w grupie funduszy akcyjnych uniwersalnych: LM Parasol FIO Subfundusz 2011 roku i Noble Fund Akcji w 2012 roku oraz w grupie funduszy akcji małych i średnich spółek: Aviva Investors Małych Spółek w 2011 roku; natomiast w okresie dobrej koniunktury giełdowej w 2013 roku żaden $\mathrm{z}$ funduszy małych i średnich spółek nie osiągnął premii za ryzyko całkowite wyższej niż w przypadku portfela rynkowego; natomiast w grupie funduszy akcji uniwersalnych w tym okresie wyższe wartości wskaźnika Sharpe'a osiągnęły uniwersalne fundusze akcji, to jest: Aviva Investors Polskich Akcji, ING Akcji, Noble Fund Akcji, Subfundusz Akcji SKARBIEC-AKCJA, KBC Subfundusz Akcyjny, Subfundusz Credit Agricole Akcyjny FIO;

- biorąc pod uwagę premię za ryzyko rynkowe, można uznać, że w całym okresie badawczym wysoką efektywnością w relacji do rynku cechowały się: w grupie funduszy uniwersalnych: Aviva Investors Polskich Akcji, ING Akcji oraz Noble Fund Akcji; w grupie funduszy małych i średnich spółek: PZU Akcji Małych i Średnich Spółek, Aviva Investors Nowych Spółek, KBC Subfundusz Akcji Małych i Średnich spółek, subfundusz Allianz Akcji Małych i Średnich Spółek, Aviva Investors Małych Spółek, Noble Fund Akcji Małych i Średnich Spółek, PKO Akcji Małych i Średnich Spółek; jednocześnie w okresie dekoniunktury giełdowej większą efektywnością w relacji do portfela rynkowego cechowały się w 2011 roku: LM Parasol FIO Subfundusz i Noble Fund Akcji oraz Aviva Investors Nowych Spółek i Aviva Investors Małych Spółek; natomiast w okresie korzystnej koniunktury giełdowej w 2013 roku większą efektywnością cechowały się generalnie fundusze akcji uniwersalne, na co wskazują oszacowane wskaźniki Treynora w przypadku funduszy: Aviva Investors Polskich Akcji, ING Akcji, Noble Fund Akcji, Subfundusz Akcji SKARBIEC-AKCJA, KBC Subfundusz Akcyjny, Subfundusz Credit Agricole Akcyjny FIO;

- umiejętność selekcji walorów do portfela w długim horyzoncie czasowym (cały okres badawczy) należy ocenić pozytywnie w grupie funduszy akcyjnych uniwersalnych: Aviva Investors Polskich Akcji, Noble Fund Akcji, natomiast w grupie funduszy akcji małych i średnich spółek: PZU Akcji Małych i Średnich Spólek, Aviva Investors Nowych Spółek, subfundusz Allianz Akcji Małych i Średnich Spółek, KBC Subfundusz Akcji Małych i Średnich spółek, Noble Fund Akcji Małych i Średnich Spółek, Aviva Investors Małych Spółek oraz PKO Akcji Małych i Średnich Spółek. 
Tabela 10.3. Miary efektywności badanych funduszy inwestycyjnych

\begin{tabular}{|c|c|c|c|c|}
\hline \multirow{2}{*}{ Lp. } & \multirow{2}{*}{ Nazwa funduszu } & \multicolumn{3}{|c|}{ 27.03.2009-25.03.2014 } \\
\hline & & Sharne' & Trevnora & Jenseng \\
\hline & Fundusze akcyjne uniwersalne & & & \\
\hline 1. & LM Parasol FIO Subfundusz & 0,246 & 0,042 & $-0,001$ \\
\hline 2. & Arka BZ WBK Akcji & 0,055 & 0,012 & $-0,059$ \\
\hline 3. & Pioneer Akcji Polskich & $-0,349$ & $-0,110$ & $-0,127$ \\
\hline 4. & Aviva Investors Polskich Akcji & 0,518 & 0,113 & 0,025 \\
\hline 5. & UniKorona Akcje & 0,231 & 0,041 & $-0,002$ \\
\hline 6. & ING (PL) Akcji & 0,293 & 0,062 & $-0,018$ \\
\hline 7. & Noble Fund Akcji & 0,300 & 0,057 & 0,012 \\
\hline 8. & PKO Akcji - FIO & 0,057 & 0,010 & $-0,027$ \\
\hline 9. & PZU Akcji KRAKOWIAK & $-0,005$ & $-0,001$ & $-0,045$ \\
\hline 10. & BPH Subfundusz Akcji & $-0,040$ & $-0,007$ & $-0,049$ \\
\hline 11. & Subfundusz Akcji SKARBIEC-AKCJA & $-0,005$ & $-0,001$ & $-0,040$ \\
\hline 12. & Millenium FIO Akcji & 0,030 & 0,005 & $-0,035$ \\
\hline 13. & Subfundusz Alianz Akcji & $-0,144$ & $-0,025$ & $-0,045$ \\
\hline 14. & Investor Akcji Dużych Spółek FIO & 0,027 & 0,004 & $-0,033$ \\
\hline 15. & PKO Akcji Plus & 0,128 & 0,022 & $-0,017$ \\
\hline 16. & KBC Subfundusz AKCYJNY & 0,167 & 0,027 & $-0,016$ \\
\hline 17. & Subfundusz Credit Agricole Akcyjny FIO & 0,066 & 0,011 & $-0,032$ \\
\hline \multirow[t]{2}{*}{18.} & ING (PL) Selektywny & $-0,255$ & $-0,045$ & $-0,171$ \\
\hline & \multicolumn{4}{|l|}{ Fundusze małych i średnich spółek } \\
\hline 19. & PZU Akcji Małych i Średnich Spółek & 0,274 & 0,050 & 0,009 \\
\hline 20. & $\begin{array}{l}\text { Subfundusz SKARBIEC-małych } \\
\text { i średnich spółek }\end{array}$ & 0,078 & 0,015 & $-0,028$ \\
\hline 21. & Aviva Investors Nowych Spółek & 0,308 & 0,055 & 0,015 \\
\hline 22. & Millennium FIO Dynamicznych Spółek & 0,116 & 0,022 & $-0,021$ \\
\hline 23. & Amplico Subfundusz Akcji Średnich Spółek & 0,109 & 0,019 & $-0,024$ \\
\hline 24. & $\begin{array}{l}\text { KBC Subfundusz Akcji Małych i Średnich } \\
\text { spółek }\end{array}$ & 0,292 & 0,052 & 0,012 \\
\hline 25. & $\begin{array}{l}\text { subfundusz Allianz Akcji Małych i Średnich } \\
\text { Spółek }\end{array}$ & 0,288 & 0,058 & 0,016 \\
\hline 26. & Noble Fund Akcji Małych i Średnich Spółek & 0,419 & $\mathbf{0 , 0 7 8}$ & $\mathbf{0 , 0 3 6}$ \\
\hline 27. & Pioneer MiŚ Spółek Rynku Polskiego & $-0,200$ & $-0,036$ & $-0,138$ \\
\hline 28. & Aviva Investors Małych Spółek & 0,292 & $\mathbf{0 , 0 5 1}$ & 0,009 \\
\hline 29. & ING (PL) Średnich i Małych Spółek & $-0,127$ & $-0,024$ & $-0,083$ \\
\hline 30. & UniAkcje Małych i Średnich Spółek & 0,082 & 0,015 & $-0,036$ \\
\hline 31. & PKO Akcji Małych i Średnich Spółek & $\mathbf{0 , 3 2 5}$ & 0,060 & 0,016 \\
\hline 32. & Investors Top 25 Małych Spółek FIO & 0,139 & 0,027 & $-0,020$ \\
\hline 33. & portfel rynkowy & 0,246 & 0,041 & - \\
\hline
\end{tabular}

Źródło: opracowanie własne. 
Rozdział 10. Profil ryzyko - dochód funduszy inwestycyjnych malych i średnich spótek 167

\begin{tabular}{|c|c|c|c|c|c|c|c|c|}
\hline \multicolumn{3}{|c|}{2011} & \multicolumn{3}{|c|}{2012} & \multicolumn{3}{|c|}{2013} \\
\hline \multicolumn{9}{|c|}{ Wskaźnik } \\
\hline Sharpe'a & Treynora & Jensena & Sharpe'a & Treynora & Jensena & Sharpe'a & Treynora & Jensena \\
\hline & & & & & & & & \\
\hline$-0,005$ & $-0,001$ & 0,006 & $-1,005$ & $-0,158$ & $-0,031$ & 1,890 & 0,114 & $-0,009$ \\
\hline$-0,700$ & $-0,113$ & $-0,112$ & $-1,042$ & $-0,167$ & $-0,056$ & 1,361 & 0,080 & $-0,035$ \\
\hline$-0,881$ & $-0,142$ & $-0,204$ & $-1,398$ & $-0,221$ & $-0,160$ & 1,088 & 0,059 & $-0,067$ \\
\hline$-0,089$ & $-0,014$ & $-0,008$ & $-0,729$ & $-0,117$ & $-0,001$ & 2,672 & 0,152 & 0,025 \\
\hline$-0,071$ & $-0,011$ & $-0,003$ & $-0,810$ & $-0,128$ & $-0,009$ & 2,089 & 0,110 & $-0,012$ \\
\hline$-0,180$ & $-0,029$ & $-0,023$ & $-0,973$ & $-0,153$ & $-0,040$ & 2,725 & 0,143 & 0,017 \\
\hline 0,003 & 0,000 & 0,008 & $-0,616$ & $-0,097$ & 0,018 & 2,307 & 0,129 & 0,004 \\
\hline$-0,295$ & $-0,047$ & $-0,036$ & $-0,879$ & $-0,138$ & $-0,019$ & 2,272 & 0,120 & $-0,003$ \\
\hline$-0,347$ & $-0,056$ & $-0,050$ & $-1,088$ & $-0,171$ & $-0,054$ & 1,535 & 0,086 & $-0,041$ \\
\hline$-0,465$ & $-0,076$ & $-0,064$ & $-1,071$ & $-0,170$ & $-0,058$ & 2,215 & 0,112 & $-0,006$ \\
\hline$-0,503$ & $-0,081$ & $-0,062$ & $-0,883$ & $-0,139$ & $-0,023$ & 2,593 & 0,138 & 0,013 \\
\hline$-0,219$ & $-0,035$ & $-0,027$ & $-0,988$ & $-0,155$ & $-0,038$ & 2,240 & 0,116 & $-0,007$ \\
\hline$-0,483$ & $-0,079$ & $-0,046$ & $-1,464$ & $-0,237$ & $-0,063$ & 0,608 & 0,034 & $-0,068$ \\
\hline$-0,155$ & $-0,025$ & $-0,013$ & $-0,989$ & $-0,157$ & $-0,042$ & 1,630 & 0,092 & $-0,019$ \\
\hline$-0,210$ & $-0,034$ & $-0,024$ & $-15,990$ & $-0,142$ & $-0,021$ & 1,946 & 0,111 & $-0,012$ \\
\hline$-0,172$ & $-0,028$ & $-0,019$ & $-0,852$ & $-0,135$ & $-0,025$ & 2,318 & 0,114 & $-0,004$ \\
\hline$-0,537$ & $-0,088$ & $-0,078$ & $-0,781$ & $-0,125$ & $-0,014$ & 2,466 & 0,123 & 0,005 \\
\hline$-0,461$ & $-0,074$ & $-0,089$ & $-1,920$ & $-0,310$ & $-0,209$ & 0,614 & 0,049 & $-0,107$ \\
\hline & & & & & & & & \\
\hline$-0,476$ & $-0,078$ & $-0,065$ & $-0,760$ & $-0,124$ & $-0,011$ & 1,842 & 0,159 & 0,051 \\
\hline$-0,931$ & $-0,153$ & $-0,126$ & $-1,229$ & $-0,198$ & $-0,074$ & 1,447 & 0,148 & 0,041 \\
\hline 0,047 & 0,008 & 0,023 & $-7,414$ & $-22,180$ & $-0,048$ & 1,034 & 0,095 & $-0,024$ \\
\hline$-0,639$ & $-0,106$ & $-0,102$ & $-0,961$ & $-0,156$ & $-0,042$ & 1,590 & 0,155 & 0,041 \\
\hline$-0,341$ & $-0,056$ & $-0,050$ & $-1,033$ & $-0,166$ & $-0,049$ & 1,127 & 0,092 & $-0,031$ \\
\hline$-0,333$ & $-0,055$ & $-0,048$ & $-0,705$ & $-0,113$ & $-0,002$ & 1,875 & 0,161 & 0,056 \\
\hline 0,094 & 0,016 & 0,028 & $-2,109$ & $-0,393$ & $-0,123$ & 0,824 & 0,100 & $-0,025$ \\
\hline$-0,109$ & $-0,018$ & $-0,011$ & $-0,770$ & $-0,123$ & $-0,006$ & 1,864 & 0,171 & 0,061 \\
\hline$-0,909$ & $-0,148$ & $-0,236$ & $-1,379$ & $-0,221$ & $-0,170$ & 1,647 & 0,143 & 0,025 \\
\hline$-0,011$ & $-0,002$ & 0,008 & $-0,946$ & $-0,153$ & $-0,033$ & 1,560 & 0,119 & $-0,006$ \\
\hline$-0,652$ & $-0,106$ & $-0,125$ & $-1,494$ & $-0,239$ & $-0,134$ & 1,039 & 0,093 & $-0,047$ \\
\hline$-0,634$ & $-0,106$ & $-0,129$ & $-1,118$ & $-0,180$ & $-0,066$ & 1,757 & 0,168 & 0,047 \\
\hline$-0,362$ & $-0,059$ & $-0,050$ & $-0,820$ & $-0,131$ & $-0,011$ & 1,957 & 0,176 & 0,057 \\
\hline$-0,712$ & $-0,117$ & $-0,136$ & $-0,814$ & $-0,132$ & $-0,018$ & 1,807 & 0,167 & 0,057 \\
\hline$-0,068$ & $-0,011$ & - & $-0,697$ & $-0,112$ & - & 2,297 & 0,118 & - \\
\hline
\end{tabular}




\section{Podsumowanie}

Przeprowadzone badania w zakresie efektywności i ryzyka wybranych funduszy akcyjnych małych i średnich spółek w relacji do funduszy akcji uniwersalnych pozwalają stwierdzić, że:

- zaobserwowano w przypadku funduszy małych i średnich spółek niewielką nadwyżkową stopę zwrotu przy jednocześnie relatywnie niskim poziomie ryzyka całkowitego (mierzonego odchyleniem standardowym stóp zwrotu), jak i ryzyka rynkowego (mierzonego współczynnikiem beta);

- można wyodrębnić grupę funduszy cechujących się ogólnie wyższą efektywnością w całym okresie badawczym, to jest w grupie funduszy akcji uniwersalnych: Noble Fund Akcji, ING Akcji, natomiast w grupie funduszy małych i średnich spółek: Aviva Investors Nowych Spółek, Aviva Investors Małych Spólek oraz subfundusz Allianz Akcji Małych i Średnich Spółek;

- w okresie korzystnej koniunktury giełdowej w 2013 roku większą efektywnością cechowały się generalnie fundusze akcji uniwersalne, na co wskazują oszacowane wskaźniki Sharpe'a i Treynora.

W celu wysnucia bardziej wiążących wniosków, przeprowadzone badania wymagają z pewnością rozszerzenia próby badawczej oraz horyzontu czasowego. W świetle uzyskanych wyników, pojawia się też pytanie o występowanie efektu małych i średnich spółek (i jego rozmiarów) w różnych okresach koniunktury giełdowej.

\section{Bibliografia}

Ackerlof, G.A. (1970). The Market for 'Lemons': Quality, Uncertainty and the Market Mechanism. Quarterly Journal of Economics, August, 488-500.

Banz, R. (1981). The Relationship Between Return and Market Value of Common Stocks. Journal of Financial Economics, 9 (1).

Barry, Ch.B. i Brown, S.J. (1984). Differential information and the small firm effect. Journal of Financial Economics, 13 (2), June, 283-294.

Chan, K., Louis, C., Karceski, J. i Lakonishok, J. (2000). New paradigm or same old hype in equity investing?. Financial Analysts Journal, 56, 23-36.

Commission moves to enhance business transparency on social and environmental matters, European Commission - IP/13/330 16/04/2013.

Czekaj, J., Woś, M. i Żarnowski, J. (2001). Efektywność giełdowego rynku akcji w Polsce $z$ perspektywy dziesięciolecia. Warszawa: WN PWN.

Davis, J.L. (2001). Mutual Fund Performance and Manager Style. Financial Analysts Journal, January/February, 57(1), http://dx.doi.org/10.2469/faj.v57.n1.2416.

Elton, E.J. i Gruber, M.J. (1998). Nowoczesna teoria portfelowa i analiza papierów wartościowych. Warszawa: WIG Press. 
European Commission proposes ESG disclosure for large companies, April 17, 2013. Podano z: http://ec.europa.eu/internal_market/accounting/non-financial_reporting/index_en.htm.

Fama, E.F. (1970). Efficient Capital Markets: A Review of Theory and Empirical Work. Journal of Finance, May, 373-417.

Fama, E F. (1991). Efficient Capital Markets: II. Journal of Finance, 1575-1617.

Francis, J.C. (2000). Inwestycje. Analiza i zarzadzanie. Warszawa: WIG Press.

French, K.R. (1980). Stock Returns and Weekend Effect, Journal of Financial Economics, 8.

Gorman, L. (203). Conditional performance, portfolio rebalancing, and momentum of smallcap mutual funds, Review of Financial Economics, 12 (3), 287-300.

Harris, L. (1986). A Transaction Data Study of Weekly and Intradaily Patterns in Stock Returns, Journal of Financial Economics, 16.

Haugen, R. i Lakonishok, J. (1988). The Incredible January Effect. Homewood: Dow-Jones Irwin.

Haugen, R.A. (1996). Teoria nowoczesnego inwestowania. Warszawa: WIG Press.

Horowitz, J.L., Loughran, T. i Savin, N.E. (2000). Three Analyses of the Firm Size Premium. Journal of Empirical Finance, 7, 143-153.

Jajuga, K. i Jajuga, T. (2009). Inwestycje. Warszawa: WN PWN.

Jajuga, K. (2007). Zarzadzanie ryzykiem. Warszawa: WN PWN.

Keim, D.B. (1983). Size-Related Anomalies and Stock Return Seasonality: Further Empirical Evidence. Journal of Financial Economics, 12.

Kester, G.W. (1990). Market Timing with Small Versus Large-Firm Stocks: Potential Gains and Required Predictive Ability. Financial Analysts Journal, 46.

Lakonishok, J. i Maberly, E. (1990). The Weekend Effect: Trading Patterns of Individual an Institutional Investors. Journal of Finance, 45 (1).

Lakonishok, J. i Smidt, S. (1988). Are Seasonal Anomalies Real?: A Ninety Year Perspective. Review of Financial Studies, 1.

Lintner, J. (1965). The Valuation of Risk Assets and the Selection of Risky Investments in Stock Portfolios and Capital Budgets. The Review of Economics and Statistics, 47 (1).

Luenberger, D.G. (2003). Teoria inwestycji finansowych. Warszawa: WN PWN.

Mossin, J. (1966). Equilibrium in a Capital Market. Econometrica, 34 (4).

Reilly, F. i Brown K. (2001). Analiza inwestycji i zarzadzanie portfelem. Warszawa: PWE.

Reinganum, M. (1983). The anomalous stock market behavior of small firms in January: empirical tests for tax-loss selling effects. Journal of Financial Economics, 12, 89-104.

Reinganum, M. (1983). Portfolio Strategies Based on Market Capitalization. Journal of Portfolio Management, 9 (2), 29-36.

Salamaga, M. (2009). Badanie podobieństwa strategii inwestycyjnych funduszy małych i średnich spółek w Polsce. W: K. Jajuga, M. Walesiak (red.). Klasyfikacja i analiza danych - teoria i zastosowania. Taksonomia 16, (47), 157-164. Wrocław: Wydawnictwo Uniwersytetu Ekonomicznego we Wrocławiu.

Salamaga, M. (2009). Próba oceny efektywności funduszy inwestycyjnych małych i średnich spółek w Polsce. W: J. Pociecha (red.). Współczesne problemy statystyki, ekonometrii i matematyki stosowanej. Studia i Prace Uniwersytetu Ekonomicznego w Krakowie, 3, 181-192. Kraków: Wydawnictwo Uniwersytetu Ekonomicznego w Krakowie.

Sharpe, W.F. (1964). Capital Asset Prices: A Theory of Market Equilibrium under Conditions of Risk. The Journal of Finance, 19 (3).

Tarczyński, W., Witkowska, D. i Kompa, K. (2013). Wspótczynnik beta. Teoria i praktyka. Warszawa: Pielaszek Research. 
Witkowska, D. (2009). Efektywność wybranych funduszy akcyjnych w latach 2005-2007. Zeszyty Naukowe Szkoty Gtównej Gospodarstwa Wiejskiego w Warszawie Ekonomika i Organizacja Gospodarki Żywnościowej, 74. 


\section{Rozdział 11}

\section{Kadry stoją za sukcesem polskiej bankowości*}

Grażyna Raszkowska: Ta rewolucja już się dzieje - bank kojarzony przez wieki $z$ mitym szelestem banknotów, dyskretnym i nobliwym finansista, bioracym $w$ dobre ręce nasze oszczędności czy aktywa - można zobaczyć już tylko $w$ filmach. Obecnie coraz częściej to po prostu smartfon $z$ aplikacja $i$ gtosem automatycznego robota IGORA, który dzięki określonym algorytmom zweryfikuje stan naszego konta, wyda decyzję kredytowa i przeleje nam pieniqdze. A to tylko przystowiowy czubek góry lodowej - za ta cyfrowa przemiana ida kolejne zmiany dotyczace potrzeb kadrowych.

Alojzy Z. Nowak: Moim zdaniem, oceniając polskie banki w ostatnich dekadach XXI wieku nie można myśleć tylko o ich zarządach, ale i całych zespołach pracujących w strukturach danej instytucji.

Grażyna Raszkowska: Czyli o sukcesie polskiej bankowości zdecydowaty nowe kadry?

Alojzy Z. Nowak: Tak, do bankowości szli od dwudziestu - trzydziestu lat właściwie najlepsi ludzie kończący polskie uczelnie. To były osoby, które miały doskonałe wyniki na swoich kierunkach - i to nie tylko związanych z finansami, ale na przykład na Uniwersytecie Warszawskim studiowali matematykę, fizykę, chemię, absolwenci szczycący się bardzo dobrymi doktoratami.

Ich późniejsza przygoda z bankowością miała najczęściej prostą przyczynę - merkantylną - to była nowa, rozwijająca się dziedzina i banki płaciły bardzo dobrze. Co najważniejsze, ci ludzie nie zniknęli, oni nadal pracują w bankowości, wszak to oni przygotowali całe zaplecze, ten tzw. backup, bardzo dobrze funkcjonujący i pracujący.

Są też tzw. frontmeni - osoby, które ukończyły studia ekonomiczne, czy zarządzania - znają języki obce, są otwarci na świat, na zmiany. Na wyzwania

\footnotetext{
Fragmenty wywiadu pt. Czy roboty zastapia finansistów $w$ bankach? Wywiad przeprowadziła redaktor Grażyna Raszkowska. Gazeta Bankowa z 19 lipca 2019 roku.
} 
technologiczne. Choć, być może teraz już wyprzedzają nas Chiny, jeśli chodzi o płatności. To co mnie najbardziej zaskoczyło, to fakt, że nawet w małych chińskich miejscowościach nie używa się nie tylko gotówki, ale i kart kredytowych.

Grażyna Raszkowska: Czy tylko kadry zdecydowaty o sukcesie polskiej bankowości?

Alojzy Z. Nowak: Na pewno odgrywają one kluczową rolę, ale bardzo duże znaczenie miała również polityka pieniężna prowadzona przez Narodowy Bank Polski, która nie pozwoliła, aby banki były aż tak bardzo zaangażowane w ryzykowne operacje finansowe. Dzięki temu banki może nie zarabiały dużych pieniędzy, ale gwarantowały większe bezpieczeństwo i z perspektywy czasu można powiedzieć, że prowadzono trafną i skuteczną politykę makroostrożnościową.

Grażyna Raszkowska: Jakich specjalistów potrzebuje polska bankowość. Czy tylko ekonomistów i finansistów?

Alojzy Z. Nowak: Wydaje mi się, że stawianie tylko na takie kryteria zawodowe - to już przeszłość. Przede wszystkim instytucje finansowe muszą postawić na kadry o wysokiej etyce i morale. Te cechy w bankowości szczególnie się liczą. Ale ważna jest również odpowiedzialność i to nie tylko za instytucje finansowe, ale i podmioty gospodarcze $\mathrm{z}$ nimi kooperujące.

Warto też dodać, że jeśli patrzymy teraz na osoby, które otrzymują nagrody Nobla z ekonomii, to widzimy osobistości zajmujące się filozofią, ekonomią behawioralną, dysponujący wszechstronną wiedzą łączącą psychologię, ekonomię i zarządzanie.

I to jest kierunek, w którym podążają też banki w zakresie pozyskiwania kadr, choć oczywiście coraz mniej futurystycznie wygląda perspektywa, że jednak człowieka w bankowości zastąpi lub uzupełni robot, czy sztuczna inteligencja. I to się już dzieje - z rozmaitych rozwiązań innowacyjnych korzystają polskie banki i instytucje ubezpieczeniowe. Na przykład w PZU pytania będzie zadawał robot IGOR. Dowie się od nas o sytuacji wypadkowej, ustali wysokość odszkodowania i przeleje nam pieniądze.

Grażyna Raszkowska: To może oznaczać, że banki i instytucje finansowe będq potrzebowaty zupetnie innych ludzi?

Alojzy Z. Nowak: Tak, wszystko do tego zmierza. Bo jeśli będziemy mieli do czynienia z coraz większą automatyzacją, to żeby tego naszego robota IGORA zaprogramować, musimy zatrudnić programistów, matematyków, fizyków i to 
pracujących razem, zespołowo. Bez wątpienia w zespole przydadzą się też ludzie od nauk społecznych, wyjaśniający zachowania klienta.

Można sobie wyobrazić, że w tej strukturze bankowej pojawi się drugie piętro, przygotowujące produkty finansowe. I też byłoby dobrze, żeby przygotowujące je zespoły łączyły wiedzę ekonomiczną z doświadczeniem $\mathrm{z}$ zakresu zarządzania, finansów, marketingu. Ich zadaniem byłoby przygotowanie produktów, które sprzedawałby nasz przysłowiowy robot IGOR.

Grażyna Raszkowska: Czyli banki nie będa już tylko stricte instytucjami finansowymi, ale przedsiębiorstwami technologicznymi „z licencja na bankowość?

Alojzy Z. Nowak: Tak, gdyż w bankach pojawi się kolejna grupa pracowników, których zadaniem będzie, przy wspomaganiu technologii cyfrowej, sprawne i kompetentne przygotowanie produktów finansujących nowe przedsięwzięcia gospodarcze. Można bowiem przypuszczać, że gospodarka będzie się nadal rozwijać, będą powstawać nowatorskie inicjatywy biznesowe, inwestycyjne, i ktoś je musi oceniać. A to oznacza, że takie zespoły powinny składać się nie tylko z ekonomistów, ale i inżynierów, programistów - specjalistów z różnych branż, którzy potrafią zweryfikować i wycenić pomysły biznesowe pod kątem merytorycznym. Jest tu także nowa rola dla zarządów, które odpowiadają za jakość procesów decyzyjnych.

I wydaje mi się, że te nieuniknione przemiany dotyczą nie tylko dużych instytucji finansowych, ale i mniejszych podmiotów, na przykład banków spółdzielczych.

Grażyna Raszkowska: Co banki powinny zmienić, albo zrobić, aby przyciagnać do siebie specjalistów od najnowszych technologii, tak bardzo potrzebnych tym instytucjom?

Alojzy Z. Nowak: Sądzę, że najbardziej kreatywnych pracowników można znaleźć w firmach technologicznych, w fintechach. Dlatego tak ważne jest, aby ściągnąć stamtąd specjalistów, gdyż właśnie oni potrafią najbardziej ocenić wartość nowych projektów i ryzyko z nimi związane. Bez ich wiedzy, konserwatywne podejście pracowników banków może blokować rozwój tych najbardziej innowacyjnych i kreatywnych przedsięwzięć. Ale oczywiście sama kreatywność w instytucjach finansowych, bez koniecznego nadzoru, może też w skrajnym przypadku doprowadzić do powtórki kryzysu z 2008 roku, gdzie tzw. innowacyjne rozwiązania finansowe oferowane klientom banków, doprowadziły cały system do wielkiego kryzysu. 
Grażyna Raszkowska: Jaka jest więc rola uczelni ekonomicznych $w$ ksztatceniu kadr dla bankowości, dysponujących tymi cechami - nakierowanych na nowoczesność, ale z pewna domieszka konserwatyzmu?

Alojzy Z. Nowak: Na szczęście nauka opiera się na pewnych standardach - dotyczących przede wszystkim wiedzy finansowej, w tym księgowości, rachunkowości, wyceny zysków, ryzyk itd., stosowania metod marketingowych. Uniwersytet powinien jednak uczyć czegoś więcej - przewidywania i rozumienia trendów kształtujących przyszłość. Powinien kształcić ludzi otwartych na nowe wizje, nie bojących się nowych rozwiązań. Swego rodzaju wizjonerów, nowatorów.

Wydział Zarządzania Uniwersytetu Warszawskiego (A.Z. Nowak do września 2020 roku pełnił funkcję dziekana - red.) też musiał dostosować się do rynku, uczymy na nim nie tylko zarządzenia, ale na drugim kierunku - finansów, ubezpieczeń i bankowości. I na tym ostatnim kierunku - bankowości wychodzimy naprzeciw potrzebom polskiego i europejskiego rynku finansowego.

W Międzynarodowym Centrum Zarządzania kształcimy osoby, które odniosły już sukces - są albo dyrektorami w ministerstwach, albo członkami zarządów dużych firm. Mamy już ponad 1000 absolwentów Centrum, którzy współpracują z uczelnią, kilku z nich zasiada we władzach Wydziału Zarządzania. Ponadto, wielu $\mathrm{z}$ nich ma dobrze prosperujące firmy i utrzymuje kontakty z kolegami z Wydziału, tworząc bardzo ciekawą środowiskową biosferę, podobnie jak na wielu światowych uczelniach. 
Zgadzam się z opinią Wydawcy recenzowanej książki, że jedną z istotnych jej zalet są zaprezentowane w niej bardzo wyraziste poglądy Autora na tematy nurtujące dziśs środowisko ekonomistów i badaczy społecznych. Lektura tej publikacji daje też możliwość oceny poglądów i analiz naukowych Profesora Alojzego Z. Nowaka w szczególności w odniesieniu do dylematów i wyborów rozwojowych nie tylko na poziomie krajowym, ale i globalnym.

Z recenzji wydawniczej prof. dr hab. Zofii Wysokińskiej Uniwersytet Łódzki

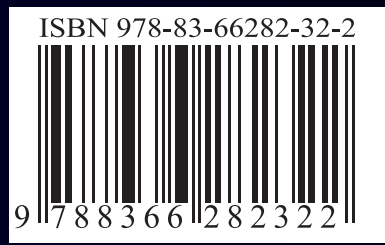

